Petronio Foscarini Neto

\title{
O distrito de Sarandira
}

mudanças e permanências na paisagem 

Petronio Foscarini Neto

\section{O distrito de Sarandira:} mudanças e permanências na paisagem

Dissertação apresentada à Faculdade de Arquitetura e Urbanismo da Universidade de São Paulo, para obtenção do grau de mestre.

Área de concentração: Paisagem e Ambiente

Orientação: Vladimir Bartalini 
E-MAIL: petroniofoscarini@gmail.com

Foscarini Neto, Petronio

F747d O distrito de Sarandira: mudanças e permanências

na paisagem / Petronio Foscarini Neto. --São Paulo, 2008.

$200 \mathrm{p}$ : il.

Dissertação (Mestrado - Área de Concentração:

Paisagem e Ambiente) - FAUUSP.

Orientador: Vladimir Bartalini

1.Paisagem - Sarandira (MG) 2.Paisagem (Aspectos ambientais)

3.Proteção ambiental 4.Planejamento territorial rural I.Título

CDU 712(815.12)S343 
Aos meus pais 


\section{Agradecimentos}

Aos muitos que contibuíram direta ou indiretamente para a realização deste trabalho.

Aos professores José Pedro de Oliveira Costa, Maria de Lourdes Zuquim e Fábio José Martins de Lima que, cada um a sua maneira, seja por suas contribuições à banca de qualificação, seja pela oportunidade dada de vivenciar profissionalmente a prática da conservação do meio ambiente, ou ainda pelos incentivos e suporte prestados, permitiram não apenas a realização deste estudo mas, de forma mais geral, a ampliação de meus conhecimentos.

Agradeço especialmente ao professor Vladimir Bartalini, que me aceitou como seu aluno e me orientou ao longo dos últimos três anos.

Aos familiares, aos quais também devo minhas raízes rurais, por todo o apoio.

Ao Ciro Vale, Glicio Paiva Foscarini, Carlos Jabour, Bernadete Sousa, Fatima Salimena, Artur Andriolo, José Augusto da Silva, Heliane Casarin, Sidnei Raimundo, Silvia Bellato, Rodrigo Sanches e aos moradores do distrito de Sarandira, pela solicitude: Biré e família, Beto, Chico, Dirceu de Oliveira, Cícero, Francisco, Alex, Didi, Luiz Mendes, Sr. Prudente, Luiz Fernando, Garapa, Celinho, Batista, Pontinha, Toninho, Taciano, Luiz Otávio, Marinho, Paulinho, José Maurício, Sr. Vicente, Sr. Bibi e esposa, Betinho, entre tantos outros.

Agradeço ainda à Carol Honora pela ajuda nas questões jurídicas, André Barreto pelo abstract, Raquel Portes pela editoração e Antonio Boscariol pela cartografia georeferenciada. 


\section{Resumo}

A paisagem do distrito juizforano de Sarandira, situado na Zona da Mata Mineira, guarda importantes referenciais naturais e culturais. Resquícios históricos do extinto ciclo econômico cafeeiro ainda estão presentes em sua arquitetura. Fragmentos de floresta nativa, recursos hídricos e uma fauna diversificada - todos de grande valor ecológico - também são encontrados na região. Este patrimônio mais significativo foi identificado ao longo da pesquisa, onde também frisou-se a necessidade de sua conservação. Outro aspecto crucial descrito foi o crescimento da mancha urbana de Juiz de Fora sobre suas terras, processo ainda incipiente, mas que já prenuncia drásticas transformações em sua paisagem para um futuro próximo. Fenômeno este que parece ser muito representativo das políticas públicas nacionais para as zonas rurais, onde persegue-se um modelo de urbanização a todo custo, sem levar em conta suas especificidades. Assim, situa-se a linha central de argumentação deste trabalho, defendendo-se a manutenção daquele patrimônio cada vez mais ameaçado, e sua contextualização diante do atual cenário de crise ambiental e de crescente demanda por qualidade de vida. Neste sentido, concluiu-se que a instituição de uma Área de Proteção Ambiental (APA) na região pode ser uma medida valiosa na promoção de melhorias em seus parâmetros sociais, econômicos e ambientais, ressaltando que a criação desta Unidade de Conservação da Natureza teria como objetivo a constituição de uma área piloto, orientada pelos princípios do desenvolvimento sustentável. Por fim, foram esboçadas algumas diretrizes gerais para um plano de paisagem para o distrito levando em conta aspectos ambientais, paisagísticos e aqueles referentes à legislação ambiental. 


\section{Abstract}

The region of Sarandira, a district of Juiz de Fora located in the area known as "Zona da Mata Mineira," has several important cultural and natural resources. Historical remnants of the economical cycle of coffee can still be found in the local architecture. It is also possible to find fragments of the native forest, as well as water resources and a diversified fauna, all of great ecological value. These valuable resources were recognized during the research phase of the present work, when the need for conservation also became clear. The last issue is specially true when one considers the growth of Juiz de Fora's urban area over the region studied, a process which, although only in its beginning, will most certainly cause drastic transformations in the local landscape in a near future. This uncontrolled growth may be regarded as a very representative example of the Brazilian public policy concerning the rural zones, which seeks a fixed model of urbanization without taking into account the particularities of each case. The main goal of this work is to support the protection of this endangered heritage and to fit it in the current scenario of environmental crisis and growing demand for life quality. In this context, it seems clear that the institution of an APA (similar to Protected Landscapes of IUCN) would improve the social, economical and environmental aspects of the region of Sarandira. This protected area could serve as a reference, governed by the principles of sustainable development. As a final contribution of this work, a plan for the landscape of the region studied was outlined, considering not only ecological aspects, but also the active environmental legislation. 


\section{Lista de mapas}

Mapa 01 - Zona da Mata: microrregiões--

Mapa 02 - Município de Juiz de Fora: divisão administrativa e zona urbana--

Mapa 03 - Distrito de Sarandira: principais vias de acesso--

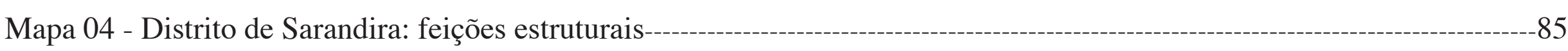

Mapa 05 - Distrito de Sarandira: altitude-

Mapa 06 - Distrito de Sarandira: perfis do terreno--

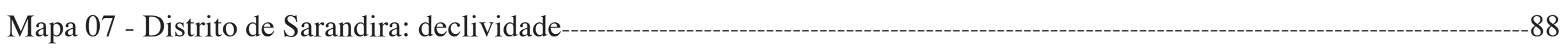

Mapa 08 - Distrito de Sarandira: hidrografia--

Mapa 09 - Distrito de Sarandira: fragmentos de floresta---_-

Mapa 10 - Distrito de Sarandira: propriedades rurais--

Mapa 11 - Distrito de Sarandira: unidades de paisagem--

Mapa 12 - Distrito de Sarandira: Áreas de Preservação Permanente--

Mapa 13 - Distrito de Sarandira: APPs e fragmentos de floresta --- 


\section{Sumário}

Introdução

Capítulo 1 - Referenciais teóricos e metodológicos

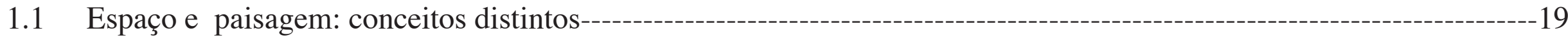

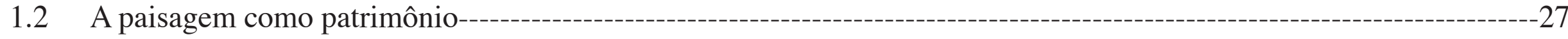

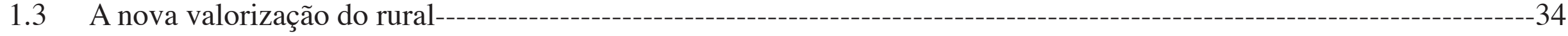

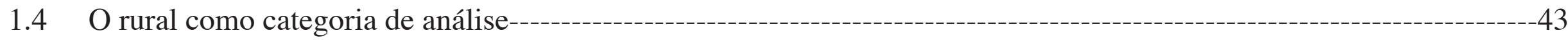

Capítulo 2 - O espaço de Sarandira: historiografia----------

2.1 Formação e evolução do distrito de Sarandira--

2.2 As atuais dinâmicas da produção espacial---on

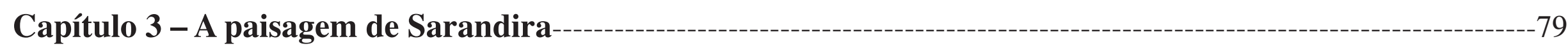

3.1 Meio biofísico--

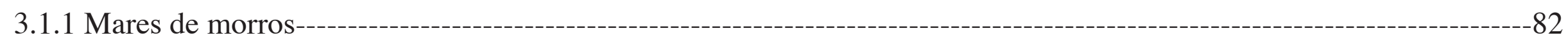

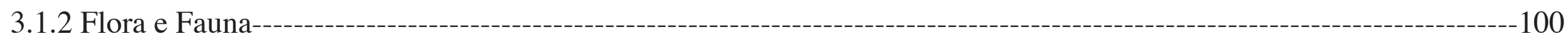




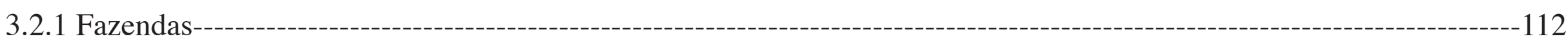

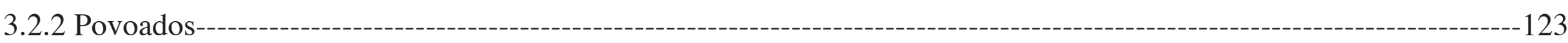

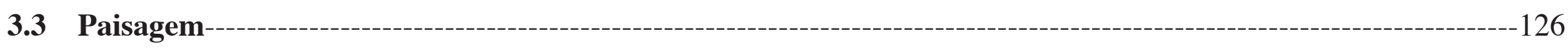

Capítulo 4 - Proteção da paisagem e do ambiente: restrições e oportunidades--------------------------------139

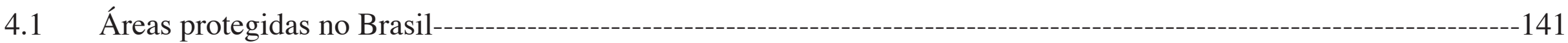

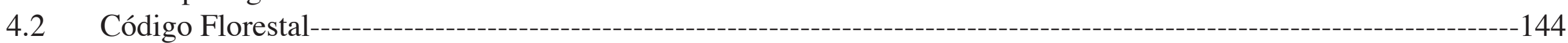

4.3 SNUC: Sistema Nacional de Unidades de Conservação--------------147

4.4 APAs: Áreas de Proteção Ambiental--

4.5 RPPNs: Reservas Particulares do Patrimônio Natural----

4.6 A criação de RPPNs em Sarandira---

4.7 A instituição de uma APA em Sarandira---

Capítulo 5 - Considerações à espacialização da APA de Sarandira--

5.1 APPs e Reservas Legais: rebatimentos na paisagem-----------171

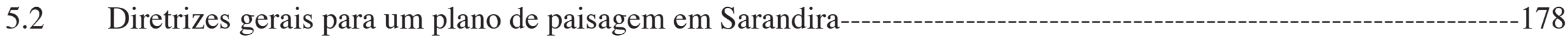

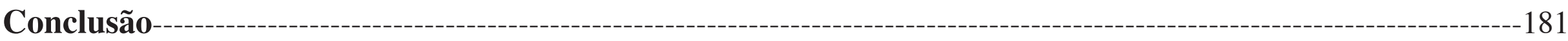

Referências Bibliográficas---- 


\section{Introdução}

As questões ligadas à proteção ambiental, no contexto mundial de crise ecológica, ganham a cada dia maior importância. Se as ações voltadas a esse fim não são novas, já que em certo sentido acompanham a própria evolução do homem, desde tempos imemoriais, foi marcadamente a partir dos impactos deflagrados pela Revolução Industrial que elas começaram a tornar-se urgentes.

Se ao longo do tempo variaram tanto os objetos quanto os meios de preservação, atualmente, um dos traços da orientação conservacionista é compatibilizar o desenvolvimento econômico com a proteção ambiental, visando preservar os recursos naturais para as futuras gerações, ainda dentro do modo de produção capitalista. Em que pesem as dificuldades, ou mesmo as impossibilidades, para a consecução destes objetivos, devido às contradições inerentes a tal sistema de produção, trata-se de uma tentativa de harmonização de duas forças, de ordens natural e econômica, que estão freqüentemente em sentidos opostos.

Se mesmo as cidades, fortemente antropizadas, são contempladas com políticas para a melhoria de sua qualidade ambiental, mediante ações que buscam o desenvolvimento sustentável, o que se tem feito pela imensa matriz rural que ainda as envolve? Lugares onde, comparativamente, ainda se expressam generosos bens naturais? Qual a possibilidade de evolução de decadentes regiões rurais, para além das atividades primárias da produção de alimentos, em repositórios da biodiversidade e de bens históricos e culturais? Em muitas dessas regiões existe um potencial latente, alimentado pela ascendente valorização 
deste patrimônio natural e cultural que abrigam.

Assim, considerando-se que este País, a despeito da visão corrente, ainda é, do ponto de vista territorial, essencialmente rural, pontuado aqui e ali por núcleos de urbanização, supõe-se que o enfrentamento de questões abrangentes, como a ambiental, também passa obrigatoriamente pelo campo.

Neste trabalho buscou-se retomar e aprofundar as discussões supra citadas, tendo como objeto de estudo um distrito rural do município de Juiz de Fora, na Zona da Mata Mineira. O foco central é sua paisagem, onde ficaram estampadas as marcas da apropriação do território, com os valores econômicos e culturais por ela produzidos, e onde também começam a se materializar importantes transformações com a chegada da urbanização, da expansão da cidade de Juiz de Fora sobre o entorno rural. Diante deste quadro, a paisagem campestre do município de Juiz de Fora é tratada aqui como um trunfo ou um diferencial a ser explorado, um patrimônio a ser conhecido e adequadamente agenciado.

O distrito de Sarandira, onde meus avós trabalharam a terra e onde ainda hoje o fazem meus tios, prestou-se como fonte de investigação não apenas pela afinidade que a ele me ligam os laços familiares, e que permitiram o acompanhamento in loco de sua evolução ao longo de anos, mas também pelo fato de que ele apresenta uma intrigante diversidade de particularidades dentro de seu próprio território, e um passado opulento e curiosamente contrastante com o presente.

Com relação a seus atributos paisagísticos, não há o caráter de exceção que normalmente caracteriza as áreas naturais merecedoras de políticas de proteção, mas nem por isso pode-se dizer que a paisagem do distrito seja desprovida de interesse próprio. Está localizado sobre uma base biofísica que se estende sem 
grandes alterações por toda a Zona da Mata, para ficarmos apenas no contexto mineiro, mas que reuniu à época do ciclo cafeeiro importantes fazendas, que nos legaram alguns notáveis remanescentes arquitetônicos datados do século XIX. Sarandira, enquanto objeto de estudo, situa-se entre esses dois extremos, os locais excepcionais e aqueles mais vulgares. Possui, portanto, elementos da paisagem notáveis que, no entanto, não se distanciam demasiadamente da realidade de suas regiões vizinhas. Essa característica é particularmente desejável quando se pretende, como aqui se fez, que algumas das questões e proposições dirigidas àquela localidade encontrem também rebatimento em seu entorno. A opção por direcionar a atenção ao interior de seus limites políticoadministrativos, como será ainda detalhado, também faz parte desta estratégia, onde o distrito pode vir a ser, inicialmente, uma zona modelo.

O trabalho foi estruturado em três partes, a saber:

Inicia-se com uma revisão bibliográfica, no capítulo 1, das idéias que sustentam as exposições feitas nos capítulos seguintes. Elas gravitam em torno dos temas paisagem, patrimônio e meio rural, focando particularmente suas interrelações.

A segunda parte é dedicada à caracterização da paisagem de Sarandira, tal como se revela no momento presente. Imprescindível foi partir, de início, no capítulo 2 , de sua historiografia, ainda que sumária e por vezes limitada pelas escassas fontes de informação. Deste recuo temporal inicial avança-se até os dias de hoje, ainda no capítulo 2, atendo-se sempre à produção do espaço naquele distrito. No capítulo 3 é tratada a materialização deste espaço, a forma como aquelas relações sociais e de produção conformaram a paisagem local. Esta foi inicialmente descrita através da decomposição de seus elementos constituintes 
mais notáveis - naturais e culturais - que foram depois reagrupados, resultando objetivamente na leitura da paisagem do distrito de Sarandira.

$\mathrm{Na}$ terceira discute-se um plano voltado à sua proteção. O capítulo 4 traça um sucinto panorama dos mecanismos nacionais de proteção da paisagem e do ambiente, sugerindo e problematizando a decretação de uma Unidade de Conservação da Natureza (UC) naquele distrito. Finalmente, no capítulo 5, são feitas algumas considerações gerais sobre o zoneamento desta UC, em que os critérios de conservação da paisagem, de adequação à legislação ambiental vigente e às premissas do desenvolvimento sustentável foram tratados conjuntamente.

Em síntese, haveria atributos naturais e culturais significativos o bastante naquela região que justificassem medidas voltadas a sua conservação? E ainda, como esses atributos, ou patrimônios, poderiam alimentar estratégias capazes de promover melhorias sociais, econômicas e ambientais para a região? Foram perguntas essenciais às quais tentou-se responder ao longo deste trabalho, dentro dos limites a que este se propõe, como uma primeira e abrangente aproximação a estes problemas complexos. 



\section{CAPÍTULO}

1 


\section{1 - Conceitos e questões}

Nestecapítuloéapresentadoo arcabouço conceitualutilizadonodesenvolvimento da pesquisa, através da revisão bibliográfica, enquanto referência genérica, dos temas que nos demais capítulos terão rebatimento específico sobre Sarandira.

O assunto tratado gira em torno do universo rural, iniciando-se pela conceituação dos termos espaço e paisagem, de fundamental importância epistemológica. Seguindo, é apresentada a consideração de paisagem como um patrimônio, um bem da coletividade a ser conservado. Posteriormente é destacada a necessidade de se olhar este espaço diante de uma nova configuração, fenômeno percebido tanto na escala local como global, orientada por fatores diversos como a importância ascendente das questões ligadas à conservação ambiental, o movimento de reação aos efeitos danosos da globalização, a crescente atenção dada à qualidade de vida e ao tempo livre pelos citadinos, e a dificuldade de reprodução da cultura rústica baseada apenas nas atividades tradicionais da agropecuária. Fatores que estarão no centro das outras duas exposições, uma delas tratando das oportunidades que se abrem a partir deste novo rural, e outra que faz a revisão do próprio significado do campo, sua abrangência e sua relação com a cidade.

Ao longo deste capítulo a abordagem utilizada na percepção e enfrentamento dos problemas referentes ao objeto deste estudo reafirmam o vasto campo de interesse presente nos estudos da paisagem e a opção por uma abordagem multidisciplinar. 


\subsection{Espaço e paisagem: conceitos distintos}

Integrantes do vocabulário de geógrafos, arquitetos, planejadores, entre outros, os termos espaço e paisagem possuem diferentes acepções, sendo diferentemente conceituados a depender das disciplinas, e assumindo novos contornos com o passar do tempo.

O tratamento que disciplinas e autores diversos dão ao espaço parece ter em comum a afirmação de sua vastidão como traço principal, característica esta também responsável pela dificuldade de sua apreensão.

Segundo LACOSTE (1995, p. 56): “até os anos sessenta os geógrafos franceses não falavam de espaço; sem dúvida, um termo muito abstrato e associado a conotações de vacuidade". Expressando problema semelhante, referindo-se aos geógrafos que buscam definir a Geografia como estudo do espaço, MORAES (2003, p. 24) afirma:

Para estes, o espaço seria passível de uma abordagem específica, a qual qualificaria a análise geográfica. Tal concepção, na verdade minoritária e pouco desenvolvida pelos geógrafos, é bastante vaga e encerra aspectos problemáticos. O principal deles incide na necessidade de explicar o que se entende por espaço - questão polêmica, ao nível da própria Filosofia.

A despeito dessa dificuldade, por conta do rigor analítico de sua metodologia, 
sua ampla aceitação no atual meio acadêmico brasileiro, e pela articulação direta e objetiva que desenvolve a partir dos conceitos de espaço e paisagem, tratados como questões nucleares nesta pesquisa, nos apoiaremos substancialmente nas definições de Milton Santos, para quem o espaço geográfico é considerado condição básica para a criação de um sistema interpretativo da Geografia (1996, p. 18), sendo também pensado como uma totalidade, um sistema de valores em permanente transformação, resultante da intrusão da sociedade nas formasobjetos componentes da paisagem (1996, p. 83).

De acordo com SANTOS (1985), para fins analíticos, o espaço pode ser dividido em elementos, divisão justificada pelo fato de os elementos disporem de extensão e de "uma estrutura interna, pela qual participam da vida do todo de que são parte" (SANTOS,1985, p. 6). Seria possível assim proceder ao estudo analítico sem o risco de perder a noção do todo. $\mathrm{O}$ autor considera como elementos do espaço: os homens, as firmas, as instituições, o meio ecológico e as infra-estruturas. Resumidamente, os homens são entendidos como força de trabalho; as firmas, pela produção de bens, e as instituições, pela produção de normas, respondem às demandas dos homens; o meio ecológico é a própria base física do trabalho humano, enquanto as infra-estruturas são este trabalho "materializado e geografizado". Ainda segundo o mesmo autor (1985), estes elementos constituintes do espaço se relacionam, não de forma bilateral, mas de modo generalizado, ou sistêmico. A variação de um elemento afeta todos os demais e, portanto, todo o sistema. O sistema que eles compõem é, por sua vez, acionado pelo modo de produção dominante num determinado contexto espaço-temporal, podendo ainda existir, no interior de um sistema, subsistemas formados por elementos correspondentes a modos de produção particulares, não dominantes. 
Essa abordagem que a princípio parte de subdivisões terá como objetivo a reconstituição do todo, permitindo compreender determinadas especificidades locais como parte integrante de um contexto global, aí residindo seu valor metodológico. Assinalada sua importância, é ainda a partir das considerações daquele autor que migramos para o segundo conceito aqui abordado.

Em sua concepção (SANTOS, 1996, p. 83), enquanto o espaço constitui um sistema de valores, a paisagem constitui um sistema material. Ela será um dos integrantes do espaço, precisamente sua materialização. Em suas palavras: "a paisagem é o conjunto de formas que, num dado momento, exprimem as heranças que representam as sucessivas relações localizadas entre o homem e a natureza". Nesta perspectiva, a paisagem é a expressão de diversos tempos, reunindo objetos do passado e do presente, constituindo um sistema material e relativamente imutável. Por outro lado, espaço é um sistema de valores, representativo do tempo presente e em permanente transformação. Da seguinte maneira, o autor (1996, p. 83) resume a diferença entre espaço e paisagem:

Paisagem e espaço não são sinônimos. A paisagem é o conjunto de formas que, num dado momento exprimem as heranças que representam as sucessivas relações localizadas entre homem e natureza. $\mathrm{O}$ espaço são essas formas mais a vida que as anima.

Ainda conforme Milton Santos (1996), dada a maior inércia das formas que compõem a paisagem, se comparadas à dinâmica a que está sujeito o espaço, é possível, pela consideração da paisagem, apreender materialmente o transcorrer 
${ }^{1}$ Mas, como o próprio autor alerta, citando $\mathrm{M}$. Bloch, não se deve impor a paisagem "a cada etapa do passado". Para Milton Santos, "o que temos diante de nós são apenas fragmentos materiais de um passado - de sucessivos passados - cuja simples recolagem não nos ajuda em muito. De fato, a paisagem permite apenas supor um passado. Se queremos interpretar cada etapa da evolução social, cumpre-nos retomar a história que esses fragmentos de diferentes idades representam juntamente com a história tal como a sociedade a escreveu de momento em momento. Assim, reconstituímos a história pretérita da paisagem, mas a função da paisagem atual nos será dada por sua confrontação com a sociedade atual." (SANTOS, 1996, p. 86).

2 No entanto, a principal referência sobre a contemplação de uma porção do território a partir de um ponto elevado, que representa de maneira consensual a experiência paisagística moderna, se dá ainda no século XIV, com a escalada do Monte Ventoux pelo poeta italiano Petrarca, e à percepcão da paisagem a partir de seu cume, em 1336. No Oriente, o olhar sensível sobre a paisagem é ainda mais antigo, e a paisagem como tema pictórico aparece na China já no século XI. da história de um determinado lugar, ou seja, tentar uma "periodização" da paisagem ${ }^{1}$.

Mas, além desta interpretação de Milton Santos, afim de pontuar brevemente a evolução histórica do significado de paisagem, bem como das formas de empreender sua leitura, convém recuarmos ainda mais no tempo.

De acordo com BESSE (2006, p. 20), em sua gênese, paisagem possuía um significado territorial e geográfico, sendo apreendida sobretudo pelo contexto “jurídico-político e topográfico", designava a "província, a pátria ou a região". Permanecia ainda atrelada ao sentido de território, uma abordagem tão concreta que era passível de uma cartografia. Apenas a partir dos séculos XVII e XVIII ${ }^{2}$ ela passa a incorporar uma forma específica de se olhar a natureza, um olhar informado pela estética e aguçado pela curiosidade, que nos influencia ainda hoje.

Essa nova apreensão da paisagem, oriunda da consciência estética da natureza, passa a ser a expressão da ordem do mundo, tendo para isto contribuído o desenvolvimento da pintura de paisagens, desde o início da modernidade e, sobretudo a partir do século XVII, que se firmava como especialização artística. No século XVIII, fortemente influenciada pelos ideais iluministas de fascínio pelo mundo natural e também marcada pelo olhar pictórico, floresce a intenção de fusão entre o sujeito e o objeto de sua contemplação, um encontro com a natureza, como aponta BESSE (2006, p. 52), fazendo menção à paisagem italiana percebida por Goethe: 
dos objetos estiverem fundidos sem se apagarem, quando a luz estiver suavizada, quando as cores puderem deslizar suavemente umas sobre as outras e se esfumarem lentamente nas distâncias azuladas.

Mas, já na segunda metade do século XIX, geógrafos como Paul Vidal de La Blache, pai da chamada escola francesa de geografia, começam a tratar a paisagem além do âmbito da estética. Esta passa a ser tomada como expressão ou fisionomia e não como representação, conduzindo a um novo tratamento epistemológico para seu estudo. Em resumo, segundo MORAES (2002, p. 71), o objeto da Geografia para aquele autor decorre da relação homem-natureza, sob o enfoque da paisagem.

Ainda conforme MORAES (2002, p. 74), La Blache repeliu os pensamentos abstratos e especulativos em nome de métodos empírico-indutivos, formulando juízos exclusivamente a partir da observação direta, limitando a explicação aos "elementos e processos visíveis". Sua abordagem teve grande influência nos geógrafos que o sucederam e, sob muitos aspectos, continua ainda atual.

Ocorre que a paisagem, contrariamente ao território, este que é profundamente atrelado ao planejamento, à organização do espaço e às representações cartográficas, é apropriada à escala humana, é vista pelo homem em seu deslocamento rotineiro, em ângulo oblíquo, limitada por acidentes naturais e artificiais, perdendo a definição e a expressividade de suas formas, cores, sons, cheiros, à medida que estes elementos se distanciam do observador. Além de percebida, ela é sentida de diferentes modos. Haverá sempre muito de abstrato, intangível e dependente da sensibilidade individual em sua apreensão, 
e os discursos científicos, diante dessas suas características simultaneamente concretas e subjetivas, estarão sempre a fazer ajustes.

Assim, aquela paisagem como realidade objetiva, na óptica positivista de La Blache, veio adquirir décadas depois um novo sentido para o geógrafo Éric Dardel. Transpondo o tratamento científico de seus predecessores à questão, ele procura resgatar as visões primeiras de mundo, anteriores a qualquer investigação ou estudo, aquela que nos fala na esfera do sensível, da fenomenologia. Segundo Dardel, os métodos científicos isoladamente não conseguem dar conta da complexidade dos lugares. As quantificações e modelizações não conseguem extrair sua verdade, já que ele se apresenta mascarado e impregnado por intencionalidades e subjetividades. Nesta abordagem filosófica, a paisagem se traduz na necessidade de circular. O horizonte será então tomado como espaço que convida à realização humana. Também Kant, em sua conceituação de paisagem, ou melhor, na determinação de seu surgimento, irá mergulhar no universo da fenomenologia. Citando Nelson Brissac Peixoto (In EMÍDIO, 2006, p. 21):

Quando então é que se tem paisagem? Kant diz que é toda vez que o espírito se desprende de uma matéria sensível para outra, conservando nesta a organização sensorial conveniente para aquela, ou pelo menos sua lembrança. A Terra vista da Lua pelos habitantes da Terra, o campo para o citadino, a cidade para o camponês. (...) O paisagista é aquele que vê as coisas de um outro ponto de vista. Há paisagem sempre que o olhar se desloca, o desenraizamento é sua condição. 
Assim também afirma WILLIAMS (1989, p. 167): "raramente uma terra em que se trabalha é uma paisagem. O próprio conceito de paisagem implica separação e observação."

Reforça-se a importância do olhar, não apenas a psicologia da visão, mas partindo mesmo de sua fisiologia, suas limitações e seu alcance. Neste sentido, segundo SANTOS (1996, p.83): "a rigor, a paisagem é apenas a porção da configuração territorial que é possível abarcar com a visão." Ou ainda para LACOSTE (2003, p. 140), citando o Dicionário Robert: "paisagem é parte de um território que a natureza oferece ao olho que a observa." Paralelamente, pode-se dizer que há também uma extensão mínima da superfície a partir da qual se pode considerar o surgimento de uma paisagem, como afirma LACOSTE (2003, p. 142), fazendo referência ao universo tático, que muito explica sobre a paisagem por ele definida ${ }^{3}$ :

Há paisagem quando a profundidade do campo de visão permite um raciocínio tático baseado na observação dos diferentes planos e acidentes do terreno e nas hipóteses quanto à maneira pela qual o inimigo é suscetível de tirar partido de sua parte, a fim de decidir pelo avanço dos movimentos que serão necessários operar nesse terreno.

No mesmo sentido, e ainda de acordo com LACOSTE, (1995, p. 74):
3 LACOSTE (2003) também refere-se à coincidência da localização dos mirantes naturais com as fortificações. O controle visual, e portanto tático, do terreno, responde pela segurança, e portanto o bem-estar, ligado à contemplação do entorno a partir desses pontos de observação.

Em sentido similar, décadas antes, Péguy também faz referência à guerra em sua abordagem de paisagem. De acordo com BESSE (2006, p. 98): "a inteligência do olhar e a rapidez da marcha, e a resolução de não retroceder, definem, para Péguy, no pensamento e na ação, a arte da boa postura. Assim, dizer que é preciso tomar uma posição, é dizer conjuntamente duas coisas: que um lugar do mundo ou do espírito deve ser conquistado numa espécie de luta, e que uma atitude deve ser adotada. (...) Experiência espiritual supremamente tática do bom posicionamento, que consiste em se aproximar das zonas sensíveis. Pensar é saber onde pensar." 
do olhar sobre a paisagem. No primeiro plano vêem-se as coisas em tamanho real e depois em escalas cada vez menores em direção ao horizonte. Isso resulta em um efeito de distanciamento, tanto do ponto de vista ótico quanto do ponto de vista psicológico. Se no primeiro plano nós somos abatidos por todas as formas visíveis da miséria, estas não são mais perceptíveis a uma certa distância, onde se estabelece uma certa "harmonia" de formas e de cores. (...) A visão estética dessas paisagens coloca o espectador em uma disposição sentimental de grande receptividade.

Traçado este breve panorama, de um tema denso e nada consensual, pode-se circunscrever os limites da aplicação dos temas espaço e paisagem neste trabalho da seguinte forma: paisagem é a materialização das interações recíprocas do homem com seu meio ambiente. É simultaneamente marca e matriz. O espaço vai além dessa materialidade, abrigando também as relações sociais.

A leitura da paisagem de Sarandira aqui desenvolvida, como é conveniente ao campo do conhecimento ao qual este trabalho se integra, e do qual paralelamente deriva boa parte de seu instrumental, se vale tanto de investigações científicas precisas, quanto de interpretações que valorizam as subjetividades. 


\subsection{A paisagem como patrimônio}

A relação histórica dos homens com a paisagem, ou a leitura que dela fazem, constitui um processo dinâmico, que evolui de forma não linear e desigual. Como o próprio desenvolvimento das sociedades e suas culturas, e mesmo a reboque destas, ela avança sob influência tanto de processos globais quanto locais, sendo ainda transformada no interior de grupos com variados níveis sócio-culturais, mediante diferentes fatores de ordem filosófica, política e religiosa, que por fim respondem pelas particularidades nas formas de ver o mundo. Como descrever essa mudança de valor, de um ambiente que aparenta ser estritamente destinado à sobrevivência do homem, para uma paisagem enquanto patrimônio - que se pretende conservar? Vejamos alguns pontos.

Em sua gênese, a eleição e preservação de objetos naturais ou manufaturados, bem como de locais carregados de valor cultural, está na origem do homem, na origem da cultura. É o mundo da cultura que marca o momento de separação entre os seres humanos e a natureza ${ }^{4}$, e é neste momento que se inaugura a apreensão sensível sobre o espaço. Desta forma, os diferentes povos vêm atribuindo importância aos mais variados elementos, seja por necessidade básica, a exemplo das regras que controlam a utilização dos recursos naturais vitais à sua sobrevivência, seja atribuindo-lhes um valor simbólico, tendo em vista não somente a perpetuação dos traços ou valores mais importantes para sua cultura, como também buscando a reafirmação de sua distinção em relação aos demais grupos. CHAUÍ (2003, p. 53) observa que, segundo Kristoff Pomian:
4 “A questão que ocupou a antropologia social em seu nascimento foi a de determinar em que momento e de que maneira os humanos se afirmaram como diferentes da Natureza, dando origem ao mundo cultural.” CHAUÍ (2003, p. 51). Mais à frente: "Cultura é, pois, a maneira pela qual os humanos se humanizam e, pelo trabalho, desnaturalizam a Natureza por meio de práticas que criam a existência social, econômica, política, religiosa, intelectual e artística." (CHAUÍ, p. $52-53)$ 
5 Sobre o poder da mídia MAZUEL (2000, p. 102) observa: "vemos, julgamos, pensamos cada vez mais pelo prisma dessas mídias. Nossos referenciais culturais nascem da "pré-digestão" que esses (instrumentos como a televisão e o computador) realizam para nós e que se tornam necessárias para entendermos um objeto cultural qualquer, até mesmo uma paisagem, por exemplo."

\begin{abstract}
Os primeiros objetos que iriam formar a idéia de patrimônio eram os semióforos (do grego semeion, sinal, e phoros, expor, carregar, brotar). (...) um semióforo é alguma coisa ou algum acontecimento cujo valor não é medido por sua materialidade e sim por sua força simbólica, por seu poder para estabelecer uma mediação entre o visível e o invisível, o sagrado e o profano, o presente e o passado, os vivos e os mortos e destinados exclusivamente à visibilidade e à contemplação porque é nisso que realizam sua significação e sua existência.
\end{abstract}

Mais recente, com a Revolução Industrial ocorre, inicialmente na Europa, uma significativa valorização dos locais menos antropizados, tanto aqueles considerados de natureza intocada quanto os espaços campestres. Ao avanço do processo de industrialização correspondia o aumento da urbanização e a explosão demográfica, tornando as paisagens naturais dotadas de beleza cênica cada vez mais distantes da realidade cotidiana dos moradores citadinos.

Saltando para a década de 1960, outro momento importante. As questões ambientais, apoiadas pelo avanço das pesquisas científicas que constatam os desequilíbrios e riscos a que o planeta estava sujeito, passam a ser discutidas no âmbito internacional. Com similar alcance, a mídia também se encarrega de reverberar essas informações e, deste ponto em diante, o tema passa a ser incorporado por grandes parcelas da sociedade, em especial nos países mais desenvolvidos 5 , imiscuindo-se também, ao menos no discurso, nos setores empresariais e nas agendas políticas.

No mesmo sentido, no Brasil, principalmente ao final da década de 1980, passam 
a ser objeto de interesse, o modo de vida, as técnicas, as construções, os costumes e crenças de grande parcela das populações indígenas, caiçaras, caipiras, incapazes de se adaptar adequadamente às mudanças impostas por aquele novo momento, profundamente marcado pela globalização, urbanização e avanço da fronteira agrícola. Ganham força as ações de proteção às manifestações culturais tradicionais, e aproximam-se os movimentos sociais e ambientalistas.

Ficam então abrigados sob a expressão "patrimônio paisagístico", os elementos significativos referentes ao meio natural e à cultura que sobre ele se desenvolve, em uma fase de intrusão das questões ambientais nas instituições responsáveis pela proteção do patrimônio cultural e, simetricamente, das questões relativas à cultura, nos órgãos de proteção do meio ambiente. Sobre este processo LANNA (2003, p. 15) observa:

(... ) a defesa do patrimônio cultural e a proteção e preservação do patrimônio natural têm, na essência, um só e mesmo ponto de partida. Dependem da relação que a sociedade com eles estabelece. Nesse sentido, podemos assumir a argumentação de Antonio A. Arantes ao afirmar que os espaços são apropriados pelos grupos humanos de acordo com concepções que lhe são próprias, transformando-se em lugares e territórios.

Segundo a autora (2003, p. 15), a década de 1980 é marcada por esse alargamento da compreensão de bem cultural, embora ainda que de forma embrionária a temática ambiental estivesse presente, no Brasil, já "nas primeiras discussões acerca do patrimônio cultural, realizadas na década de 1930, e que levaram 
6 Sphan - Serviço do Patrimônio Histórico e Artístico Nacional. à criação do Sistema de Proteção do Sphan ${ }^{6}$." Ainda conforme LANNA (2003, p. 15), em São Paulo, o Conselho de Defesa do Patrimônio Histórico, Arqueológico, Artístico e Turístico (Condephaat) participa das alterações dos critérios de valoração dos bens culturais, e surgem pedidos de tombamento voltados à conservação da memória de grupos sociais ou à memória local, bem como à manutenção da qualidade ambiental. Assim o tombamento de áreas naturais passava a ser tratado como proteção ao meio ambiente, esta cada vez mais tida como de importância crucial para a qualidade do meio urbano.

COSTA (1986) situa a emergência das questões referentes à memória coletiva e à paisagem a partir da forte preocupação mundial com as questões ambientais deflagradas na década de 1970. Nessa época há uma melhor organização das sociedades civis que lutavam pela defesa do patrimônio natural, começando a obter vitórias expressivas em sua defesa, em âmbito nacional. Ainda segundo este autor (1986, p. 24):

Tinha então sido iniciada uma transformação do entendimento do instrumento do tombamento de nosso patrimônio histórico. Essa figura, entendida inicialmente como aplicável às construções monumentais, passa a abranger a necessidade de preservação da memória de todas as classes sociais e dos conjuntos urbanos com todas suas interações. Sua aplicação à paisagem, entendida como parte da história, quer seja em seu estado natural ou trabalhada pelo homem, estava latente. A ameaça de aumento das instalações no topo do Pão de Açúcar levou o então Instituto do Patrimônio Histórico e Artístico Nacional a declarar seu tombamento, tombando também o penhasco do Corcovado. Estava aberto o caminho. 
O processo de tombamento da Serra do Mar como parque Florestal pelo Condephaat em meados dos anos 80 foi um importante marco na conservação do patrimônio para além das construções de "pedra e cal". Ao longo do referido processo, a Comissão de Conselheiros Relatores encarregada de estudar as contestações ao tombamento da Serra do Mar e de Paranapiacaba emitia um parecer $^{7}$, clareando alguns pontos importantes aqui destacados:

Item 2. Ambigüidade dos conceitos de paisagem e dos critérios utilizados.

É oportuno explicitar melhor o conceito de paisagem para não incorrer no erro de reconhecer apenas seus méritos turísticos.

De início, acentue-se ser posição universalmente aceita (T. Alibrandi e P. Ferri, I beni culturali e ambientali, Giuffrè, 1978) que o conceito de patrimônio cultural inclui tanto produtos da ação humana, quanto da natureza, já que é a apropriação social que unifica e permite entender por exemplo, artefatos e paisagens. Há, sim, diferenças operacionais importantes, pois no caso dos bens naturais os valores se referem a organismos vivos e a sistemas, colocando delicados problemas de manejo para garantir, ao mesmo tempo, os diversos usos e a disponibilidade dos valores que representam.

Assim, além de conteúdos como equilíbrio ecológico (valores ambientais), o tombamento deve levar em consideração tanto valores cognitivos (bens como suporte de informação), quanto valores formais (significação como objetos de percepção estética) e afetivos (vínculos subjetivos de comunidades na definição de identidade).
7 Processo $n^{\circ} 20868 / 79$ folhas 1,2 e 3 . Fonte: São Paulo - Secretaria de Estado da Cultura: Estudo de tombamento da Serra do Mar como Parque Florestal. 
Mais à frente (folhas 3 e 4) aquele mesmo documento informava que o Condephaat havia desenvolvido as bases para o tombamento de paisagens, contribuindo com alguns aspectos conceituais que merecem destaque, em especial quanto à dimensão simbólica da paisagem, como natureza pensada:

\begin{abstract}
A paisagem corresponde à globalidade dos componentes naturais articulados num determinado contexto espacial e temporal. Não se confunde com "recurso natural" que implica aproveitamento econômico. Assim, pode-se considerar o termo paisagem como síntese das diferentes formas de arranjo e dos diferentes processos de interação dos componentes naturais. (...)

Portanto, os poucos quadros naturais existentes são documentos vivos da evolução biológica e geológica da terra e as paisagens onde a ação humana se faz sentir mais direta e intensamente são documentos da história do homem. Toda a paisagem é um bem cultural, seja por seu valor como acervo para o conhecimento em geral, ou pelo simples fato da paisagem integrar a noção de mundo, no âmbito da consciência humana.
\end{abstract}

Também no âmbito das unidades de conservação da natureza do país, desde sua origem, além da necessidade primordial de proteção dos ecossistemas está presente a atenção à manutenção das características estéticas e, de forma mais ampla, culturais, desses espaços. O Decreto-lei $n^{\circ} 25$, de 30 de novembro de 1937, referente à proteção do patrimônio natural e ainda hoje em vigor, estabelece em seu parágrafo $2^{\circ}$ do artigo $1^{\circ}$, que são considerados bens, estando também sujeitos ao tombamento: "os monumentos naturais, bem como os 
sítios e paisagens que importe conservar e proteger pela feição notável com que tenham sido dotados pela natureza ou agenciados pela indústria humana" . BUENO (2006, p. 65) reforça a importância da conservação da paisagem enquanto "representação material de uma sociedade", cumprindo o papel de narradora da memória regional, atribuindo relevância ao passado e, desta forma, reafirmando a identidade da comunidade envolvida:

A paisagem como expressão de cultura que pode e merece ser conservada é importante pelo reconhecimento do passado, mas também como resultado de práticas culturais do presente. As relações que o ser humano estabelece com os demais e com a natureza se plasmam na paisagem e irão refletir as concepções e decisões da sociedade: sua consideração ao meio-ambiente e de como se negociam as ações nele inscritas

Insiste-se na compreensão de seu sentido mais amplo: a paisagem enquanto recursos naturais, mas também a paisagem agrícola construída durante séculos, a paisagem urbana e mesmo as mais recentes expansões urbanas por sobre o território.

Mas além disso, a manutenção de tais paisagens, singulares ou típicas transforma-se hoje em um trunfo capaz de propiciar às regiões que as possuem, a sustentabilidade de seus modos de vida, em sintonia com a recuperação e a conservação de sua qualidade ambiental. As paisagens rurais bem preservadas destacam-se neste sentido, por abrigar algumas das benesses mais valorizadas nos dias de hoje: ar puro, água limpa, cenários bucólicos e qualidade de vida.
${ }^{8}$ Como exemplo emblemático desse horizonte vasto de preocupações pode-se apontar a criação do Parque Nacional do Itatiaia, primeira Unidade de Conservação da Natureza do país, que destacava a importância dos valores cênicos da região, como mostra o decreto de sua criação, também de 1937: "Preservar para fins científicos, educacionais, paisagísticos e recreativos o seu patrimônio natural e cultural". 


\subsection{A nova valorização do rural}

${ }^{9}$ Fato verificável, por exemplo, segundo aponta GRAZIANO DA SILVA e DEL GROSSI (2000, p. 166) pelo significativo aumento da constituição de chácaras e sítios de lazer nas zonas rurais, ou ainda segundas moradias por famílias urbanas, pela de multiplicação dos pesque-pagues, das pousadas e fazenda-hotéis, e ainda pela valorização da cultura "country".

Também conforme GRAZIANO DA SILVA (2000, p. 184), apontando o início desse processo no Brasil: "Nos anos 90, o mundo rural vem sendo valorizado cada vez mais como produtor de "bens não tangíveis" tais como a paisagem e o lazer, ao lado dos tradicionais produtos agropecuários e "novos" produtos agrícolas, como a criação de animais exóticos, cultivo de flores raras, etc.
Ao longo das últimas décadas vem crescendo no país o interesse pelo meio rural: sua paisagem e o modo de vida de seus habitantes ${ }^{9}$. Pode-se citar como os maiores propulsores desse fenômeno o surgimento e difusão da "visãoecológica", aliada à valorização da identidade dos lugares face às novas tendências de sua homogeneização deflagradas pela globalização. Não obstante, outros fatores importantes são representados pela busca por uma melhor "qualidade de vida", expressão que passa a integrar de vez o vocabulário popular, e também pela ocupação do tempo livre com atividades de lazer, com destaque para a atividade turística, em suas vertentes ecológica e cultural.

De acordo com ENTRENA DURÁN (1998, apud FROEHLICH, 2000, p. 183):

Para a história moderna e sua ideologia do progresso, a cidade tem se constituído, tanto para os citadinos como para os rurícolas, numa representação de liberdade, de desenvolvimento, de civilização, um lugar que possibilita o pluralismo e uma grande variedade de estilos de vida, enquanto o meio rural fomenta o autoritarismo, o tradicionalismo, o conservadorismo e a ignorância. Parece que tal perspectiva tende a inverter-se no presente, de tal forma que hoje muitos urbanos tratam de encontrar no rural âmbitos socio-espaciais abarcáveis e idôneos para a realização de sua liberdade individual e coletiva em um mundo cada vez mais globalizado, imprevisível e inabarcável. 
MAZUEL (2000, p. 102-103) destaca o intuito das sociedades ocidentais em resgatar no meio rural suas identidades, ameaçadas pela "americanização" do mundo, bem como a importância dada à "construção de si" pautada pela criatividade e simplicidade como traços característicos da década de 1990, em conseqüência da subordinação à tecnologia e ao sucesso profissional que marcou os anos 80. LIMA (2005, In MOREIRA, 2005, p. 45) também se refere a essa nova interpretação do rural, de um passado destinado apenas à produção de bens primários, como atual palco para a satisfação de um novo indivíduo, orientado pela busca do bem estar:

Em termos de discurso, o rural não é mais o agrícola, é o campo, uma paisagem rural associada à natureza, à memória de uma sociedade camponesa, um patrimônio a preservar. Cai a lógica produtivista e vem à tona a da qualidade de vida. A nova ruralidade se torna um estilo de vida.

No mesmo sentido aponta ZUQUIM (2007, p. 128), para quem o espaço rural não é mais o mero produtor de mercadorias agrárias mas também um “ofertador de mão-de-obra, ar, água, turismo, lazer, bens de saúde" consorciando "antigas atividades agrárias com novas atividades urbanas".

Desta forma, o espaço rural passa a ser visto com grande interesse, particularmente quanto mais ele difere das paisagens cada vez mais urbanizadas nas quais vive a maioria da população. Conforme RODRIGUES (2000, p. 58), trata-se de um movimento "retrô" presente não apenas no Brasil mas "nos países centrais do 
capitalismo onde o fenômeno urbano torna-se cada vez mais expressivo e fonte geradora de estresse."

Cria-se assim, no campo, uma imagem que acena ao ideário dos citadinos como paisagem idílica, embora, como se sabe, incapaz de encobrir as muitas mazelas pelas quais passa o homem do campo, notadamente no Brasil.

Segundo VEIGA (2003), referindo-se ao surgimento dessa nova conformação do rural, houve uma época em que ao campo cabia apenas suprir a cidade com mercadorias primárias, de forma que os maiores rendimentos do processo produtivo com a transformação desses bens não ocorria na zona rural. Posteriormente, a transformação local desses bens trouxe ao campo maiores lucros, estimulando um dinamismo vital para seu desenvolvimento e atraindo o capital urbano e seus moradores, que começavam a deslocar-se com maior freqüência para o campo com fins turísticos, chegando mesmo a neles construir suas segundas residências. Passou a haver então uma grande dependência das regiões rurais mais dinâmicas em relação às rendas urbanas e, nesse sentido, as regiões dotadas de uma paisagem aprazível tornaram-se mais competitivas. Como ainda conservam traços culturais ricos e particulares e mantêm bem guardados seus ambientes naturais, tendem a atrair cada vez mais o capital urbano. Em suas palavras (2003, p. 80-82):

É imenso o leque de amenidades disponíveis nos espaços rurais. Podem variar tanto de fragmentos de natureza intocada a paisagens minuciosamente manejadas, quanto das mais antigas relíquias históricas às mais vivas tradições culturais. $\mathrm{O}$ aumento da demanda por todos esses tipos de amenidades acompanha a evolução da renda 
e do tempo livre dos habitantes urbanos, gerando novos negócios e empregos. (...) Com essa ascendente valorização das amenidades, o principal vetor de dinamismo econômico de uma região rural tende a ser o cuidado com a preservação de seu patrimônio natural e cultural. Uma circunstância que torna a consciência ambiental uma alavanca do crescimento econômico em vez de um obstáculo. Exatamente a ambição contida na utopia do desenvolvimento sustentável.

José Eli da Veiga irá chamar atenção em suas análises para o potencial contido nessas regiões comumente tachadas como representantes da parcela mais atrasada do país, muitas vezes ocupadas apenas pela agricultura familiar, destacando a forma como a pluriatividade ${ }^{10} \mathrm{e}$ a valorização de seus atributos mais significativos podem se converter no combustível capaz de alimentar sua economia, a exemplo do que vem ocorrendo nas décadas recentes no continente europeu. Segundo este autor (2003, p. 86): “As novas fontes de crescimento das áreas rurais estão principalmente ligadas a peculiaridades dos patrimônios natural e cultural, o que só reafirma o contraste entre os contextos ambientais do campo e da cidade." Ele ainda afirma que pensar a urbanização como única via para o desenvolvimento do campo é ignorar o dinamismo presente nas zonas rurais dos países que mais se desenvolvem, e que apresentam os mais elevados Índices de Desenvolvimento Humano ${ }^{11}$.

No Brasil, o fenômeno da pluriatividade teve origem com a crise da agropecuária nas décadas de 1970 e 1980 quando, como alternativa ao êxodo rural, muitos começaram a dedicar-se à complementação da renda familiar fora de suas propriedades (ELESBÃO, 2000, p. 49). Neste sentido, historicamente, o
10 Famílias pluriativas são aquelas em que ao menos um de seus membros exerce alguma atividade extra-agrícola.

$11 \mathrm{O}$ Índice de Desenvolvimento Humano (IDH) é um instrumento de avaliação utilizado pela ONU que mede o bem-estar de uma população, utilizando como parâmetros, entre outros fatores, os níveis de alfabetização, educação e expectativa de vida. 
camponês vem adequando seu trabalho em função das mudanças de cenário que se conformam nas cidades e que, por conseqüência, afetam o campo. Em determinados períodos e locais eles não encontraram meios de sobrevivência dentro de seus padrões tradicionais, indo por fim engrossar o contingente populacional dos subúrbios, com a conseqüente erosão de sua cultura. Já em outros, certamente mais raros, mantiveram-se no campo, conseguindo a reprodução de seus modos de vida e sua sobrevivência. Mas grandes oportunidades ainda são negligenciadas. Percebe-se que há um obstáculo entre as atuais oportunidades abertas aos pequenos produtores e sua pronta capacidade de se beneficiarem delas. Para alguns autores esse é um grande desafio imposto aos moradores do campo diante da atual valorização de seu território, como aponta VEIGA (2003, p. 80-81):

(...) é que as amenidades ocorrem mais em regiões que nunca estiveram entre as mais dinâmicas, não dispondo, portanto, de adequados recursos humanos e instituições. Dependem portanto, da criação de novas sinergias entre vários ramos do poder público e os mais diversos atores das organizações privadas e nãogovernamentais.

Esses locais não apenas reúnem com mais intensidade tais valores ambientais, mas também, freqüentemente, neles repousam os traços culturais mais originais. Assim, ironicamente, a manutenção de sua cultura dentro da maior integridade possível, que costuma ocorrer em muitas zonas mais conservadoras, ou menos dinâmicas, é uma das fontes potenciais para seu desenvolvimento. A 
conservação dessa cultura irá constituir-se não apenas em um poderoso fator de atração de capital mas, como afirma BUENO (2006, p. 64), em um promotor da inclusão social:

As possibilidades de utilização do recurso patrimonial paisagístico podem alavancar uma série de alternativas de ordenação territorial especialmente se considerada sua dimensão cultural para além da fruição estética e dos preceitos ecológicos. A paisagem passa a ser entendida como um elemento de construção de identidade e mesmo como um modo de promoção de cidadania (...).

Abre-se assim uma nova perspectiva de desenvolvimento para a zona rural baseada em sua singularidade, capaz de desvincular o campo do atraso e do conservadorismo a ele atribuídos, reafirmando sua identidade e sua importância, bem como atribuindo-lhe novos significados. Como afirmam (CAMPANHOLA \& GRAZIANO DA SILVA, 2000, p. 150):

Há, de certa forma, um consenso de que o desenvolvimento regional ou local constitui uma das alternativas mais viáveis para enfrentar o desafio da globalização. Embora tenda a homogeneizar produtos, padrões de consumo, hábitos e costumes em prol da eficiência e da produtividade, a globalização reforça o local, no sentido de que estimula a organização comunitária para que um lugar específico não seja excluído do processo de desenvolvimento e para que encontre o seu caminho de sustentabilidade. Em outras palavras, como o global 
fica distante do local, este se reestrutura socialmente para se fortalecer e para se viabilizar economicamente. É como se as partes fossem se diferenciando do todo para se tornarem singulares e especiais, buscando a sua independência e atendendo a seus interesses.

Essas oportunidades estão apenas começando a ser vislumbradas, por tratar-se de uma tendência, enquanto fenômeno mundial, ainda recente. Sua exploração tem se constituído em uma importante vertente da pluriatividade, trazendo grandes perspectivas, em especial para os pequenos produtores, recompensando as regiões que apresentam maior qualidade e melhores condições de conservação ambiental e paisagística. Estas, tornadas então objeto de interesse da coletividade, enquanto patrimônios, precisam ser protegidas. Embora muitas estratégias para o crescimento dessas regiões, através de sua inclusão em roteiros turísticos ou pela agregação de valor à sua produção, estejam cada vez mais sendo colocadas em prática, permanece ainda sem assistência o patrimônio constituinte da quase totalidade do mundo rural, sendo ele ainda, na maior parte das vezes, encarado como entrave ao desenvolvimento agropecuário. Alertando para a necessidade de reversão desse quadro, CAVACO (2000, p. 74) ressalva:

Uma paisagem intacta, num ambiente habitável, e a preservação da zonas habitadas tendem cada vez mais a ser consideradas um recurso importante do espaço rural. O consumo desse recurso, que representa serviços prestados pelos agricultores, nem sempre se desenrola sem conflitos, especialmente quando implica restrições à produção agrícola. A prestação de serviços no interesse da coletividade não pode efetuar-se sem custos. 
Daí a importância da criação de medidas que auxiliem o camponês no melhor aproveitamento dessas oportunidades como, por exemplo, o apoio àqueles que se dedicarem à conservação ambiental ${ }^{12}$. Também a necessidade de uma melhor adequação das políticas públicas voltadas à criação de emprego e regulamentação ambiental diante deste novo panorama. GRAZIANO DA SILVA (2000, p. 186) afirma:

(...) antes de mais nada é preciso remover o viés urbano e agrícola das atuais políticas públicas, sem o que o desenvolvimento do novo rural brasileiro estará comprometido. Uma breve revisão da literatura nos permitiu detectar um grande viés urbano nas políticas públicas para o meio rural, possivelmente fruto do esforço de industrialização perseguido há décadas. E no caso específico das políticas agrícolas, pode-se perceber um forte viés produtivista, resultado sem dúvida dos diagnósticos de insuficiência da expansão da oferta agrícola de alimentos e matérias primas para suprir as demandas dessa mesma industrialização, (...).

Mas no contexto do surgimento de um novo olhar sobre o campo, alguns estudiosos alertam para as conseqüências negativas da desmedida estetização do rural, onde seus residentes, buscando atender aos anseios dos visitantes urbanos podem acabar produzindo o espaço do simulacro, quando mal orientados por inadequadas políticas públicas. Não se deve perder de vista que, embora a pluriatividade deva ser estimulada, ela deve se dar paralelamente às atividades primárias que caracterizam o rural. Em LIMA (2005, p. 45 - 46):
12 De acordo com GRAZIANO DA SILVA (2000, p.186): “(...) a reforma de 1992 da Política Agrária Comum da Comunidade Européia representou um significativo avanço no sentido de tratar seus agricultores de maneira mais abrangente, indo além da ótica meramente produtiva. A eleição da preservação do território no seu sentido amplo (ecológico e social) e do reflorestamento como diretrizes centrais representou uma possibilidade concreta de reduzir a proteção via preços que determina o caráter eminentemente produtivista das políticas rurais da comunidade (BONETE PERALES, 1994)." 
Opondo-se ao rural agrícola homogêneo, a ruralidade torna-se o rural da diversidade; a noção de paisagem produz a estetização da ruralidade, associada diretamente à natureza. Assim, o rural aparece como paisagem natural a ser preservada e o papel do agricultor é, agora, o do jardineiro da natureza e não o de responsável pela segurança alimentar. O questionamento do modelo produtivista e de degradação ambiental muda a visão da agricultura e da ruralidade, o que vai incidir numa indiferença crescente em relação aos problemas econômicos dos agricultores.

Portanto, esta revalorização, para que obtenha êxito, precisa ser bem arquitetada. Só assim poderá alterar a face de muitas regiões hoje decadentes e miseráveis. Tal transformação tanto decorre quanto depende de uma nova leitura sobre a definição do rural, sua relevância, e ainda sua relação com a cidade. A respeito do dualismo contido em expressões como "cidade e campo", "urbano e rural" ou "rurbano", permanecem algumas dicotomias, enquanto outras vão sendo superadas. 


\subsection{0 rural como categoria de análise}

José Eli da Veiga, em Cidades Imaginárias (2003, p. 31-32), informa quanto à precariedade da visão oficial sobre o território brasileiro e seu desenvolvimento, e a necessidade de sua revisão. Chama também a atenção para um fato inusitado:

O entendimento do processo de urbanização do Brasil é atrapalhado por uma regra muito peculiar, que é única no mundo. Este País considera urbana toda sede de município (cidade) e de distrito (vila), sejam quais forem suas características.

De acordo com o mesmo autor, as distorções alimentadas por conta desse critério de avaliação são tão grandes ${ }^{13}$, que sugerem que o País teria atingido um índice de urbanização de $81,2 \%$ no ano 2000. Tentando contornar essas deturpações, muitos estudiosos passaram a adotar outra regra em suas análises, não considerando urbanos os municípios muito pequenos, com menos de 20 mil habitantes. A despeito da fácil aplicabilidade desse critério, que por si já contribui para superar a miopia da visão oficial, o autor considera necessário enriquecer essa metodologia a partir da inclusão de dois outros critérios (idem, p. 32-33):
13 Das 5.507 sedes de município brasileiros contados no ano 2000, quase 1200 possuíam menos de 2 mil habitantes, quase 4 mil deles tinham menos de 10 mil habitantes. Por fim 4.642 deles possuíam menos de 20.000 habitantes. (VEIGA, 2003, p. 32). 
14 Pesquisa intitulada Caracterização e Tendências da rede Urbana do Brasil (1999), que reuniu equipes do IBGE, Ipea e Unicamp. (VEIGA, 2003, p. 33). altas densidades demográficas, e uma parte deles pertence a regiões metropolitanas e outras aglomerações. Dois indicadores dos que melhor caracterizam o fenômeno urbano. Ou seja, para que a análise da configuração territorial possa de fato evitar a ilusão imposta pela norma legal, é preciso combinar o critério de tamanho populacional do município com pelo menos outros dois: sua densidade demográfica e sua localização. Não há habitantes mais urbanos do que os residentes nas 12 aglomerações metropolitanas, nas 37 demais aglomerações e nos outros 77 centros urbanos identificados pela pesquisa ${ }^{14}(\ldots)$. Nessa teia urbana, formada pelos 455 municípios dos três tipos de concentração, estavam 57\% da população em 2000. Esse é o Brasil inequivocamente urbano.

Assim, levada em conta a situação espacial desses municípios, sua localização, faltava então diferenciar entre os demais, um total de 5.052, aqueles que eram efetivamente rurais e os que estariam em "situação ambivalente". E aqui entra o segundo critério tido como decisivo segundo o autor (idem, p. 33-34), a densidade demográfica:

É ela que estará no âmago do chamado "índice de pressão antrópica", quando ele vier a ser construído. Isto é, o indicador que melhor refletiria as modificações do meio natural que resultam de atividades humanas. Nada pode ser mais rural do que as escassas áreas de natureza intocada, e não existem ecossistemas mais alterados pela ação humana do que as manchas ocupadas por megalópoles. É por isso que se considera a "pressão antrópica" como o melhor indicador do grau de artificialização dos ecossistemas e, portanto, do efetivo 
grau de urbanização dos territórios. (...) conclui-se que não pertencem ao Brasil indiscutivelmente urbano, nem ao Brasil essencialmente rural, $13 \%$ dos habitantes, que vivem em $10 \%$ dos municípios. E que o Brasil essencialmente rural é formado por $80 \%$ dos municípios, nos quais residem $30 \%$ dos habitantes. (...) Ao contrário da absurda regra em vigor (...) esta tipologia permite entender que só existem cidades nos 455 municípios do Brasil urbano. As sedes dos 4.485 municípios do Brasil rural são vilarejos e as sedes dos 567 municípios intermédios são vilas, das quais apenas uma parte se transformará em novas cidades.

A negação dos traços de ruralidade do país, ou sua ocultação, por nossa legislação, baseia-se na associação feita entre essas regiões e seu arcaísmo, e o intuito de superá-lo, se não na realidade, ao menos no universo estatístico. Assim, a serviço da industrialização e urbanização, foi forjada uma ideologia de desprestígio do rural.

Para alguns, o campo resiste apenas provisoriamente à urbanização sendo, portanto, juntamente com seus habitantes, meros resquícios da formação do território nacional. Outros, como MARTINS (1975), reforçam a identidade do rural - em sua unidade com a cidade - referindo-se à sua suposta separação como artificial, e decorrente do domínio da ideologia urbana e dominante.

Referindo-se às políticas governamentais brasileiras de desenvolvimento industrial a partir do início do século XX, e mais intensamente nos anos 30, com o Estado Novo, bem como entre 1950 e 1970, com a política desenvolvimentista de Kubitschek, seguida pelo "milagre econômico" do governo militar,ZUQUIM 
(2007, p. 99-100) constata:

Essas grandes transformações econômicas definiram a visão que o Brasil tem de si mesmo, de país urbanizado, que privilegiou e ainda privilegia as políticas e investimentos da economia urbana e industrial. Essa identidade de país urbano rapidamente se generalizou e adquiriu lógica própria, pela qual se valoriza o "urbano" sobre o "rural".

De qualquer forma, há neste país, territorialmente e culturalmente tão vasto e diverso, uma gama enorme de configurações entre urbanidade e ruralidade, que dificulta tanto a elaboração de políticas públicas quanto de investigações científicas abrangentes. E em relação a esta última, cabe aqui melhor conceituar o que se entende por rural.

Em linhas gerais, relaciona-se o rural ao espaço físico que comporta basicamente a produção de gêneros primários, destinados tanto ao seu abastecimento quanto das áreas urbanas. A palavra tem origem no latim rus que significa campo, de onde também deriva-se "rústico" que, pejorativamente, com o tempo também passou a designar de forma abrangente tudo aquilo que é grosseiro, incluindo seus habitantes.

Mas há outras formas de se circunscrever o espaço rural . Como adverte LIMA (2005, In MOREIRA, 2005, p. 47-48): 
De forma quase espontânea, o espaço físico ainda é o termo mais ordinariamente pensado para referir-se seja à cidade, seja ao campo. Diferentemente das interpretações correntes, F. Perroux mostrou que o espaço é mais corretamente definido por um campo de relações econômicas e outras. O espaço rural é determinado, também, por outra posição que considera o espaço como lugar de produção de coisas ou relações sociais, neste caso, ele é também um produto dessas relações sociais, valor constituído pela sociedade para traduzir suas finalidades e, por conseguinte, categoria necessária de toda análise econômica ou sociológica.

Segundo WANDERLEY (1997, p. 3, apud LIMA, 2005, p. 55):

$\mathrm{Na}$ França, por exemplo, a população rural engloba todos os habitantes das pequenas aglomerações com até 2.000 habitantes, quaisquer que sejam as atividades que exerçam. Deve-se ressaltar que a predominância de agricultores nesta população rural é um fato historicamente datado; as sociedades rurais tradicionais eram compostas por indivíduos com atividades diversas. Com a revolução industrial, os rurais não agricultores, especialmente os artesãos, são os primeiros e mais numericamente atingidos pelo êxodo para as cidades e para o trabalho industrial.

Ainda recorrendo à LIMA (2005, In MOREIRA, 2005, p. 55), no que tange à sociologia, as principais características do meio rural seriam a relação de proximidade com a natureza, ou seja, o desenvolvimento de suas ações em um 
espaço pouco edificado pelo homem, resultando em práticas e representações muito particulares do tempo, espaço, família, entre outros, e como segunda característica, as relações de sociabilidade coesa e intensa. A autora faz ainda uma outra observação importante (idem, idem, p. 56): no país, por conta da dispersão populacional no campo, não há presença efetiva do poder público, bem como a prestação de bens e serviços, "assim, o 'rural' encontra-se atrelado à cidade, como problema espacial dependente política, econômica e socialmente."

Também para SANTOS (1996, p. 65), hoje, com as transformações sofridas pela sociedade brasileira, não cabe a dicotomia rural-urbano, pois o espaço é agora preenchido por regiões agrícolas e urbanas: "Simplesmente, não mais se trataria de 'regiões rurais' e 'cidades'. Hoje as regiões agrícolas (e não rurais) contém cidades, as regiões urbanas contêm atividades rurais".

A atenção às relações que unem campo e cidade e que constituem um prérequisito indispensável para a análise dos fenômenos rurais, é também enfatizada por GRAZIANO DA SILVA e MARTINS. Citando este último (1986), SOTO (2002, p. 105) escreve: "Para ele, muitos estudos recentes sobre o mundo rural tentam separar o que o capital já unificou, ou seja, o rural e o urbano." Ainda de acordo com MARTINS (2005, p. 29):

No Brasil continuamos a pensar as populações que vivem no campo e as populações que vivem na cidade como duas humanidades divididas por um intransponível abismo. Ignoramos completamente a extensa e profunda presença da cultura camponesa e rural mesmo em metrópoles presumidas como modernas e completamente urbanas, como São Paulo. Eu me arriscaria a dizer que, pela numerosa e densa 
concentração populacional, a cidade de São Paulo é culturalmente o maior aglomerado caipira e sertanejo do Brasil. Com a diferença de que são pessoas culturalmente agrícolas empregadas em atividades não-agrícolas.

Da mesma forma, segundo SOTO (2002, p. 246-247), o mundo rural na visão de GRAZIANO DA SILVA “deixou de existir":

(...) pelo menos nos moldes em que era considerado no passado. Novas atividades caracterizam este "novo rural", atividades que ultrapassam a agricultura e a pecuária como atividades tradicionais. $\mathrm{O}$ rural não pode ser considerado isolado, pelo contrário, sua identidade passa a ser descoberta nas relações que constrói com a indústria, que lhe fornece os insumos e compra seus produtos.

Percebe-se por esses autores uma clara abordagem do meio rural atrelado ao urbano, unificados pela lógica das relações capitalistas. Nas palavras de MARTINS (1975, p.1): "o tratamento crítico que dei às minhas pesquisas permitiram-me ultrapassar o conceito limitado e limitante de "rural', de forma que os processos que investigo estão situados tanto no meio rural quanto no meio urbano." Citando SOTO (2002, p. 116): "Na visão de MARTINS (1975, p.16), o urbano e o rural constituem um 'todo articulado', dependente das relações capitalistas, que se desenvolvem como totalidade inacabada e contraditória. Assim o 'progresso urbano-industrial' não pode ser explicado separadamente 
do "atraso agropecuário",

Mas vincular à noção de totalidade as relações entre esses dois pólos não significa desconsiderar suas heterogeneidades. Ciente dessas diferenças, WANDERLEY (1997, p. 1-2. In LIMA, 2005, p. 55) afirmará que rural e urbano são espaços sociais diferentes, e que "a industrialização e a modernização da agricultura não representam qualquer "uniformização" da sociedade que atestasse o esgotamento das particularidades seja de certos espaços, seja de certos grupos sociais."

Em sentido similar, LIMA (2005, p. 46), afirma:

Enquanto na esfera científica dissemina-se a concepção de uma indiferenciação crescente entre campo e cidade, na sociedade civil predomina a visão de uma clara oposição entre ruralidade e urbanidade. O que está na base da revalorização do rural é a crise urbana. Assim como na interpretação dos anos de 1950 que apontava para a inevitável urbanização do campo, na atual há o predomínio de uma visão funcionalista que busca enquadrar o rural, definindolhe um lugar na sociedade. A valorização atual do rural apontaria para uma nova representação da relação campo/cidade apoiada na inversão da hierarquia de valores e não em contradições sociais e econômicas.

A mesma autora (idem), também destaca as contradições e particularidades presentes dentro do próprio temário rural, por vezes tratado como universo 
homogêneo, e faz críticas:

(...) Graziano da Silva parece apontar para uma interpenetração do rural e do urbano, na qual a atividade antes definidora do rural, a agricultura no sentido amplo, com suas múltiplas faces, perde substância. Por outras palavras, o rural "antigo", baseado na agricultura, cede lugar ao "novo rural", baseado na pluriatividade, também em seus múltiplos desdobramentos. (...)

Tendo por orientação o paradigma pós-industrial, por preocupação o empírico e o político e, por fonte, uma vasta bibliografia estrangeira, o "novo rural" em Graziano da Silva é paulista.

Ainda que feitas essas observações, a autora (idem, idem, p. 58) não deixará de reconhecer a nova dinâmica que atualmente emerge em muitos desses lugares, onde as "atividades rurais não-agrícolas, condicionadas pelo processo de urbanização do meio rural", determinam que sua análise "não pode restringir-se às atividades agropecuárias e agroindustriais." Complexifica-se assim a visão sobre o meio rural, envolvido com a cidade em relação de mútua dependência, onde por certos ângulos suas diferenças são nítidas e, por outros, parecem configurar um espaço indistinto. 



\section{CAPÍTULO}

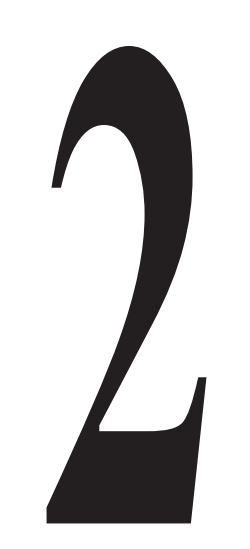




\section{2 - O espaço de Sarandira: historiografia}

No distrito de Sarandira a interação do homem com o ambiente natural foi drasticamente marcada pelo avanço da lavoura cafeeira, nos séculos XIX e $\mathrm{XX}$. Esta atividade, ligada à elite urbana da época, se desenvolveu sobre terras onde primitivamente havia uma espessa cobertura florestada, representativa da pujante mata atlântica brasileira. Se as antigas roças de subsistência que surgiram ao longo do primeiro vetor de ocupação do município - o Caminho Novo da Estrada Real - abriram frente à instalação de fazendas esparsas, dedicadas ao cultivo de uns poucos gêneros alimentícios e à criação de animais, foi apenas com a monocultura do café que enormes áreas foram efetivamente transformadas, incluídas as terras hoje pertencetes ao distrito de Sarandira.

Neste capítulo pretende-se retomar essa história, das pretéritas conjunturas espaciais aos dias de hoje. 


\subsection{Formação e evolução do distrito de Sarandira}

Para traçar o histórico das transformações da região de Juiz de Fora, que compreende o distrito de Sarandira, remetemos ao início do século XVIII, período no qual sua floresta começava a ser suprimida, instalando-se a partir de então um novo cenário com novos atores. Quanto a seus habitantes originais, não se sabe muito, exceto que à época da chegada do homem branco, pertenciam a duas etnias, a dos carijós e a dos puris. Sabe-se que era prática comum entre os indígenas a agricultura itinerante, e que para tal atividade se utilizavam de queimadas. Assim, ao longo dos milhares de anos de ocupação humana na Mata Atlântica, estima-se que toda a floresta foi em algum momento impactada. Mas sabe-se também, por meio de relatos históricos que, até o início do século XVIII, a paisagem local aparentava ser pouco ou nada antropizada, talvez apenas marcada pelas picadas indígenas - traços muito sutis e efêmeros - que, quando em desuso, acabavam engolidas pela vegetação que crescia vigorosamente em seu interior.

Concluindo, embora a rigor seja considerada uma floresta secundária, por ter certamente sofrido perturbação pela atividade humana em eras passadas, a vegetação que imediatamente precedeu a instalação dos primeiros núcleos de ocupação do atual município de Juiz de Fora era exuberante ${ }^{15}$.

Com a colonização branca deflagrou-se uma veloz predação dos recursos naturais, assim como a expulsão e o extermínio dos indígenas que ainda restavam. O ano era 1702, data de início da abertura do Caminho Novo das Minas Gerais, por onde a produção aurífera escoava de Vila Rica, atual Ouro
15 “O declínio catastrófico da população nativa que se seguiu à invasão européia do século XVI e a insignificância demográfica da imigração portuguesa concederam à Mata Atlântica um alívio, apos 10 mil anos de caça e coleta e mil anos de agricultura itinerante. A floresta que estava afastada de portos adequados ou carente de pau-brasil foi deixada em paz. Teve início um período de recomposição da vegetação e da fauna”. DEAN (1996, p. 82) 


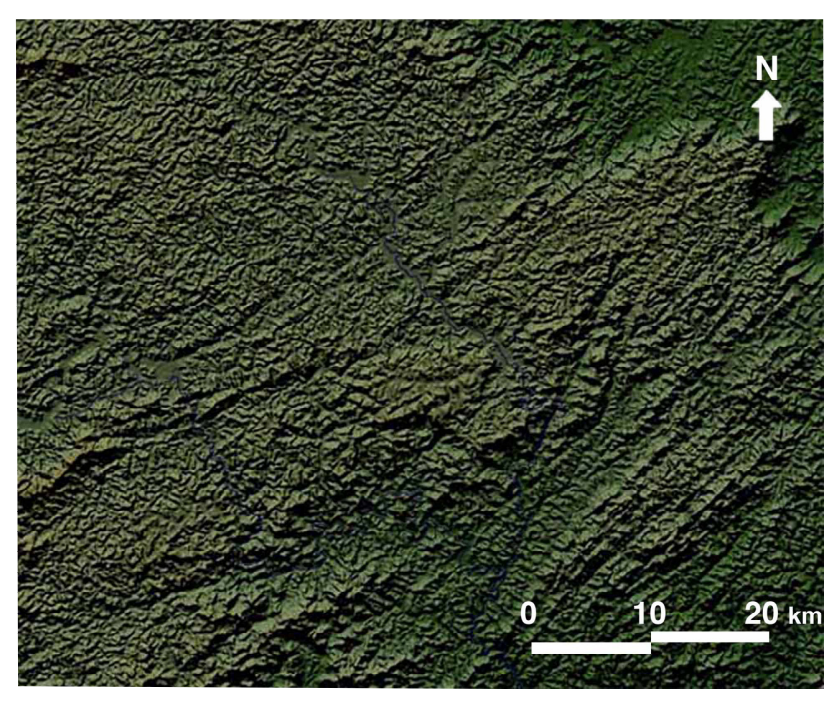

Vista simulada da região onde atualmente situase Juiz de Fora, há mais de três séculos atrás. Encobertas pelo espesso dossel das árvores estão a grande maioria dos cursos d'água e as picadas utilizadas pelos povos indígenas. Ao centro da figura destaca-se parte do vale do Rio Paraibuna, com orientação noroeste-sudeste, que no futuro abrigaria grande parte da mancha urbana do município.

Crédito: Autor. Fonte: Embrapa - Brasil em Relevo.
Preto, até São Sebastião, hoje Rio de Janeiro. Atendendo à solicitação da coroa portuguesa, Garcia Paes Leme, filho do bandeirante Fernão Dias, empreendeu a abertura do caminho, rumando para o norte, a partir da Baía de Guanabara. E por volta de 1709 , a duras penas, estava concluída a empreitada.

A exemplo de muitas cidades mineiras e fluminenses, a origem de Juiz de Fora encontra-se no desenvolvimento das roças e pousos dispostos ao longo dessa rota. O município surgiu entre dois registros da coroa situados em Barbacena, ao norte, e Matias Barbosa, ao sul. Aquele foi o primeiro a ser instalado nas Minas, e era à época conhecida por Borda do Campo, já que rumando-se em direção a Matias Barbosa, então o maior núcleo populacional da Zona da Mata, a estrada começava a adentrar uma grande extensão de florestas virgens, onde hoje situase Juiz de Fora (VALVERDE,1958). A permanência dessa cobertura vegetal entre os dois postos de fiscalização teve por muito tempo uma importância estratégica, dificultando os descaminhos do ouro para fora da rota oficial. O motivo é que a floresta era detentora de toda sorte de perigos, justificados ou não, que povoavam a imaginação dos tropeiros: feras, índios e salteadores.

A coroa passaria a incentivar o povoamento dessa região, concedendo terras a quem se comprometesse a cultivá-las, produzindo alimento para os mais diversos transeuntes, como soldados, comerciantes e viajantes, que por ali passassem. Em 1710, o secretário do governador da capitania é contemplado com uma sesmaria que abarcava parte das terras em questão. Decorridos três anos, ele as venderia a um certo juiz nascido no Rio de Janeiro, Dr. Luiz Fortes Bustamante e Sá. Logo o local passaria a ser conhecido como "Sesmaria do Juiz de Fora", possuindo como núcleo referencial sua casa-grande, então situada junto à atual zona central da cidade. Hoje, tomada por casas, prédios e ruas, não 
resta qualquer sinal daquela antiga sede de fazenda.

PROCÓPIO FILHO (1973) conta que a concessão das sesmarias teria ocorrido em 1703 ao Alcáide-Mór Tomé Correa Vasques que, já em 1708, teria fundado a Fazenda da Tapera, também na zona central da futura cidade. A segunda fazenda seria a de São Mateus, iniciada em 1709. Segundo OLIVEIRA (2005), a menção mais antiga da ocupação da região é feita por ANTONIL (1982), que descreve em 1711 a presença de roças às margens do Paraibuna.

Não se pode precisar em que época exata começaram a surgir essas primeiras roças ao longo do vale do Paraibuna, tampouco suas dimensões. Presume-se que algumas apareceram antes mesmo de terminada a rota aberta por Garcia Rodrigues. Mas haveria algum fluxo importante de viajantes por aquelas bandas antes mesmo do início da abertura do Caminho Novo, por meio das picadas indígenas? Ou seriam essas roças destinadas apenas à subsistência de seus posseiros, uns poucos desbravadores que se arriscavam naquelas áreas inóspitas? Não se sabe ao certo. Mas a despeito da inexatidão da maioria dos relatos e datas, ainda segundo OLIVEIRA (2005), seria consenso entre cronistas, geógrafos e viajantes que o efetivo povoamento do local se deu após o Caminho Novo, com a instalação de estruturas que atendiam aos tropeiros e seus animais.

A ocupação do vale do Paraibuna se dava de forma lenta, se comparada às populosas regiões auríferas. Mas no início do século XIX, com a decadência daquele ciclo, deflagrada a partir de 1760, muitos mineradores voltaram-se à ocupação da Mata. A criação de gado se intensificou, bem como o cultivo do café, que se tornaria, por volta de 1830 , o principal produto de exportação da Capitania, tendo na região da Mata seu maior centro produtor. Datam deste

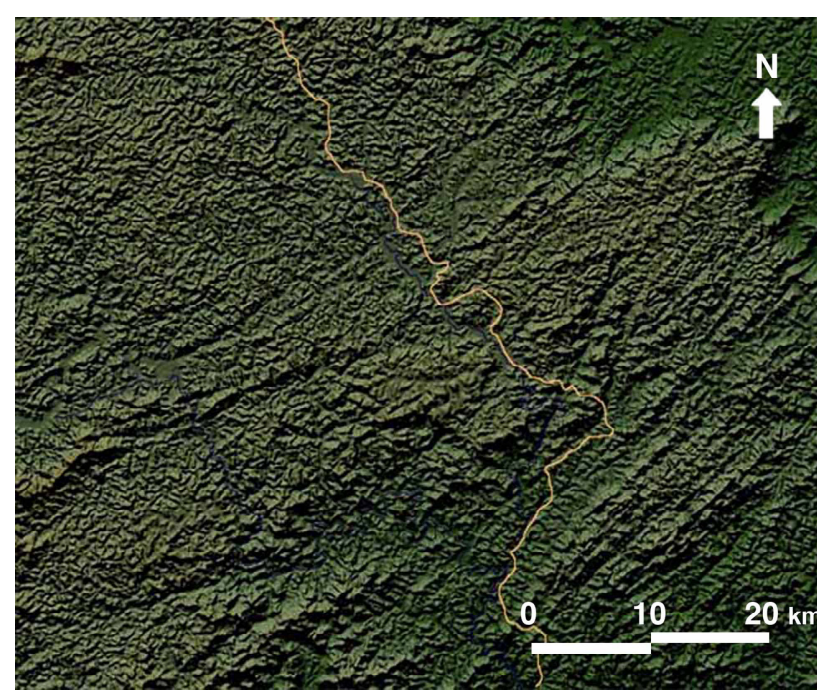

Em laranja o traçado do Caminho Novo da Estrada Real, que foi aberto a partir da Baía de Guanabara, a sudeste, rumando para o norte em direção à Vila Rica, atual Ouro Preto. Neste trecho o traçado tem como referência o vale do rio Paraibuna. (ca. 1703).

Crédito: Autor. Fontes: Embrapa - Brasil em Relevo e Guia Estrada Real para Caminhantes. 


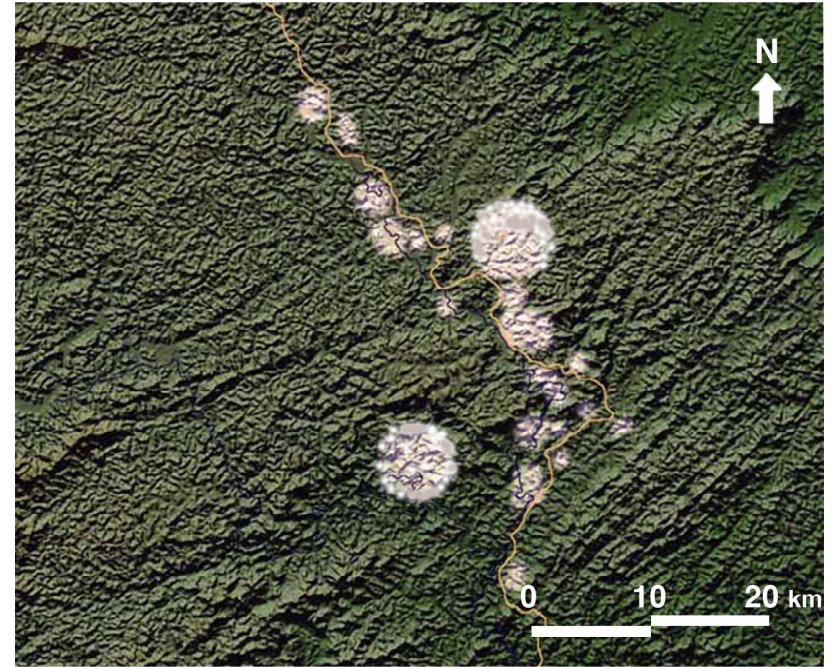

Em destaque a localização de duas fazendas de importância histórica, a de São Mateus, descolada do Caminho, a sudoeste, e a nordeste dela a Tapera, junto ao Caminho Novo. Também estão representadas propriedades menores que foram descritas ao longo do Paraibuna. (ca. 1711).

Crédito: Autor. Fontes: Embrapa - Brasil em Relevo; Guia Estrada Real para Caminhantes e Aspectos da Vida Rural de Juiz de Fora.

16 Cada ciclo econômico que marca a história do país, segundo PRADO Jr (1990), teve caráter predador. $\mathrm{O}$ autor refere-se à grande energia empregada em cada ciclo, e seu posterior abandono quando o produto não é mais demandado, resultando um território arrasado, a exemplo da cafeicultura naquela região. período as observações de WALSH (1985), que após sua passagem pela região entre 1828 e 1829 relataria a existência de dinâmicas propriedades, cujas colinas, às margens do Paraibuna, estariam cobertas até o topo por extensos cafezais. E de acordo com GUIMARÃES (2006, p. 44), entre 1855 e 1856, o município já se tornava o maior produtor da rubiácea em terras mineiras. As transformações espaciais decorrentes desta economia foram drásticas, gerando fortunas que tocavam a moderna industrialização local, às custas da dilapidação de seu meio natural ${ }^{16}$.

Mas o auge daquele ciclo econômico ainda estava por vir. Embora já no início do século XIX o Vale do Paraíba Fluminense experimentasse o rápido avanço da lavoura cafeeira, em toda a Mata a efetiva disseminação só ocorreria em meados do século, consolidando-se de vez a partir de 1870. Por aqui essa iniciativa foi tomada pelas parcelas mais ricas da sociedade, com facilidade de acesso a grandes extensões de terra e já aproveitando o conhecimento obtido com as experiências das fazendas fluminenses. Munida dessas vantagens, tornava-se ainda mais poderosa a elite local, fator que dificultava tanto a entrada de forasteiros na província quanto a multiplicação de pequenas propriedades (OLIVEIRA, 2005, p. 82). Esse enriquecimento baseado no campo era rebatido na cidade de Juiz de Fora que, de meados do século XIX ao início do século $\mathrm{XX}$, vivia um crescimento notável, revelando como uma das características específicas daquele ciclo na região o empreendedorismo de seus cafeicultores. Nesse ponto o município ganhara a alcunha de Manchester Mineira, em referência à cidade inglesa berço da Revolução Industrial, vindo a abrigar em 1861 a primeira rodovia pavimentada do país, a Estrada União e Indústria, que a conectava a Petrópolis, facilitando tanto o escoamento da produção de café quanto o acesso da capital do país a Minas, e também a primeira usina 
hidrelétrica de grande porte da América do Sul, inaugurada em 1889.

As terras situadas na extremidade leste do município, compreendidas pelo atual distrito de Sarandira, vieram a ser quase integralmente recobertas pela cultura do café, apresentando à época inúmeras fazendas com alta produtividade. Com relação ao seu desbravamento, conta-nos ESTEVES (1915) que, por volta de 1830 , portanto após a instalação das florescentes propriedades às margens do Paraibuna conforme relatos do reverendo Walsh, José Alves Pereira adquiriu terras onde hoje se localiza o núcleo urbano de Caeté. Ali encontrou grande mata virgem além de um rancho coberto com capim, possivelmente de escravos fugitivos. Procedeu-se então à derrubada das árvores e à construção da sede da fazenda, chamada Córrego da Laje. Ao que tudo indica, a partir desta incursão começou seu povoamento, inicialmente ligado a essa fazenda mas, logo em seguida, também por conta de outras grandes propriedades rurais que se instalavam.

Ainda segundo aquele autor, durante a Revolução Liberal de 1842, diversos jovens da região se juntaram aos rebeldes para combater as forças legais em Barbacena ${ }^{17}$. José Alves Pereira teria prometido doar terrenos para a efetiva fundação do arraial de Nossa Senhora do Livramento, antigo nome de Sarandira, caso os ditos combatentes voltassem sãos e salvos. Foi o que aconteceu. Em 1861 era criado o distrito de Sarandy, em homenagem à localidade homônima sul-riograndense onde havia sido travada uma importante batalha da Guerra do Paraguai. Em 1880 era elevado à categoria de freguesia.

Era composto por dois povoados distantes entre si cerca de $10 \mathrm{Km}$. Caeté, mais próximo a Juiz de Fora e localizado em terreno relativamente plano, a 600 metros de altitude, e Sarandy, implantado em um sítio montanhoso e cerca de
17 Percebe-se que num espaço de apenas doze anos, entre 1830 e 1842, havia um contingente de "diversos jovens" na região, em idade de se integrar às forças militares. Isso é um indicativo da presença de um número razoável de famílias que passaram a residir por ali, da mão de obra empregada nas fazendas e, consequientemente, $\mathrm{da}$ rápida conversão das florestas até recentemente bem preservadas, em áreas de produção agropecuária. 
18 Comparando com o quadro atual, é certo que havia no passado um número menor de propriedades, que foram sendo sucessivamente desmembradas.

19 Os escravos chegaram a constituir dois terços da população do município em 1865 (GUIMARAES, 2006, p. 44).
200 metros mais elevado que aquele. No entorno de ambos se espalhava um mosaico de sítios e fazendas ${ }^{18}$. Da riqueza gerada naquelas fazendas dependiam os dois povoados que, além de constituírem importantes núcleos religiosos, também abrigavam escola, farmácia, armazém, açougue, padaria, barbearia, alfaiataria, ferraria, funilaria, correios, etc (ESTEVES, 1915).

Em 1915, Caeté contava com 400 habitantes, e Sarandy 200. Mas a soma destes e dos demais, que residiam fora dos arraiais, era de 6.500 habitantes, o que dá a dimensão da força de trabalho outrora empregada nas lavouras ${ }^{19}$. E foi apenas às custas da mão-de-obra escrava que se viabilizou a fantástica transformação daquele espaço, posteriormente com a adição de trabalhadores livres e imigrantes europeus, conforme GUIMARÃES (2006, P. 46):

\begin{abstract}
Como em outras regiões cafeeiras do país, a segunda metade do oitocentos foi marcada, em Juiz de Fora, pela discussão em torno da substituição do braço escravo e do futuro das lavouras. Foi um período de lutas, conflitos e incertezas. Aos escravos, somaram-se, aos poucos, o trabalhador livre local (libertos e despossuídos) e os imigrantes, principalmente os alemães e os italianos.
\end{abstract}

Ali não se verificava a existência de uma cultura genuinamente caipira. Como dominava na região a grande propriedade, não há indícios de uma sociabilidade coesa fora dos dois povoados e das fazendas, que poderia congregar pequenos produtores donos da própria iniciativa de trabalho e que realizassem um mínimo ajuste ecológico, a exemplo daqueles que caracterizavam os bairros 
rurais comuns a outras regiões dos estados mineiro e paulista ${ }^{20}$. Corrobora para isso a observação de CANDIDO (1964, p. 117): “Onde o latifúndio ocorre, os parceiros, colonos ou salariados se concentram em agrupamentos liderados pela fazenda, que interfere na estrutura do bairro, abala os padrões tradicionais e promove a reorganização das relações." Pasquale Petrone (apud PEREIRA DE QUEIROZ, 1973, p. 30) também formulou a hipótese de que a "civilização do café" transforma e arruína a "cultura caipira". PEREIRA DE QUEIROZ (1973, p. 30) concorda com esta afirmação, destacando que a cultura ligada à rubiácea irá, ao menos enquanto durar, abafar as manifestações caipiras "obscurecidas pelo esplendor" do modo de vida dos fazendeiros. E naquelas referidas terras, desde o início de sua apropriação, todas atividades giravam em torno da monocultura de exportação, seja diretamente em sua produção ou ainda em seu suporte, ocupando extensões menores do terreno com o plantio de milho, feijão, arroz e mandioca, ou com a reserva de pastagem para os animais, que também forneciam alimento, além de tração e montaria.

Por volta de 1930, o café começava a perder força na região. O ciclo econômico entrava em colapso e, com ele, o distrito. Os fatores que levaram a tal situação foram muitos: a quebra da Bolsa de Nova York em 1929, a pouca assistência do governo estadual, a distância aos portos de exportação, a diminuição da mão-de-obra, o progressivo esgotamento dos solos e o emprego de técnicas de cultivo inadequadas. Muitos dos grandes cafeicultores, por terem investido boa parte de seus lucros no desenvolvimento urbano e industrial da cidade, portanto diversificando suas atividades, não sofreram tanto os impactos da crise. Já entre os trabalhadores rurais as conseqüências foram severas, e determinaram o êxodo em massa que se viu na região.
20 Algumas dessas unidades de povoamento foram objeto de investigação para Antonio Candido em Parceiros do Rio Bonito (entre 1947 e 1954), e também para Maria Isaura Pereira de Queiroz em Bairros Rurais Paulistas (1962), obras clássicas entre os tratados sociológicos do mundo rural brasileiro. Mais recentes, os estudos realizados por José Pedro de Oliveira Costa e Maria de Lourdes Zuquim, respectivamente sobre Aiuruoca e o Vale do Paraíba, ajudaram a reescrever a abrangência dos estudos do meio rural pela óptica da paisagem e do ambiente, constituindo duas importantes contribuições para esta dissertação.

Sobre a região aqui estudada, no passado, assim como hoje, os mais humildes habitantes locais donos da própria iniciativa de trabalho eram pequenos sitiantes que viviam em situação muito privilegiada se comparados àqueles pobres parceiros paulistas descritos por Antonio Candido. Ainda que se tenha conhecimento da existência, até poucas décadas atrás, de uma ou outra família que vivia em estado de penúria, estas não configuravam unidades coesas e homogêneas como as retratadas nas investigações dos bairros rurais de São Paulo. Eram em geral uns poucos colonos que conseguiam autonomia para viver de um pequeno pedaço de chão com o consentimento do patrão, ou ainda escravos libertos e seus descendentes que por ali permaneceram. 
21 Crédito: Autor. Fontes: Álbum do Município de Juiz de Fora 1915. Plano Diretor Municipal 2004. Enciclopédia dos municípios brasileiros - IBGE, 1958.

*Número estimado.

22 Citando SOTO (2002, p. 48): “Diferentes autores também discordam sobre as principais causas das migrações rurais-urbanas: uns colocam ênfase nos fatores de expulsão, principalmente devido à concentração da terra e às dificuldades de fixação do homem no campo, enquanto que outros destacam os fatores de atração. O certo é que as migrações brasileiras têm sido provocadas por ambos fatores."
ASPECTOS DEMOGRÁFICOS DO DISTRITO DE SARANDIRA ${ }^{21}$

\begin{tabular}{|c|c|c|c|c|c|c|c|}
\hline Ano & 1915 & 1958 & 1970 & 1980 & 1991 & 1996 & 2007 \\
\hline Moradores & 6500 & 2025 & 1584 & 1261 & 1025 & 998 & $1400 *$ \\
\hline
\end{tabular}

A tabela acima ilustra como este fenômeno pode ser percebido em meados do século XX, deflagrado pela crise do setor cafeeiro que atingiu a região a partir dos anos 30. Essa migração para as cidades ocorreu após quase cem anos de intenso povoamento. Portanto, essa redução abrupta verificada entre os anos de 1915 e 1958, foi em grande parte decorrente da liberação da mão-de-obra negra empregada na lavoura cafeeira. Certamente é necessário considerar também a atração exercida por Juiz de Fora e, de forma geral, pela maioria das cidades nos anos que se seguiram às décadas de 30 e 40 do século passado ${ }^{22}$. O que se verificou posteriormente, até meados dos anos 90 , foi a contínua redução de sua população.

Esta saída em massa para a cidade foi, sem dúvida, menos sentida no povoado de Caeté do que na vila de Sarandira. Esta era o coração daquela zona rural, e vivia em total dependência das propriedades que a circundavam, acabando por ficar completamente ilhada em meio a propriedades decadentes. Caeté, por sua maior proximidade com a cidade, teve garantida a sua sobrevida.

Quantoa suas fazendas, mais notadamente suas casas-grandesque, comparadas às demais edificações das propriedades permaneceram bem preservadas, tornaramse apenas marcos na paisagem de um passado de grande dinamismo e opulência, 
um forte contraste com os dias de hoje. Mas essa foi uma transição gradual. A cafeicultura foi sendo paulatinamente substituída pela pecuária leiteira. O que restou dos últimos pés de café foi queimado por volta dos anos 60 e 70, dando lugar a pastagens. Ocorreu que o leite não conseguiu impulsionar a retomada do desenvolvimento local. Firmando-se simultaneamente como produto e agente do empobrecimento da região, ele garantia apenas subsistência ou parcos lucros aos sitiantes que não conheciam outra fonte de renda, ou instalava a apatia entre os proprietários mais abastados que, por não vislumbrarem qualquer possibilidade de reviver os tempos áureos do ciclo econômico anterior, dedicaram-se mais a suas outras atividades, urbanas, vendendo ou arrendando suas terras, ou ainda as conservando de forma precária, com número reduzido de empregados.

A decadência do trabalho ligado à terra se arrastaria ao longo dos anos. No entanto, o quadro relativo à demografia do distrito a partir da primeira década do século XXI passou a revelar um curioso crescimento populacional, indício de um espaço novamente em franca mutação. 


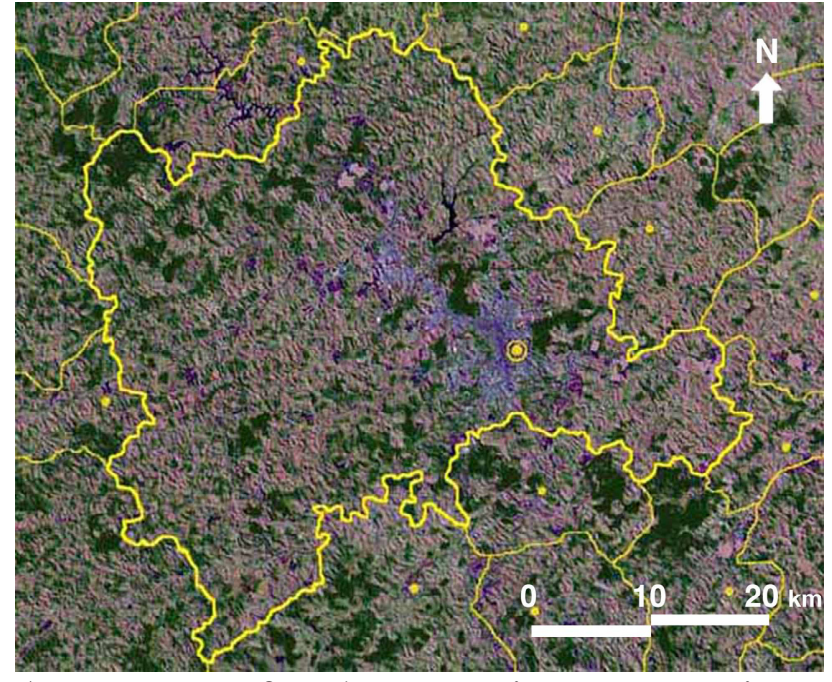

A mesma área focada nas três imagens anteriores é aqui retratada como se encontra na atualidade, evidenciando a fragmentação de sua divisão política, e tendo em destaque o município de Juiz de Fora. Também notável foi o desenvolvimento de sua área urbanizada, ao centro, e a forte redução das áreas florestadas em toda a região

Crédito: Autor. Fonte: Embrapa - Brasil Visto do Espaço.

23 Números colhidos em investigações de campo, em meados de 2007, que complementam os últimos dados oficiais provenientes do censo rural realizado pelo IBGE em 2000.

24 As informações relativas ao Distrito de Sarandira listadas ao lado (Crédito: Autor.), foram adaptadas ao quadro referente às formas de povoamento disperso que se observava na área

\subsection{As atuais dinâmicas da produção espacial}

$\mathrm{Na}$ atual divisão administrativa do município de Juiz de Fora, o distrito de Sarandira situa-se em sua extremidade leste, ocupando uma área de 103 km², fazendo fronteira com os municípios de Santana do Deserto e Matias Barbosa ao sul, Bicas e Chácara ao norte, e Pequeri ao leste. Ainda de acordo com a corrente visão oficial, a qual será apresentada com maior profundidade ao final deste capítulo, seus dois povoados, Caeté e a vila de Sarandira (esta última considerada "Sede" do distrito) receberam a nomenclatura de "Núcleos Urbanos", envoltos pela "Zona Rural" do distrito, composta por propriedades de tamanhos variados. Sobre essa matriz heterogênea de terrenos que vão desde os reduzidos lotes urbanos dos dois núcleos até alguns extensos latifúndios que os circundam, distribui-se sua população. Estima-se que hoje existam 800 moradores no povoado de Caeté, habitando 300 casas. Na vila de Sarandira, algo próximo de 200 pessoas, ocupando menos de 100 casas. Nas propriedades do entorno cerca de 400 pessoas distribuem-se por um numero estimado em 20 fazendas, 25 sítios e igual número de pequenas chácaras ${ }^{23}$.

CARACTERIZAÇÃO E DISTRIBUIÇÃO DOS MORADORES NO DISTRITO ${ }^{24}$

\begin{tabular}{|l|c|l|c|}
\hline Tipos de morador & Natureza da ocupação & Tipo de moradia & Unidade de agrupamento \\
\hline Transitório (colono) & Consentida ou de fato & Casa & Terras da fazenda \\
\hline Permanente & $\begin{array}{r}\text { a/b- Propriedade ou } \\
\text { arrendamento }\end{array}$ & $\begin{array}{l}\text { a- Sítio } \\
\text { b- Fazenda } \\
\text { a- Sitiante } \\
\begin{array}{l}\text { b- Fazendeiro } \\
\text { c- Morador de povoado }\end{array}\end{array}$ & $\begin{array}{l}\text { a- Localidades, ou esparsa } \\
\text { b- Não há (esparsa) } \\
\text { c- Povoados }\end{array}$ \\
\hline
\end{tabular}




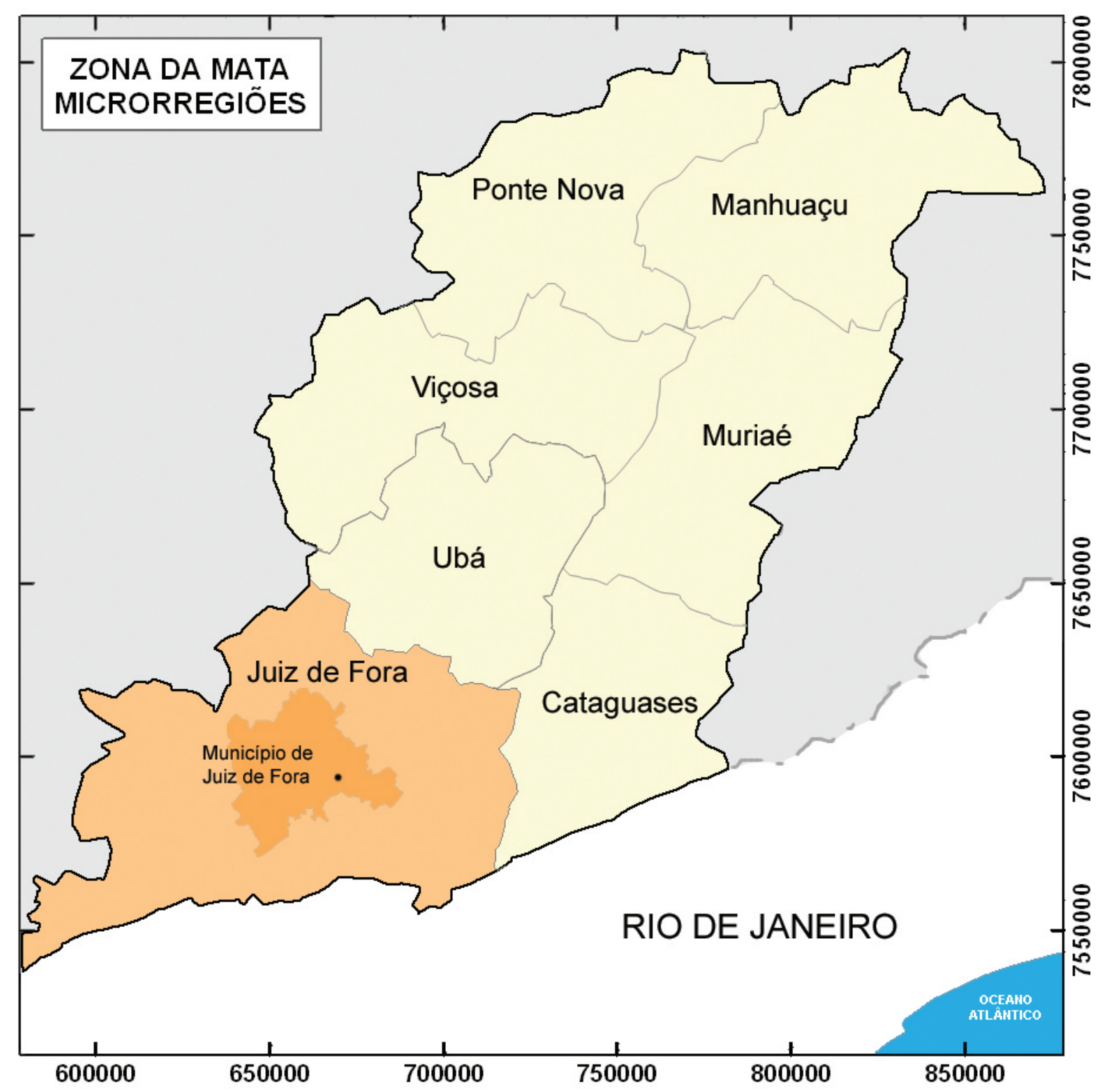

\section{LEGENDA}

- Cidade de Juiz de Fora

- Limite de Estados

L Limite das Microrregiões

- Limite da Zona da Mata

Datum WGS - 1984 Zona 23 Sul.

DEMERCATOR $1: 2.000 .000$
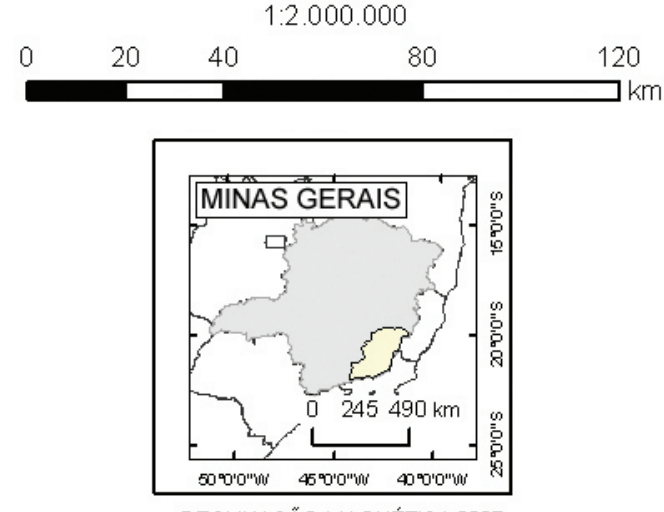

DECLINAÇÃO MAGNÉTICA 2007

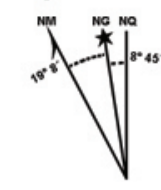

ADECLNACXOMAGNEICA
CRESCET ANUALMENTE

JUIZ DE FORAMG) 


\section{LEGENDA}

Zona Urbana

() Cidade (sede de Município)

○ Vila (sede de distrito)

Limite de distrito

Limite do Município de Juiz de Fora

Datum WGS - 1984 Zona 23 Sul.

PROJEÇ,AO UNIVERSAL TRANSVERSA DE MERCATOR
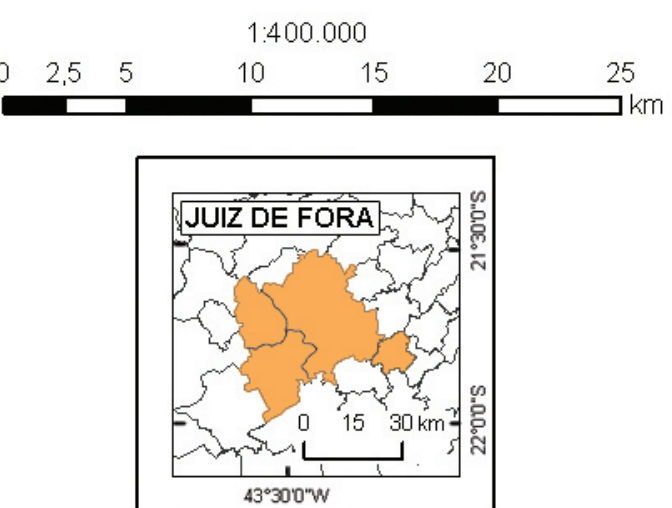

DECLINAÇÄO MAGNĖTICA 2007

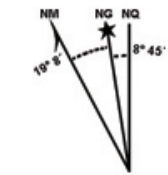

ADECLINACXO MASNEICA
CRESCE? ANUALMENTE

JUIZ DE FORAMMO

FONTE: AGUIAR, Valéria Trevizani Burla de. Atlas Geográfico Escolar de Juiz de Fora. Juiz de Fora Editora: UF.J., 2000 .

DESENHISTA: BOSCARIOL, Antonio C. (arttonioboscariol@grnail.com)

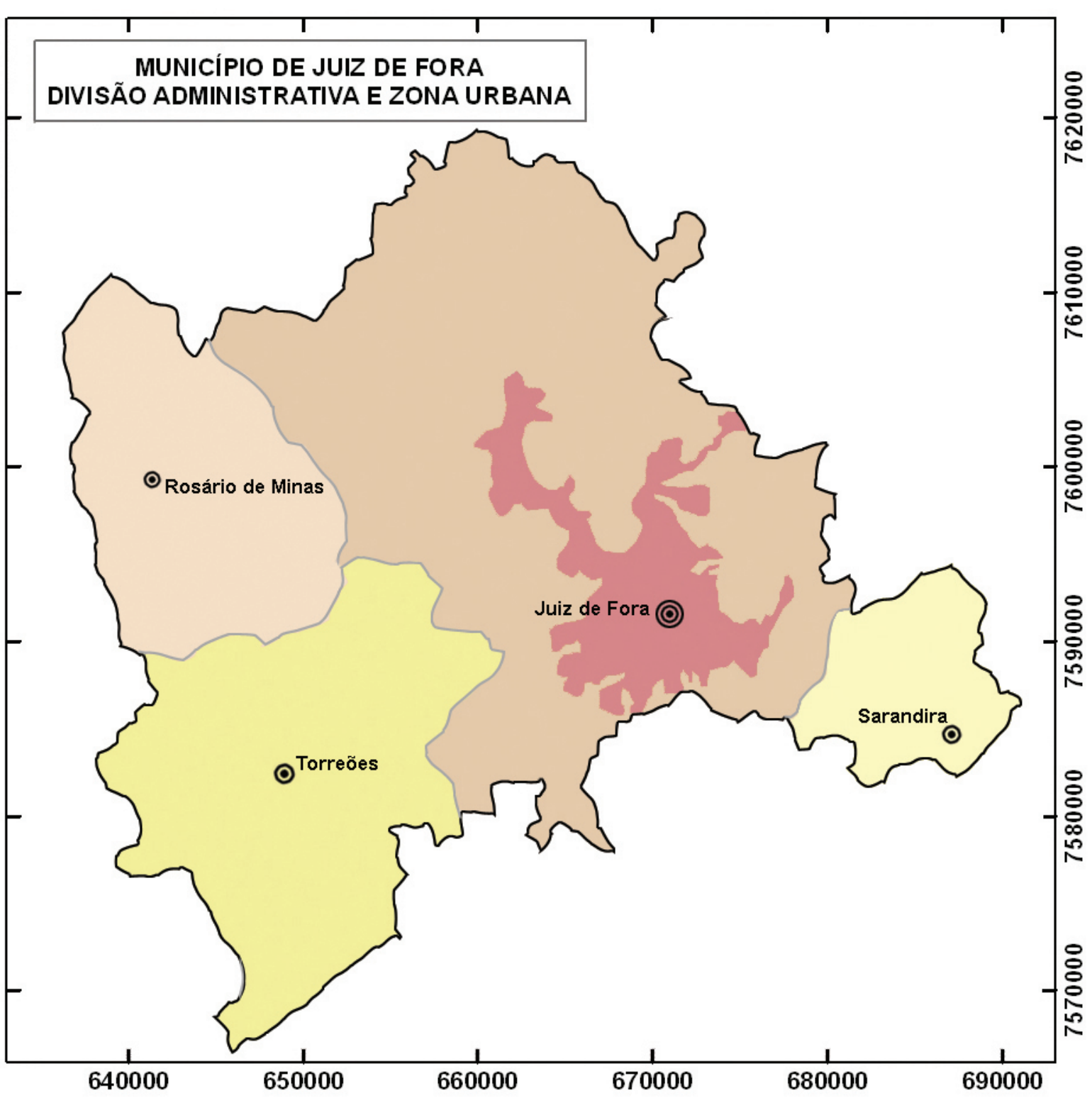




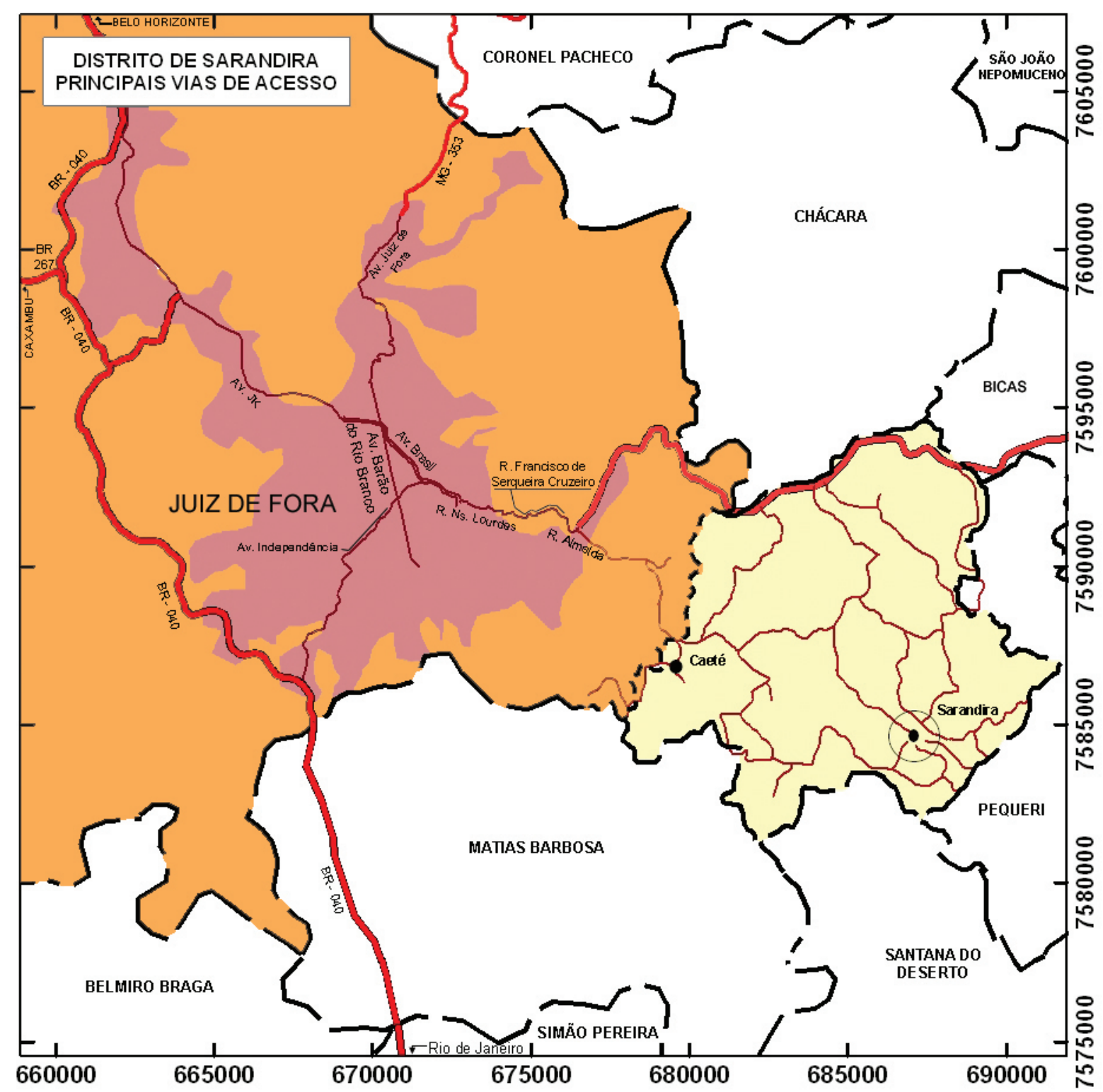

\section{LEGENDA}

Distrito de Sarandira

Vias de Circulação

Zona Urbana

- Vila (sede de distrito)

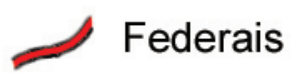

- Povoado

Limite de Município

- -. Limite de Distrito

Datum WGS - 1984 Zona 23 Sul.

AN UNIVRSAL TRANSVERSA DEMERCA

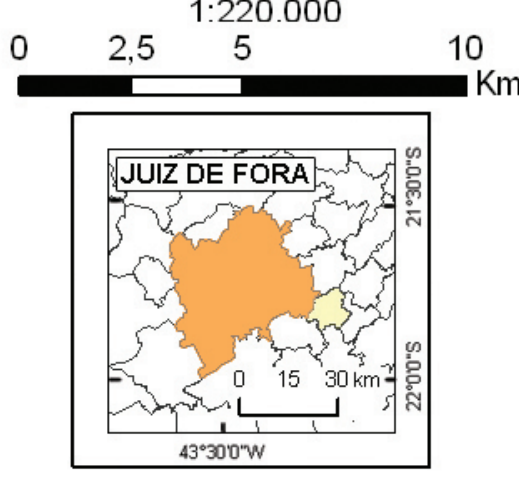

DECLINAÇÃO MAGNÉTICA 2007

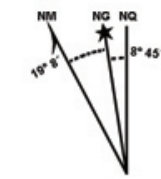

ADECLNAGAO MAGNGICA
CRESCE? ANUALMENTE

$$
\text { JUIZ DE FORAMG }
$$

FONTE:AGUIAR, Valéria Trevizani Eurla de. Atlas Geográfico Escolar de Juiz de Fora. Juiz de Fora Editora. UF , 2000. ORGAOO UNIVERSIDADE FEDERAL DE JUIZ DE FORA. 
de estudo contemplada por Antonio Candido em Parceiros do Rio Bonito (1964, p. 78). Como naquele estudo, há que se chamar atenção quanto a dois termos freqüientemente utilizados: sítios e fazendas. A distinção genérica que se faz entre ambos é com relação a seu tamanho, embora este seja um critério vago e relativizado. Podese considerar que fazendas de maior importância possuem entre 200 e 500 hectares em média, enquanto os sítios têm entre 30 e 100 hectares. Mas uma propriedade de grandes dimensões desprovida de benfeitorias ou que não possui uma produção significativa, não costuma ser chamada de fazenda, apenas de "terra". Da mesma forma, uma propriedade menor com grande produção e emprego de mão de obra pode ser considerada uma "fazendinha".

25 Durante o ano de 2006, o valor mínimo pago no litro do leite foi de $\mathrm{R} \$ 0,40$ nos meses de janeiro, fevereiro e março. Esse período do ano corresponde à época chuvosa, em que a produção aumenta por conta da maior disponibilidade de alimento para o gado. Os capins estarão tão saturados de água que o leite produzido terá menores taxas de gordura, sendo portanto menos valorizado. Situação diametralmente oposta ao período mais seco, de inverno, em que paga-se mais por cada litro, mas o volume produzido cai significativamente. $\mathrm{O}$ valor máximo pago pelo litro naquele ano foi referente ao mês de agosto, $\mathrm{R} \$ 0,65$. Média anual em torno de $\mathrm{R} \$ 0,50$. Em 2007 os valores respectivos foram $\mathrm{R} \$ 40,00$, $\mathrm{R} \$ 45,00$ e $\mathrm{R} \$ 50,00$ sobre janeiro, fevereiro e março, e R\$ 0,90 em julho e agosto, com média de R $\$ 0,65$. Ainda: todos os valores descritos
Com relação às atividades econômicas ali desenvolvidas, a pecuária leiteira é a de maior importância. Sua baixa rentabilidade é a principal responsável pelo raquitismo da economia local. Assim, mal remunerados, os proprietários de terras não conseguem investir em melhorias na produção, estabelecendo um círculo vicioso que os condena permanentemente à estagnação. Após o trabalho de separar as vacas em lactação, ordenhá-las manualmente, muitas vezes tendo que complementar sua alimentação com ração industrializada, comprando também produtos veterinários e, para os que dispõem de mão-deobra, remunerar seus funcionários, recebe-se em média $\mathrm{R} \$ 0,65$ por litro ${ }^{25}$. Trabalho árduo realizado todos os dias do ano, sem exceção.

É necessário destacar que apenas os grandes produtores conseguem obter um lucro significativo, já que este está diretamente ligado à escala da produção. $\mathrm{O}$ magro capital excedente costuma não ser reincorporado nessas fazendas, na dinamização do processo, isso porque a maior parte dos grandes proprietários tem a agropecuária apenas como atividade complementar de suas rendas, ou hobby, não havendo uma dedicação às suas terras comparável à dos antigos barões do café, que costumavam residir no campo e passar apenas os finais de semana na cidade. Os atuais fazem o inverso, e muitos até residem em outros municípios e estados.

Mas a manutenção de terras no distrito, especialmente as grandes fazendas, também é motivada como oportunidade de negócio, com fins especulativos. Essas propriedades rurais, se comparadas aos imóveis urbanos, mudam muito rapidamente de mãos, tanto que nos últimos quatro anos, no período de 2003 a 2007, mais da metade de todas elas já havia sido vendida .

Como resíduos deste processo, sofrendo as conseqüências da baixa lucratividade 
da pecuária leiteira e da veloz comercialização das propriedades, estão os mal remunerados trabalhadores rurais assalariados que não dispõem de terras para seu próprio sustento. A despeito do desejo de se tornarem patrões, dificilmente conseguirão superar sua condição de empregados, como concluem alguns estudiosos do mundo rural (SOTO , 2002, p. 35):

Martins considera que o camponês incorpora a ideologia burguesa, adquirindo a idéia de se tornar proprietário, mas a realização desse objetivoé obstaculizada pela sua condição de exploradoe expropriado. Então, para Martins, o camponês é portador da ideologia burguesa, mas ele é objetivamente incapaz de realizá-la, devido aos obstáculos estruturais que impossibilitam que se torne proprietário da terra, o que significaria ser proprietário de capital.

RENDIMENTO MENSAL DOS RESPONSÁVEIS POR SEU DOMICÍLIO ${ }^{26}$

\begin{tabular}{|l|l|c|c|c|c|c|}
\hline Local & total & Até 1 salário & $\begin{array}{l}\text { De 1 a 2 } \\
\text { salários }\end{array}$ & $\begin{array}{l}\text { De 2 a 5 } \\
\text { salários }\end{array}$ & $\begin{array}{l}\text { Mais de 5 } \\
\text { salários }\end{array}$ & Sem rendimento \\
\hline $\begin{array}{l}\text { Distrito Sede de } \\
\text { Juiz de Fora }\end{array}$ & 453.698 & 66.579 & 90.966 & 129.473 & 143.325 & 23.355 \\
\hline Rosário de Minas & 1.726 & 534 & 682 & 344 & 100 & 66 \\
\hline Sarandira & 1.161 & 506 & 344 & 173 & 66 & 72 \\
\hline Torreões & 2.177 & 837 & 634 & 441 & 94 & 171 \\
\hline
\end{tabular}

são relativos ao total bruto, não descontados os quase $10 \%$ de taxa de manutenção cobrada pela cooperativa, que tem custos com o transporte e armazenamento da produção, e pagamento de funcionários.

Há duas cooperativas de leite no distrito. A de Caeté recolhe a produção das imediações daquele povoado. Ao tanque da cooperativa de leite situada na vila de Sarandira, para onde vai grande parte da produção local, são enviados em média 85 litros de cada uma das cerca de 35 propriedades, totalizando 3 mil litros a cada dia. A maior produtora, com alguns empregados e ordenhadeiras mecânicas, para lá envia 480 litros em média. $\mathrm{O}$ menor produtor contribui com apenas 5 litros de leite diários.

26 Crédito: Autor. Fonte: IBGE, Censo Demográfico 2000. 
27 Crédito: Autor. Fonte: IBGE, Censo Demográfico 2000
Analizando o rendimento mensal dos responsáveis por seu domicílio (tabela acima) verifica-se que o número de pessoas responsáveis pelo domicílio que recebem até 1 salário mínimo, muitos deles chefes de família com filhos, chega quase à metade dos moradores de Sarandira. Situação pouco pior do que aquela apresentada em Rosário de Minas, e melhor que em Torreões, que são os demais distritos rurais do município. Na cidade, essa razão já cai para uma em cada sete pessoas. No distrito de Sarandira há ainda um número expressivo dos que não possuem qualquer fonte de renda: uma em cada 17 pessoas.

A permanência da classe trabalhadora nessas condições acaba perpetuando seu atraso, alimentando estatísticas como as referentes ao analfabetismo, elevado em toda a zona rural do município.

\begin{tabular}{|l|c|c|c|c|c|c|c|c|}
\hline POPULAÇÃO RESIDENTE ALFABETIZADA 27 \\
\begin{tabular}{|l|c|c|c|c|c|c|c|}
\hline Total \\
alfabetizada
\end{tabular} & n/ alf. & $\begin{array}{l}\text { Com 5 anos } \\
\text { de idade } \\
\text { alfabetizada }\end{array}$ & $\begin{array}{l}\text { Entre 15 e 29 } \\
\text { anos de idade } \\
\text { alfabetizada }\end{array}$ & $\begin{array}{l}\text { 60 anos ou } \\
\text { mais } \\
\text { alfabetizada }\end{array}$ & n/ alf. \\
\hline $\begin{array}{l}\text { Distrito } \\
\text { Sede de } \\
\text { Juiz de } \\
\text { Fora }\end{array}$ & 391.143 & 30.626 & 807 & 6.542 & 34.590 & 592 & 41.045 & 7.229 \\
\hline $\begin{array}{l}\text { Rosário } \\
\text { de Minas }\end{array}$ & 1.284 & 277 & 1 & 44 & 157 & 4 & 71 & 77 \\
\hline Sarandira & 859 & 197 & 5 & 13 & 71 & 9 & 81 & 56 \\
\hline Torreões & 1.617 & 388 & 6 & 33 & 148 & 12 & 141 & 111 \\
\hline
\end{tabular}


Entre a população total que vive na cidade, um em cada 13 moradores não é alfabetizado; nos distritos essa razão é de um para 5. Em Sarandira, a proporção de analfabetos entre os 15 e os 29 anos de idade e também entre os que têm mais de 60 anos, comparados ao mesmo grupo etário que vive na cidade, é cinco vezes maior.

Com relação a dados ligados à saúde de seus moradores, dos 315 domicílios particulares permanentemente ocupados quatro não possuem banheiro ou mesmo qualquer tipo de sanitário. Ainda assim esse índice é melhor do que nos demais distritos rurais ${ }^{28}$. O lixo é coletado em 205 moradias, ao passo que nas demais é, na maior parte, queimado. Tais números são comparáveis aos dos demais distritos.

De acordo com a tabela seguinte, referente aos grupos de idade e sua distribuição no município de Juiz de Fora, pode-se inferir que, entre 1985 e1990, no distrito de Sarandira, mais provavelmente no povoado de Caeté $^{29}$, o número de nascimentos, ou a chegada de novas famílias com filhos recém nascidos, foi $20 \%$ maior que para os demais distritos e a cidade, o que indica um período de maior otimismo e crescimento naquela localidade. A partir de 1990 houve uma desaceleração deste processo e as taxas do município como um todo se equipararam. O grupo compreendido entre os que possuem de 16 a 54 anos de idade abarca metade da população total em todas as regiões avaliadas. No entanto, do grupo dos que possuem entre 55 e 64 anos, Sarandira apresenta a menor concentração, uma em cada 22 pessoas, contra uma em 15 na cidade. É possível que aqueles, não tendo mais a mesma capacidade de desenvolver as tarefas pesadas exigidas pela vida no campo, acabem migrando para a cidade. Ocorre o contrário na faixa que abriga os indivíduos de 65 a 74 anos de idade.
28 Fonte: Censo IBGE 2000.

29 Os dados levantados não fazem distinção entre os dois núcleos urbanos, porém é certo que este crescimento populacional esteja ligado a Caeté, já naquela época mais próspero que a decaída vila de Sarandira. 
Entre estes, o número dos que vivem na cidade cai para um a cada 22, mas em Sarandira sobe para um a cada 15 pessoas. Aqui é provável que, tendo residido um período, ou mesmo toda a vida na cidade, essas pessoas agora aposentadas tenham decidido viver no campo. O número de pessoas com mais de 75 anos é $15 \%$ superior na cidade, provavelmente pelas facilidades ali oferecidas, melhores condições de tratamento médico e proximidade de seus parentes mais jovens.

POPULAÇÃO RESIDENTE POR GRUPOS DE IDADE ${ }^{30}$

\begin{tabular}{|l|c|c|c|c|c|c|c|c|c|}
\hline Local & Total & $\begin{array}{l}\text { 0 a 9 } \\
\text { anos }\end{array}$ & $\begin{array}{l}\mathbf{1 0} \text { a 15 } \\
\text { anos }\end{array}$ & $\begin{array}{l}\mathbf{1 6} \text { a 24 } \\
\text { anos }\end{array}$ & $\begin{array}{l}\mathbf{2 5} \text { a 34 } \\
\text { anos }\end{array}$ & $\begin{array}{l}\mathbf{3 5} \text { a 54 } \\
\text { anos }\end{array}$ & $\begin{array}{l}\mathbf{5 5} \text { a } 64 \\
\text { anos }\end{array}$ & $\begin{array}{l}\mathbf{6 5} \text { a } \\
\mathbf{7 4} \\
\text { anos }\end{array}$ & $\begin{array}{l}\text { mais de } \\
\mathbf{7 5} \text { anos }\end{array}$ \\
\hline $\begin{array}{l}\text { Distrito } \\
\text { Sede de Juiz } \\
\text { de Fora }\end{array}$ & 456.796 & 72.055 & 46.971 & 76.288 & 71.353 & 124.884 & 31.347 & 21.609 & 12.289 \\
\hline $\begin{array}{l}\text { Rosário de } \\
\text { Minas }\end{array}$ & 1.732 & 342 & 185 & 295 & 318 & 390 & 95 & 70 & 37 \\
\hline Sarandira & 1.161 & 203 & 146 & 192 & 170 & 290 & 54 & 80 & 26 \\
\hline Torreões & 2.181 & 388 & 235 & 305 & 356 & 564 & 157 & 121 & 55 \\
\hline
\end{tabular}

Dada a inseparabilidade das questões sociais e econômicas, qualquer mudança em uma dessas dimensões complementares implica em profundos desdobramentos. Por lá, a cada nova perspectiva de maior oferta de empregos - raramente concretizada - renovam-se as esperanças de seus moradores por 
melhores condições de vida. É uma procura permanente, que forçou a maioria a se adaptar a todo tipo de serviço e sua instabilidade, seu caráter notadamente temporário, transitório.

Nesse aspecto, cada vez mais insatisfeitos com a baixa rentabilidade da pecuária leiteira, muitos produtores estão se voltando para a pecuária de corte, enquanto uns poucos para o plantio homogêneo de eucalipto. A mais provável consequiência desta mudança é o agravamento da liberação da mão-de-obra nas propriedades, já que ambas atividades são menos intensivas com relação a seu manejo.

Outra atividade que agora começa a ser explorada, ainda timidamente, é o turismo de natureza. Embora esteja em um estágio muito incipiente para permitir maiores considerações, é provável que dada a crescente valorização dessa categoria do turismo, ele venha adquirir cada vez maior vulto. Mas, por enquanto, um dos bens capazes de assegurar seu desenvolvimento parece estar sendo negligenciado: seu patrimônio arquitetônico e histórico-cultural, tanto nas fazendas e sítios quanto nos núcleos urbanos. Exemplo de que a pluriatividade não é uma das características da região. Poucas são as famílias de pequenos agricultores e pecuaristas que diversificam suas fontes de renda, como na manufatura de bens acabados ou na prestação de serviços, por conta basicamente da falta de tempo livre, decorrente das tecnologias ultrapassadas ainda empregadas no campo, que tornam árduos seus afazeres. Os grandes donos de terra, como já foi descrito, têm outras preocupações além da produtividade de suas fazendas. E, por fim, os moradores dos dois povoados, cada vez menos ligados às atividades agropecuárias, aceleram as transformações dessas localidades, tornando-as mais distantes do universo rural. 
${ }^{31}$ O povoado que originou Pequeri, originalmente São Pedro do Piquiri, pertenceu a Sarandira por volta de 1870, emancipando-se em 1890.

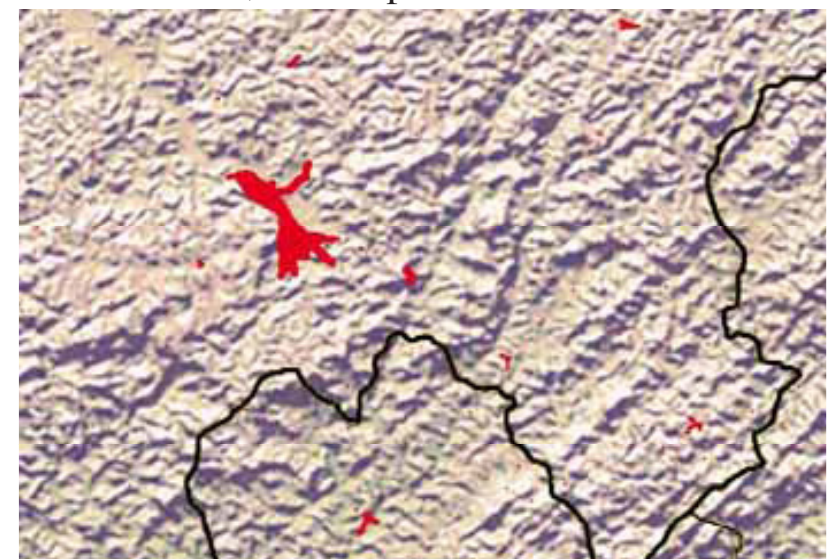

Imagens da mesma área de Juiz de Fora, acima, em 1936, e abaixo, em 2005, expressam o crescimento de sua mancha urbana, bem como as alterações de seus limites administrativos.

Crédito: Autor. Fontes: Comissão Geographica e Geologica de Minas Geraes e Embrapa - Brasil Visto do Espaco.
Este tem sido um fenômeno notável. Com a falência da vida rural inalgurada nas primeiras décadas do século XX, a vila de Sarandira começou a agonizar, e assim veio se arrastando até os dias de hoje. Caeté, que já dependia menos do campo que o circundava, hoje, com a aproximação da mancha urbana e da rede de serviços públicos depende menos ainda, e cresce à revelia do entorno rural, ou melhor, sobre ele.

$\mathrm{Na}$ vila de Sarandira surpreende o fato de haver algumas pessoas que, apesar da longa distância e das estradas mal conservadas, se deslocam todos os dias para trabalhar em Juiz de Fora. Sua proximidade com o município de Pequeri ${ }^{31}$, distante apenas $4 \mathrm{~km}$ a leste, promove a rápida ligação entre ambos. Relação que, no entanto, para o distrito, sequer se compara à sua dependência com o centro de Juiz de Fora, distante $20 \mathrm{Km}$. Mas, a despeito dessas conectividades, seu traço mais expressivo está em seu isolamento. Exceto nos dias de festa religiosa, ou com a realização anual do torneio leiteiro, toda a vila parece estar adormecida. Não há oferta significativa de empregos, ou ainda empregos estáveis. Os homens em condição de trabalhar são geralmente pagos por dia de serviço e são apenas temporariamente empregados nas propriedades do entorno. Uma parcela importante de seus moradores é formada por aposentados, muitos possuindo outra residência na cidade. Com isso vê-se poucas pessoas nas ruas, e a aglomeração mais freqüente, não mais que meia dúzia de homens, acontece em torno de uma de suas duas vendas. As poucas crianças do curso primário, por conta da rotineira falta de professores para esta localidade, estão agora tendo aulas em Caeté.

Este último povoado apresenta características bem distintas daquelas da vila de Sarandira, por conta de seu incremento populacional e econômico. Ao contrário 
de Sarandira, dele distante $15 \mathrm{Km}$, vem experimentando o aporte constante de novos moradores, facilitado pelo recente asfaltamento de sua principal estrada de acesso $^{32}$, e pela ampliação da linha Centro-Caeté que agora os conecta em menos de quarenta minutos ${ }^{33}$. Ao longo da referida via surgiram também loteamentos, que subdividiram em pequenas parcelas os antigos latifúndios, onde têm proliferado tanto residências permanentes quanto casas de campo. Neste vilarejo percebe-se que os traços de ruralidade estão se perdendo de forma acelerada, e a dependência das atividades ligadas à terra torna-se cada vez mais rara. Caeté, continuamente, vem se assemelhando a um bairro com características comuns àquelas da periferia da cidade. Fenômeno potencializado pelo considerável numero de recém chegados, ex-moradores da cidade, atraídos pelos baixos preços dos terrenos à venda e também pelas paisagens bucólicas e pelo modo de vida pacato que se espera encontrar por lá.

No povoado existem três bares, restaurante, loja de armarinhos, cartório, padaria e uma mercearia que, em função do crescimento da vizinhança, começou a vender materiais de construção. Diante de outras solicitações de seus moradores atendidas pela Prefeitura e pela perspectiva concreta de construção de um sistema de abastecimento de água tratada, é de se prever a instalação cada vez maior de novas famílias. São mudanças que parecem estar apenas começando a se desenrolar.

Aparentando preocupação com o que vem ocorrendo, não apenas em Caeté mas em outros pontos da zona rural do município que também tem crescido em anos recentes, a prefeitura de Juiz de Fora irá incluir essas áreas nos estudos e proposições do próximo Plano Diretor de Desenvolvimento Urbano a ser elaborado para $2008^{34}$. Mas o papel primeiro dos órgãos de planejamento, que
32 VILLAÇA (2001) aponta o papel crucial do transporte na estruturação do espaço urbano. Lembra porém que essa força "atua dentro de um quadro de relações sociais, as quais, por sua vez, definem as necessidades e condições de deslocamento (2001, p. 180). Feita esta consideração, a referida estrada só recebeu essas melhorias mediante anos de pressão de seus moradores e, como de costume, às vésperas de uma campanha eleitoral.

33 Novamente VILLAÇA (2001, p. 80) faz uma observação que se rebate no atual processo de transformação de Caeté, reforçando o papel estruturante da acessibilidade: "A simples proximidade física de um terreno rural à cidade não o torna potencialmente urbano. É necessário haver acessibilidade, isto é, um sistema de transporte de passageiros a preços compatíveis com os que podem ser pagos pela demanda."

34 Em 1986, com a Lei do Uso e Ocupação do Solo, foram delimitadas as áreas rurais e urbanas do município, sendo nesta última considerados os Núcleos Urbanos dos distritos, ou seja, seus povoados. Para estes, foram definidos tipos particulares de zoneamento que entraram como anexo à referida Lei. De forma muito genérica, ficou definido que nesses núcleos urbanos só poderão ser estabelecidas Zonas Residenciais. Outras zonas autorizadas para esses núcleos, como as Comercial, de Uso Múltiplo e Industrial, poderão ser efetivadas apenas mediante o "parecer favorável da Comissão de Uso do Solo ou quando estiverem vinculadas a planos instituídos pelo Poder Público (Lei 06910 de 31/05/1986). Pela 
Lei do Parcelamento do Solo, na área rural fica permitido apenas o seu parcelamento para fins rurais, também impedindo os parcelamentos que resultem em terrenos de dimensão inferior à do modulo rural da região, estabelecido pelo órgão federal competente (Lei 06908 de 31/05/1986).

35 Neste mesmo sentido LEITE (1991, p. 273 apud BRAGA, 1995, p. 6) informa que: “(...) não se pode assegurar que o plano diretor só deve considerar a zona urbana, a cidade, já que o desenvolvimento desta depende daquela, ou seja, a zona rural. Assim, o Município pode e deve considerar todo o seu território para promover o seu desenvolvimento urbano... O que o município não pode é promover uma política agrária e instituir um zoneamento rural." Também GODOY (1990, p. 218 apud BRAGA, 1995, p. 6) afirma: "No caso específico do plano diretor, por exemplo, é inquestionável o direito da administração municipal dispor da área rural para decidir sobre reserva de mananciais, a fim de garantir o abastecimeento de água, sobre bota fora de lixo domiciliar coletado, sobre áreas de lazer e sobre chácaras de recreio, para ficarmos nos casos mais evidentes. Desta forma, a competência municipal do uso e ocupação do solo rural, fora específica destinação agropecuária, permite condições de incluir, no plano diretor, a área conveniente à atividade decorrente da vida na cidade."VILLACCA (2007), confirma a necessidade de uma visão abrangente do território das cidades, destacando os limites de sua aplicabilidade: "Está fora da alçada municipal dizer onde é pastagem, onde deve ser a lavoura, o tamanho mínimo ou máximo das propriedades é o de orientar a expansão urbana para áreas previamente definidas, é mais uma vez atropelado pela realidade dos fatos. Novamente as diretrizes chegam com atraso, com intuito apenas reparatório, paliativo. O crescimento de Juiz de Fora, obedecendo a uma forma radial, como é frequiente, acabou por criar longos vetores que estimulam uma ocupação esparsa, como a que ocorre entre a cidade e Caeté.

Não há duvidas de que este povoado carece de serviços que podem melhorar as condições de vida de seus moradores. Este é, portanto, um problema a ser solucionado. Mas quando se estende esses serviços a um ponto distante 7 $\mathrm{Km}$ das franjas da cidade, visando atender a um número muito pequeno de famílias, é preciso ter em conta os desdobramentos que se seguirão: não apenas o inchaço daquele povoado mas a ocupação ao longo dos referidos quilômetros de trajeto que também passam a ser objeto de especulação imobiliária, convertendo assim áreas rurais em suburbanas, alqueires e hectares em metros quadrados. Mas a dotação de infra-estrutura a esse povoado em especial, além de benevolentemente atender de modo direto à reduzida comunidade carente, agracia os especuladores de terras, promove visibilidade a políticos às vésperas das eleições e, por fim, justifica a cobrança de impostos pela municipalidade através do IPTU, uma de suas maiores fontes de arrecadação, onde antes se pagava ITR, um imposto federal. Justifica-se por fim a designação de "núcleos urbanos" pela administração pública àqueles povoados rurais, ao menos à Caeté, agora com ares de urbanidade.

Não se questiona aqui a indispensável a abrangência do Plano Diretor a esses povoados, que conformam com a cidade um conjunto articulado ${ }^{35}$. A presença da vida rural nos municípios da Mata Mineira, para ficar apenas nesse contexto 
próximo, é significativa o bastante para justificar sua efetiva inclusão na alçada de preocupações dos instrumentos de planejamento municipais. É preciso apenas que os planos para esses locais levem em conta suas especificidades, já que não são típicos bairros periféricos.

As demais áreas dos distritos, representadas pelas propriedades rurais, ficam sob a tutela do INCRA, da esfera federal. Sobre essas propriedades o mais significativo instrumento de ordenação ou, mais especificamente, de restrição ao uso do solo, é o Código Florestal ${ }^{36}$, basicamente orientado para proteção dos solos e dos recursos hídricos, tendo como seus principais dispositivos a Reserva Legal (RL) e a Área de Preservação Permanente (APP) $)^{37}$.

Sarandira, como será detalhado no capítulo seguinte, possui relevo muito movimentado, com morros e encostas íngremes, abundância de nascentes e, com elas, de pequenos cursos d'água. São essas as características que, de acordo com a lei, condicionam as maiores restrições ao uso da terra representadas pelo dispositivo das APPs, classificando estas extensas áreas como incompatíveis com as atividades agropecuárias, ou mesmo florestais, ali desenvolvidas.

O quase completo descumprimento desta legislação na região, principalmente no que se refere às APPs, resulta da dificuldade de interpretação do Código Florestal em seu emaranhado de determinações, sua inflexibilidade, a desconsideração de suas particularidades sócio-ambientais e também seu caráter mais restritivo do que propositivo, onde faltam alternativas economicamente viáveis para seu efetivo cumprimento. Fatores que, por fim, corroboram para a diminuição de sua eficácia ${ }^{38}$.

Assim, pela estrita interpretação da lei estariam todos cometendo crimes etc. Contudo, o uso urbano do solo rural, por exemplo, poderá ser regulado pelo município a hora que quiser. O que há ao longo das rodovias: posto de gasolina, restaurante, motel, tudo isso o município pode zonear por ser uso urbano mas localizado na zona rural."

${ }^{36}$ Tratado nos capítulos 4 e 5 .

${ }^{37}$ Reserva Legal é a área averbada em cartório correspondente a no mínimo 20\% (para todo o território nacional, exceto a Amazônia Legal) das terras de todas as propriedades maiores que um módulo rural a serem mantidas ou reflorestadas. As demais áreas a serem preservadas, são as Áreas de Preservação Permanente (APPs), representadas na região pelos topos de morro, escarpas com declividade superiores a $45^{\circ}$ e também ao redor das nascentes e cursos dágua. Estes itens também tratados no capítulo 4.

38 Citando AB'SABER (1996), FRANCO (p.17, 2000) comenta que para aquele autor, todas as legislações ambientais foram feitas antes de existir uma consciência ambiental ecológica, de modo que o que tem de bom foi por intuição e o que tem de ruim foi por falta de conhecimento técnico na época. (...) AB'SABER ainda apontaria como principal problema nas legislações ambientais a falta de noções de escala, de volume e de regionalidades. 
ambientais. E neste sentido, os ainda incipientes mecanismos colocados em prática em 2006, com a aprovação da Lei da Mata Atlântica, que estabelecem não apenas restrições à descaracterização deste bioma mas também incentivos aos produtores rurais interessados na recuperação ambiental, permanecem totalmente desconhecidos pelos proprietários de terras em Sarandira.

Desta forma, as restrições legais quanto ao uso do solo, que implicariam a manutenção de áreas florestadas, pouco influenciaram a fisionomia da paisagem local. 


\section{CAPÍTULO}

3 


\section{3 - A paisagem de Sarandira}

A paisagem do distrito de Sarandira vem sendo notadamente moldada por quase três séculos de trabalho humano voltado à produção de gêneros agropecuários, e pela realização das atividades sociais a ela atreladas.

Sua decomposição em elementos estritamente naturais e aqueles rigorosamente transformados pelo homem não é viável, verificando-se uma estreita ligação entre ambos. Mas, embora não possam ser tomados, a rigor, como naturais, inegavelmente sobressaem no campo processos biológicos.

Assim, sua paisagem decorre tanto da subordinação da natureza ao trabalho que vem sendo empreendido, limitado pelas técnicas e tecnologias disponibilizadas e pela força de trabalho empregada, quanto da adequação desse modo de fazer às condicionantes ambientais.

Sem perder de vista estas complexas interações, a caracterização da paisagem local se dá inicialmente, neste capítulo, pela consideração, em separado, dos seus patrimônios de ordem natural e cultural.

Foram então descritos seus elementos biofísicos e arquitetônicos aglutinados pelo patrimônio intangível de sua culura popular. Posteriormente foram tomados em conjunto e em suas inter-relações, possibilitando uma síntese, a leitura da paisagem local. 


\subsection{Meio biofísico}

Embora esta paisagem rural, quando comparada à cidade, conserve marcas mais efêmeras de sua apropriação, seria enganoso pensar que estamos diante de um ambiente pouco alterado pelo homem, como atestam a conversão de sua superfície florestada por lavouras e pastagens e a intrusão de uma fauna domesticada em meio à outra, autóctone. Mas nem por isso seu valor ecológico se perdeu por completo. Pelo contrário. Constitui ainda um importante repositório de fauna e flora nativos, dignos de medidas que assegurem sua preservação.

Neste sub-capítulo, seu meio biofísico é descrito através da conjugação de um olhar sensível e um olhar analítico. Decompondo-o em fatores abióticos ("Mares de morros", sub-item 3.1.1) e bióticos ("Flora e Fauna", sub-item 3.1.2), procurou-se apresentar as relações entre os elementos mais importantes e facilmente perceptíveis da paisagem, a despeito dos pequenos recursos disponíveis diante da complexidade dos processos ecológicos em questão. São interpretações resultantes da consulta a escassas, e muitas vezes genéricas, descrições científicas, confrontadas com constatações empíricas e saberes populares locais. 
39 Pela classificação de Aziz Ab`Saber, mares de morros florestados representam um dos seis domínio morfoclimáticos brasileiros, uma área extensa disposta ao longo de todo o Brasil Tropical Atlântico, que recebeu seu nome em função do aspecto de seu relevo ondulado, decorrente principalmente da erosão causada pelas chuvas.

40 Saint-Hilaire (1974, p. 20-21), em suas andanças pelo Rio de Janeiro em 1822, registrou que "vargem" é o nome dado pelos brasileiros em geral a "todas as planícies úmidas que se encontram entre montanhas, nos lugares de mata virgem. São vales muito largos ou o ponto de encontro de muitos vales." Na região de Sarandira também costuma-se dizer "varge", esta também como variação da palavra várzea.

\subsubsection{Mares de morros}

Sarandira está localizada na Unidade Serrana da Zona da Mata, pertencente à Região Mantiqueira Setentrional, situada a $21^{\circ} 50$ de latitude sul e $43^{\circ} 12$ de longitude oeste. Possui um relevo muito movimentado e característico dos domínios de mares de morros ${ }^{39}$ onde está inserido, representando, junto a todo o município, os contrafortes da Serra da Mantiqueira ao norte.

Cortam de forma difusa esse perfil numerosos corpos d'água, formadores de parte das duas bacias hidrográficas principais pertencentes ao distrito, as bacias dos rios Paraibuna, a oeste, e Cágado a leste. Este último, a rigor, um afluente do primeiro, que a ele se une apenas fora do território municipal.

Os pontos mais elevados são formados por serras dispostas paralelamente umas às outras, estendendo-se no sentido sudoeste-nordeste e chegando a atingir em alguns pontos 900 metros de altura. Este perfil cria importantes marcos na paisagem, por vezes apresentando faces de rochas nuas, que por suas formas mais irregulares contrastam com o cenário quase homogêneo de morrotes arredondados ou "meias-laranjas", como costuma-se dizer por lá. Nos fundos de vale, ou vargens ${ }^{40}$, as menores altitudes giram em torno dos 600 metros.

Cerca de $70 \%$ de sua área é montanhosa, e menos de $20 \%$ pode ser considerada plana. Essa topografia acidentada tem representado um grande entrave às atividades agropecuárias. As encostas íngremes, por não serem tratoráveis, acabam inviabilizando a maioria das culturas. Já as áreas planas, por encontrarem-se basicamente em locais brejados, muito próximos do lençol 
freático, são igualmente restritivas. Essas características acabam estimulando a pecuária como principal atividade na maioria das propriedades rurais, já que a utilização do solo como área de pastagem requer menores cuidados. Para o plantio das forrageiras recorre-se à aração e plantio mecanizados em linhas verticais, morro abaixo, tarefa arriscada e comumente destinada apenas a tratoristas muito experientes. Mas há ainda locais de tamanha declividade que só permitem o plantio manual, no sistema de "covinhas", serviço muitas vezes empreitado por turmas de trabalhadores itinerantes.

Naqueles locais até o gado tem dificuldade em se estabilizar, e como muito esforço é empreendido em sua locomoção, seu ganho de peso é retardado, tornando menos rentável a sua criação. Não raro se ferem ou morrem ao cair de ribanceiras, em especial sobre as frágeis extremidades dos taludes íngremes formados pela abertura de estradas. A exploração das saibreiras locais é outra preocupante frente de degradação ambiental, tendo já contribuído para a formação de enormes voçorocas.

Sobre as restrições impostas pelo relevo característico da região sudeste do país, e que é tão evidente na paisagem do Distrito de Sarandira, AB'SABER (2003, p. 19) escreveu:

O domínio de "mares de morros" tem se mostrado ser o meio físico, ecológico e paisagístico mais complexo e difícil do país em relação às ações antrópicas. No seu interior tem sido difícil encontrar sítios para centros urbanos de uma certa proporção, locais para parques industriais avantajados (...) como igualmente tem sido difícil e muito custosa a abertura, o desdobramento e a conservação de novas 
estradas no meio dos morros. Trata-se, ainda, da região sujeita aos mais fortes processos de erosão e de movimentos coletivos de solos em todo o território brasileiro.

O acidentado relevo local, desprovido de cobertura vegetal arbórea, aliado à alta pluviosidade da região, é responsável por uma intensa dinâmica superficial. Somam-se a isso práticas inadequadas de manejo que remontam às lavouras itinerantes indígenas, e que se tornaram ainda mais exemplares no início do século XIX, quando a vaga cafeeira chegava à região. Esta passou a ocupar todas as colinas, dispondo suas fileiras inadvertidamente em linhas perpendiculares às curvas de nível, técnica empregada por permitir ao patrão e seus encarregados vistoriarem à distância as atividades feitas na lavoura, possibilitando uma melhor visualização dos trabalhadores, além da facilidade de escoar a produção e proceder aos demais tratos morro abaixo. Tudo isso contribuiu para o carreamento de sua matéria fértil, fator que veio a acelerar sua decadência.

Ainda que em menor escala, processo semelhante se dá atualmente, com o preparo do solo para a formação dos pastos, acarretando erosões ao longo dos meses chuvosos, além do assoreamento dos córregos. Também outro importante fator de degradação é resultado do sobrepastejo e do pisoteio do gado que, formando trilhos compactados no solo, dificultam a infiltração das águas superficiais e, portanto, a recarga dos aqüíferos. 


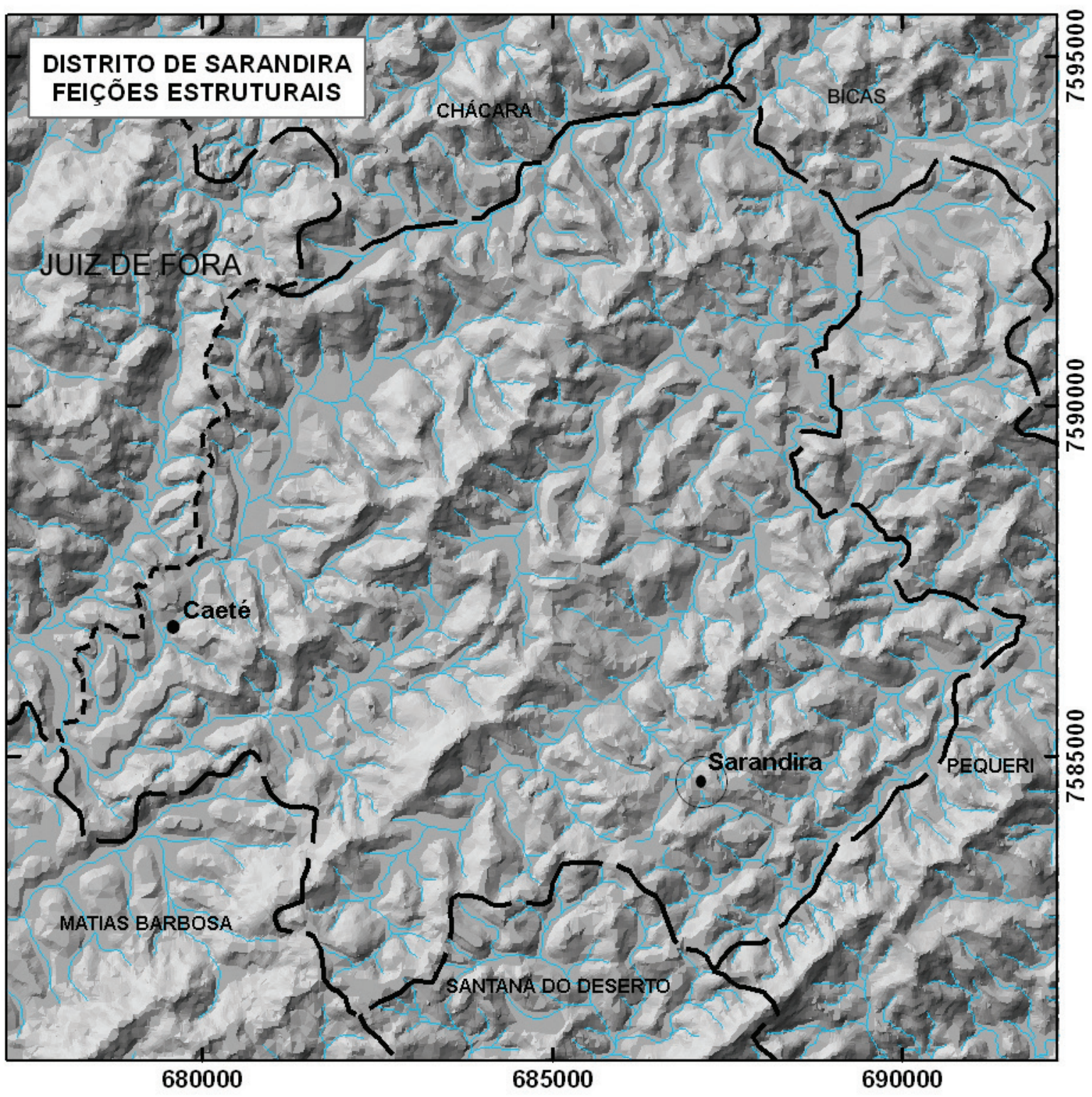

\section{LEGENDA}

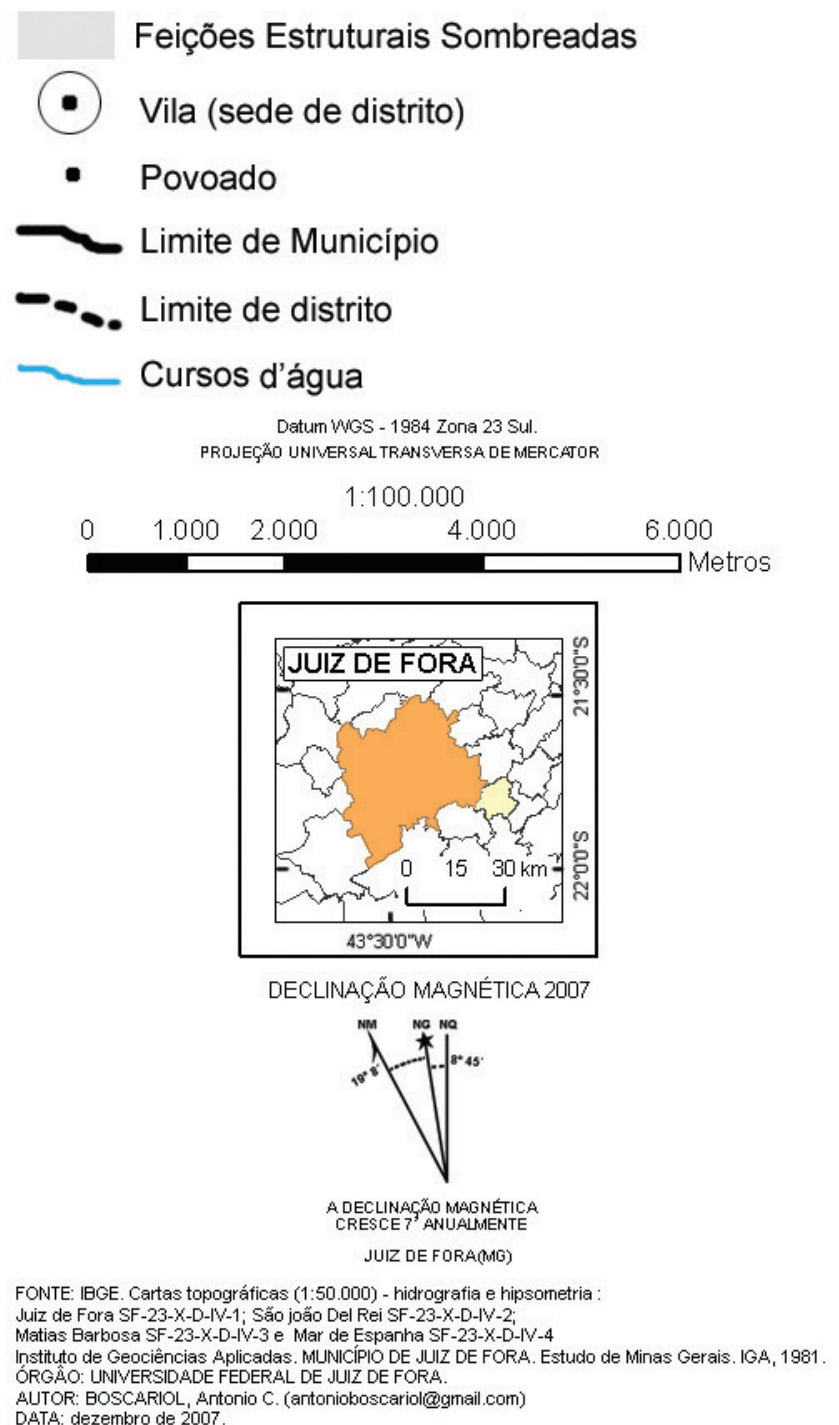




\section{LEGENDA}

\section{Elevaçäo}

$500-1000$

$800-900$

$700-800$

$600-700$

$500-600$

$480-500$
(-) Vila (sede de distrito)

- Povoado

L Limite de Municipio

-. Limile de distrito

Cursos d'água

Cortes nas Feiçōes Estruturais - Perfis

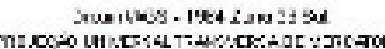

$1: 1060: 0$
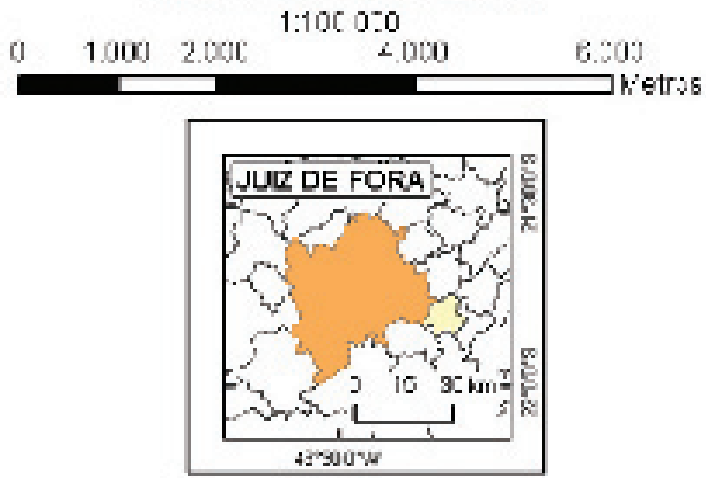

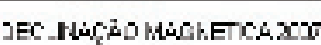

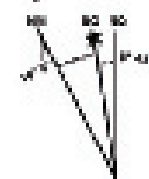

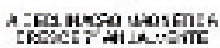

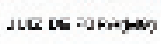

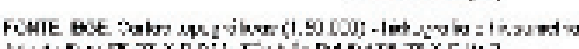

Hets

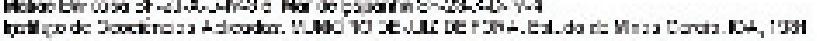

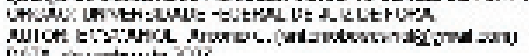

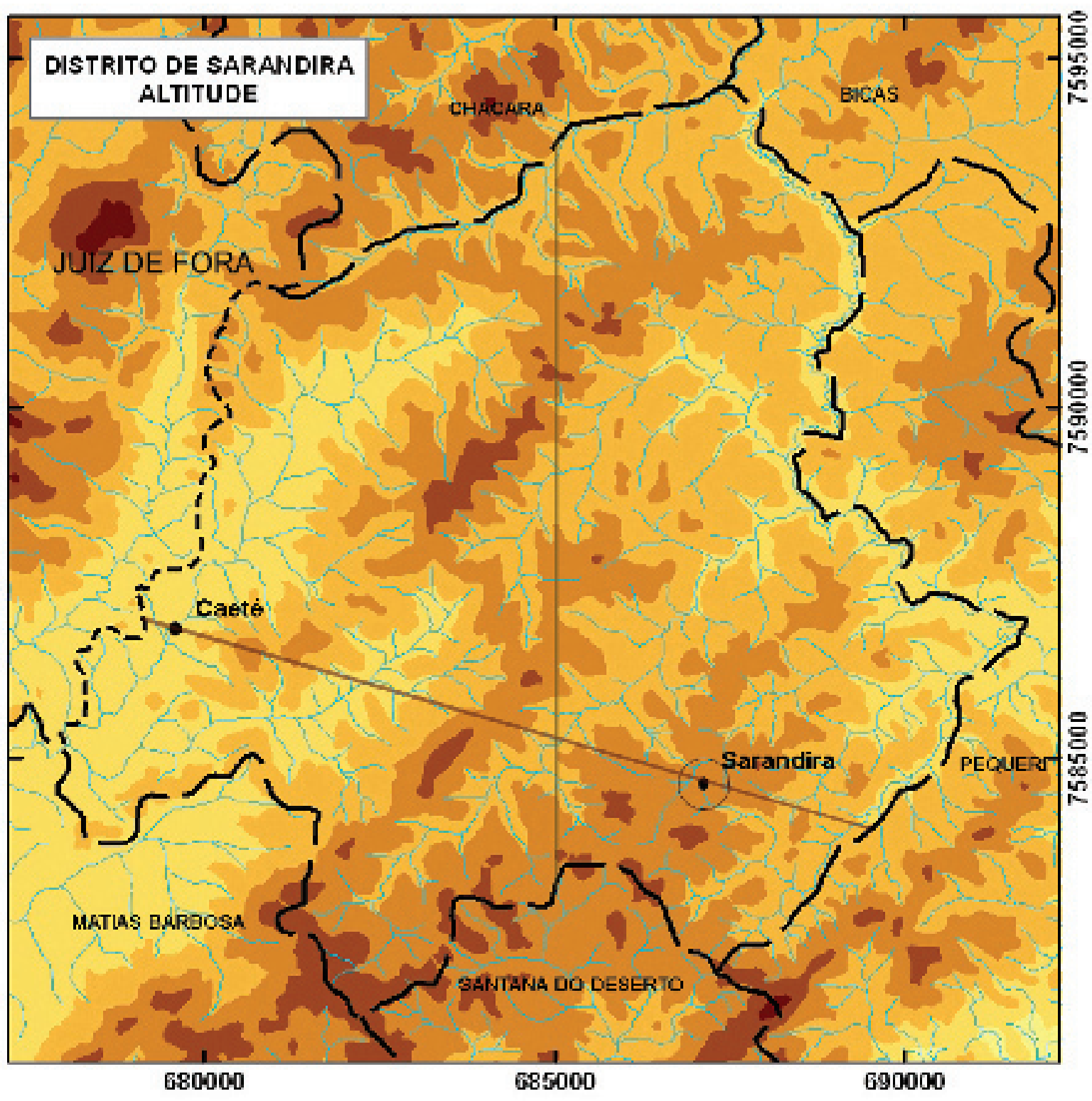




\section{PERFIS TOPOGRÁFICOS}

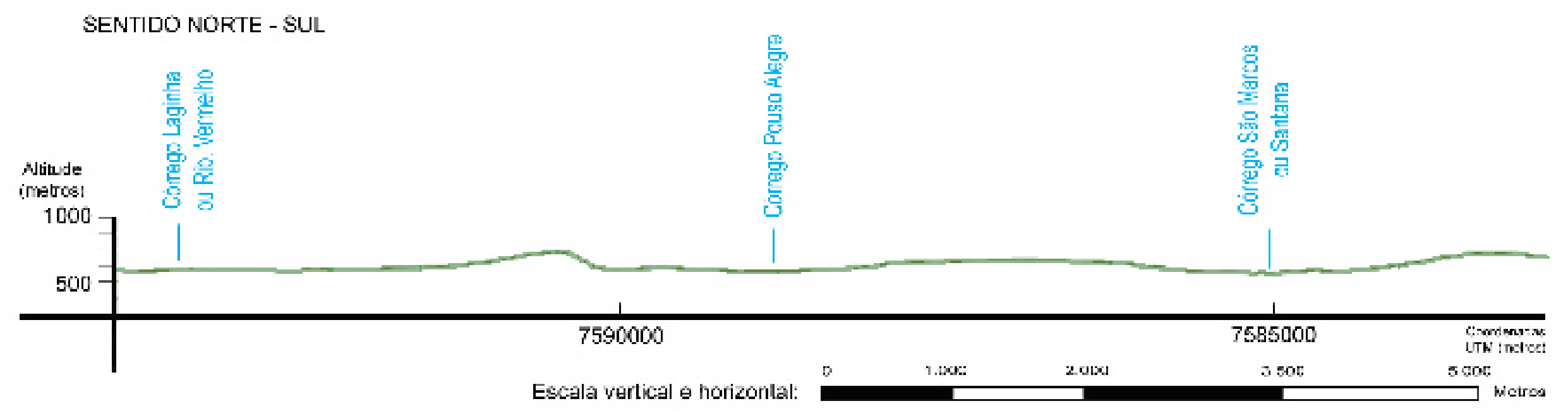

SENTIDO CAETE - SARANDIRA

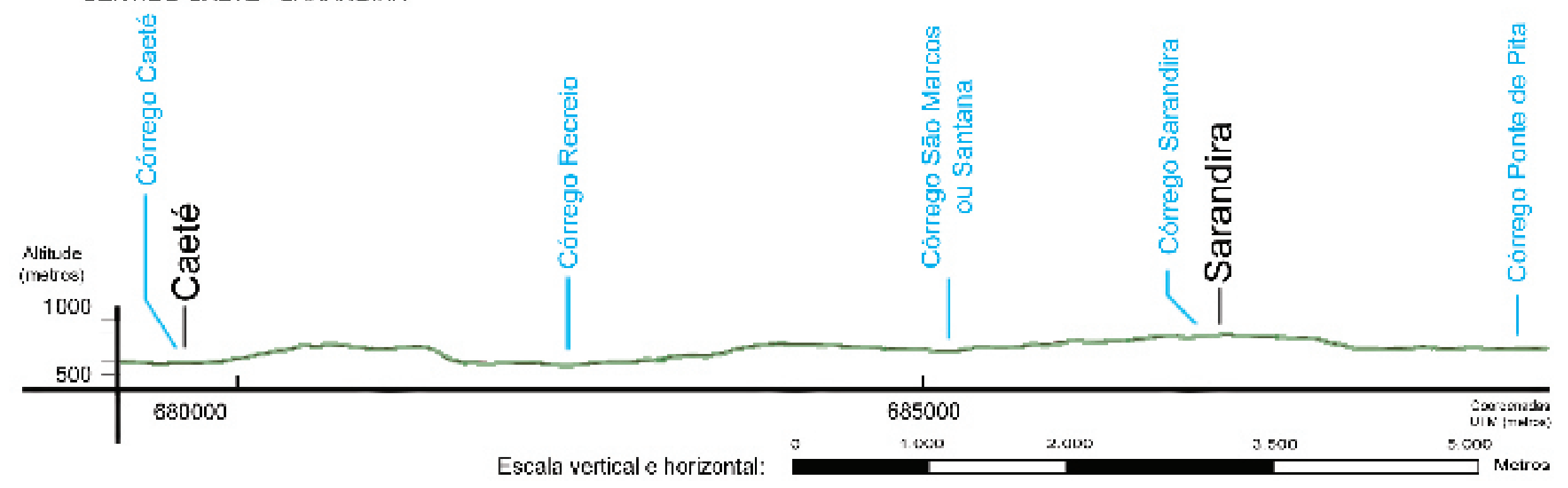




\section{LEGENDA}

\section{DECLIVIDADE}

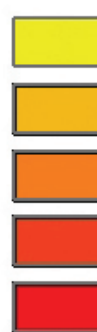

$0 \%-15 \%$

$16 \%-30 \%$

$31 \%-45 \%$

$46 \%-60 \%$

$61 \%-75 \%$
- Vila (sede de distrito)

- Povoado

Limite de Município

- Limite de distrito

C Cursos d'água

Datum WGS - 1984 Zona 23 Sul.

$1: 100.000$

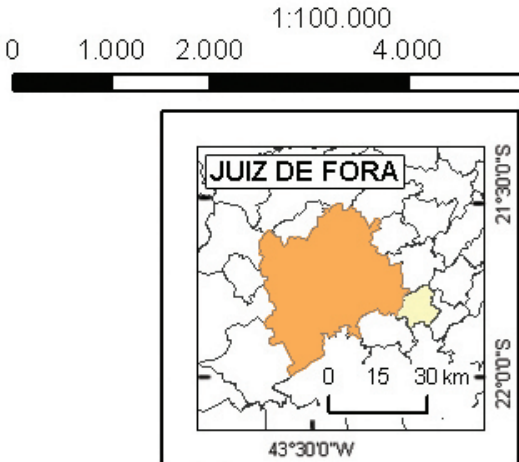

DECLINAÇÃO MAGNÉTICA 2007

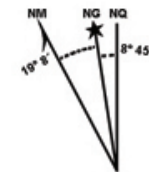

ADECLNACAO MAGNGICA
CRESCE? ANUALMENTE

JUIZ DE FORAMMG)

FONTE: IBGE. Cartas topográficas (1:50.000) - hidrografila e hipsometria :

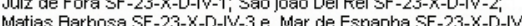

Instituto de Geociências Aplicadas. MUINICIFIO DE JUIZ DE FORA. Estudo de Minas Gerais. IGA, 1981 ORGAO: UNIVERSIDADE FEDERAL DE JUIZ DE FRRA.
AUTOR: BOSCARIOL, Antonio C. (antonioboscariol@ggnail.com)

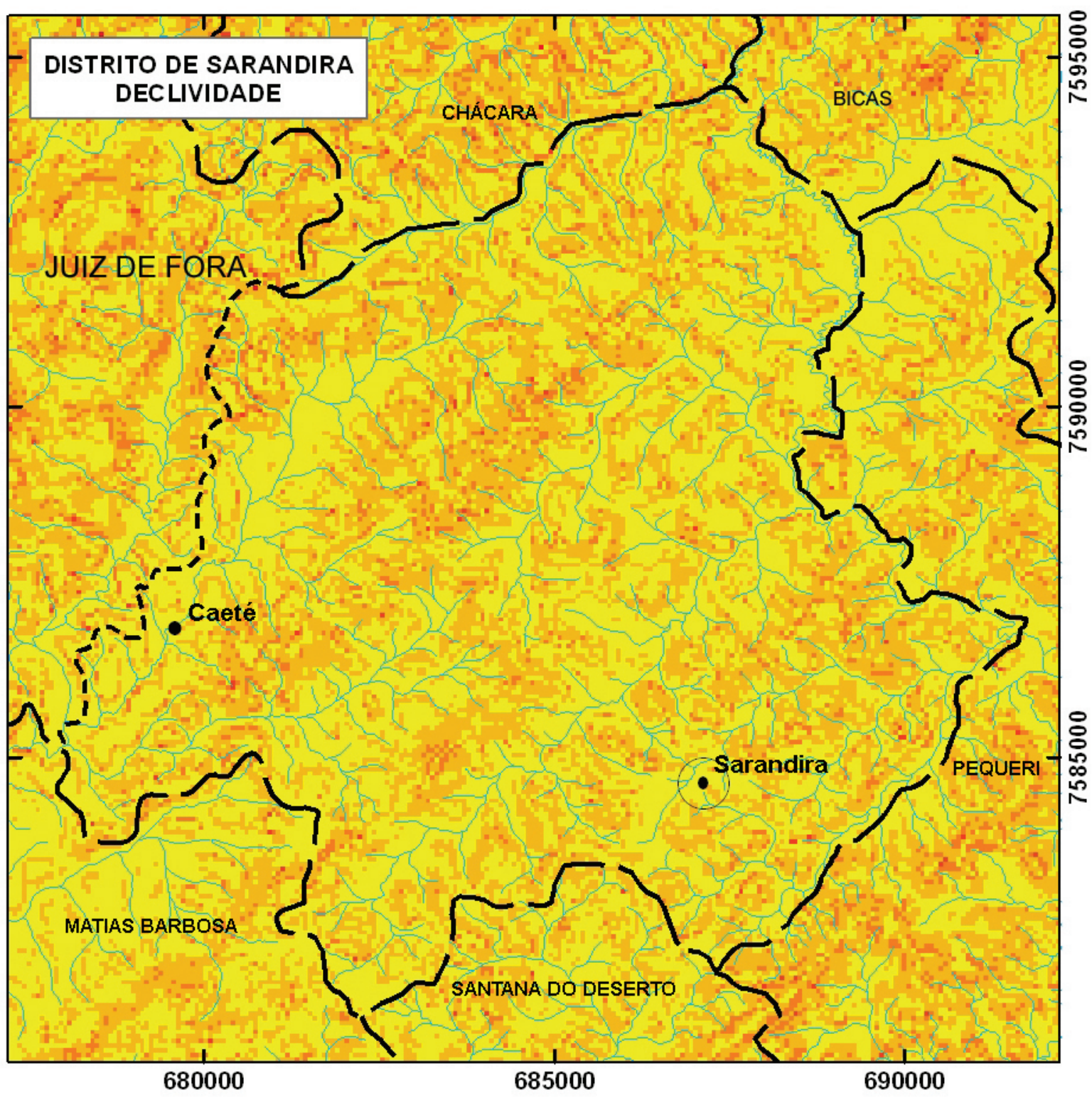


A vida nesta zona rural, as interações ecológicas que unem bichos, plantas e homens, são também pautadas por outro importante componente do meio biofísico, o clima. A influência das estações secas e chuvosas determina um calendário surpreendentemente preciso das atividades a serem realizadas, condicionando também a paisagem característica de cada uma das estações que se sucedem ${ }^{41}$.

Juiz de Fora, segundo a classificação de W. Koppen apresenta clima predominantemente mesotérmico, ou Cwa, com duas estações bem definidas: uma de verão brando ou moderadamente quente e úmido, que vai de outubro a abril, e a de inverno, mais frio e seco, que vai dos meses de maio a setembro. Por corresponder a um tipo tropical influenciado por seu relevo, que apresenta altitudes médias situadas entre 600 e 900 metros, que contribuem para a amenização das temperaturas, é também chamado Tropical de Altitude (Juiz de Fora - Prefeitura Municipal, 1996).

Os índices pluviométricos verificados nas últimas décadas no município giram em torno dos $1.536 \mathrm{~mm}$ anuais. No mês de janeiro é registrada a maior média, com $298 \mathrm{~mm}$, enquanto que a temperatura oscila por volta dos $18,9^{\circ} \mathrm{C}$. Fevereiro, o mês mais quente, possui temperaturas próximas de $21,7^{\circ} \mathrm{C}$ e julho, o mais frio, 16, $1^{\circ} \mathrm{C}$. (UFJF - ECP, 1973 - 1995). A umidade relativa situa-se em torno de 77\% (UFJF, 2000). O distrito de Sarandira, dado seu afastamento da concentração urbana da área central, e portanto da mancha de calor a ela associada, tende a um clima mesotérmico do tipo Cwb com verões mais brandos.

Nos meses de frio a pastagem fica seca, a vegetação torna-se pálida e a água das nascentes e cursos escassea. O céu é tomado por um azul intenso, limpo. Os dias ficam mais curtos e a temperatura cai bruscamente à medida que o sol
41 Em linhas gerais, de acordo com STAICO (1976), o clima é responsável pelas chuvas, temperaturas, umidade do ar, ventos, pressões, evaporações, insolações e nebulosidades, definindo em boa parte as características da vegetação e do solo locais, sendo também importante para o estudo da hidrologia. 

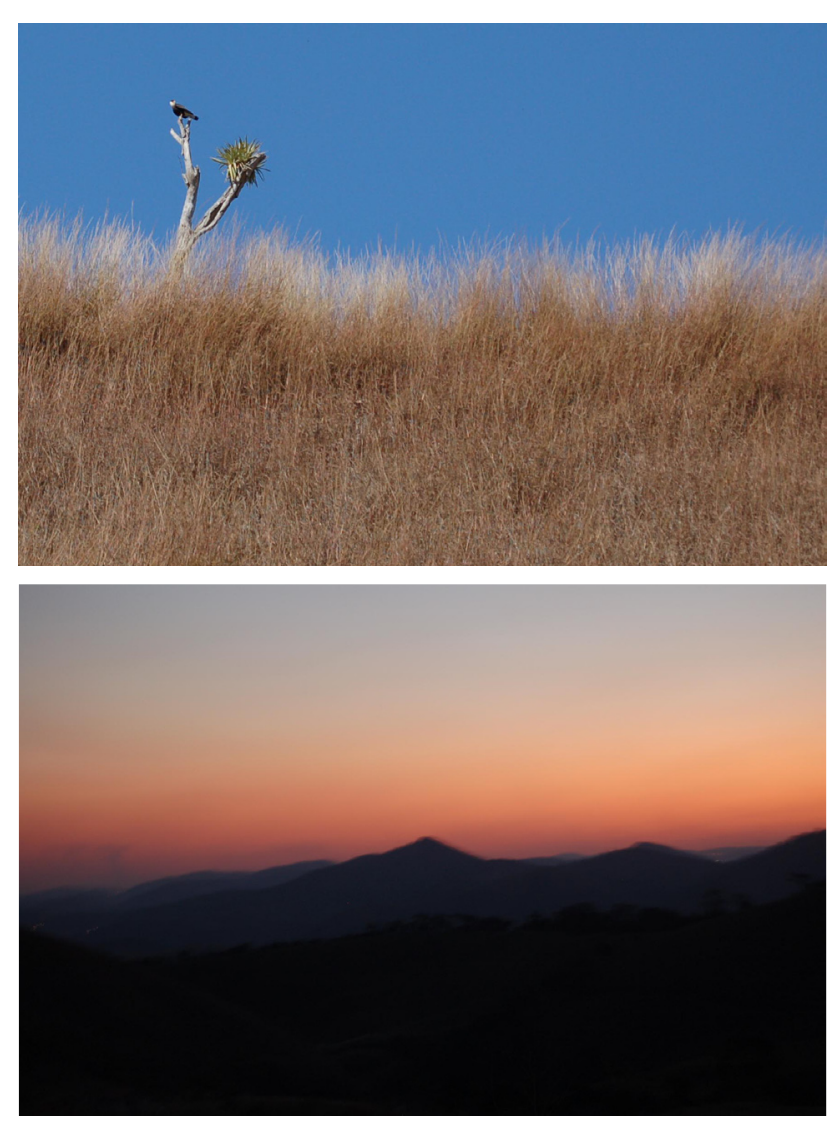

No alto, o carcará à espreita de comida em meio ao capim gordura ressecado, na Fazenda Boa Vista. Abaixo, o perfil do seu relevo contrastado com o céu alaranjado do cair da noite. Imagens típicas do inverno na região. Crédito: Autor vai se escondendo, e o céu começa a ser riscado, na altura do horizonte, por tons de rosa e laranja, cores que ficam ainda mais acentuadas com o progresso das queimadas tão comuns nessa época do ano, especialmente no mês de agosto.

Com a chegada da noite, uma profusão de estrelas se torna visível, e quando é lua cheia, a claridade por ela refletida permite que se caminhe seguramente pelas estradas, evitando-se pedras e buracos. Com o passar das horas, o efeito da trajetória lunar sobre o perfil acidentado das serras cria um espetáculo curioso, alternando luzes e sombras, sutilmente cobrindo a paisagem com graduações escurecidas do azul.

Ao amanhecer são freqüentes os fenômenos de inversão térmica, que aprisionam a cerração nos pontos de cota mais baixa, tornando momentaneamente obstruída a visão da paisagem. Como descreveu STAICO (1976, p.129) sobre Juiz de Fora:

\begin{abstract}
As madrugadas e manhãs são frias, acentuadas pela inversão de temperatura, fenômeno que é sentido de modo especial em virtude do relevo movimentado e porque ocupa os vales utilizados para fixação humana. Os baixos stratus cobrem, então, com manto espesso e alvo de nevoeiros, os terrenos deprimidos onde estão a cidade, vilas, fazendas e sítios. À proporção que o dia vai esquentando, a neblina se desfaz e sobe para formar stratocumulus.
\end{abstract}

Com os campos secos, a disponibilidade de alimentação para o gado é reduzida, podendo ser complementada com a silagem de cana preparada nos meses 
anteriores. As criações e animais domésticos passam mais tempo parados, poupando energia. A fauna nativa se esconde.

Essa paisagem contrasta em muito com a do período que se inicia a partir do final de setembro, com a chegada da primavera e das primeiras chuvas, que se estendem pelos seis meses seguintes. É quando a cobertura vegetal que antes se encontrava em estágio de dormência, com muitas espécies desfolhadas, retoma seu crescimento vigoroso, e as novas brotações trazem consigo o verde em diversos matizes. Nesta época aproveita-se para iniciar o tradicional plantio do milho e do "feijão das águas". Os dias tornam-se mais longos e a temperatura sobe, apresentando menores variações.

Nos meses de dezembro, janeiro e fevereiro atingem-se os maiores índices de precipitação e o céu parece permanentemente carregado, mesmo quando há poucas nuvens. Os efeitos do mormaço são agravados pela alta umidade e escassez de ventos, e a maioria das criaturas se refugia à sombra. Típicas dessa época são as chamadas chuvas de verão, caracterizadas por sua curta duração e forte intensidade, caindo principalmente ao final da tarde e início da noite. Tempestades são comuns, acompanhadas de vendavais que já destelharam e mesmo derrubaram algumas casas. Raios, por lá também chamados "faíscas", cortam o céu e, por conta deles, árvores e reses acabam morrendo ${ }^{42}$.

Com as chuvas, o nível dos ribeirões sobe, a ponto de por vezes extrapolarem suas calhas passando a ocupar grandes extensões na várzea, podendo constituir novos traçados ou formar brejos temporários. Barragens de alguns açudes são rompidas e deslizamentos de terra são constantes. A circulação de veículos pelas estradas enlameadas torna-se muito difícil, e a queda de barreiras um evento rotineiro. O caminhão do leite não consegue chegar até os retiros, o que acarreta
${ }^{42}$ As árvores isoladas nos pastos costumam receber descargas elétricas que vão se dissipar em círculos concêntricos sobre uma área relativamente pequena, dada a baixa condutividade do solo. Abrigado sobre a árvore no momento da descarga, o gado é submetido a uma drástica variação de corrente, com efeitos mais devastadores quanto maiores as dimensões do animal.

Uma antiga referência sobre os raios no município é o diário de viagem do ouvidor Caetano da Costa Matoso (COSTA MATOSO, 1999, p. 889-897), que passou por Juiz de Fora no ano de 1749, relatando seu temor de que ainda pudesse ser surpreendido em sua jornada através da floresta por fortes trovoadas como as que enfrentara nos dias anteriores.

Por fim, a incidência de raios em Minas Gerais, segundo VISACRO FILHO (2005), é uma das maiores do mundo. Precisamente o dobro da média mundial, que é de duas descargas por $\mathrm{km}^{2} / \mathrm{ano}$. Destaca-se nessa estatística a cidade de Juiz de Fora, com media anual de dez raios por $\mathrm{km}^{2}$. 

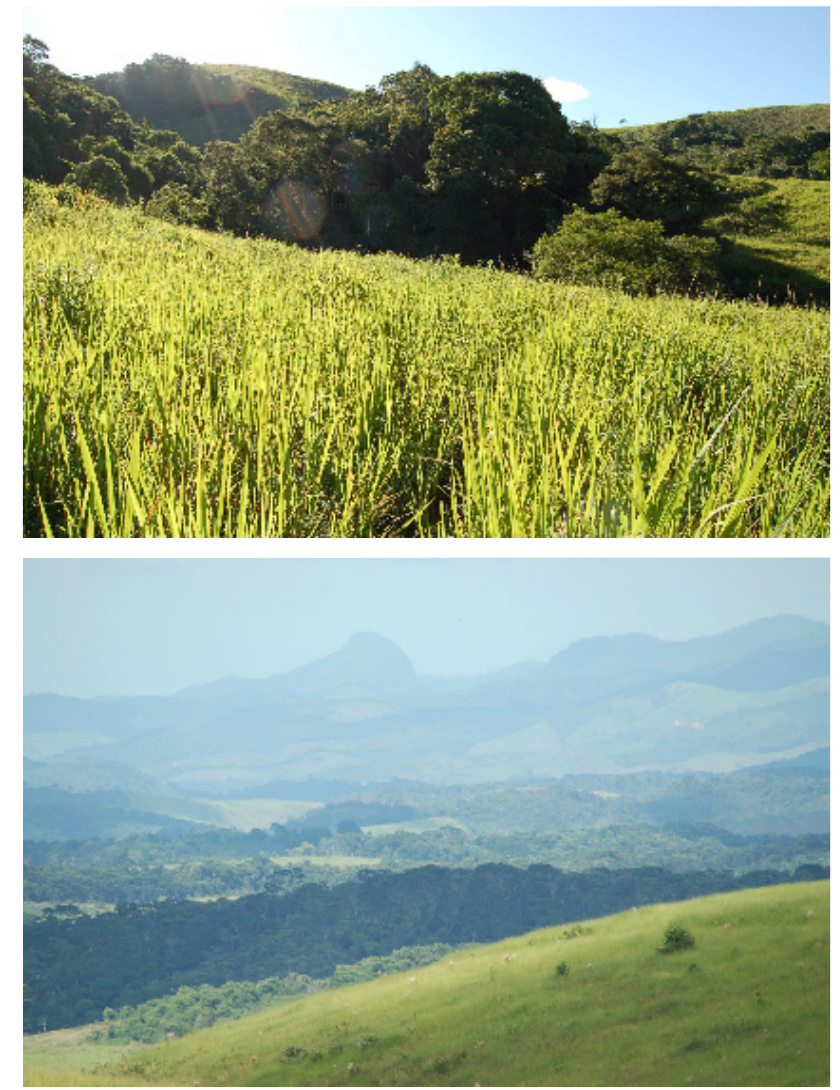

Dias de verão no distrito: pastos verdes e paisagens turvas. Crédito: Autor

43 Referência ao dia de São José, 19 de março, quando tradicionalmente se planta alho.

${ }^{44}$ Nasce em Antônio Carlos, próximo à Ibitipoca, e percorre $166 \mathrm{~km}, 32$ deles por Juiz de Fora até desaguar à margem esquerda Paraíba do Sul, divisa com o estado do Rio de Janeiro. a perda da produção. Conforme a sabedoria popular, este período encerra-se em meados de março com a "enchente das goiabas", também conhecida como "enchente de São José"43.

Os ventos dominantes são provenientes do quadrante norte, rumando para sudoeste à medida que se chocam e se alinham com as suas principais serras, vindo por fim a assumir inúmeras direções à medida que encontram acidentes geográficos menores, estabelecendo, a cada escala que se avalia, um microclima particular. Ganham assim mais velocidade quando afunilados nos estreitos vales, vindo por fim a transpor ruidosamente as barreiras representadas pelas cabeceiras das bacias hidrográficas. Também por isso, por lá não se vê construções no alto dos morros, devassadas, localizando-se exclusivamente no limite entre as várzeas e os piemontes, onde os efeitos dos ventos são menos intensos, e tanto a ligação com as estradas quanto o abastecimento de água são facilitados.

Também cortam seu relevo não apenas as ventanias, mas miríades de pequenos corpos d'água que se avolumam nas cotas baixas, formando seus ribeirões.

Juiz de Fora, como um todo, está inserida na Bacia do Rio Paraibuna, que nasce na Serra da Mantiqueira, a aproximadamente $1.200 \mathrm{~m}$ de altitude ${ }^{44}$. Juntamente com os rios Muriaé e Pomba é tributário do Rio Paraíba do Sul, por onde escoam as águas de parte dos estados de São Paulo, Minas Gerais e Rio de Janeiro. Tem como seus principais afluentes os rios Peixe, a oeste, e Cágado, a sudeste, de forma que considera-se a cidade formada por essas três bacias principais. Segundo STAICO (1976), sua rede de drenagem é marcada pela forma dendrítica (ramificada e confusa), com um número grande de afluentes e subafluentes, não muito extensos, que se desenvolvem por todas as direções. 
As terras do Distrito de Sarandira, especificamente, compreendem partes de duas bacias. Pouco mais de um terço de sua superfície ocidental é drenada no sentido nordeste-sudoeste, com suas águas juntando-se às do Paraibuna já no município de Matias Barbosa. Separado desta bacia por uma serra com elevações que atingem 900 metros de altura, as demais águas superficiais escoam no sentido sudoeste-nordeste encontrando o Rio Cágado, que define o limite nordeste do município com seus vizinhos Bicas e Pequeri.

A respeito da qualidade de seus recursos hídricos, é significativo o fato de que toda água que corta Sarandira tem origem no interior de seus limites políticoadministrativos, o que o mantém relativamente bem isolado de fontes externas de contaminação hídrica, ainda que, com as chuvas, parte dos produtos químicos utilizados na agropecuária e também dejetos dos bovinos sejam carreados para os córregos. Por cerca de $11 \mathrm{~km}$, o rio Cágado tangencia sua extremidade nordeste, depois de atravessar a pequena cidade de Chácara, situada ao norte ${ }^{45}$. Mas, à exceção das águas superficiais, os aqüíferos subterrâneos dificilmente podem ser afetados pelas fontes poluidoras existentes na região.

Acima de tudo, são notáveis a qualidade e a abundância de suas nascentes, mesmo nos períodos mais secos. Constitui este recurso um fator importante na valorização daquelas propriedades rurais, sendo, juntamente com a terra, a maior riqueza de que dispõem seus proprietários.

Alocada no interior do lençol freático que acompanha a ondulação das colinas, a água se revela apenas em seus sopés, na forma de nascentes ou "olhos d'água". Nesse ponto, para o abastecimento das benfeitorias, costuma ser captada em um pequeno reservatório e conduzida por mangueira plástica ${ }^{46}$, alimentando a caixa d'água. Assim, após atender seu propósito, ela é escoada por tubulação,
45 Sobre a bacia do rio Cágado, que abarca boa parte do Distrito de Sarandira, STAICO (1976, p. 205-206) faz uma observação que merece atenção: "O território municipal por ele banhado pertence, na maioria, justamente à zona de depressão representada pelo distrito de Sarandira que, aliada à localização geográfica (fora da rota dos ventos dominantes) em relação ao grande núcleo urbano de Juiz de Fora, lhe dá condições de ser encarado como o setor ideal para instalação de indústrias pesadas e poluentes."

Ainda que essa recomendação tenha já mais de 30 anos, e nada naquele sentido tenha se concretizado, permanece o incômodo: quais os efeitos da instalação de uma indústria potencialmente poluidora numa área que mantém relativamente bem preservado seu ambiente natural? Quais as consequiências negativas que isto poderia trazer para os moradores locais e sua produção?

${ }^{46}$ No passado, antes da existência das mangueiras plásticas enterradas, localmente conhecidas por "marias-pretas", a condução da água era feita por bambus ou troncos de imbaúbas, abertos no sentido longitudinal e elevados do chão. 


\section{LEGENDA}

Sub-bacia do Rio Paraibuna

Sub-bacla do Rlo Cagajo

- Vila (sede de distritoi

- Povoado

L Limite de MLnic|plo

- Limite de distriț

— Cursos d'àgua

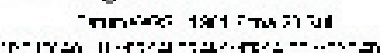
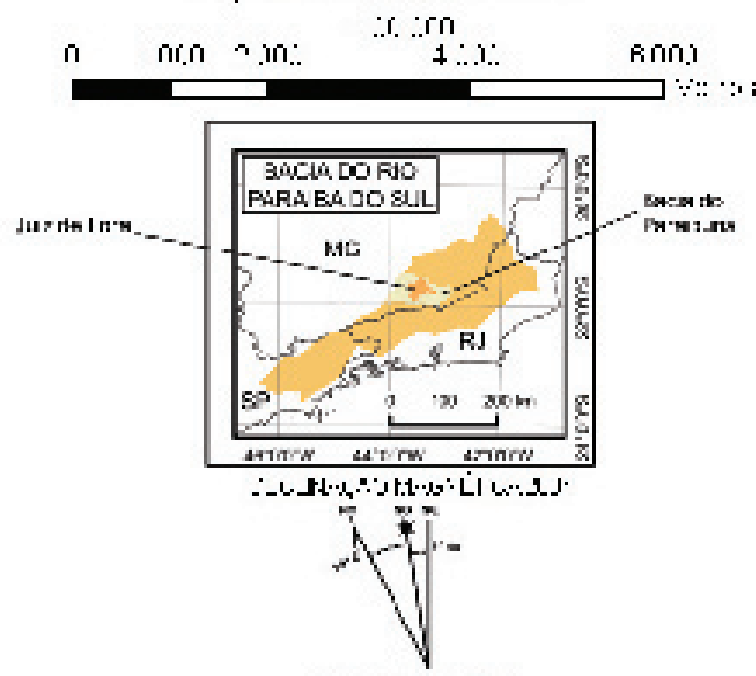

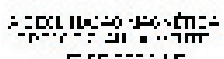

atr-A

Gor

bo:

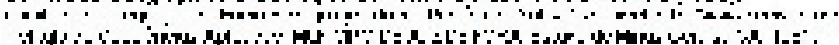

nition

ב.t.

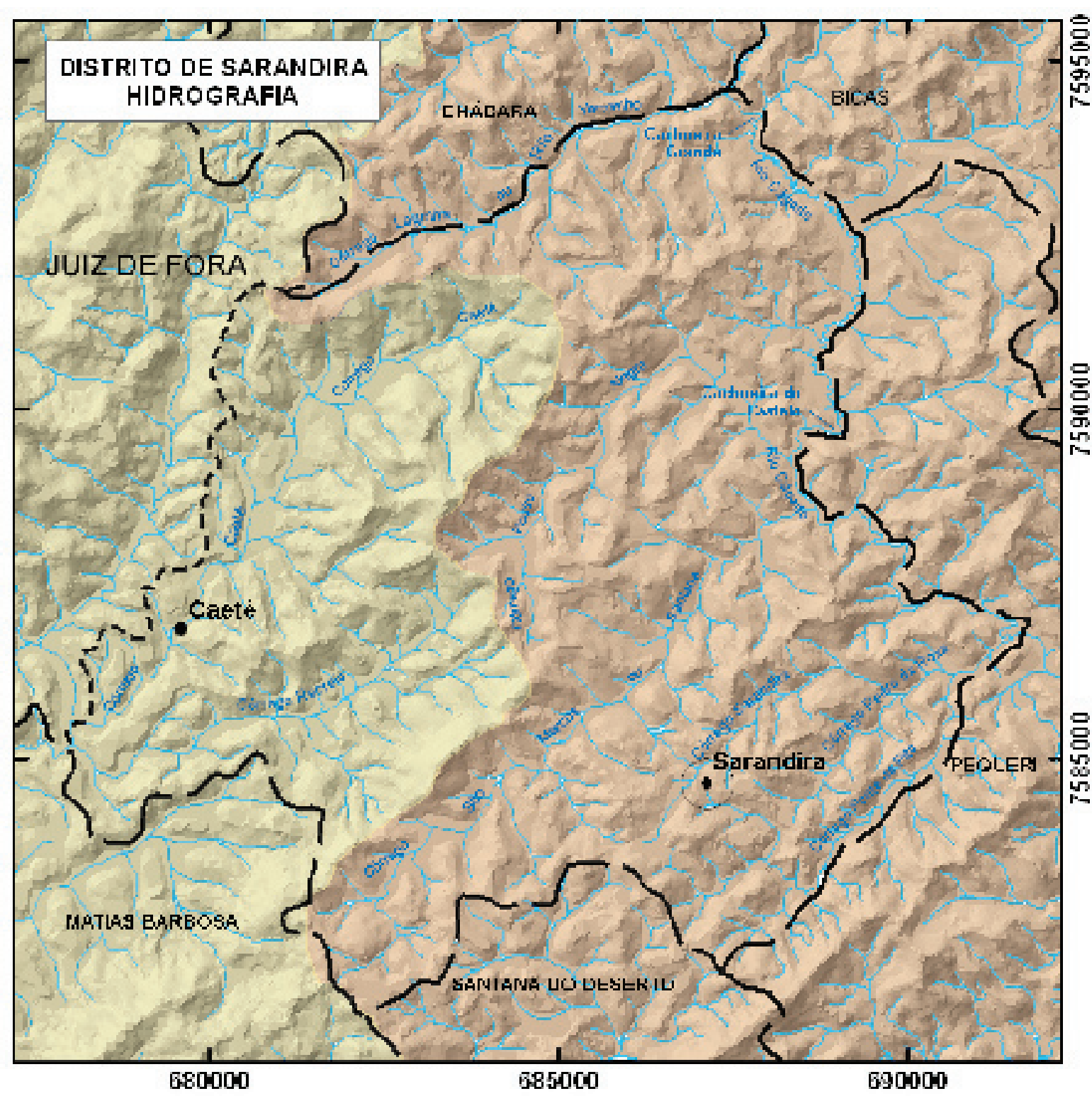


ou mais tradicionalmente por um sulco aberto no terreiro, e some por entre a vegetação do brejo.

A fim de servir aos animais, ela é por vezes barrada, formando açudes, ou é simplesmente contida em grandes manilhas, caixas d'água ou ainda mesmo em velhas banheiras esmaltadas. Nos dois núcleos urbanos, os moradores dispõem de uma precária rede de abastecimento público de água, ficando muitas vezes a seu próprio encargo sua captação.

Como ameaça a esse bem natural inestimável, a retirada da cobertura vegetal ao longo de quase dois séculos inibiu a retenção das águas de chuva, dificultando a recarga dos aquíferos ${ }^{47}$. Paralelamente, a ausência de árvores nos cimos dos morros, capazes de elevar as águas subterrâneas por capilaridade, acarretou o rebaixamento do lençol freático e, com isso, também das próprias minas. Essas acabam unindo-se às áreas brejadas, onde as nascentes são difusas, e assim têm sua pureza comprometida, isto quando não desaparecem por completo.

Nas últimas décadas, particularmente nas cristas dos morros, tem-se constatado o retorno da vegetação nativa, fator que certamente está contribuindo para a recuperação e conservação de suas nascentes. Naqueles cimos, as linhas de cumeada que dividem as "águas vertentes", são as referências comumente utilizadas para marcar os limites entre as propriedades rurais, definindo bacias hidrográficas e assegurando o acesso à água aos proprietários de terras e às suas criações.

Os diversos córregos locais recebem o nome das fazendas e vilas por onde passam ou se originam: Córrego Recreio, Pouso Alegre, Pedra Roxa, São Marcos ou Santana, Caetés, etc. Alguns pontos notáveis de sua rede hídrica são cachoeiras
47 Sobre o Paraibuna, STAICO (1976, p. 202) comenta: “(...) a média pluviométrica mais elevada coincide com a mais alta média fluviométrica, sendo janeiro o mês em que o fenômeno se verifica.Tal coincidência é explicada pela deficiência de cobertura vegetal (...). Por outro lado, a média pluviométrica mais baixa corresponde aos meses de junho e julho (...), enquanto a média fluviométrica mais baixa equivale ao mês de setembro. Essa não coincidência deve-se, também, quanto à amplitude de defasagem, à geomorfologia e cobertura vegetal atual da área da bacia: durante os meses de menor pluviosidade, a pequena quantidade de água que foi armazenada pelos solos na estação chuvosa continua alimentando o rio, vindo logo a seguir um esgotamento, quando então, depauperada a fonte alimentadora, a vazão cairá ao mínimo.'

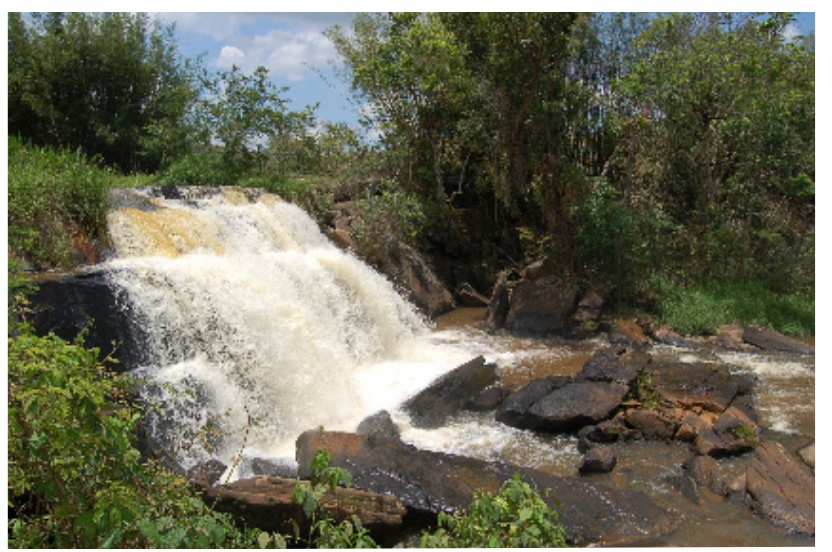

Cachoeira na Fazenda Passo da Pátria. Crédito: Autor 


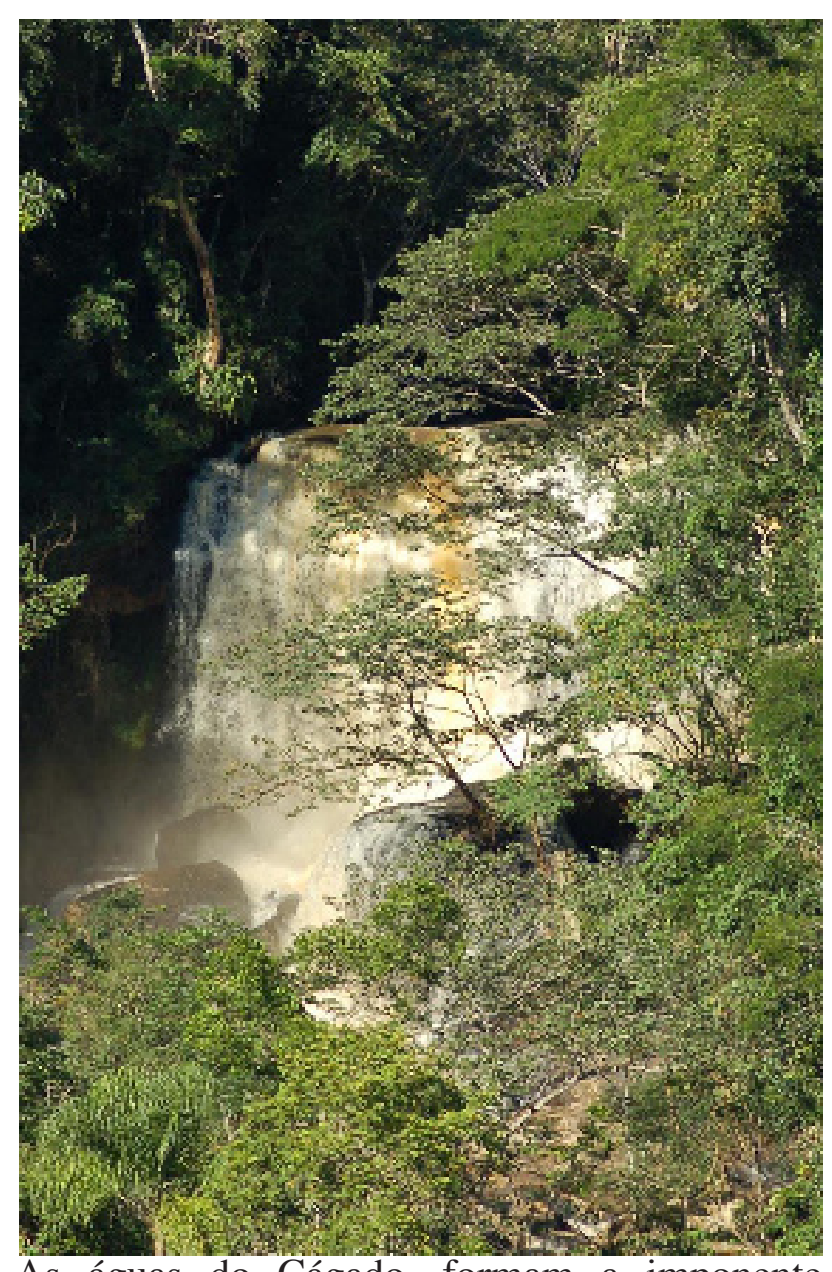

As águas do Cágado, formam a imponente Cachoeira do Castelo, localizada $2 \mathrm{Km}$ ao norte da Fazenda Santana.

Crédito: Autor como a do Castelo, da Fazenda Passo da Pátria e a Cachoeira de Sarandira, esta última explorada economicamente através da visitação pública.

A combinação de seus fartos recursos hídricos com a afamada fertilidade de suas terras, distinguem o distrito de Sarandira de outros distritos do município. E neste sentido, o conhecimento de algumas de suas características pedológicas, permite melhor entender os processos de profundas mudanças pelos quais a região sofreu, marcadamente nos últimos 150 anos. É principalmente através da qualidade de seu solo, também influenciado pelo clima e relevo, que se condicionou o desenvolvimento de sua cobertura vegetal, não apenas sua vegetação primitiva, mas dos cafezais que a ela se seguiram e posteriormente de seus campos de pastagem.

Em todo o Município de Juiz de Fora, segundo STAICO (1975, p. 181), o subsolo é formado por rochas muito antigas, gnaisses e granitos encobertos por uma espessa camada de sedimentos oriundos da decomposição das rochas originais. Em alguns locais, estas teriam sido soerguidas por movimentos tectônicos, já em outros, desnudadas pela ação erosiva.

Em Sarandira, especificamente, é curioso o fato de que algumas fazendas tenham sido batizadas com nomes como Pedra Roxa, em alusão às ametistas fracas ali encontradas à época, ou ainda Pedra Branca e Sítio Cristais, devido aos minerais que até hoje afloram à superfície destas propriedades. Embora no passado presumia-se haver metais preciosos nos arredores da vila de Sarandira, não há referências ou indícios de que tenha havido exploração aurífera na região.

Como visto, o acúmulo de grandes fortunas geradas neste distrito foi possível 
graças aos seus ricos atributos naturais, que permitiram a propagação dos extensos cafezais, tendo papel decisivo sua fértil camada superficial, enriquecida com as cinzas da velha mata, derrubada e queimada ${ }^{48}$. Mas essa cultura foi praticada de forma tão intensiva e predatória que, com cerca de 15 anos após o início do plantio, os solos já se encontravam enfraquecidos, sendo necessária a utilização cada vez maior de adubação química. Entre as fileiras de pés de café chegava-se a dinamitar a terra objetivando seu revolvimento. $\mathrm{O}$ esgotamento dos solos na região de Juiz de Fora, já no início do século XX era opontado por ESTEVES (1915, p. 115):

Grandes e florescentes cafezaes que cobriam extensas regiões estão hoje substituídos por sapezaes, pastos ou áridas capoeiras com intermináveis e destruidores formigueiros, contrastando assim a pobreza impressionante de hoje com a riqueza e o encanto que as culturas cuidadosas de outrora despertavam.

Hoje, os sinais de uma terra "cansada" são evidenciados em muitas áreas pela presença abundante de espécies como o rabo-de-burro e o sapé, colonizadoras de solos "ruins", conforme a sabedoria popular. Ainda entre os sitiantes de Sarandira, é curioso notar a distinção e o valor que atribuem a cada lugar em função de sua fertilidade. Conhecimento esse que não se pauta apenas em suas experiências anteriores de plantio, bastando um olhar superficial pelas espécies autóctones ou ruderais que ali se desenvolvem para assim atestar ou não sua qualidade. Cada pequeno pedaço de chão, para espanto dos neófitos, parece conter características muito diversas que só se revelam a olhos bem acostumados.
48 Apesar disso, quando comparadas suas terras com as de outras regiões produtoras de café, como por exemplo do sul de Minas, aquelas levam desvantagem por serem mais ácidas GOLFARI (1975) chega mesmo a apontar as características originais do solo local como um dos fatores responsáveis pelo fim daquele ciclo na Mata Mineira. 


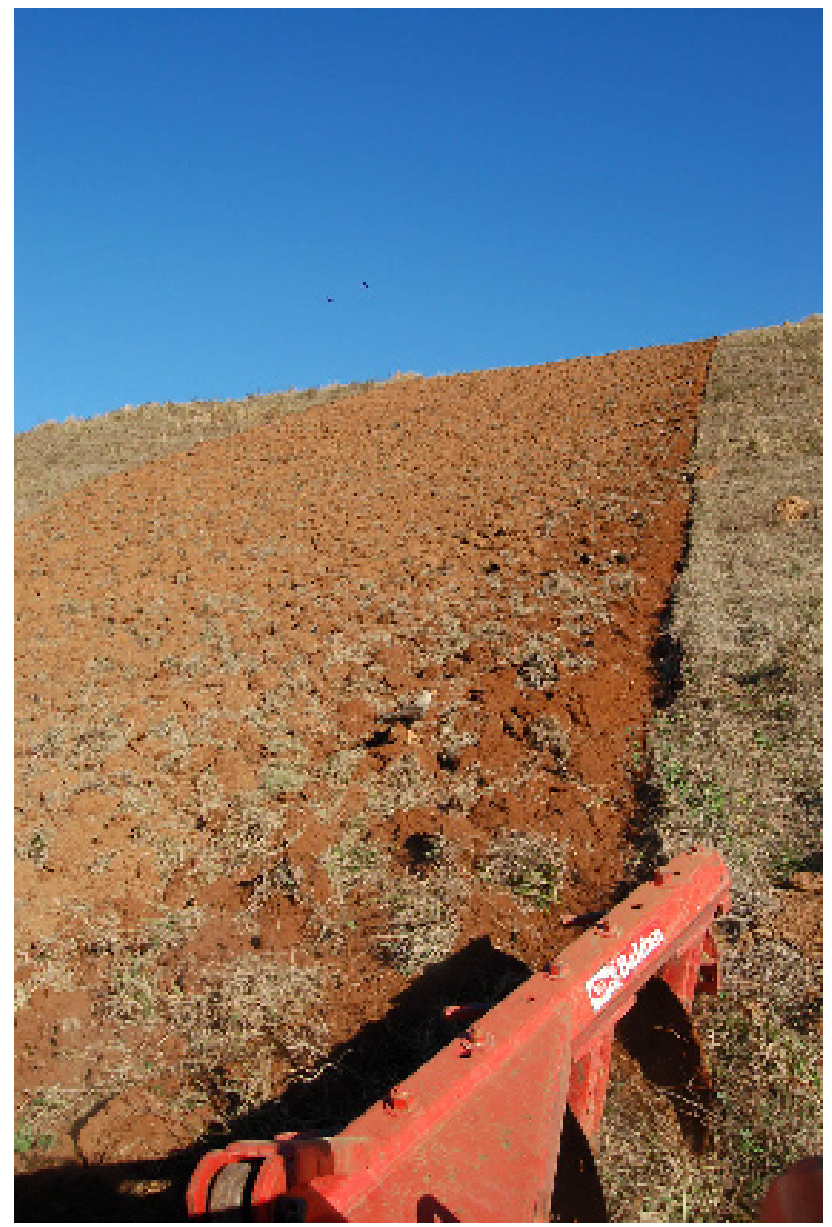

Pouco antes da entrada das "águas", o tratorista prepara a terra em uma vertente muito inclinada, para a posterior semeadura da braquiária.

Crédito: Autor
Entre aqueles sitiantes há o consenso de que onde crescem espontaneamente arbustos e árvores como assa-peixe, camará-de-bilro e grão-de-galo, a fertilidade é alta. Cupinzeiros só proliferariam nas terras mais pobres. Estes últimos são combatidos porque consomem as raízes de uma grande variedade de plantas e tendem a se multiplicar rapidamente, reduzindo a área de pastagem.

Cientificamente, a pedologia classifica a região como constituída por Latossolos Vermelho-Amarelos, caracterizados por serem muito profundos e drenados, também muito porosos e ácidos, com grandes porcentagens de alumínio.

Genericamente, as áreas preferidas para o plantio de culturas variadas são os piemontes, ou "pés dos morros", por estarem longe da umidade das várzeas, concentrarem muita matéria orgânica que se desprende das encostas e por terem melhor topografia, se comparados às vertentes escarpadas. Os principais gêneros alimentícios cultivados são: milho, feijão e mandioca. E apenas para as criações: pastagem, capineira, cana e milho.

No preparo do solo para o plantio, quando se procede a aração da terra, seu revolver às vezes revela restos de habitações antigas, como vidros, tijolos e telhas de barro, além de lajedos de pedra usados nas fundações das casas. Houve também quem disse ter encontrado artefatos indígenas, como pedras de machados primitivos. Isto evidencia os muitos anos de lida com a terra, bem como a presença de seus moradores originais, anterior à chegada dos colonizadores europeus.

Atualmente, na microrregião do município, as áreas de pastagens totalizam expressivos 78\% de seu território (Juiz de Fora - Prefeitura Municipal, 2004, p. 218). Estas certamente poderiam dispor de menor extensão caso fossem melhor 
manejadas. A inobservância de medidas voltadas à conservação do solo tem afetado a qualidade deste que é considerado um dos mais valiosos recursos naturais do município, diretamente ligado ao valor da terra. 


\subsubsection{Flora e Fauna}

49 Para AB’SABER (2003), as porções sul e sudeste de Minas apresentavam uma distribuição tão contínua de florestas sobre seus mares de morros, que foi por isso chamada de Zona da Mata, estendendo-se desde a porção ocidental das serras fluminenses até Santos Dumont, Juiz de Fora e Manhuaçu. Segundo VALVERDE (1958), a formação vegetal que designou o nome da Mata Mineira era formadora de um contínuo com a floresta do médio Paraíba, ao sul, e do vale do rio Doce, ao norte, sendo a oeste limitada pelos campos naturais do centro e do sul do estado.

50 VELOSO et al. (1991) considera a Zona da Mata pertencente à Floresta Estacional Semidecidual, devendo ainda ser classificada como Submontana (abaixo de $500 \mathrm{~m}$ de altitude) ou Montana (acima dos 500 m). Essa variação, conforme VALVERDE (1958), decorre da amplitude altitudinal que é responsável por diferentes condições climáticas. Em classificação mais recente, OLIVEIRA-FILHO et al. (1994), propõe alteração sobre a proposta de VELOSO et al. (1991) no limite que separa as formações Montana e Submontana, de 500 para $750 \mathrm{~m}$, entre as latitudes de $16^{\circ}$ e $24^{\circ}$ sul (faixa latitudinal que também compreende o distrito de Sarandira, com $21^{\circ} 50^{\prime}$ de latitude sul, e altitudes que variam entre $600 \mathrm{~m}$ e $900 \mathrm{~m}$ acima do nível do mar). Conforme SATO (1995, apud BARROS, 2006) o município de Juiz de Fora encontra-se nos limites da Floresta Estacional Semidecidual Montana.
O distrito de Sarandira pertence a uma porção do território mineiro, delimitada pela bacia do rio Paraíba do Sul, conhecida como Zona da Mata. Este nome sugere a pujança da cobertura vegetal primitiva na qual, favorecida pelo clima quente e úmido, e por solos férteis e profundos, floresciam espécies com características semelhantes àquelas da Mata Atlântica. Conseqüentemente, alguns autores consideram que no trecho correspondente à Mata Mineira, aquela faixa de floresta litorânea adentra pelo continente, a exemplo de RIZZINI (1963), para quem a região em questão integra a unidade fitogeográfica de Floresta Atlântica ${ }^{49}$.

Os remanescentes florestais encontrados no distrito de Sarandira são ainda mais precisamente classificados como pertencentes à Floresta Estacional Semidecidual ${ }^{50}$, que se desenvolvia por todo o sudoeste de Minas sobre vastas áreas férteis, intercaladas por campos naturais, que ocupavam os terraços aluvionares. A mais distinta de suas características é a perda parcial de suas folhas, mecanismo de sobrevivência de algumas espécies para suportar os meses de seca e de baixas temperaturas que caracterizam o inverno. Essa particularidade, segundo VELOSO \& GÓES (1982), é condicionada pelo clima com duas estações bem definidas, resultando a estacionalidade foliar de cerca de $20 \%$ a $50 \%$ dos elementos arbóreos.

Essa estrutura original e resiliente, atravessada por milhares de anos de apropriação indígena, foi sucumbir apenas nos últimos séculos, com os impactos avassaladores e ininterruptos deflagrados com chegada dos roceiros 
que ali se instalaram a partir do setecentos e, mais notadamente, por volta da segunda metade do oitocentos quando a cultura do café já tomava conta da região. Período no qual grandes e médias propriedades rurais baseadas na mão-de-obra escrava se multiplicaram, e as florestas remanescentes, que ainda resistiam à agropecuária de baixa produtividade até então praticada, foram todas queimadas.

Árvores consideradas nobres, que se prestavam bem à construção civil ou movelaria eram derrubadas e lavradas, conduzidas por juntas-de-boi até os engenhos, onde inicialmente transformavam-se em pranchões e peças. As demais eram simplesmente descartadas. Procedia-se o corte e em seguida o fogo era usado para "limpar" o terreno, expressão que ecoa até hoje, quando os sitiantes se referem a uma capoeira como a parte "suja" do pasto. O cafeeiro, que em seu continente de origem povoava espontaneamente os sub-bosques, crescendo à sombra de árvores maiores, tornava-se aqui uma cultura homogênea, precariamente revestindo seus mares de morros. Não apenas a extensão deste processo foi notável, mas sua velocidade.

Aos cafezais sucederam-se as pastagens, e estas, menos exigentes, adaptaramse bem ao solo da região, empobrecido após décadas de agricultura intensiva. Das diversas gramíneas introduzidas para o forrageamento do gado, a maioria delas oriundas das planícies africanas, destacam-se o capim-gordura e, nas últimas décadas, as variedades de brachiária ${ }^{51}$. Estas últimas preferidas por serem tidas como mais palatáveis aos animais, de grande produtividade, fácil multiplicação, sendo ainda pouco exigente em termos de umidade e fertilidade do solo. Por lá, há quem diga que "o mundo vai acabar em brachiária".

Nos morros, é comum a manutenção de uma ou outra árvore isolada para dar
51 Ainda, em escala bem menor, capim jaraguá, capim-colonião, estrela, napier, elefante, entre outros. Segundo DEAN (1997, p. 130): “Em algum momento do século XVIII capins africanos apareceram nas invernadas e palhadas reservadas para forragem de cavalos, próximo à cidade do Rio de Janeiro. Podem ter sido introduzidas na região da Mata Atlântica a partir das camas de palha dos navios de escravos. (...) Essas transferências acidentais prosseguiram, de sorte que, ao final do século XX, mais de quarenta espécies de capim africano foram encontradas em pastos brasileiros."

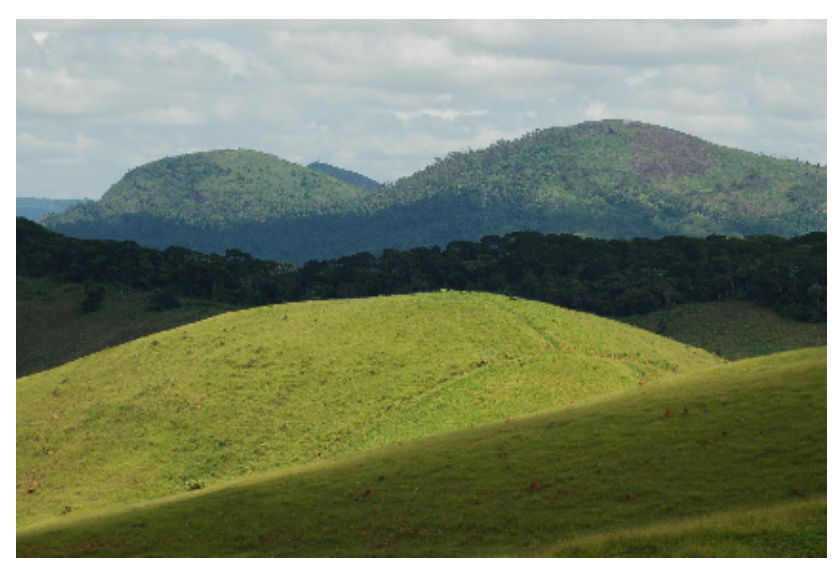

Intercalados, pastos e topos de morro florestados. Crédito: Autor 
52 VALVERDE (1958) informa que na Zona da Mata a invasão de espécies do cerrado em áreas antes florestadas começou no início de seu desmatamento, fim do século XVIII e princípio do XIX.

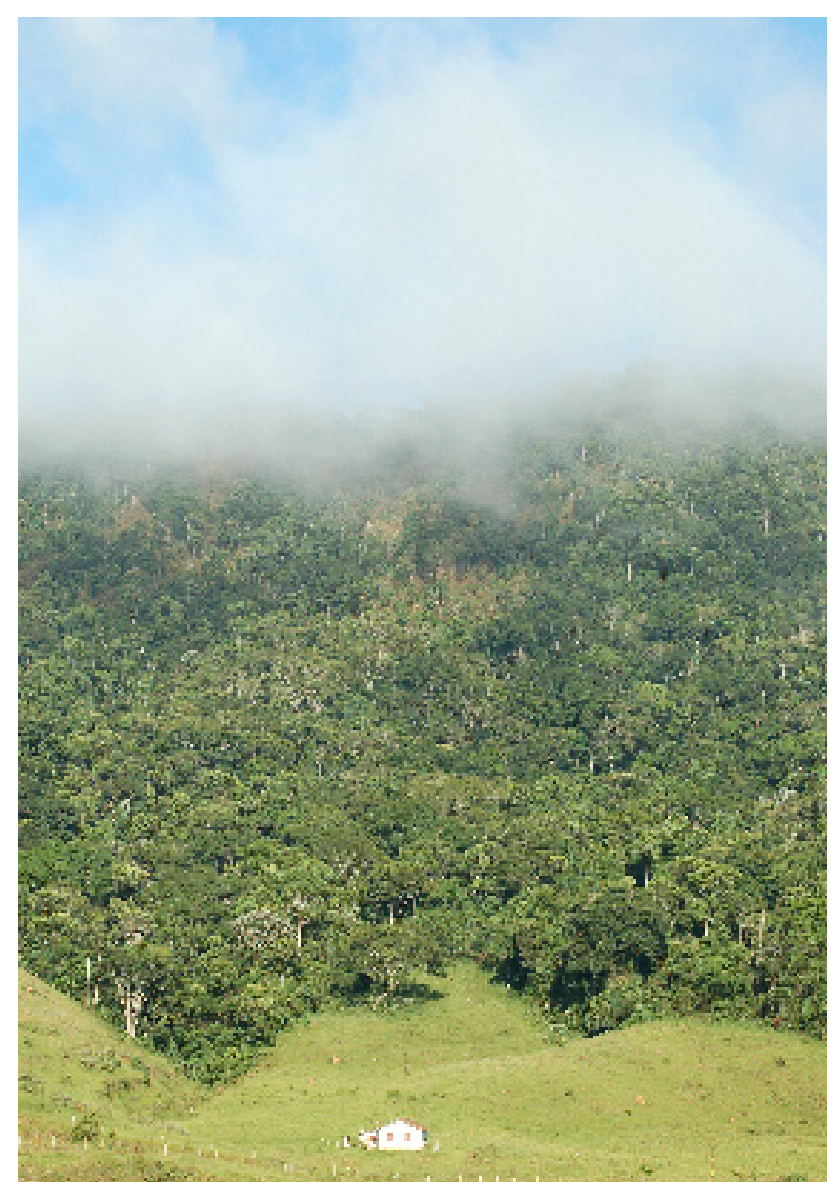

Casa de colono com mata densa ao fundo, que cresce vigorosamente sobre antigo cafezal. Crédito: Autor sombra ao rebanho, geralmente garapas, angicos, ipês e jacarés, que normalmente colonizam áreas degradadas, germinando e desenvolvendo-se com facilidade. Mas não são raros os que optam por deixar o pasto completamente "limpo" sem qualquer tipo de vegetação além das gramíneas.

Daí resulta sua paisagem predominantemente composta por pastagens, matriz sobre a qual se sobrepõem de forma pulverizada algumas culturas e manchas de florestas nativas em variados estágios sucessionais, basicamente capoeiras e capoeirões, raramente "matas velhas", como costuma-se dizer, e uns magros talhões dedicados ao eucalipto. Com isso, uma das conseqüências da supressão florestal foi a proliferação de espécies vegetais e animais típicas dos campos, não do interior da mata densa ${ }^{52}$.

Algumas das árvores mais características de Sarandira, com a nomenclatura usual empregada localmente, são: açoita-cavalos, amendoins-do-campo, angicos-brancos, angicos-vermelhos, araçás, articuns, bicos-de-pato, cabeludinhas, cabiuninhas, cafezinhos-do-mato, cajuzinhos, camarás-debilro, camboatás, canafístulas, capoeiranas, capoeiras-brancas, carvãozinhos, castanhas-de-macaco, cedros, cinco-folhas, embaúbas, fedegosos, figueirasbrancas, figueiras-mata-pau, folhas-santas, garapas, goiabeiras, grãos-degalo, gumerins, ingazeiros, ipês-amarelos, ipês-tabaco, jacarandás, jacarés, leiteiras, limoeiros-bravos, louros, maminhas-de-porca, mulungus, mutambos, negas-minas, paineiras, papagaios, paus-d'alho, patas-de-vaca, perobas-rosas, perobas-do-campo, pimenteiras, pitangueiras, quaresmões, quaresmeiras, sessenta-e-dois, tajuvas e vaquinhas. Entre os arbustos mais abundantes estão: assa-peixes, camarás, carrapichos, lobeiras, quaresminhas e vassourões. Entre as palmáceas: brejaúvas, jerivás e palmitos. 


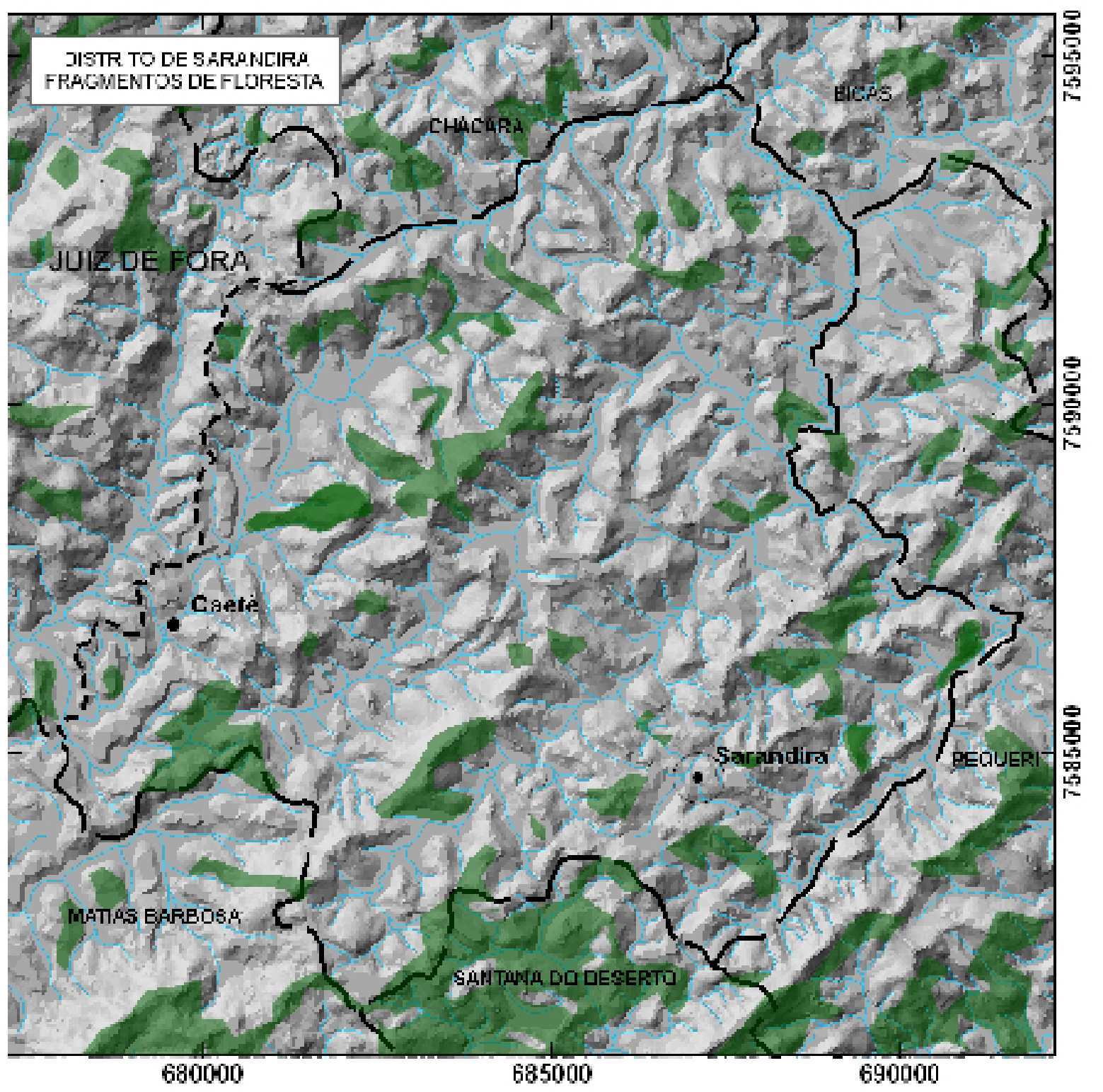

\section{LEGENDA}

Fragmentcs ce Florestas

- Vlla (sede de distrito)

- Pcvoado

L Limite de Municipio

-.. Limite de cistrito

C Cirsos d'água

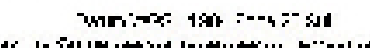

- $\operatorname{con} m:$.
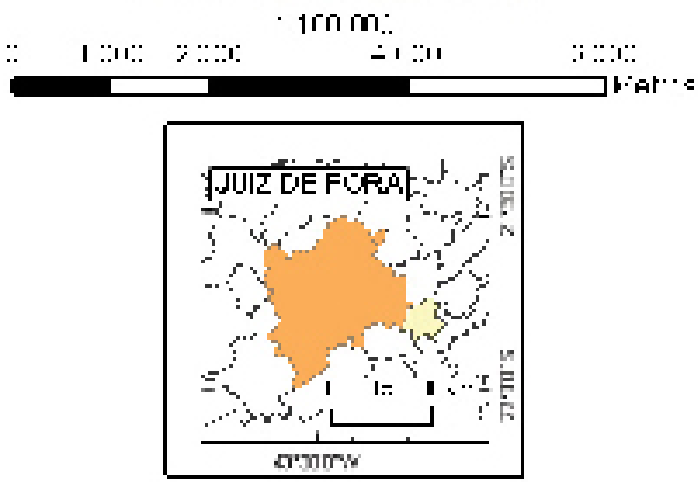

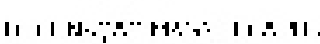

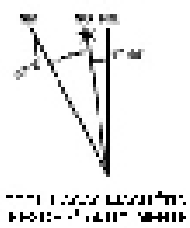

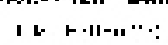

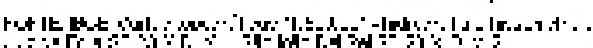

and

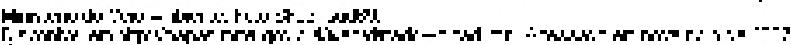

thentyon

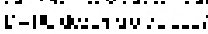




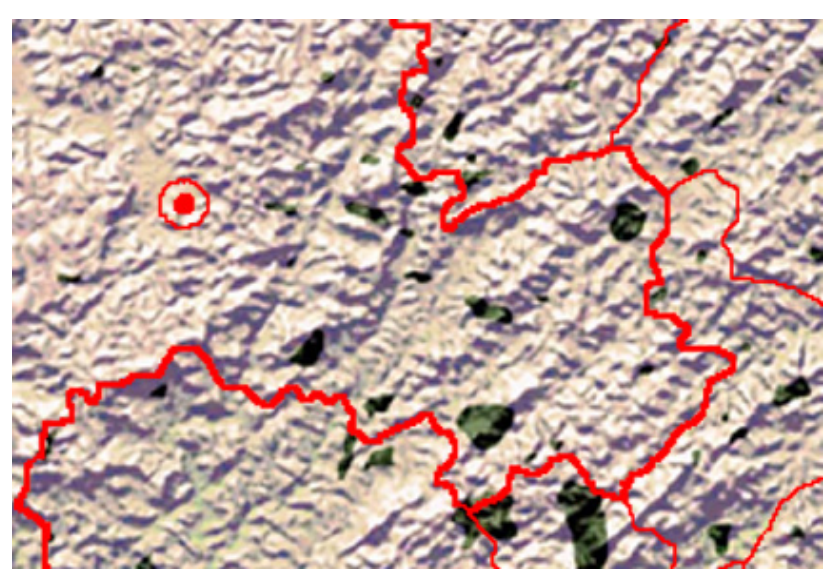

Distribuição das matas no distrito de Sarandira e seu entorno, em 1936 (utilizando a divisão político-administrativa atual).

Crédito: Autor. Fontes: Mapa da Comissão Geográphica e Geológica de Minas Geraes (1936), Folha Palmira

53 Segundo ESTEVES (1915, p. 477) no escoamento de café e demais produtos do distrito de Sarandira para o Rio de Janeiro, um pernoite forçado acontecia em "Vargem", onde abundavam os caetés. Assim, diziam localmente que, pernoitando nos "caethés", forrassem os carros de bois com muitas folhas, evitando as chuvas no café. A toponímia Vargem se perdeu com o tempo, mas presume-se, pela leitura de Albino Esteves, ser o primeiro nome da região de Caeté. Paralelamente, aquela palavra originase do tupi caá-etê, mata verdadeira ou densa, que se alinha aos relatos históricos do desbravamento de "grande mata virgem" (ESTEVES, 1915, p. 476) nas terras onde hoje se localiza o arraial.
São essas as espécies mais evidentes que crescem nas capoeiras distribuídas pela zona rural, ocupando quase exclusivamente os topos de morros e encostas muito íngremes, principalmente as vertentes voltadas para o sul, menos ensolarado, onde a maioria das culturas desenvolve-se com maior dificuldade sendo, por isso, não raro abandonadas. Por vezes são conservadas junto às nascentes, em especial aquelas de onde se capta água para a propriedade, mas apenas em raríssimos locais são mantidas ao longo da rede de drenagem. Assim, praticamente inexistem matas higrófilas, e a maior parte das áreas brejadas tornaram-se pastos, onde os vegetais destinados à alimentação animal, vez ou outra, coexistem com espécies nativas mais rústicas, como ananazes, avencas, canas-de-macaco, canudinhos-do-brejo, capins-de-cabrito, embiris, maricás, taboas, lírios-do-brejo e as temidas ervas, fatais quando ingeridas pelo gado. Vulgarmente distribuídas e adaptadas a ambientes variados: piteiras, samambaias diversas e taquaras; epífitas como bromélias comuns, cravos-do-mato, barbasde-velho e orquídeas; lianas e trepadeiras como cipós-cravo, cordas-de-viola, olhos-de-boi, maracujás-do-mato, timbós e unhas-de-gato; ervas e gramíneas como alecrins, alfavacões, carquejas, canudos-de-pito, capins-navalha, cravosde-defunto, ervas-cidreiras, juás-bravos, macelas, malícias, picões, quebrapedras, tiriricas, rabos-de-burro, sapés e gramas-de-pasto. Não tão vulgares quanto supostamente foram no passado há ainda os caetés, termo que abrange entre outros as bananeiras-do-mato e helicônias, relacionados, de acordo com ESTEVES (1915), ao topônimo Caeté ${ }^{53}$.

Embora seja relativamente pequeno o total de áreas florestadas neste distrito, ainda mais quando comparadas àquelas presentes em Santana do Deserto - com quem faz divisa ao sul - vale lembrar que à época da cafeicultura até mesmo as escarpas mais inclinadas e topos de morro foram ocupados por aquelas 
lavouras. Assim, a existência dessas matas secundárias, de certa forma, devese ao estabelecimento da pecuária. Por conta do relevo acidentado há locais de acesso muito difícil para o gado. Ademais, os atuais proprietários não possuem tantos recursos quanto os antigos barões da cafeicultura, como a farta mão-deobra que lhes permitiu a superutilização do terreno. Com isso, a formação de pastagem em toda a propriedade tem um custo elevado demais para muitos, diante das baixas perspectivas de retorno financeiro com a criação animal. Ainda neste sentido, como já se viu, a obediência ao Código Florestal, no que tange à manutenção de Reservas Legais e APPs, parece ter pouca influência, dada a sua impopularidade e quase total descumprimento. Já a consciência da conservação das nascentes pela presença das matas é totalmente difundida e, ainda que insuficientemente praticada, certamente contribui para sua permanência.

Em 1936 as matas do distrito de Sarandira eram poucas, concentradas, e cobriam $8 \%$ de seu território. Hoje, distribuídas de forma mais pulverizada, totalizam $15 \%$ de sua área.

Embora existam em grande número, a falta de conectividade entre os remanescentes limita sua importância na conservação da biodiversidade. Também suas dimensões reduzidas e seu formato irregular e muitas vezes longilíneo, por muitas vezes ocuparem as linhas de cumeada entre vertentes, acabam potencializando os chamados efeitos de borda que incidem sobre eles, aumentando as áreas que sofrem maior perturbação externa ${ }^{54}$. Tais fatores levam a drásticas alterações estruturais e microclimáticas das matas, ameaçando a manutenção de sua flora e fauna, e contribuindo para extinções locais.

Assim, em Sarandira, ao longo dos últimos dois séculos a supressão da cobertura vegetal causou impactos irreversíveis à rica fauna então típica do bioma da Mata
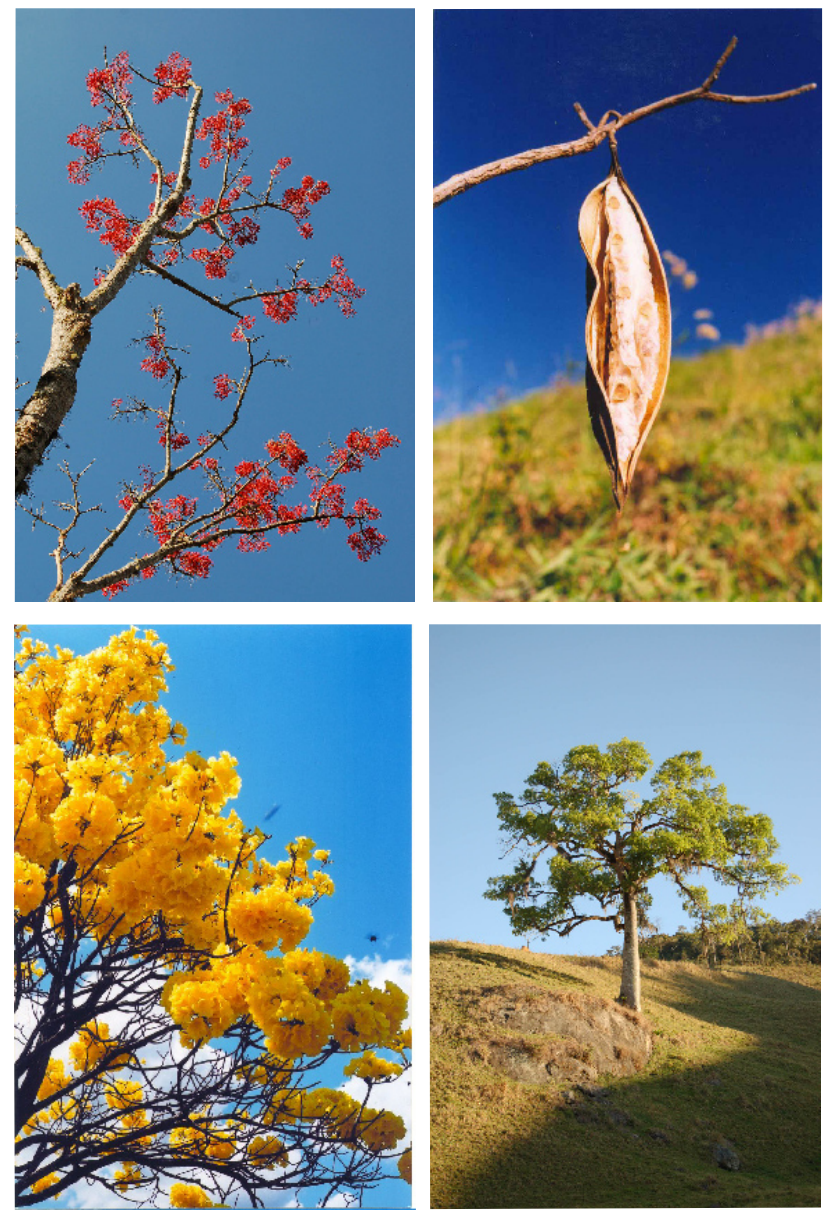

Detalhes da flora local. No alto, em meio às pastagens, mulungus. Abaixo, ipê e paineira. Crédito: Autor

${ }^{54}$ Segundo Viana (1990), os efeitos oriundos do formato dos fragmentos sobre a biodiversidade são tão marcantes quanto àqueles oriundos do seu tamanho. 
55 No caso daqueles bovinos as mortes por picada de cobra são extremamente comuns, embora sejam consideradas acidentes, já que não têm caráter predatório.
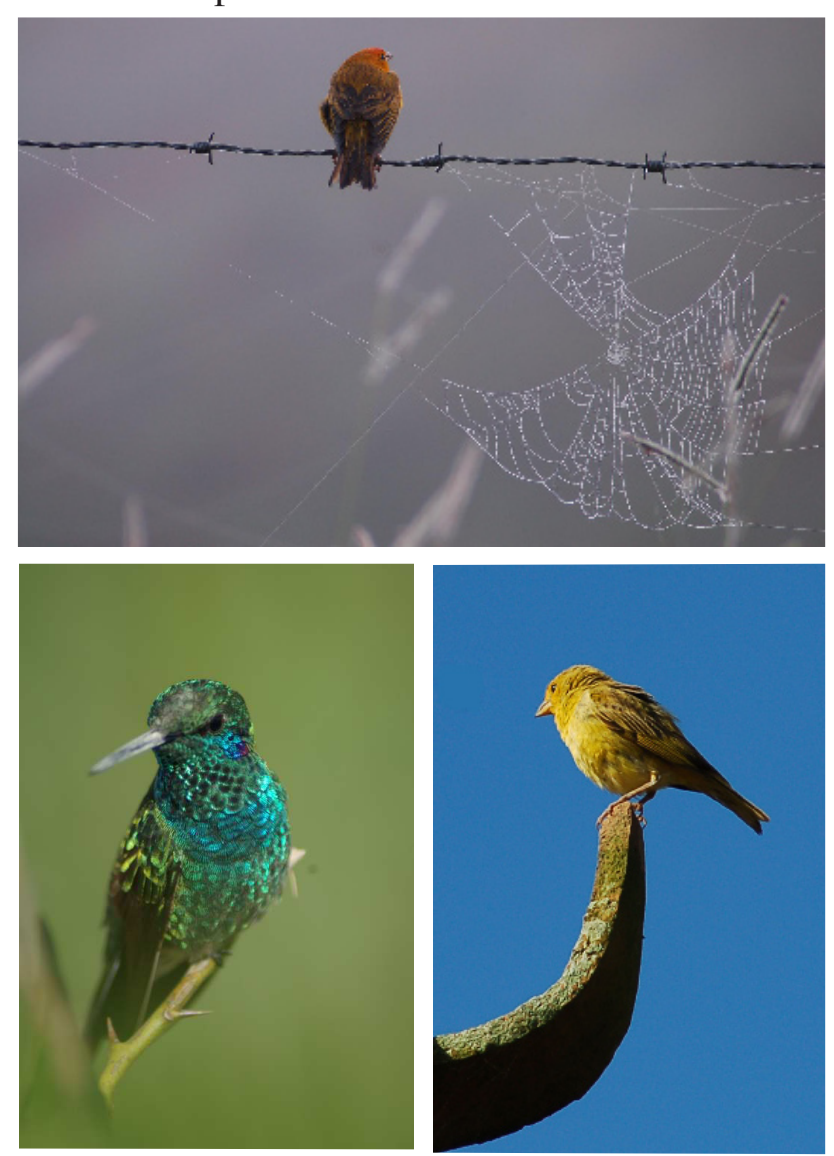

Beija-flor, e canários-da-terra. Estes últimos, muito bem adaptados à vida ao redor das casas e currais, tornaram-se onipresentes na paisagem do distrito.

Crédito: Autor
Atlântica. Suas pequenas matas secundárias não permitem abrigar os animais mais sensíveis a alterações em seu habitat, e mesmo para algumas espécies que ainda sobrevivem em seu interior, fatores como a redução do numero de seus indivíduos, somada à consangüinidade, isolamento espacial, entre outros, tendem à condená-los à extinção. Grandes predadores migraram há tempos para outras regiões embora, ainda que muito raramente, alguns sitiantes locais quando encontram suas reses feridas ou mortas atribuam o ocorrido a uma onça. Mas de certo, entre os felinos, jaguatiricas são avistadas com certa regularidade.

Se por um lado cobras, lagartos, carcarás e cachorros-do-mato rotineiramente alimentem-se das pequenas criações, outros grandes responsáveis pela morte desses animais - e em algumas raras situações até mesmo de bezerros - são os cães domésticos, tão numerosos ${ }^{55}$. Quando em grupo, podem atacar qualquer coisa, de cavalos a pessoas. Não raro acabam predando os já ameaçados animais nativos, como furões, tamanduás-mirins, macacos e quatis que, em campo aberto, deslocando-se entre um fragmento e outro, tornam-se mais vulneráveis. Essas caçadas espontâneas não são apenas motivadas pelo instinto de caça, mas também pela necessidade de complementação de suas dietas, constituídas dos restos do almoço familiar, basicamente arroz e angu. Nesta atividade os cães costumam ficar alguns dias longe de seus domínios, retornando quase sempre feridos, e não somente pela vegetação. Animais como o quati, apesar do pequeno porte, aplicam mordidas poderosas. O ouriço-caixeiro costuma deixar para trás seus agressores - ou os desavisados como bois e cavalos - cravejados de espinhos. O jaritatá, variedade de gambá, expele um líquido fétido que desnorteia os cães, fugindo incólume ante o embate. Outros preferem blefar: porcos-do-mato arrepiam os pelos de seu dorso e pescoço, dobrando seu tamanho aparente, para com isso afugentar seus predadores. Por fim, os cães ainda estão sujeitos a uma 
picada de cobra, cuja principal representante do gênero na região é a jararaca.

Na tarefa de "bater pasto", a depender do local, em um único dia de trabalho um homem pode matar até meia-dúzia delas. $\mathrm{O}$ primeiro golpe, ensinam os mais experientes, deve ser dado com as costas da foice, no meio da cobra, impedindoa de dar o bote. Só aí é desferido um segundo, e mais preciso, na cabeça. O fato é que muitas vezes, após a primeira foiçada, o trabalhador abandona aos pulos o local, tamanha a repulsa a esses bichos. Certificada a sua morte ele a pendura na cerca de arame, para evitar o susto desnecessário de topar com ela novamente, ainda que morta, esperando também com isso o reconhecimento de seu bom trabalho por parte do patrão, afinal crê estar prestando um grande serviço.

O medo que se tem desses animais é exagerado, mas não completamente injustificável. Os mais velhos contam e recontam inúmeras histórias que vão se perpetuando e adquirindo contornos cada vez mais fantásticos sobre seus encontros com esses peçonhentos e os acidentes daí decorrentes ${ }^{56}$. O procedimento comum na grande maioria desses casos é a ida ao hospital mais próximo, na cidade, embora há relatos de pessoas que não recorreram a nenhum tipo de tratamento. Houve alguns casos de óbito, mas os acidentes só foram mesmo freqüentes no passado. Roçava-se o pasto descalço, já que sapatos eram artigos de luxo, e para o tratamento de picadas apelava-se a remédios caseiros ou ainda a simpatias que por vezes não surtiam o efeito esperado.

O grande número destes répteis é uma prova clara do desequilíbrio ecológico local. A transformação de densas florestas sombreadas em campos de pastagem trouxe dois benefícios para esses predadores, a abundância de roedores e também de luz solar, responsável por sua termorregulação (SAZIMA, 1992, In MARQUES \& SAZIMA, 2004). Melhor para as seriemas ${ }^{57}$, exímias caçadoras
56 Um senhor relatou que, quando moço, foi mordido em duas ocasiões. Em uma delas, foi pegar uma panela de ferro que estava junto a um mourão de cerca, ao sol. Quando levou a mão à panela, saiu com a jararaca pendurada em seu dedo indicador, dentes cravados. A outra picada, quase fatal, aconteceu em meio a um capinzal bem denso que se debruçava sobre a trilha, tornando difícil enxergar por ande se andava. Sentiu apenas um choque violento em sua perna. Não conseguiu ver sua agressora, até porque "a vista escureceu na hora". Mas dias depois uma grande jaracuçu foi morta nas proximidades.

57 Um residente de Caeté conta que em sua infância pobre, sua mãe chegou a preparar uma seriema para alimentar a família. As grossas coxas da ave garantiram uma boa refeição. Em outra ocasião, conta o mesmo morador que, após uma caçada, recolheram um ovo deste animal e o colocaram em meio aos ovos de uma galinha, que estavam sendo chocados no terreiro. Algum tempo depois, corria em meio aos pintinhos uma enorme ave que não parava de crescer, até que em certo dia ela bateu asas e partiu, deixando inconsoláveis as crianças da casa. 
58 Há sempre quem narre fatos incríveis. Um destes refere-se a um lobo que teria atacado, há alguns anos, um homem a cavalo. De concreto, costumam ser vistos cruzando as estradas, furtivamente, embora saiba-se da existência de alguns deles menos ariscos: um costumava deitar-se junto às vacas nas madrugadas mais frias, e quando o retireiro se aproximava para trazê-las até o curral, o lobo, sempre calmamente, levantava-se e tomava outro rumo.
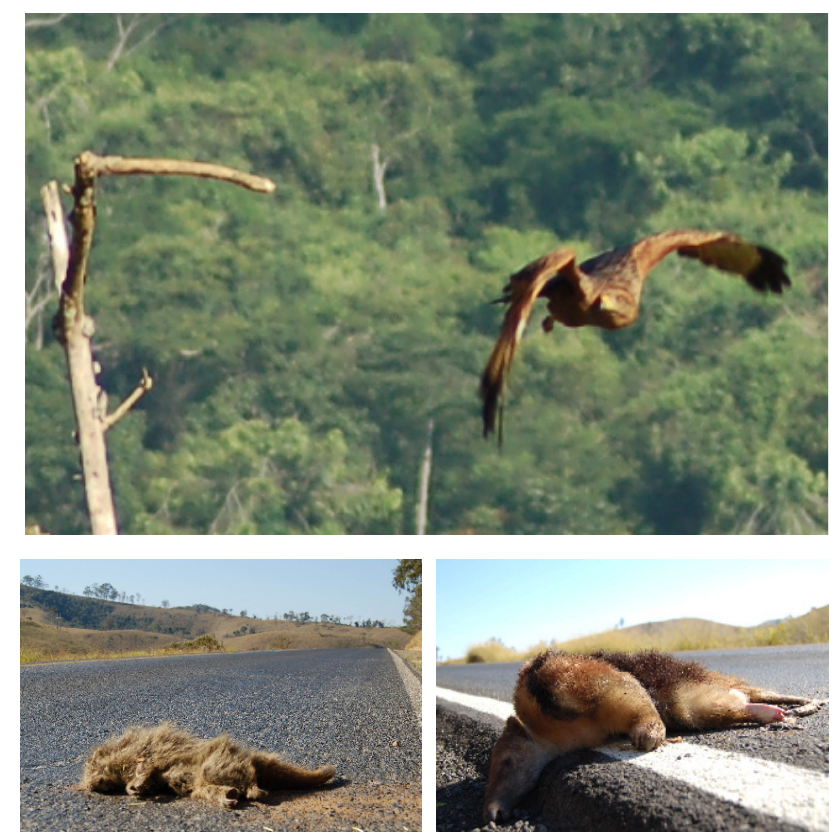

Na imagem maior, o grande gavião-asa-de-telha alça vôo do galho seco de uma embaúba. Abaixo, ouriço-caixeiro e tamanduá-mirim atropelados na extremidade norte do distrito, em seus limites com a BR-267.

Crédito: Autor de cobras. Essas grandes aves, com suas velozes pernas, passam o dia correndo os pastos, alimentando-se de répteis, ratos e insetos e emitindo, especialmente em dias chuvosos, um canto longo e estridente.

O lobo-guará, maior dos canídeos sul-americanos e o mais ilustre representante da fauna local, é outro que por ali se adaptou muito bem, tendo migrado das regiões de campos para esse ambiente transformado pela supressão da mata fechada. São avistados rotineiramente e, por isso, já não causam tanto espanto. São tidos como dóceis, mas recomenda-se certa cautela se cruzar no seu caminho uma fêmea acompanhada de filhotes ${ }^{58}$.

Os tatus são igualmente abundantes e ainda caçados, muito embora todos conheçam as penalidades impostas a essa atividade, hoje considerada criminosa. Aliás, por conta da atual legislação, quase não se encontra mais passarinho em gaiola. Assim, enormes bandos de canários-da-terra, antes considerados raros, crescem ainda mais, favorecidos principalmente pela disponibilidade de sementes dos capins introduzidos nas pastagens, base de sua alimentação.

A presença de um número elevado de indivíduos da mesma espécie e o surgimento de outras que não são comuns à região, costumam ser precipitadamente entendidos por muitos entre aqueles moradores como fator positivo, que apontaria o restabelecimento do equilíbrio ambiental local. Mas servem acima de tudo como bons indicadores do grau de perturbação de seu ecossistema. Fato este que, no entanto, não desfaz sua importância como hábitat para uma fauna surpreendentemente diversificada.

Dentre os animais selvagens que são avistados no distrito, utilizada a nomenclatura empregada localmente, estão os mamíferos: cachorros-do-mato, 
capivaras, coelhos, cuícas, furões, gambás, iraras, jaguatiricas, jaritatás, lobosguarás, lontras, macacos-barbados, mãos-peladas, micos, morcegos-de-fruta, morcegos-vampiros, ouriços-caixeiros, pacas, porcos-do-mato, preás, quatis, ratazanas, sauás, tamanduás-mirins, tatus e veados. Aves mais comuns são: almas-de-gato, andorinhas, anus-brancos, anus-pretos, beija-flores, bem-tevis, bicos-de-lacre, caburés, cambacicas, canários-da-terra, carcarás, corujasbrancas, corujas-buraqueiras, curiangos, falcões-de-coleira, garças, gaviõesasa-de-telha, gaviões-pombos, gaviões-carrapateiros, guaxos, joões-de-barro, maguaris, marias-pretas, maritacas, martins-pescadores, mutuns, pássarospretos, pássaros-pretos-do-brejo, paturis, periquitos, pica-paus, pica-paus-docampo, pintassilgos, pombas-juriti, pombas-trocal, quero-queros, tiés-sangue, rolinhas, sabiás-laranjeira, sanhaços, seriemas, siriris, tesourinhas, tico-ticos, tizius, trinca-ferros, tucanos, urubus e viuvinhas. Os peixes mais comuns nos ribeirões e açudes, e fartamente pescados, são acarás, bagres, lambaris e traíras. Entre os répteis estão os cágados, calangos, cobras-de-duas-cabeças, pererecas, rãs, rãs-pimenta, sapos-cururus, sapos-ferreiros, teiús e uma grande variedade de cobras, como boipevas, caninanas, cobras-verdes, corais, falsas-corais, jaracuçus, jararacas, jararacas-dormideiras e joões-do-campo.

Suplantando aquelas últimas, ocupando fortemente o imaginário popular local como criaturas das mais detestáveis, e por esse motivo emergindo das normalmente esquecidas listas de artrópodes, estão: moscas, cupins, carrapatos e saúvas. Estes antigos e persistentes inimigos, pelos danos que causam e por sua invulnerabilidade, provavelmente contribuíram para a formação do caráter resignado do homem do campo.
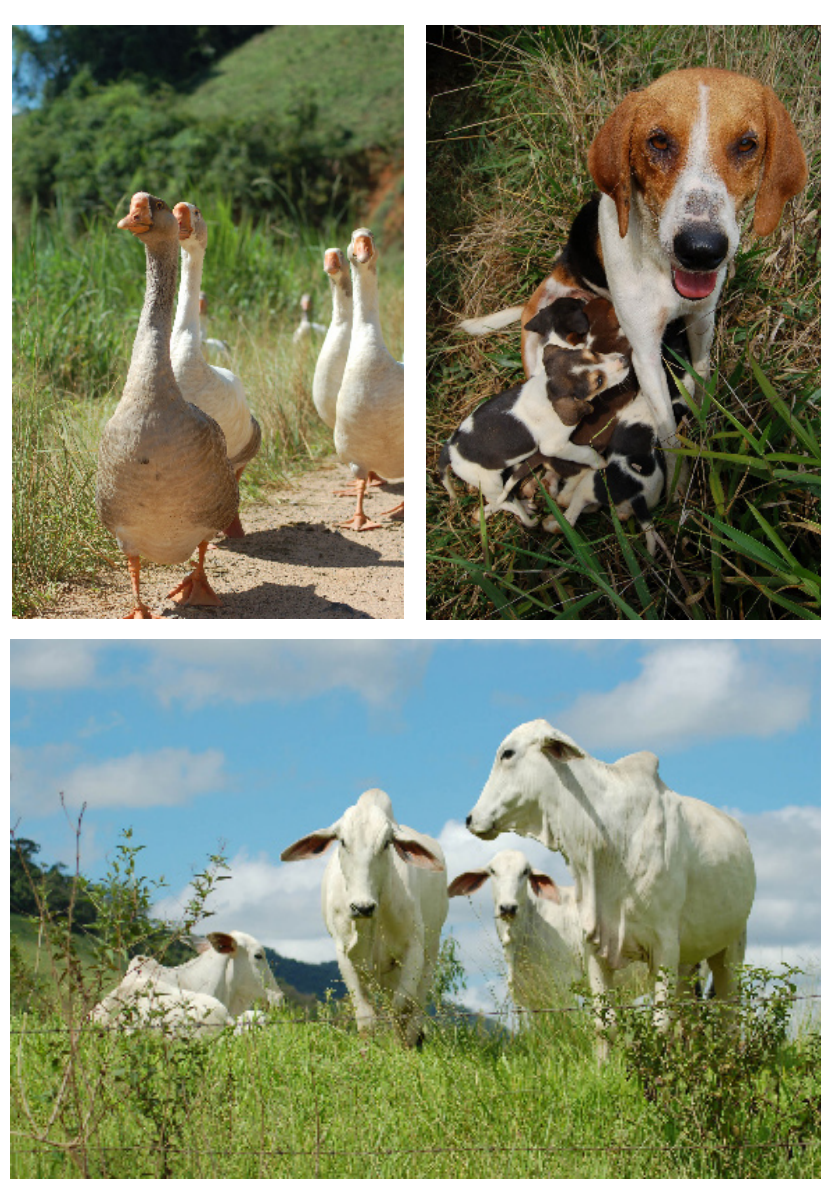

Acima, gansos e cães, que ao lado de galinhas, patos, porcos e gatos, são os representantes mais típicos da fauna exótica que habita os terreiros. Abaixo, o gado de corte que pontua os morros daquela região.

Crédito: Autor 


\subsection{Patrimônio arquitetônico}

Destacam-se na paisagem de Sarandira amostras relevantes de seu passado, ícones arquitetônicos do extinto ciclo econômico cafeeiro que, por conta de seu valor histórico, constituem um importante patrimônio cultural.

Atravessando o tempo, essas edificações, além de ilustrarem a apropriação espacial da região, são também expressões concretas de técnicas construtivas, opções estéticas, programas e partidos de um período da arquitetura nacional cujos expoentes são hoje cada vez mais raros.

Pretende-se aqui apresentar os mais notáveis remanescentes desta arquitetura, fartamente presentes em suas fazendas, e significativamente mais rarefeitos em seus dois povoados, destacando o modo como sua inserção no terreno e a disposição de seus equipamentos têm papel importante na conformação de sua paisagem. Além das frondosas casas senhoriais, que ocupam a maior parte deste levantamento, estão casas de colonos, tulhas, terreiros e outras estruturas que compunham aquele complexo produtivo, além de residências e igrejas em Caeté e Sarandira que representam um rico patrimônio material.

Infelizmente, salvo raras exceções, estes vêm sendo precariamente mantidos, quando não abandonados por completo ou ainda destruídos. Em seu lugar, mais notadamente no povoado de Caeté, a urbanização avança, requalificando sua paisagem. 


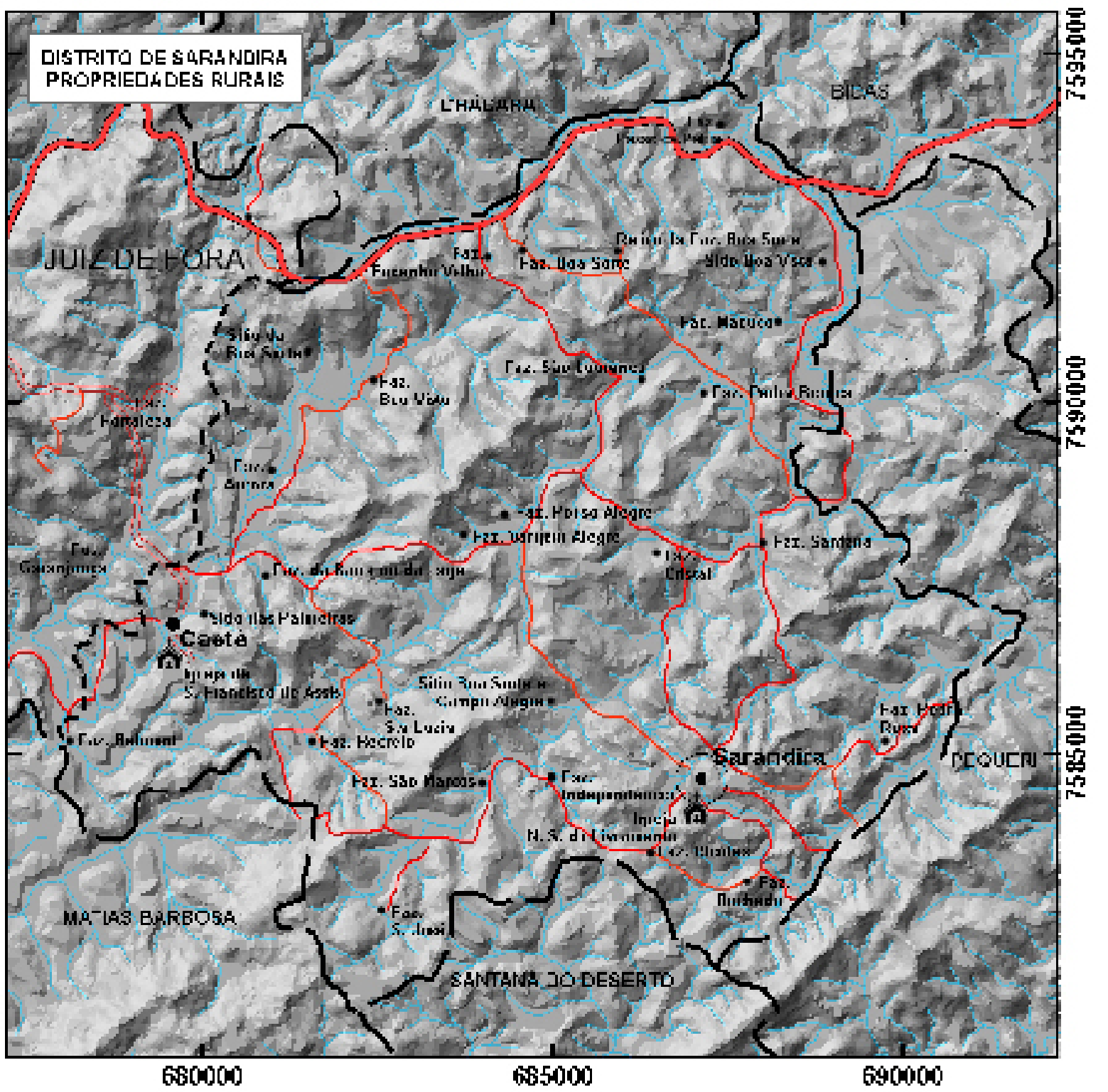

LEGヒNLA

- Vila (sede de distrito)

- Povoado

- Trapriedaces Rurais

$\longrightarrow$ Limite de Municipio

RODCVIAS

bonomen Faderal

> Pavimentada

- - Limite de distrito

- Cursos d'água

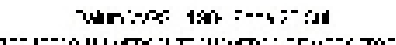

1. $0: 0: C$
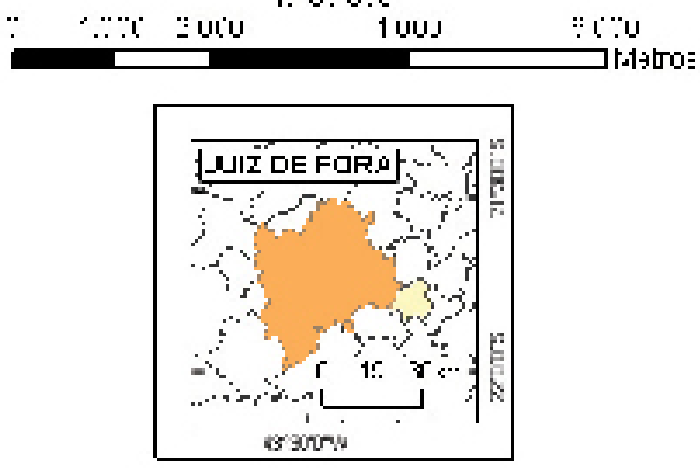

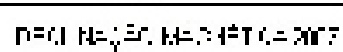

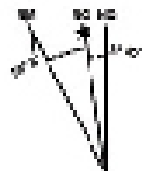

":-1:

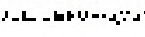

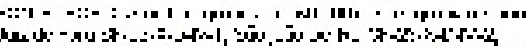

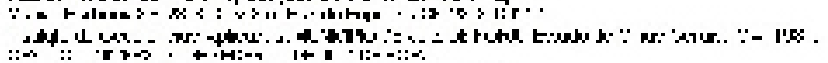
- 


\subsubsection{Fazendas}

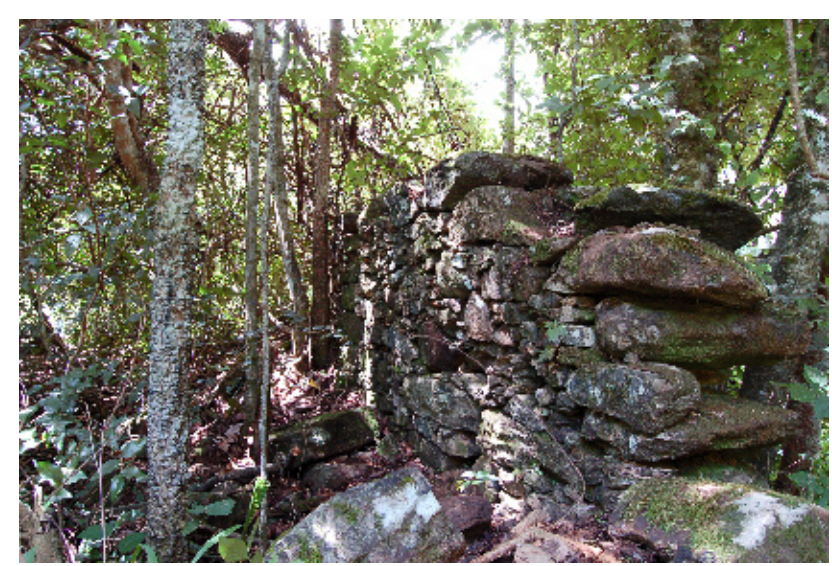

Tomado pela vegetação, na Serra da Mangueira, um muro em ruínas é o último resquício das construções da Fazenda Santa Luzia. Crédito: Autor

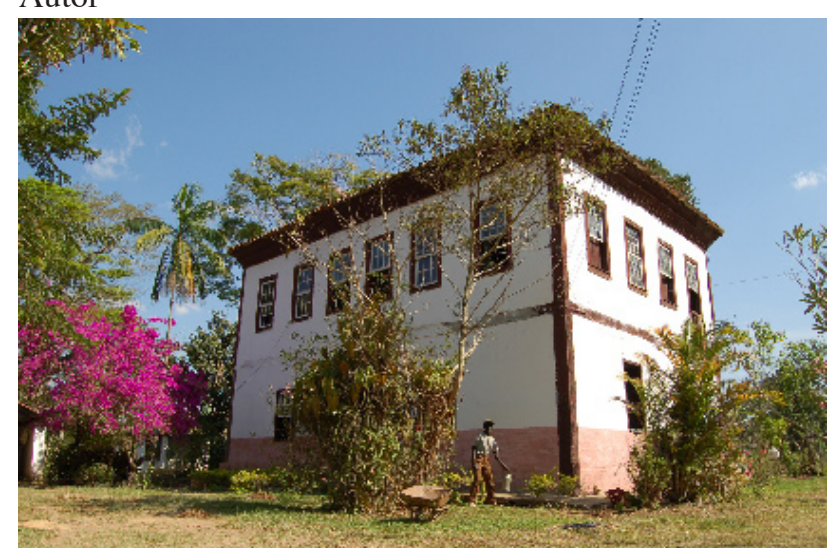

Fazenda Garanjanga, situada à entrada de Caeté. Crédito: Autor
O conjunto arquitetônico e histórico de cada uma das fazendas aqui descritas, necessário ressaltar, passou por muitas transformações ou, simplesmente, se perdeu. Cada uma daquelas fazendas constituía uma empresa - bem equipada de produção intensiva, na qual a casa-senhorial, que figura hoje como o principal resquício daquela época, era uma entre várias outras instalações do complexo. Como permaneceram em uso, estas casas foram de alguma forma mantidas.

Entre as primeiras propriedades rurais constituídas no atual distrito de Sarandira estão as Fazendas Santa Luzia e Córrego da Laje, possivelmente anteriores à chegada da onda cafeeira no distrito. Quanto à Santa Luzia, originalmente uma sesmaria, quase nada se sabe. Suas terras foram há muito tempo divididas em várias propriedades menores. Mas a toponímia Santa Luzia permaneceu, conferindo certa unidade à sua atual vizinhança, situada na bacia do Córrego Recreio. Os únicos indícios de sua existência, agora engolidos pela vegetação nativa, são as ruínas de um muro de pedras e algumas gigantescas árvores frutíferas que emprestaram nome ao local exato de sua construção: Serra da Mangueira. A Fazenda Córrego da Laje, como visto no capítulo anterior, foi o primeiro importante vetor de desbravamento das terras de Caeté. Dela, hoje resta apenas sua tulha.

\section{Fazenda Garanjanga}

Situa-se junto ao arraial de Caeté, e embora pertença à zona rural do distrito 
sede de Juiz de Fora, e não ao distrito de Sarandira, liga-se fortemente à este por sua proximidade com o arraial.

Não se sabe ao certo o período em que foi erguida, mas sua casa-grande - um imponente sobrado - parece ser característica de uma época ligeiramente anterior à da construção da maioria das demais sedes de fazenda do entorno, podendo não ter surgido em meio à fase mais rentável da cafeicultura. A eles comparado, o sobrado é menos rebuscado e tem dimensões menores, especialmente na largura, mas contando com a altura próxima à daqueles. O resultado é uma volumetria compacta, que transparece solidez. No primeiro pavimento, hoje parcialmente descaracterizado por sua repartição em novos cômodos, deve ter existido além do porão, uma cozinha e também o dormitório de escravos, ao menos daqueles mais ligados às atividades domésticas. Do madeiramento empregado em sua construção, apenas sua estrutura externa, esteios e frechais em braúna, resistiram bem à deterioração. Paredes internas, de menor espessura, em pau-a-pique, e as demais feitas de adobe.

Dos equipamentos remanescentes do café, resta uma pequena casa-de-máquinas para onde os frutos eram conduzidos pela água em canaletas de pedra, e ali despolpados mecanicamente. Esta operou até o início dos anos de 1960, quando os últimos pés-de-café da propriedade foram cortados.

\section{Fazenda da Aurora}

Distante apenas $2 \mathrm{Km}$ a nordeste do povoado de Caeté, a fazenda é produtora de leite e goiaba, destinados à fabricação de doces. A região na qual se situa
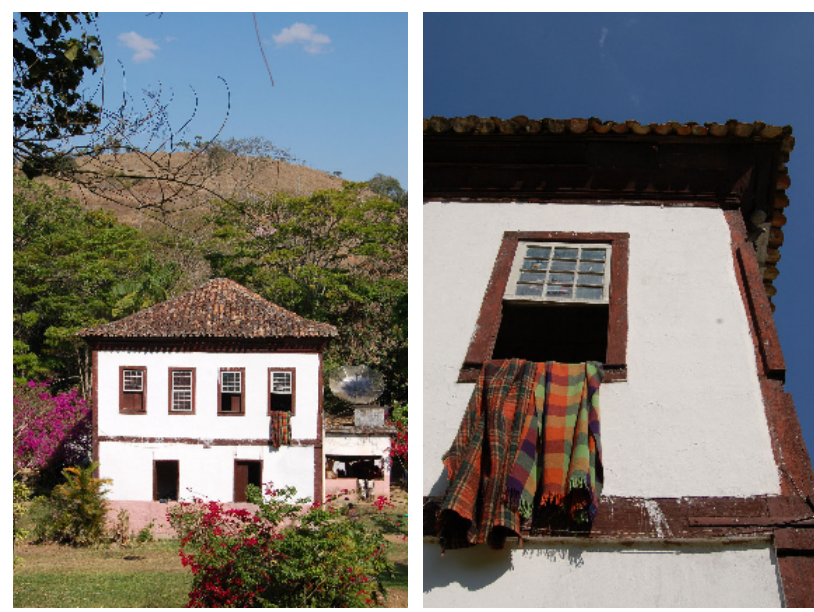

Vista lateral da casa-sede e detalhe de sua estrutura em braúna. Crédito: Autor

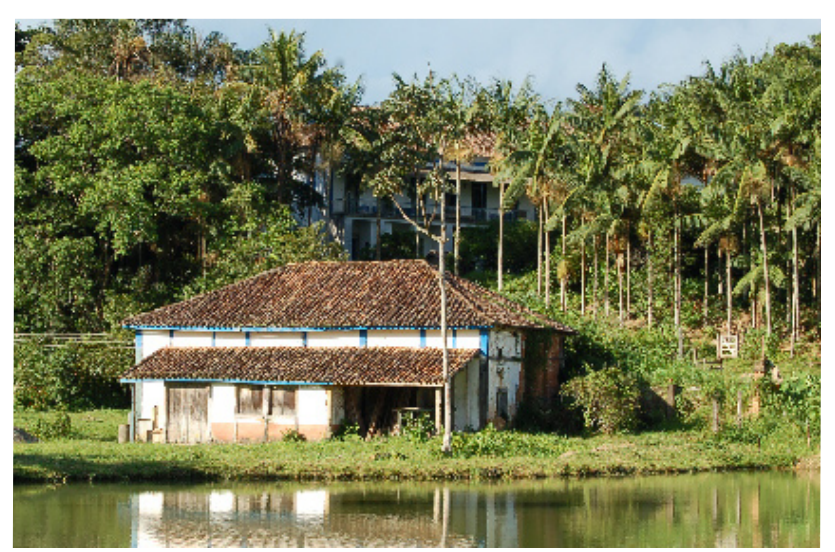

Vista, a partir da estrada pública, da antiga tulha da Fazenda da Aurora. Ao fundo, em meio à vegetação, sua casa-sede. Crédito: Autor 


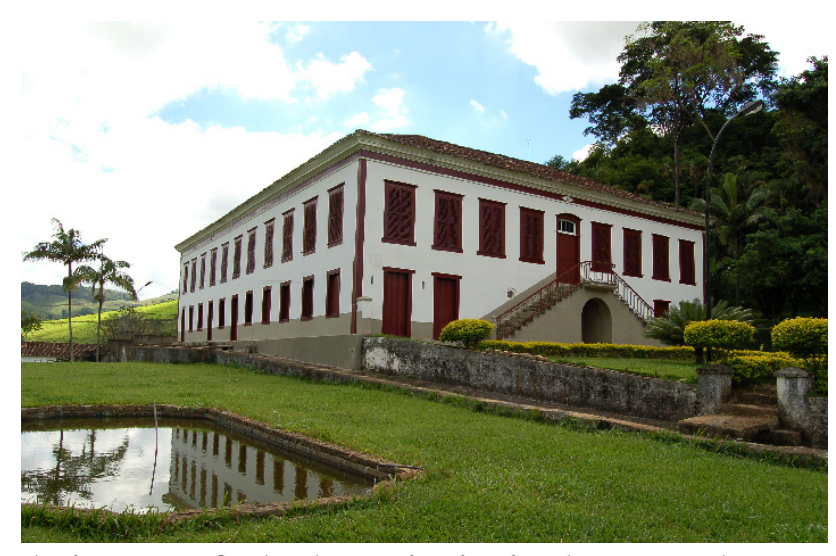

Acima, as fachadas principais da Fazenda Boa Vista, a partir de seu jardim. Abaixo, seus fundos, voltados à meia-encosta florestada. Crédito: Autor

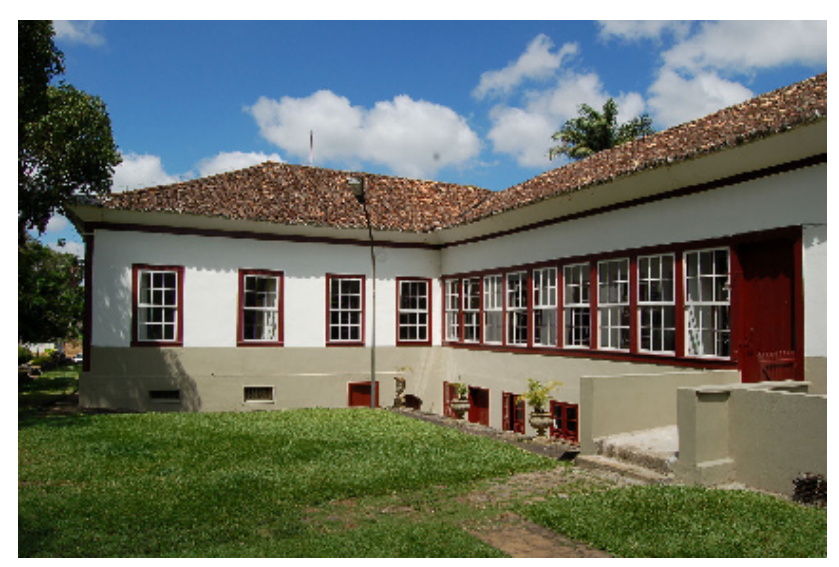

é marcada por uma topografia mais favorável, por conta da ampla várzea que contém o Córrego Caeté.

A casa-sede da Aurora, guarnecida por um denso palmital, passou por pequenas reformas que a descaracterizaram parcialmente.

\section{Fazenda Boa Vista}

Prosseguindo além da Aurora, em sentido contrário ao das águas do Córrego Caeté, e junto deste, encontra-se a Boa Vista, que se estende também por vastas terras situadas ao norte do distrito de Sarandira, no município de Chácara, totalizando cerca de 1500 hectares. No passado foi a maior e mais importante produtora de café do distrito de Sarandira, e hoje desponta como sua maior criadora de gado de corte.

Em 1915 ESTEVES (p. 473) relatou a existência na fazenda de máquinas para o beneficiamento de café, arroz e laticínios, embora não se encontrem hoje sinais de sua presença. Há ainda uma bem conservada senzala, convertida em moradia para algumas famílias de colonos. Também um paiol e uma capela, ambos de importante valor histórico.

Datada de 1871, a residência principal encontrava-se há pouco mais de dez anos em estado avançado de deterioração, estando agora inteiramente recuperada.

\section{Fazenda Belmonte}


De acordo com PROCÓPIO FILHO (1973, p. 86) "Foi uma das mais importantes, extensas e suntuosas fazenda do município", e ainda: "Infelizmente, como aconteceu com a grande maioria daquelas luxuosas fazendas, do Belmonte apenas ruínas hoje encontramos."

A sede da Fazenda Belmonte, embora nos mapas esteja representada sobre os limites de Juiz de Fora, pertence oficialmente à Matias Barbosa. Preteritamente, antes de ocorrerem sucessivos desmembramentos, uma boa parte de suas terras espalhava-se sobre o distrito de Sarandira. Como efeito, a porção sudoeste do distrito é chamada de Belmonte, e a sede da fazenda liga-se mais fortemente à Caeté, de quem dista menos de $2 \mathrm{Km}$, do que do centro de Matias, distante pouco mais de $6 \mathrm{Km}$.

O que restou de seu conjunto arquitetônico impressiona. A casa-de-máquinas, que possivelmente também servia como tulha, foi construída em alvenaria de pedra e ricamente adornada. Nela ainda pode ser visto parte do maquinário, como o separador e ventilador "Lidgerwood" usado no processo de produção. Desta ligada por um longo terreiro de café, a casa-sede, datada de 1877, foi construída nos moldes de um palacete, com ares ecléticos. Ambas contrastam com as demais propriedades da região e sua arquitetura colonial. Ainda fazem parte do conjunto construções em estado precário de conservação que abrigaram, escola, armazém e casa de encarregado.

A casa-sede sofreu interferências recentes em sua parte posterior, ampliações que abrigam entre outros itens, área de lazer e garagem. Sua fachada permanece ainda bem preservada, à excessão das janelas e outras peças em madeira que foram danificadas por maritacas, problema rotineiro em toda a região.

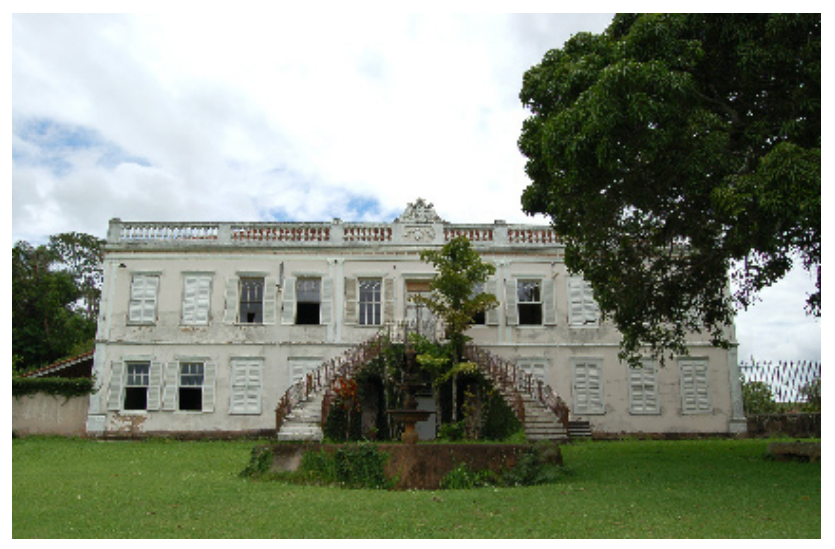

Imponente fachada da Belmonte, com fonte em primeiro plano e mangueira centenária ao lado. Crédito: Autor
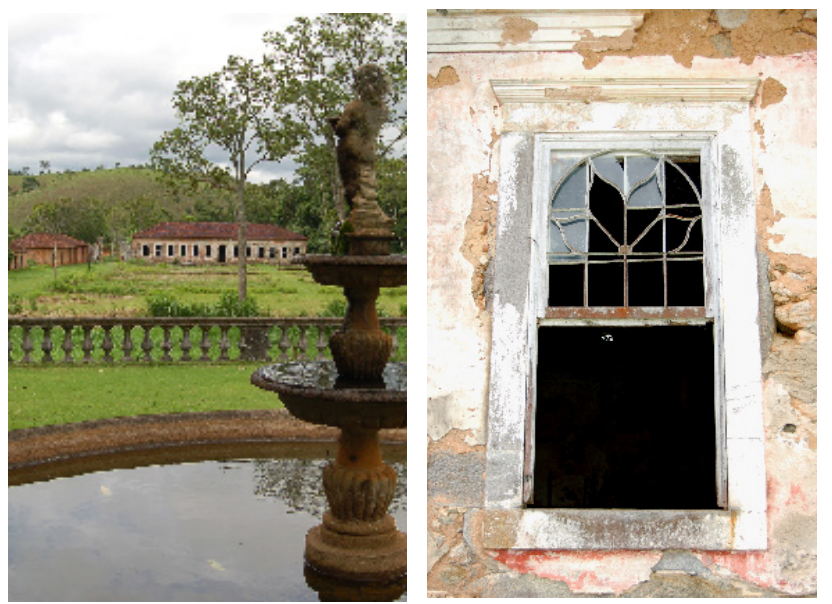

Vista obtida do jardim - situado num patamar superior - voltada à casa-de-máquinas. $\mathrm{Na}$ imagem ao lado, uma das rebuscadas janelas da casa-de-máquinas em detalhe. Crédito: Autor 


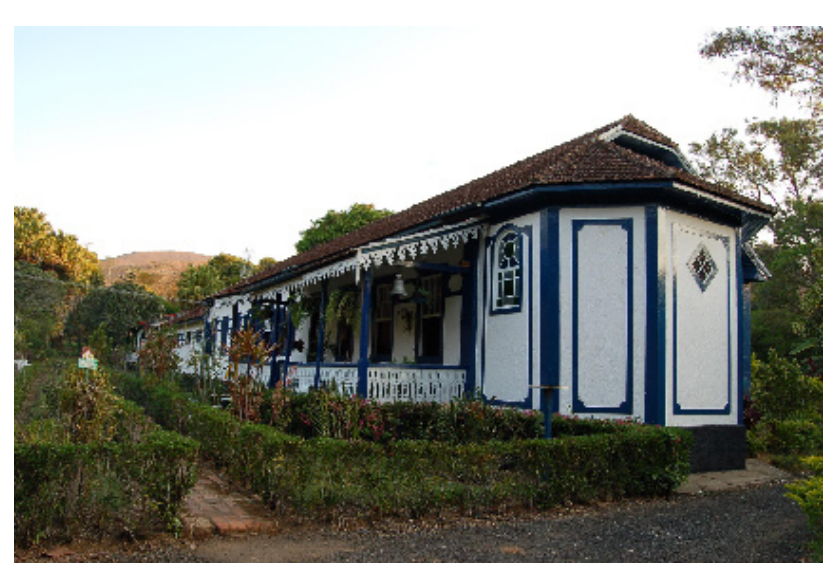

Recreio: Antiga tulha de café convertida na residência principal da propriedade. A edificação encontra-se em ótimo estado de conservação. Crédito: Autor

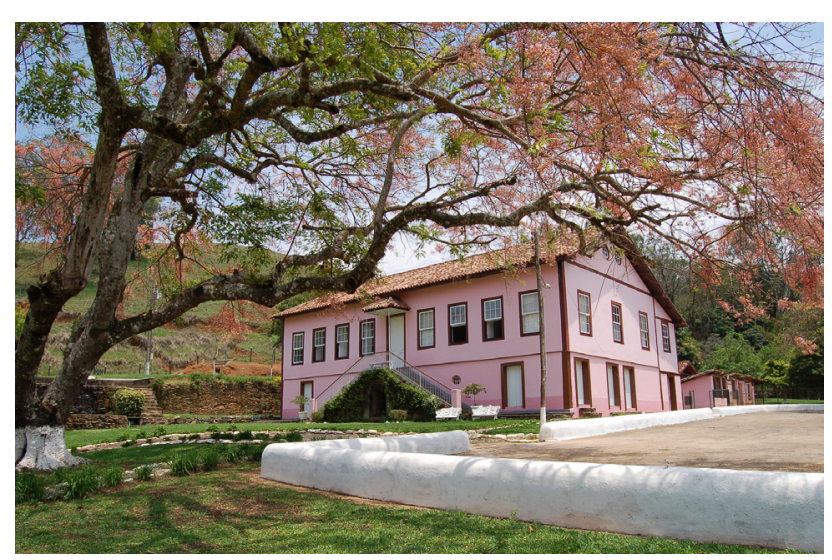

Vista oblíqua da Fazenda Pouso Alegre: conjunto bem preservado, composto pela casa-sede e o terreiro de café. Crédito: Autor

\section{Fazenda Do Recreio}

A Fazenda do Recreio, outrora também pertencente à referida Sesmaria de Santa Luzia , e dela desmembrada em 1877, está situada ao sopé da Serra do Mina, em sua face sul, região de terras consideradas como das mais férteis do distrito, junto à divisa do município de Matias Barbosa. Apesar de sua grande produtividade à época do café, curiosamente não possuía uma casa-grande. Somente em 1959, sua tulha, onde era armazenada a produção daqueles grãos, foi convertida na residência principal da fazenda. Destaca-se nessa propriedade sua grande mata, com mais de 150 hectares.

De acordo com levantamento do IBGE realizado no ano 2000, das doze habitações pertencentes à Recreio, apenas cincoestavam sendo permanentemente ocupadas. Relação comum à totalidade das fazenda da região, e que bem ilustra a decadência econômica característica da atualidade.

\section{Fazenda Pouso Alegre}

A fazenda situa-se junto à estrada Caeté-Sarandira, à meia distância entre estes dois povoados. Sua fachada principal, voltada para o leste, teve sua orientação subordinada à localização da estrada municipal, para a qual está voltada. Esta é uma característica comum às propriedades do entorno, em detrimento da melhor posição em relação à insolação, foram voltadas aos olhares dos que transitavam pelas estradas locais. A opção pela cor de suas paredes, ao contrário do branco que é mais comumente empregado, parece se justificar ao final de cada ano, com a florada das frondosas cássias de seu jardim. 
A edificação escontra-se em bom estado de conservação, não evidenciando qualquer intervenção impactante em sua forma original, como as tão comuns ampliações e subtrações.

A fazenda, em 2000, segundo levantamento do IBGE, abrigava um total de sete habitações, sendo apenas uma efetivamente ocupada.

\section{Fazenda São Lourenço}

Localizada a pouco mais de $1 \mathrm{Km}$ a nordeste da Pouso Alegre esta fazenda possui uma das maiores casas-grandes da região, e guarda grande semelhança arquitetônica com aquela da Fazenda Boa Vista. É composta por dois amplos pavimentos, o inferior um porão alto de dimensões generosas, que no passado abrigava escravos. Não há sinais da presença de uma senzala externa ao casarão, embora, pela imponência da propriedade, presume-se haver existido.

A visão oblíqua que se tem da casa, a partir da estrada, sugere uma planta em formato quadrangular, e apenas quando se adentra à edificação percebe-se sua conformação em "L". Com esse artifício ostenta-se à entrada uma volumetria mais grandiosa, enquanto que ao fundo a forma resultante revela por completo um corpo de proporções mais enxutas. Nesta sede, também a exemplo da grande maioria dos casarões desse período, o emprego abundante de janelas é um recurso freqüiente que garante não apenas maior iluminação e ventilação mas também confere maior leveza e movimento às fachadas, harmonizando sua relação entre cheios e vazios.

Totalmente abandonada, esta edificação corre sérios riscos de ruir. As paredes
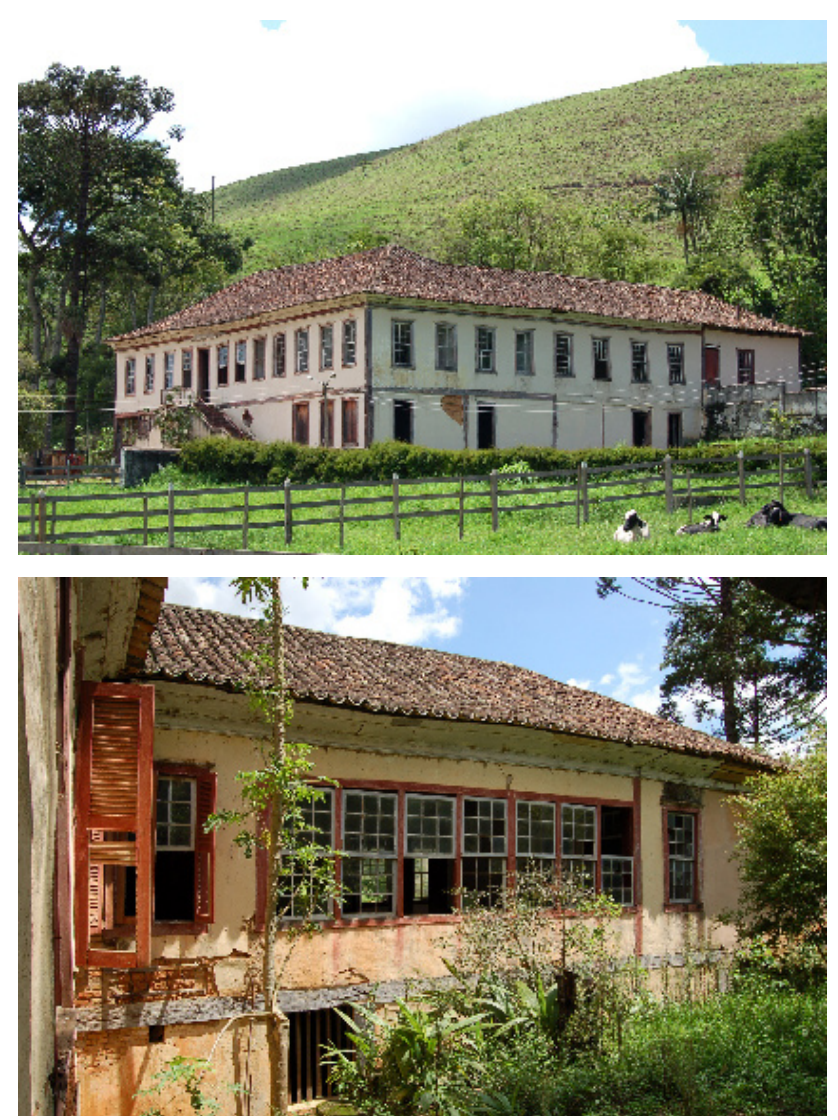

No alto, as fachadas principais da Fazenda São Lourenço. Abaixo, detalhes de sua fachada sul onde, iluminados por grandes janelas, ficam o salão e o oratório, onde eram rezadas as missas dominicais. Crédito: Autor 

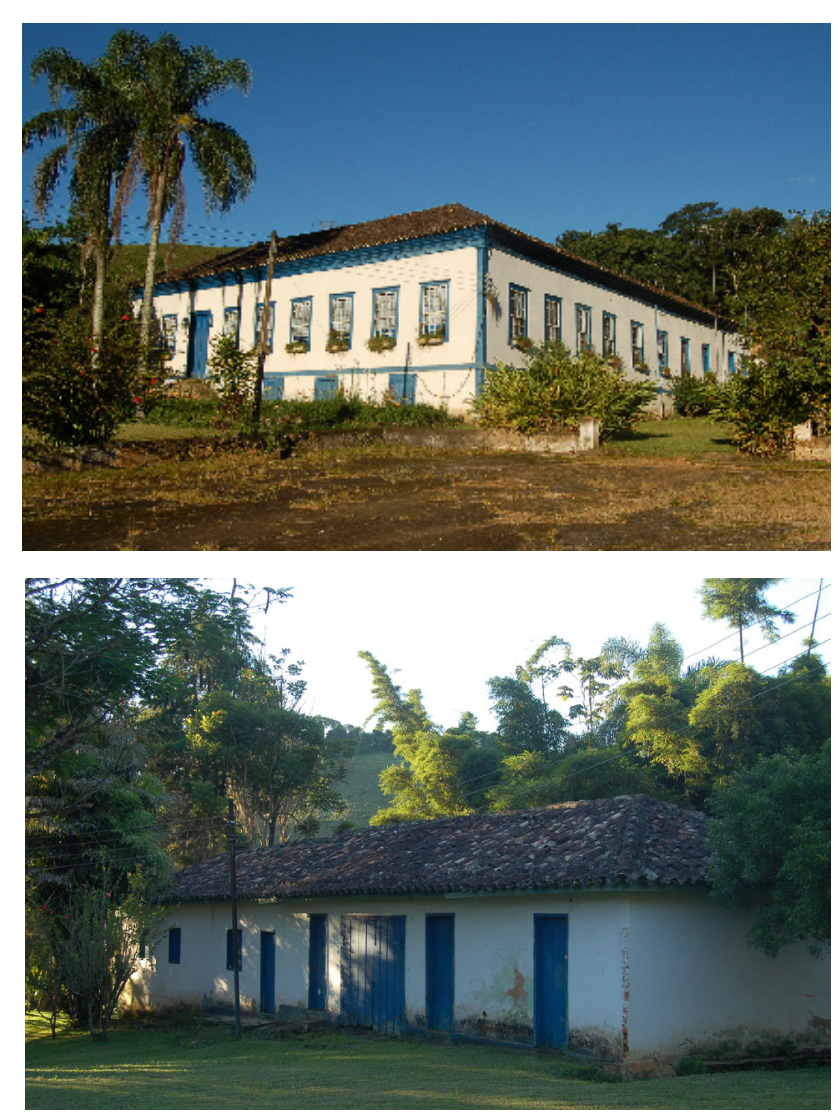

A Fazenda Santana. No alto, vista oblíqua de sua casa-grande, tendo em primeiro plano, o terreiro de café para onde Roberto Burle Marx destinou um projeto paisagístico que não veio a ser executado. Em sua lateral oposta situa-se uma das raríssimas senzalas preservadas da região, mostrada na imagem seguinte. Crédito: Autor de adobe e de pau-a-pique estão severamente deterioradas, tabuado de cedro e barrotes de angico em estado extremamente precário de conservação. Apenas esteios e frechais, em braúna, resistiram firmemente. Em uma recente reforma emergencial o telhado foi parcialmente refeito, e as centenárias ripas de palmito apodrecidas foram substituídas por delgadas peças de eucalipto, conferindo-lhe uma sobrevida de uns poucos anos mais.

A fachada principal, voltada para o norte, tem sobre seu alpendre a inscrição 1887, referente ao ano de sua construção ou, como afirma o atual encarregado desta propriedade, a data de sua reforma, sendo ela, portanto, ainda mais antiga. Ainda segundo seu relato, havia uma elaborada estrutura para a produção do café.

De acordo com levantamento do IBGE realizado no ano 2000, das treze habitações pertencentes à São Lourenço, apenas seis estavam sendo permanentemente ocupadas.

\section{Fazenda Santana}

A Santana é uma grande propriedade situada a cerca de $4 \mathrm{~km}$ ao norte da vila de Sarandira, nas proximidades do Rio Cágado situado a leste.

Possui uma casa-senhorial muito bem conservada, com planta em "L", e fachada principal voltada a oeste. A implantação obedece ao padrão típico das fazendas da época, sobre meia-encosta, resguardada aos fundos pelos morros em forma de anfiteatro, e elevando-se à frente, sobre um porão alto. Solução construtiva que propiciava não apenas o maior aproveitamento do espaço com o acréscimo 
do porão - e mantendo também livre da umidade o pavimento principal mas, não obstante, constituindo também um recurso cenográfico, que tornava assobradada, e portanto mais imponente, a fachada voltada à estrada pública. Aposto a esta, um amplo espelho d'água forma outro elemento de composição paisagística muito utilizado localmente.

Ainda com relação à sua implantação, era padrão em todas as sedes a distribuição em quadra dos equipamentos pertencentes à estrutura produtiva cafeeira. Situam-se assim sobre eixos ortogonais todas as suas edificações.

\section{Fazenda Passo da Pátria}

Esta propriedade rural de quase 400 hectares localiza-se à extremidade norte do distrito, atravessada pela rodovia BR-267, e faz divisa com os municípios de Chácara e Bicas.

Por sua alta produtividade no passado e sua dimensão, que foi de 1.000 alqueires (quase 5.000 hectares), a fazenda acabou dando nome àquela região, onde hoje situam-se propriedades oriundas de seus sucessivos desmembramentos. Seus proprietários estimam que a fazenda seja datada do início do século XIX.

A casa-sede vem sendo bem conservada, com suas paredes e madeiramento íntegros, a despeito de sua idade. As descaracterizações ficaram por conta de sua redução, passando de uma volumetria em "L" para a retangular em período não determinado, mas posterior à década de 1930, e pequenas reformas internas datadas da década de 1950.

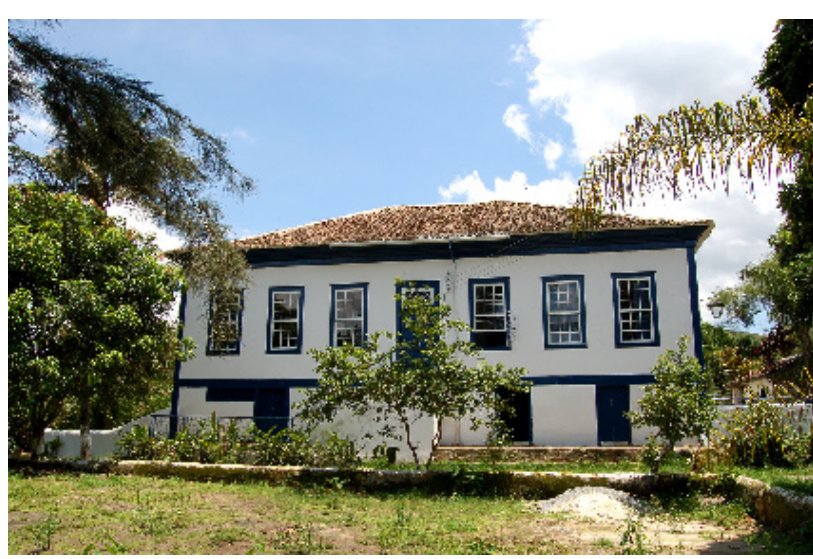

Acima, a Passo da Pátria. Abaixo, a fazenda em dois momentos: 2007 e 1930. Crédito: Autor
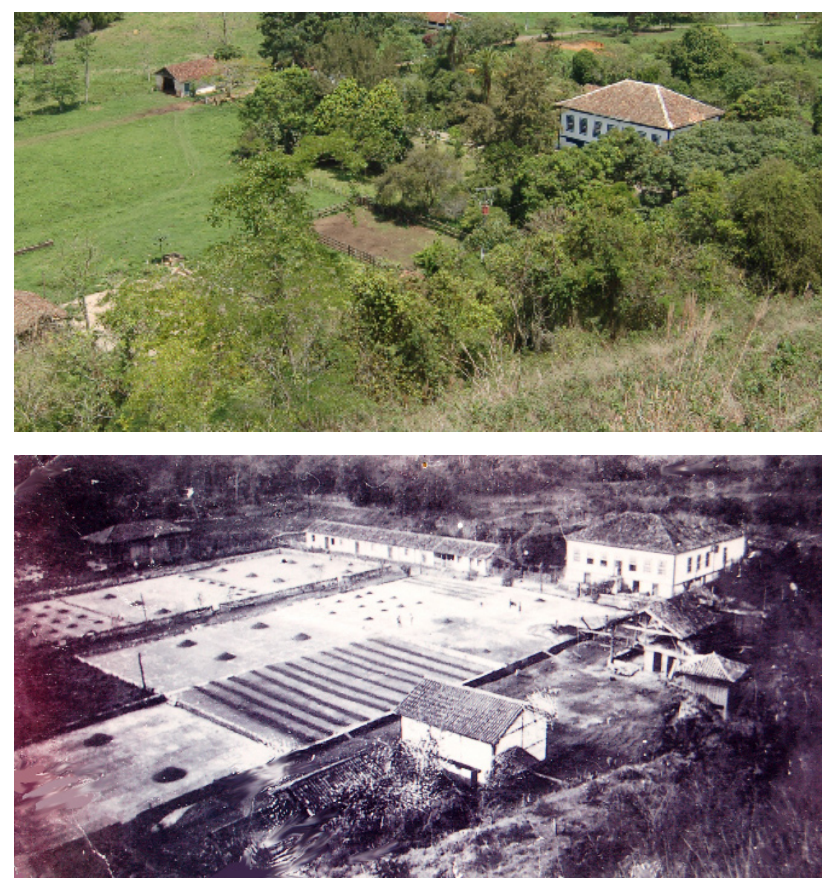


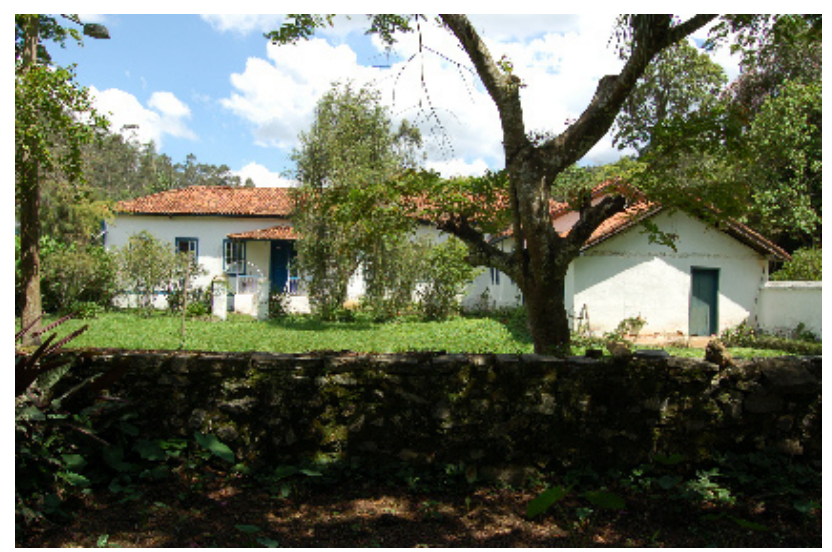

Vista da casa-sede da Fazenda Boa Sorte a partir de seu jardim. Crédito: Autor

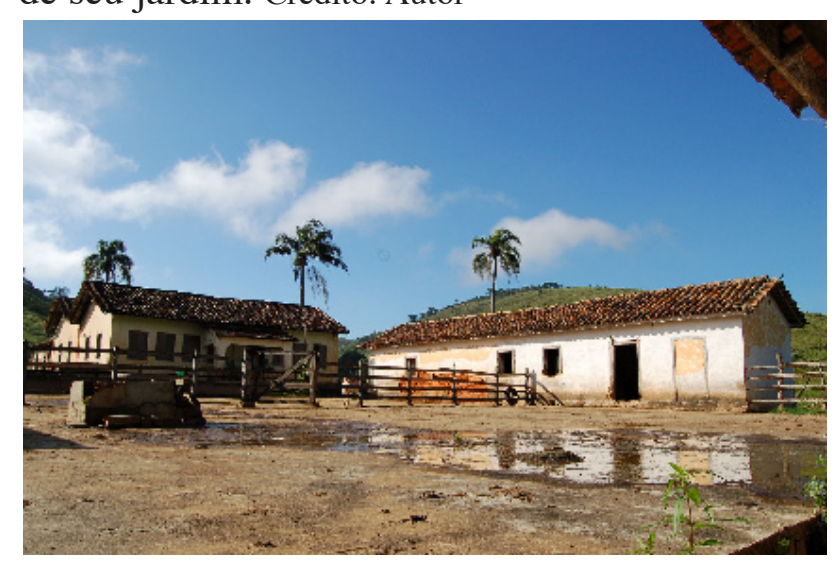

Curral da Fazenda São Marcos, e residência principal ao fundo. Crédito: Autor
As edificações que foram utilizadas para a produção cafeeira encontram-se parcialmente destruídas. Ainda podem ser vistas, em meio à vegetação ruderal, as canaletas de pedra que conduziam o café com o desvio de um leito d'água até os terreiros de secagem. Estes, também feitos de lajes de pedras, eram ainda cobertos por uma fina camada de terra que ajudava a manter os grãos sob uma temperatura controlada. Hoje tornaram-se pastos. Contam seus proprietários que até meados da década de 1950, portanto já em meio à franca queda da economia cafeeira, até sessenta homens ainda trabalhavam em suas lavouras.

\section{Fazenda Boa Sorte}

Residência com planta em "L" passou por algumas reformas que parcialmente a descaracterizaram. Por iniciativa de seu atual proprietário, como principal fonte de renda desta fazenda, a criação de gado vem dando lugar à comercialização de água mineral engarrafada. Empreendimento pioneiro de exploração na região deste farto recurso natural.

\section{Fazenda São Marcos}

A fazenda, de fins do século XIX, apresenta casa-sede construída no início do século XX. Hoje sua estrutura presta-se à pecuária.

\section{Sítio Boa Vista}


Casa sede extremamente bem conservada, datada de 1934.

\section{Moradias de colonos}

Também compõem as fazendas construções variadas, como currais, estábulos, paióis, mangueiros de porcos, galinheiros e tulhas. Mais comuns no passado, também escolas, senzalas, enfermarias e vendas. Neste conjunto, por sua abundância, destacam-se as casas de colonos.

Algumas delas são remanescentes do final do século XIX, embora a grande maioria seja mais nova. Em ambos os casos, o traço mais marcante que as une é seu abandono.

Estas residências costumam ser mais permanentemente ocupadas pelo encarregado da fazenda e sua família, e ainda de forma significativamente mais transitória pelos demais empregados, em especial jovens solteiros, que gravitam de fazenda em fazenda, de emprego em emprego, com grande velocidade.

Basicamente, desse caráter mais ou menos transitório de ocupação, derivam residências bastante distintas. Assim, ainda que haja exceções à regra, de forma geral as moradias com famílias já estabelecidas há alguns anos são melhor conservadas, dispondo de estrutura mais variada, como horta, pequeno pomar, galinheiro, entre outros. As reformas e ampliações nestas casas não são raras, acompanhando o crescimento da família e de suas necessidades. Por outro lado, há casas que não recebem qualquer reparo ou melhoria. Quando são ocupadas, é quase sempre por pouco tempo, provisoriamente. São testemunhos e símbolos do esvaziamento da zona rural.

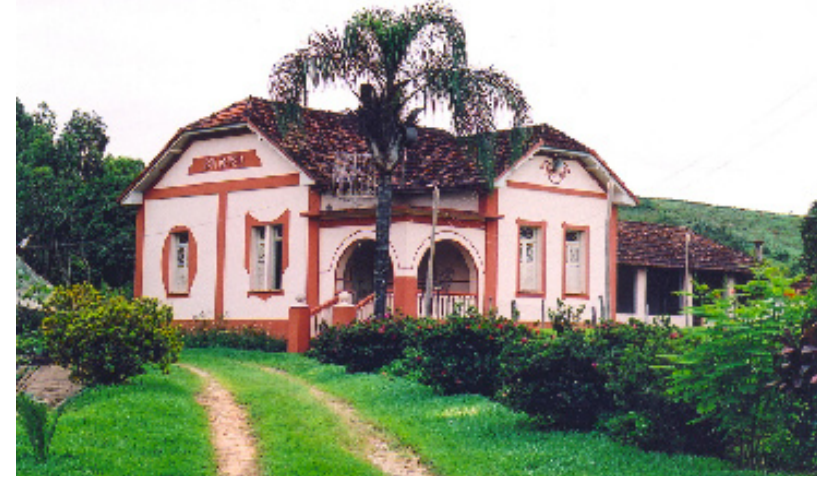

Casa-sede do Sítio Boa Vista. Crédito: Autor
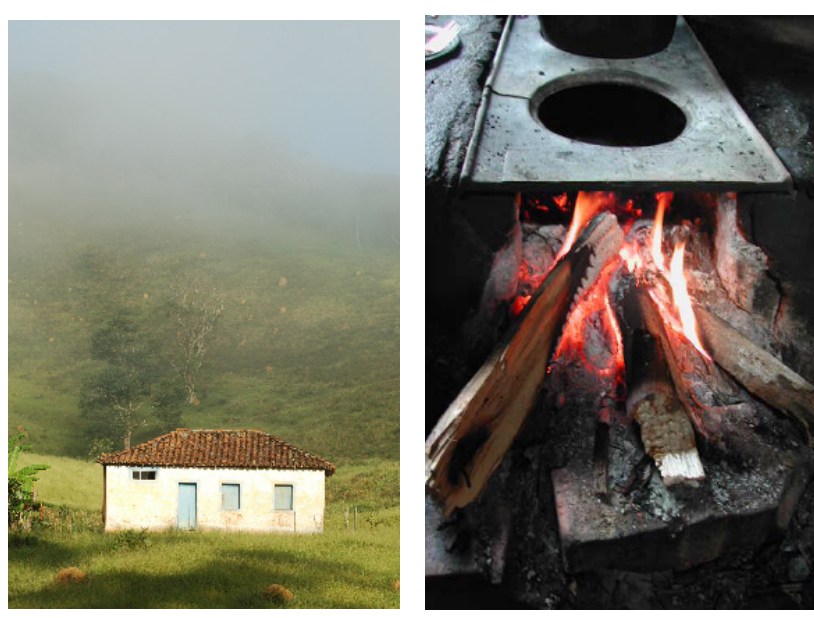

Casa de colono fechada, a oeste da vila de Sarandira. E o fogão-de-lenha, sempre aceso, nas moradas ainda ocupadas. Crédito: Autor 

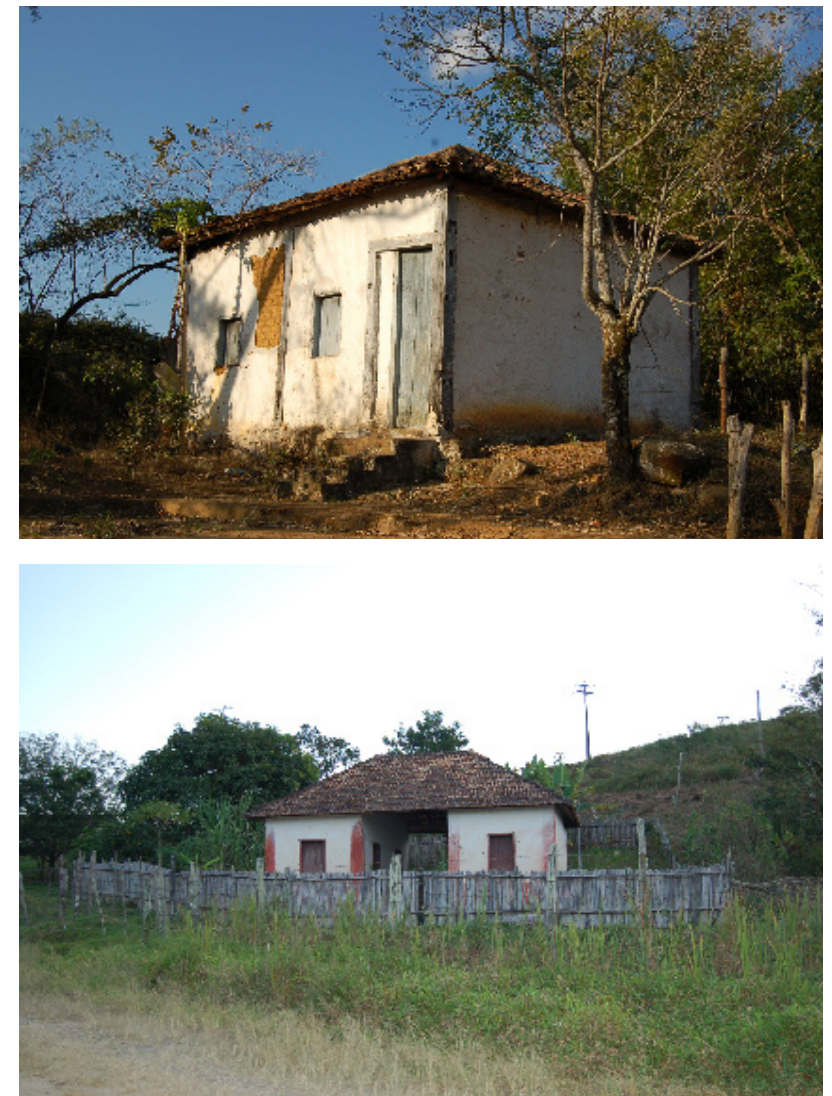

No alto, típica casa de colono, ocupada por pequeno sitiante. Abaixo, uma característica senzala de pequenas dimensões, hoje convertida em casa de colono. Crédito: Autor
Seu sistema construtivo tradicional costuma partir de uma planta retangular de dimensões radicalmente enxutas, erguendo-se em pau-a-pique ou adobe, rebocados e caiados, recebendo ainda ripamento de palmito e telhas artesanais em sua cobertura.

São representantes da arquitetura mais simples, ao mesmo tempo em que são expressões engenhosas de adaptação às condicionantes climáticas da região e à disponibilidade de matéria-prima necessária para sua construção e manutenção. 


\subsubsection{Povoados}

Como visto no capítulo anterior, os dois povoados do distrito de Sarandira, foram importantes núcleos econômicos, sociais e religiosos para as propriedades cafeeiras circundantes. Surgiram a reboque dessas últimas e, com elas, também sucumbiram.

Suas construções tiveram destino semelhante, mas há ainda diferenças importantes entre o patrimônio remanescente nos arraiais e nas fazendas.

Como já descrito anteriormente, na exclusiva dependência da produção rural da região, os povoados - especialmente a vila de Sarandira - perderam sua fonte alimentadora com o fim da cafeicultura. Já as fazendas mantiveramse como unidades relativamente autônomas, ainda que empobrecidas. Os pequenos prestadores de serviços que residiam naqueles dois agrupamentos populacionais abandonaram suas construções e foram em massa para as cidades mais próximas, especialmente Juiz de Fora. Os poucos que ficaram, ali estavam ilhados. Residências e comércio se deterioraram e foram demolidos.

Entre seus fragmentos históricos, restaram seus arruamentos, espinhas dorsais desses antigos núcleos, e algumas raras edificações. Entre essas, suas duas igrejas e uma ou outra residência.

\section{Igreja Nossa Senhora do Livramento}

Ocupando a parte mais elevada da vila de Sarandira, sobre relevo bastante
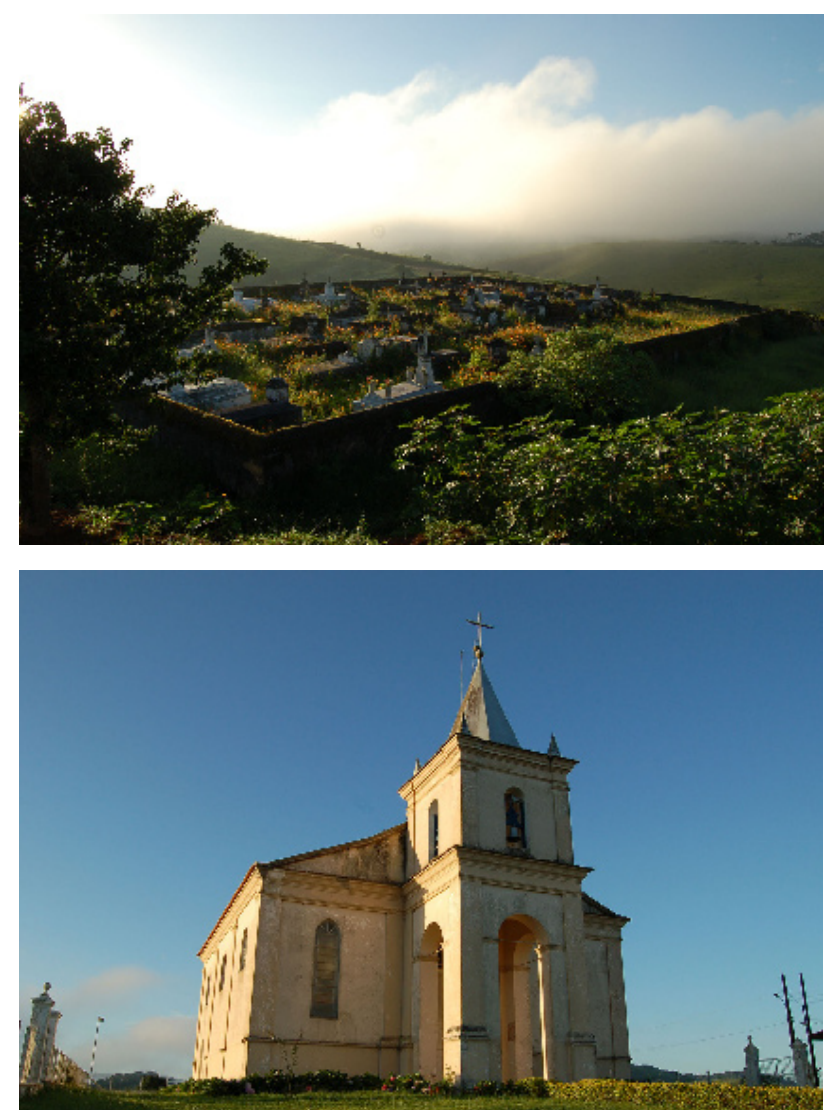

No alto, o cemitério da vila de Sarandira, localizado nos fundos da Igreja Nossa Senhora do Livramento, mostrada abaixo. Crédito: Autor 


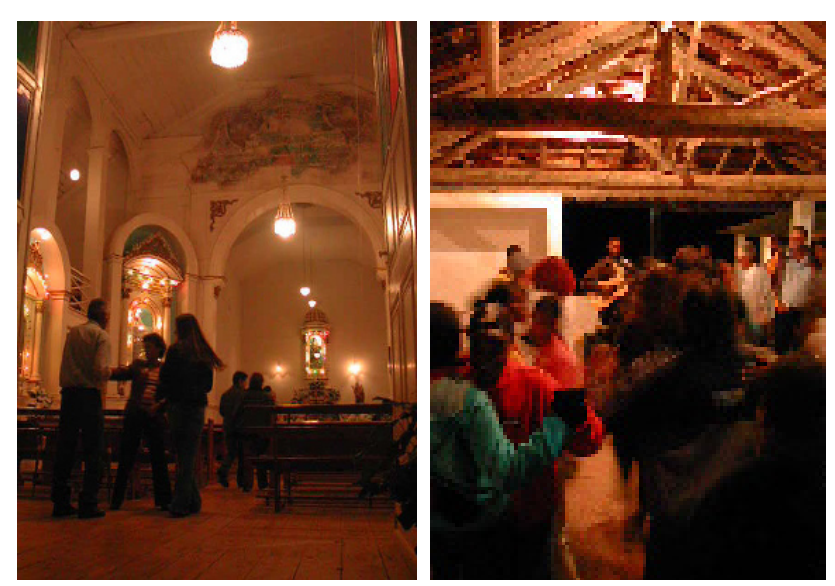

O interior da igreja da vila de Sarandira, e ao lado, baile na noite de festa de sua padroeira. Crédito: Autor

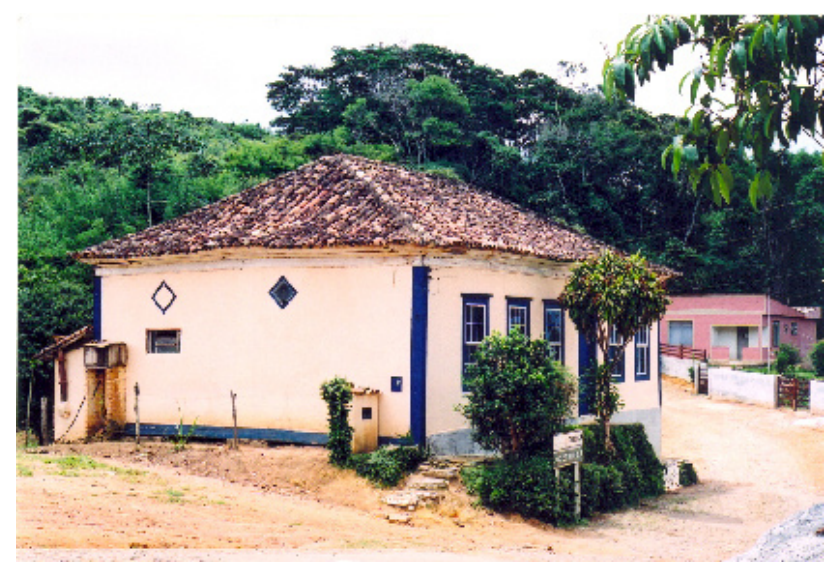

Casarão de esquina na vila de Sarandira. Crédito: Autor montanhoso, sua visão é impressionante. É a partir da capela, a exemplo típico de muitas outras povoações mineiras, que se organiza o povoado.

A edificação, datada da década de 1850, encontra-se razoavelmente íntegra, e foi tombada pela Prefeitura Municipal de Juiz de Fora em 2004 mediante a solicitação da comunidade local, organizada através da Sociedade PróMelhoramento de Sarandira

\section{Casarão na vila de Sarandira}

O casarão de esquina, situado na Rua Santana, sem número, é o último remanescente da arquitetura residencial da primitiva vila.

A residência, em " $L$ ", ergue-se sobre porão alto de pedra, estrutura de madeira e vedação em adobe e pau-a-pique. Seu sistema construtivo e seu partido arquitetônico se assemelham aos das fazendas cafeeiras de seu entorno.

Em 2006 esta edificação teve sua fachada e volumetria tombadas pela Prefeitura Municipal de Juiz de Fora.

\section{Igreja São Francisco e seu entorno.}

O conjunto formado pela Igreja São Francisco, cuja construção data de 1860 a 1861, e sua praça adjacente, situados no local popularmente conhecido como "largo" representam o núcleo primitivo daquele povoado.

A referida capela, embora tenha sido tombada em 1987, mediante solicitação 
da comunidade local à prefeitura de Juiz de Fora, sofreu desde então reformas que a descaracterizaram. Em seu entorno imediato, ao longo de três testadas, localizam-se pequenas residências, algumas poucas entre elas conservando traços genuínos do período de sua construção.

A igreja, tombada em 1987, já se encontrava naquele ano bastante descaracterizada, e em seu decreto de tombamento já era manifestada a intenção de recuperar suas feições originais. Algo que ainda não ocorreu.
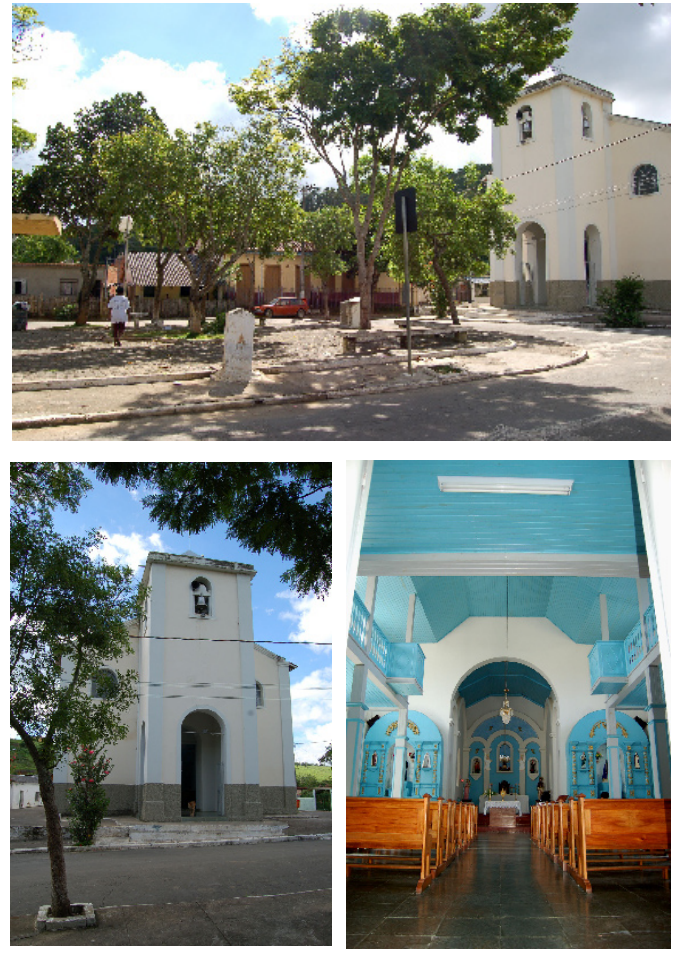

No alto: vista parcial do largo, onde situam-se a igreja São francisco e algumas outras edificações igualmente possuidoras de valor histórico e, portanto, passíveis de iniciativas voltadas a sua recuperação.

Mais abaixo: detalhes da fachada e interior da igreja. Crédito: Autor 


\subsection{Paisagem}

Transpondo a mancha urbana de Juiz de Fora e rumando para as terras de Sarandira, os últimos bairros periféricos são deixados para trás. Adjacente à rodovia federal onde circulam apressados, carros, ônibus e caminhões, à entrada de uma estrada vicinal uma placa indica a direção do povoado de Caeté, distante ainda alguns quilômetros. Adentra-se um espaço cujas paisagens sugerem um ritmo de vida desacelerado. A fruição não se dá apenas no espaço: as marcas de sua apropriação também nos remete a diversas épocas. Viaja-se no tempo.

Trafegando por uma via bucólica, à sombra de angicos e mulungus, a periferia urbanizada dá lugar a um cenário indubitavelmente rural, subtamente pontuado por dois loteamentos ainda não totalmente ocupados. No segundo deles, a indicação "Fortaleza", em referência à portentosa fazenda cafeeira do século XIX da qual sequer restaram ruínas, parece ter sido esquecida, em meio ao afã de sua conversão em várias pequenas granjas, onde reluzem ao sol, piscinas, para-brisas e coberturas de zinco.

Logo, a visão da Fazenda Garanjanga, pouco à frente, temporariamente reafirma os ares de ruralidade então abalados. No entanto, o mugido das vacas, o trânsito de homens a cavalo, ou ainda carregando ferramentas agrícolas apoiadas sobre os ombros, pode-se dizer, não prenunciam a imagem idealizada do povoado de Caeté, a ela aposto após uma ligeira subida em curva.

Neste, casas vão sendo erguidas, rebocadas e pintadas. Moradores antigos e recém-chegados se cumprimentam cordialmente, jogam conversa fora ou combinam algum serviço. A rua é tomada como espaço das relações sociais. 
Também nela, crianças jogam bola, jovens saem para paquerar e homens se reúnem nos bares, estacionando bicicletas, carros e cavalos. Às portas, cachorros dormem preguiçosamente, enquanto das janelas, donas de casa colocam seus assuntos em dia.

Igualmente diversificadas são as edificações, alternando-se casas térreas com outras de até três pavimentos, algumas pintadas, outras com revestimento cerâmico, umas cobertas por telhas de barro, outras com laje aparente.

Esse é o destino final da maioria daqueles que passam por aqui. Desse ponto em diante saímos do núcleo urbano de Caeté, abandonando o asfalto, cruzando por estradas de terra alguns sítios e fazendas em direção à vila de Sarandira. A aglomeração residencial do povoado dá lugar a construções esparsas, como a da Fazenda da Laje. Mas um dos aspectos mais gerais de sua fisionomia não se altera, seu relevo extremamente movimentado, e a sinuosidade das estradas, talhadas de forma a amenizar a transposição de suas serras. Esse serpentear do deslocamento chega a causar certa desorientação aos não familiarizados com a região, ao mesmo tempo em que condiciona a constante insinuação de visões emergentes, de segmentos de paisagem que se anunciam por antecipação, dinamizando o trajeto.

Em alguns trechos, como após a íngreme subida que precede a Fazenda Vargem Alegre, essas mesmas características serão responsáveis pelo descortinamento de uma ampla paisagem que se estende na direção sudoeste por dezenas de quilômetros, limitada pela Serra do Mina, e configurando o vale onde situamse as fazendas Santa Luzia e Recreio, entre outras cerca de doze pequenas propriedades. Atesta-se a materialização de quase três séculos de intensa lida com a terra, numa sucessão de pastos, gado, campos arados, capineiras, 
plantações, capoeiras, casas, currais, estábulos e paióis, unidos a partir deste ponto de vista privilegiado. Nessas construções históricas, os telhados fletidos, o madeiramento sulcado, as paredes esconsas, as quinas quebradas, os rebocos desprotegidos, os muros de pedra recobertos de musgo, em todos os aspectos, o trabalho do homem do campo revela-se progressivamente mais integrado à natureza, inexoravelmente destinado a retornar à terra, a desaparecer.

A penosa subida enclausurada entre morros e o posterior descortinamento deste vasto cenário, culminando em desfecho pitoresco, criam uma associação dramática, ainda que seja difícil precisar o que tanto atrai nesta longa visada. Do alto, o olhar supera os limites administrativos que compartimentam o território, bem como integra suas micro-bacias, na qual repousam em relativo isolamento, as sedes das propriedades e seus entornos. Estas, denunciando a clara preferência por sua implantação nos piemontes, livres da umidade das baixadas, bem como dos ventos e acesso dificultado das cotas elevadas, fundemse à matriz de pastagens, salpicadas por árvores isoladas e, nas partes mais altas, por encraves de matas, que secundariamente também ocupam as escarpas mais inclinadas, acompanhando timidamente os ribeirões e as divisas entre propriedades. Pela ação da gravidade, os filetes d'água que brotam fartamente à meia-encosta, carreando partículas de terra ou merejando sobre afloramentos rochosos, unem-se rapidamente aos talvegues, e ao final de um dia já integram com folga as correntes do Paraíba do Sul. No total, são menos de cinco dias até que elas atinjam o oceano, retornando posteriormente em forma de chuva, num processo contínuo. Dessa relativa proximidade com o mar, numa macrovisão, decorrem suas particularidades fitogeográficas. Uma flora integrante do sistema atlântico, que se recompõe com o vigor característico dos estágios sucessionais iniciais, onde a competição entre os vegetais resulta em maciços florestados 
quase intransponíveis.

Vistos em perspectiva, os morrotes arredondados que lembram meias-laranjas vão se achatando e se aglutinando no horizonte, quando simultaneamente o verde da braquiária, filtrado pela umidade vaporosa e por partículas em suspensão, tende a um azul-acinzentado. Neles, quando próximos do observador, ainda podem ser percebidas as pequenas depressões das covas antes ocupadas pelos pés de café, destacadas pelos raios mais inclinados do Sol. Nesses instantes também sobressaem os extensos valos que demarcavam os limites das propriedades quando ainda ainda não haviam cercas de arame farpado, hoje onipresentes na região. É ainda por conta da luminosidade, do semi-círculo da trajetória solar incidindo sobre esse palco profundamente dissecado por milênios de intemperismo, que o desenho das sombras, sempre cambiante, confere movimento `a cena.

A serenidade condicionada pelo distanciamento do observador à maioria dos elementos contemplados não chega a ser abalada pelo vento constante, que sibila ao atravessar os capins. Tampouco pelos sons de motores, dos poucos veículos que passam ao longe pelas estradas, ou das picadeiras de capim, que anunciam, antes mesmo dos galos, o início da jornada de trabalho. Vacas, cães, passarinhos e seriemas, cada qual a sua maneira, enriquecem essa experiência, num concerto inusitadamente harmônico.

Alguns cheiros vulgares à vida no campo complementam a percepção desta paisagem, como o cheiro do mato, da terra molhada, do curral, e de madeira queimada que, assim como os sons, vagam ao sabor do vento.

Uma longa descida completa a transposição da serra, e logo se atinge a Fazenda Pouso Alegre. Por mais cerca de 6 ou $7 \mathrm{Km}$, o trajeto principal corta diversas 
propriedades, entre as quais a Fazenda Cristal, dividindo-se em três caminhos que levam a outros pontos do distrito. No total, sete estradas levam à Sarandira, o que sugere sua importância como centro econômico à época das lavouras de café.

Vencida a última encosta, situada quase 200 metros acima de Caeté, adentrase àquela vila, não sem antes transpor uma sombria capoeira, o que magnifica a surpresa de seu irrompimento súbito. Construções antigas e recentes se alternam, pelas ruas declivosas deste sítio nada propício à edificação. Poucas pessoas são vistas nas ruas. Talvez por isso a presença de "gente de fora" não passe despercebida por seus moradores. Bem no alto da vila a velha igreja subordina-se apenas ao céu.

Prosseguindo além do povoado, por qualquer caminho, retoma-se às paisagens mais típicas do distrito, onde os traços da apropriação do espaço são comparativamente mais efêmeros. Pastos, gado, capoeiras...

Esta é uma paisagem multifacetada, percebida por cada observador de forma muito particular. A representação clássica do matuto que a vê como paisagem utilitária, suporte de sua subsistência, bem como o olhar pictórico dos forasteiros bem instruídos, fascinados pela asperez da vida rústica, ainda que não completamente extintas, cedeu lugar a combinações mais complexas, como não poderia deixar de ser, neste ambiente apropriado por pessoas de origens e formações muito diversas. 


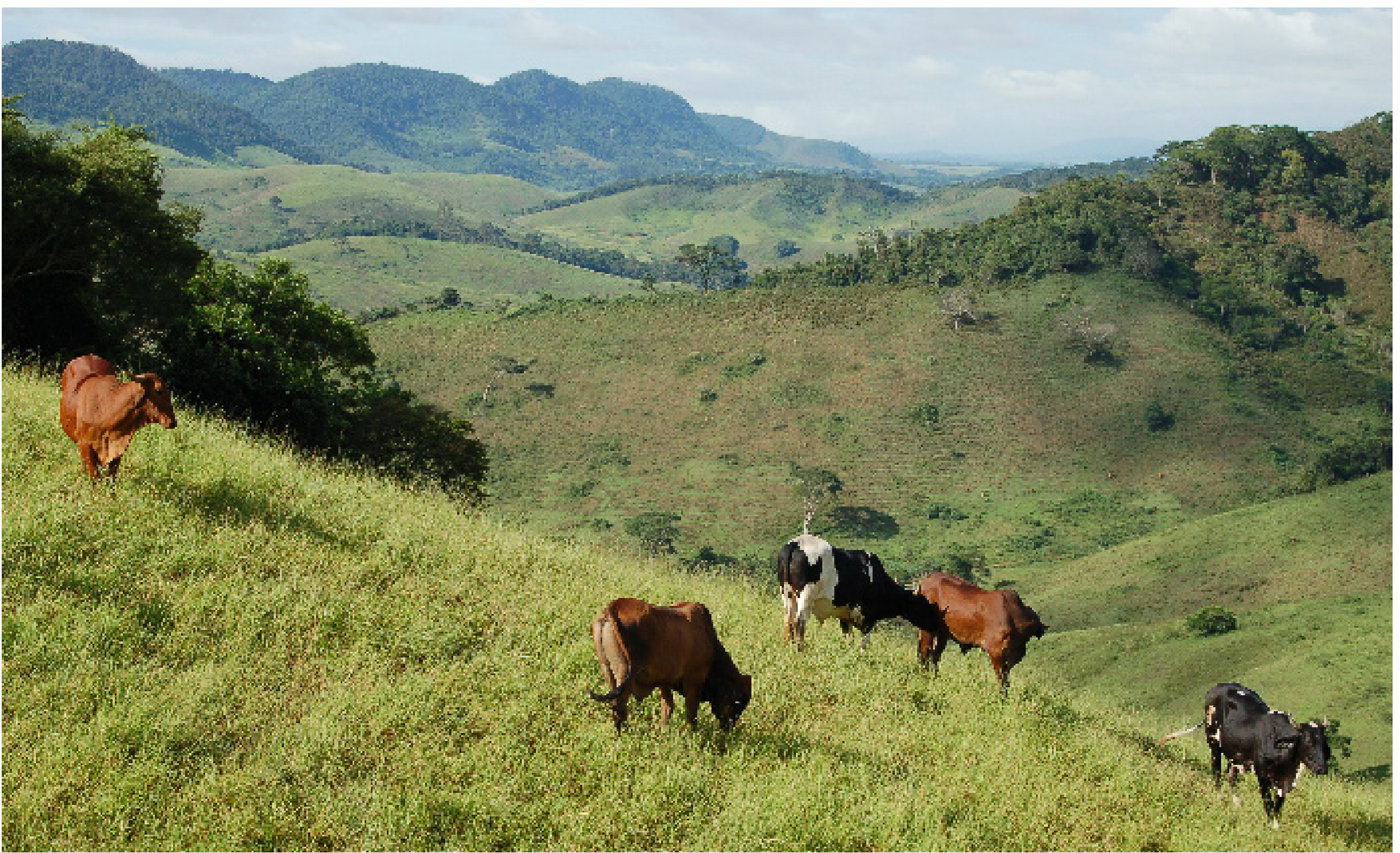

Antes da F. Vargem Alegre, acessando o alto da serra pela estrada pública, vê-se ao fundo a Serra do Mina, na porção sul do distrito. Crédito: Autor 


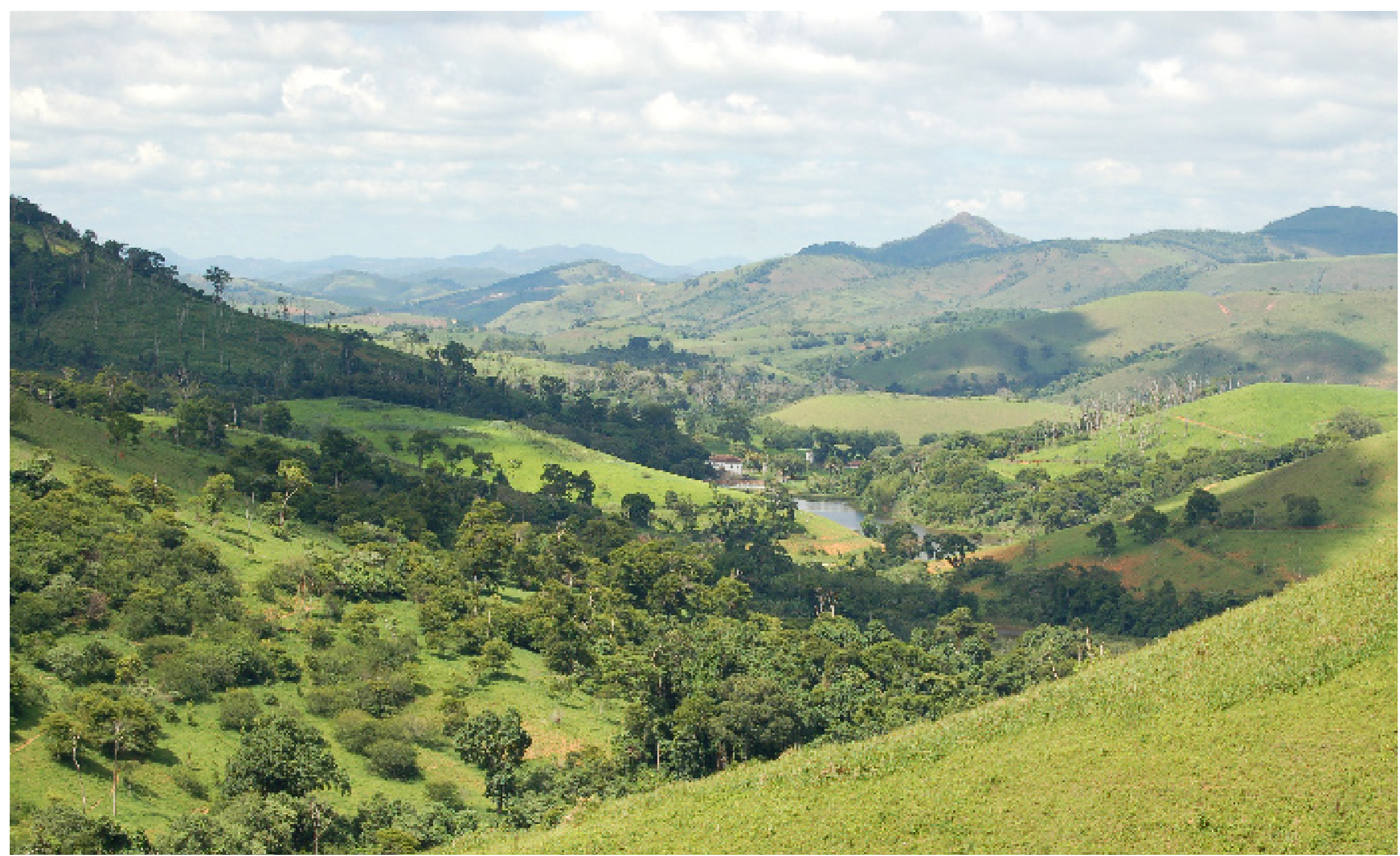

Vista a partir da estrada que liga as fazendas Engenho Velho e S. Lourenço. Em destaque a F. Boa Vista, no vale do córrego Caeté. Crédito: Autor 


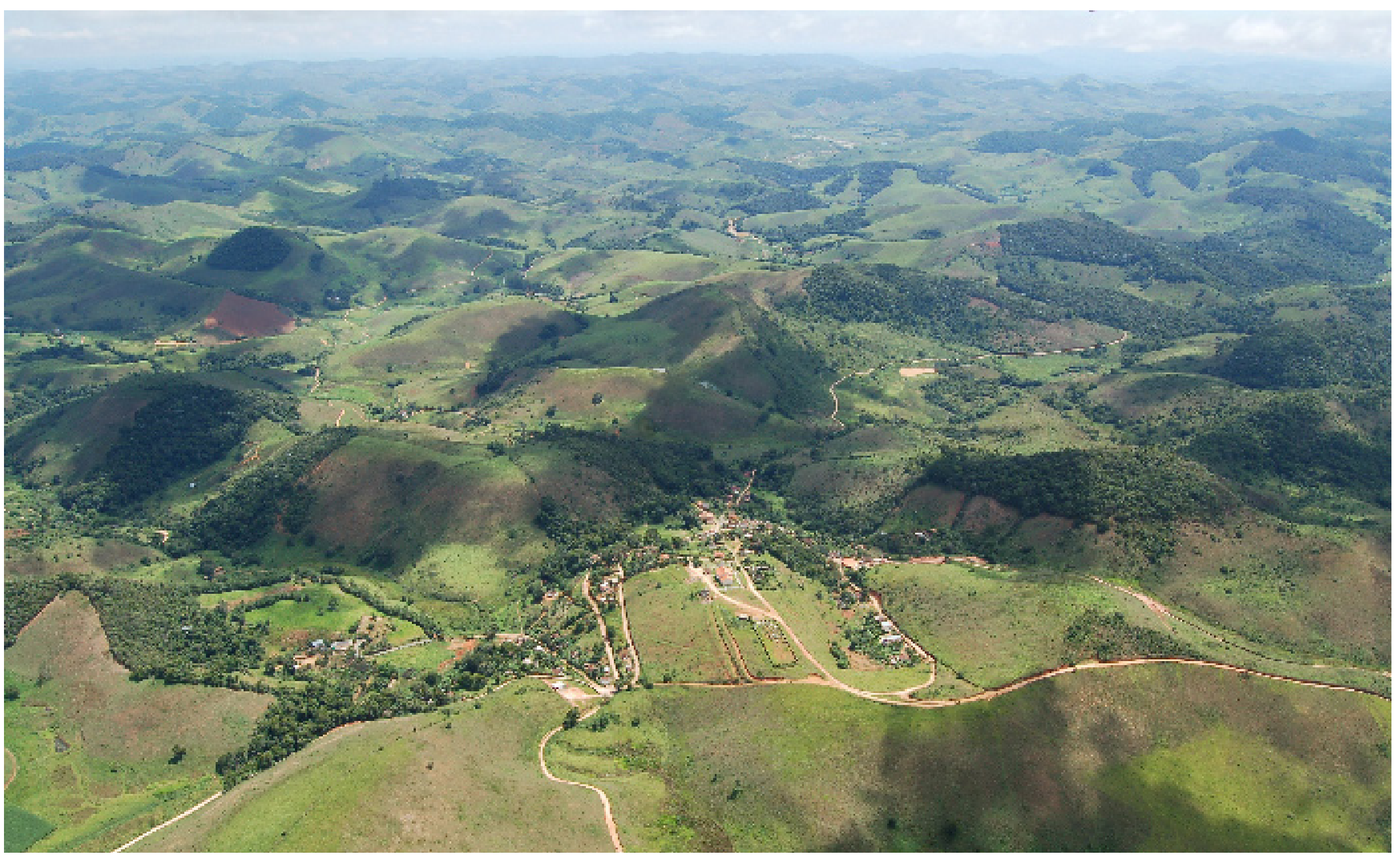

Vista aérea, sentido sul-norte: em primeiro plano a vila de Sarandira. Ao redor, as várias fazendas se espalham pelo mar de morros. Crédito: Autor 


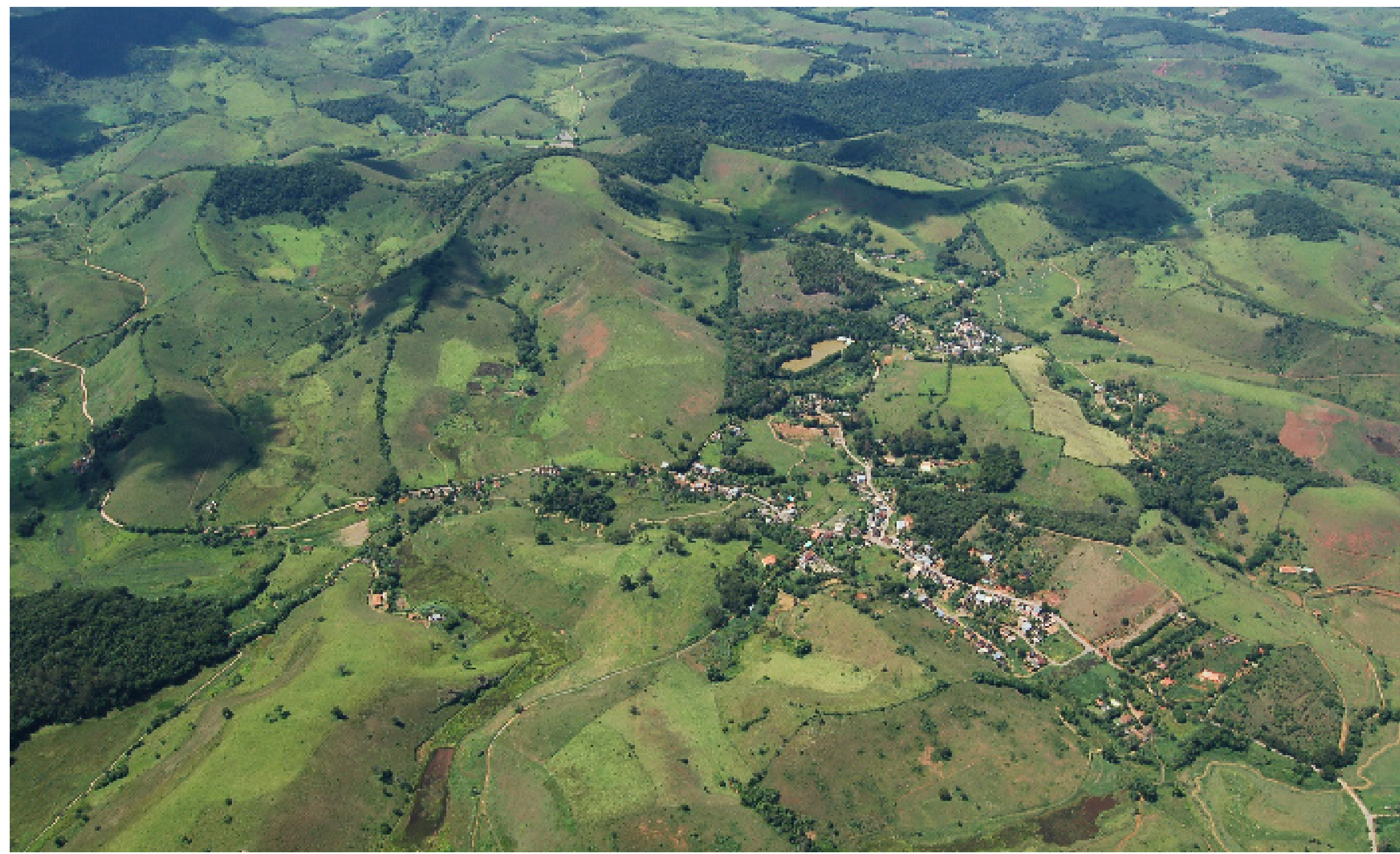

Vista aérea, sentido norte-sul: O povoado de Caeté, junto à via que liga Juiz de Fora, à direita, e a vila de Sarandira, à esquerda. 
Num esforço de síntese, podem ser identificadas duas unidades fisiográficas principais contidas pelo distrito de Sarandira. Um sobrevôo, ou mesmo uma avaliação por terra a partir de seus cumes mais elevados, permite identificar que estas mesmas características mais gerais estendem-se a perder de vista.

Neste aspecto, como em muitos outros, a topografia tem papel decisivo. É ela que, através de suas restrições, pauta as atividades ali desenpenhadas. Condicionando as formas de intervenção no ambiente, tem influência profunda no desenho da paisagem, esta que, não é demais assinalar novamente, deriva das interações recíprocas da sociedade com a natureza.

Os dois setores fisiográficos em questão são representados pelo conjunto formado pelos fundos de vales e meias-encostas, e acima destas. Esse tapete de planos côncavos e convexos, no qual se alinham suas redes de drenagem, não se destaca apenas por sua plasticidade. Com influências sobre a facilidade de acesso, qualidade do solo agrícola e sua possibilidade de cultivo, disponibilidade de água, abrigo, entre outros fatores, ele conformará ambientes distintos no que se refere ao uso antrópico deste espaço e à sua percepção. Com isso aqueles primeiros terrenos são muito utilizados, e os demais recebem pouco ou nenhum uso.

Conseqüentemente, essas características mais gerais determinaram a existência de unidades paisagísticas mais específicas, a saber:

Unidade vilarejo: Ambientes de trabalho e convívio, fortemente antropizados, são integrados pelo povoado de Caeté e pela vila de Sarandira, mas havendo entre ambos diferenças consideráveis.

O primeiro é comparativamente um espaço mais confinado, pelo arruamento 
tortuoso que se espraia sobre um mesmo plano. Significativamente mais barulhento, ao som das construções, crianças, carros e bares.

Já o segundo é um ambiente nostálgico e mais intimista, com menor número de atividades e concentração de pessoas às ruas. É caracterizado por ser um espaço semi-aberto, já que o possível confinamento da visão pelas vias é extrapolado por conta de sua disposição em diferentes níveis.

Unidade núcleos das propriedades rurais: Sede das empresas rurais. Reúne a totalidade das áreas de baixada e meia-encostas, onde situam-se as instalações que as compõem, bem como as áreas dedicadas aos cultivos e pastagens mais nobres.

Espaço semi-aberto e voltado à produção, abrigando a maior parte do patrimônio arquitetônico ainda presente no distrito, além de nascentes e, em algumas raras situações, matas higrófitas.

Unidade pastos (invernadas): Situadas nas porções mais elevadas e declivosas do terreno, onde os campos são extensos e o rebanho, em especial os machos e as vacas falhadas, destinados ao corte, permanece por longos períodos sem receber trato. Também por isso, são áreas mais raramente acessadas, recebendo pouca manutenção. Como as estradas internas das propriedades não costumam ligar-se a essas áreas, o acesso se dá em meio às gramíneas, normalmente a cavalo. São espaços mais silenciosos e amplos, que possibilitam o descortinar de longas vistas.

Ainda que de baixa retenção, por serem ocupadas principalmente por vegetação rasteira, devido às suas grandes dimensões são áreas importantes para a recarga de mananciais. 
Unidade florestal: Essas áreas compartilham um território contíguo às pastagens. Dada a sua variedade de dimensões, quando são muito pequenas constituem mais apropriadamente elementos da paisagem, e não segmentos de paisagem.

São espaços fechados, silenciosos, mais frios e úmidos. Entre as demais unidades, a mata é a que simboliza as maiores contradições a respeito da leitura que se faz da região por diferentes indivíduos: para muitos é tida como recurso a ser explorado, seja por sua madeira, lenha ou caça, já outros a consideram patrimônio inestimável a ser preservado. Uns a admiram fascinados, outros a temem, havendo ainda quem parece ser completamente indiferente à sua presença.

São ainda locais estratégicos para a recarga dos mananciais e para a conservação dos hábitats de vida selvagem.

A depender da escala de cada abordagem, essas quatro unidades descritas tanto podem conformar uma única paisagem, a do distrito de Sarandira, como podem se decompor em uma infinidade de sub-paisagens, igualmente ricas, como são constantes em seus muitos rincões, que abrigam árvores, matas, quedas-dágua, construções ou ruínas, muitas vezes de grande valor pictórico. Em qualquer escala, essas paisagens derivam das formas de uso do solo, que vêm sendo redefinidas ao longo dos anos.

\section{EVOLUÇÃO DO USO DO SOLO}
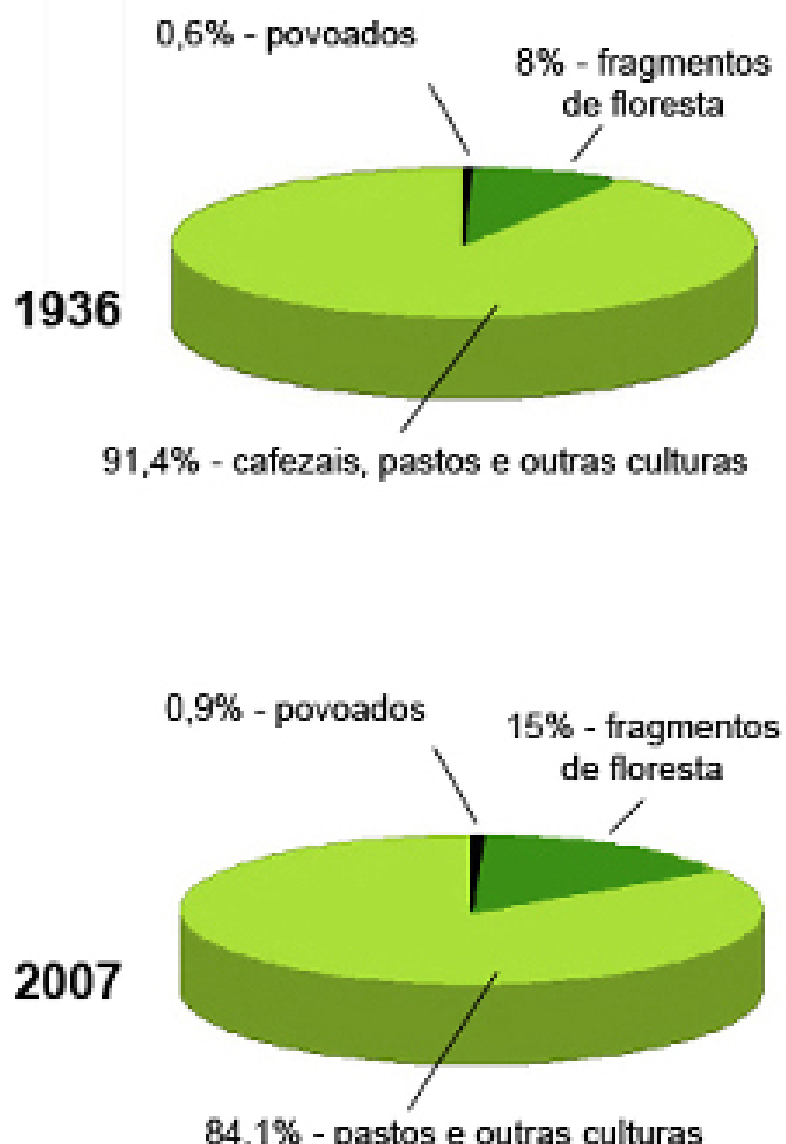

Crédito: Autor. Fontes: Comissão Geográphica Geológica de Minas Geraes; Embrapa - Brasil Visto do Espaço. 


\section{LEGENDA}

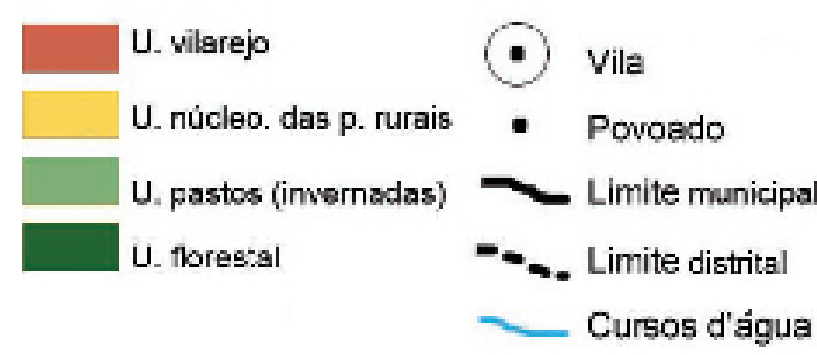

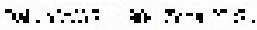

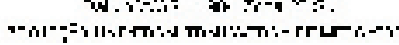

I: 0: 0:0

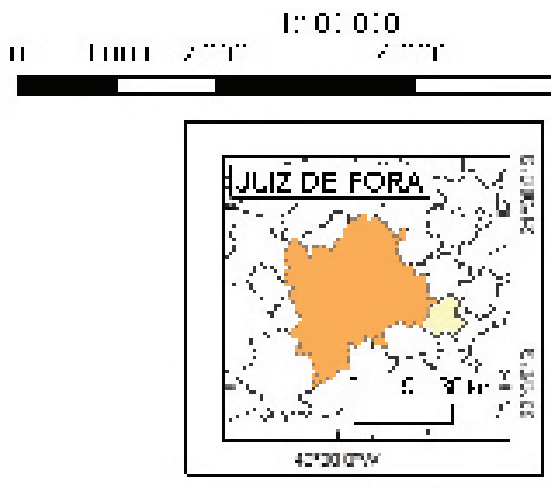

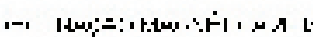

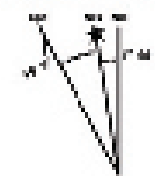

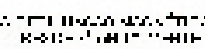

1 2 r. - - w :

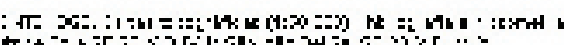

itine

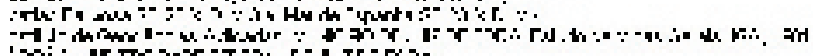

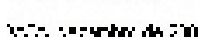

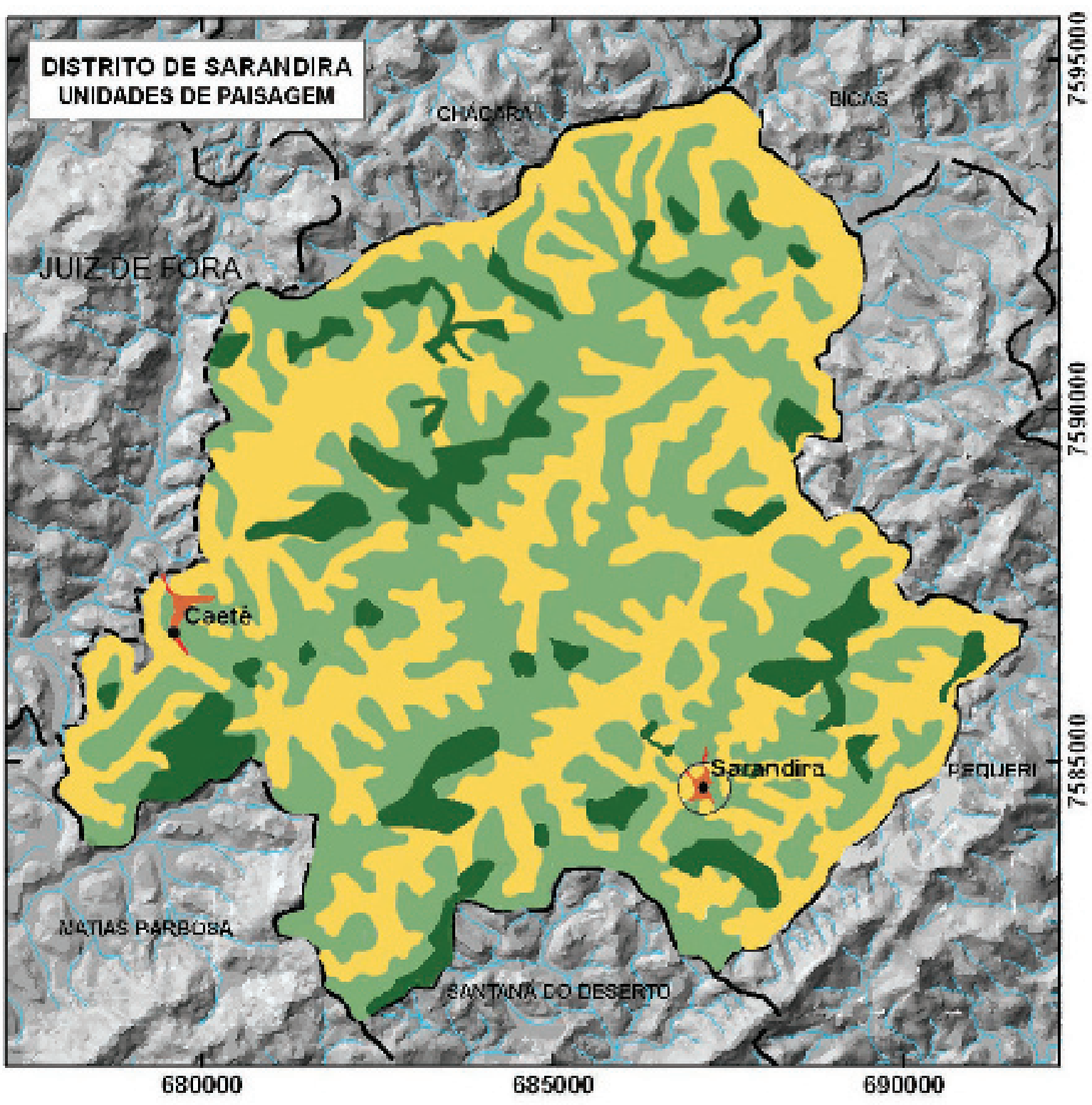




\section{CAPÍTULO}

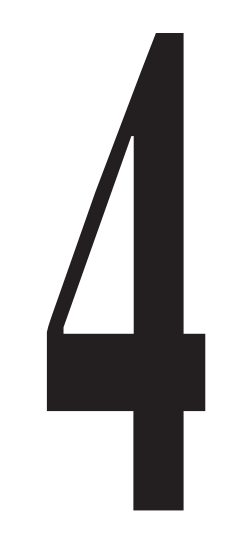




\section{4 - Proteção da paisagem e do ambiente: restrições e oportunidades}

Como visto no capítulo anterior, o distrito de Sarandira é detentor de um rico patrimônio paisagístico e ambiental. O desenvolvimento de estratégias voltadas à sua proteção, clareando as restrições e oportunidades daí decorrentes, passa pelo conhecimento dos instrumentos legais disponíveis, seus mecanismos e suas formas de aplicação. Ainda que seja função da municipalidade ordenar o desenvolvimento urbano da região, é necessário buscar soluções abrangentes para todo o distrito de Sarandira, e não apenas seus dois povoados.

Assim, este capítulo é voltado à constituição de um breve panorama das áreas protegidas no Brasil e suas diversas modalidades, apresentando a instituição do Sistema Nacional de Unidades de Conservação (SNUC) como avanço significativo nesta questão, e duas das suas categorias de manejo, APAs e RPPNs, destacadas por se mostrarem mais indicadas para o enfrentamento dos desafios que se colocam àquela zona rural. Estas exposições são necessárias para a problematização da proposta de criação de uma Unidade de Conservação local, levantada ao final do capítulo. 


\section{1 Áreas protegidas no Brasil}

Como foi visto no capítulo 1, ao mais distante reconhecimento de lugares e artefatos dotados de valor excepcional seguiram-se medidas voltadas à sua proteção. No Brasil, a instituição de áreas destinadas ao abrigo desse patrimônio vem se valendo, ao menos na teoria, de dispositivos variados.

Segundo o Ministério do Meio Ambiente, (Brasil - MMA, 2007), são denominadas áreas protegidas:

áreas de terra e/ou mar especialmente dedicadas à proteção e manutenção da diversidade biológica, e de seus recursos naturais e culturais associados, manejadas por meio de instrumentos legais ou outros meios efetivos.

O Plano Nacional de Áreas Protegidas, o PNAP (Brasil - MMA, 2006), as conceitua como:

Áreas definidas geograficamente, cuja regulamentação e/ou administração promovam a proteção, conservação, recuperação e o uso sustentável da biodiversidade, bem como a repartição justa e equiitativa dos benefícios, contemplando de forma prioritária as Unidades de Conservação, as Terras Indígenas e os Territórios Quilombolas. 
59 O Sistema de Reservas da Biosfera é um instrumento de proteção do patrimônio ambiental, que teve no Brasil um destaque maior entre as demais Áreas de Reconhecimento Internacional por sua inclusão no texto do SNUC. Segundo COSTA (2007) estas áreas priorizam "a conservação da natureza e de sua biodiversidade, o desenvolvimento social sustentado das populações que vivem na Reserva, com ênfase para as comunidades tradicionais, e o aprofundamento da educação ambiental e do conhecimento científico."

${ }^{60}$ A Convenção sobre Zonas Úmidas, assinada em Ramsar, Iran, foi um tratado internacional voltado à criação de uma rede de cooperação para o desenvolvimento sustentável das regiõ̃es úmidas do globo: ambientes continentais e costeiros, como áreas de mangue, lagunas, planícies inundáveis, etc. De suas ações decorrem 157 sítios preservados, oito deles no Brasil.

61 Os Sítios do Patrimônio Mundial Natural (UNESCO, 2007) resultam da Conferência Geral da UNESCO realizada em 1972. Hoje essas áreas protegidas, presentes em 142 países, já somam 851 , sendo que destas, 660 são voltadas ao patrimônio cultural, 166 ao patrimônio natural e 25 voltadas à conservação de ambos.

62 COSTA (2007) cita como as mais notórias áreas naturais tombadas do Brasil a pedra do Pão-de-Açúcar e o pico do Corcovado, no Rio de Janeiro. Também importantes remanescentes de Mata Atlântica, nas regiões sul e sudeste do país. Ainda segundo este autor, estas áreas
Essas porções do território nacional, portanto, englobam não apenas as Unidades de Conservação da Natureza (UCs), que são o exemplo mais emblemático dessas áreas, subordinadas à Lei do SNUC de 2000, mas também Reservas Legais (RLs) e Áreas de Preservação Permanente (APPs) presentes no Código Florestal de 1965, Terras Indígenas (TIs), definidas pelo Estatuto do Índio de 1973, os Territórios Quilombolas, mediante o Decreto PNAP de 2006 e, por fim, as Áreas de Reconhecimento Internacional (ARIs), oriundas de encontros internacionais do início dos anos 70 como o programa Man and the Biosphere (MAB), a convenção sobre Zonas Úmidas e a Convenção para a Proteção do Patrimônio Mundial, Cultural e Natural, a partir dos quais foram definidas, respectivamente, as Reservas da Biosfera ${ }^{59}$, os Sítios Ramsar ${ }^{60}$ e os Sítios do Patrimônio Mundial Natural ${ }^{61}$.

Há ainda outros instrumentos voltados a este fim, com destaque para as Áreas Naturais Tombadas ${ }^{62}$. Segundo COSTA (2007):

Fora do setor estrito de proteção da natureza, que ocorre através dos sistemas oficiais encarregados da gestão dos recursos naturais, existem no Brasil várias outras categorias de áreas protegidas interessantes de se conhecer. A mais antiga é a área natural de interesse à cultura e de proteção das paisagens notáveis. Essas áreas, no Brasil, são chamadas de áreas tombadas (...) "Tombamento" ou área natural tombada tem, portanto, o sentido de uma área que, por suas características excepcionais, está sujeita a restrições de uso que a protegem. 
A atual variedade desses instrumentos, aos quais se soma a recente e ainda pouco conhecida Lei da Mata Atlântica ${ }^{63}$, é sem dúvida um reflexo positivo da ascensão das questões ambientais em nosso cotidiano, mas dela também decorrem alguns problemas, como observa, entre outros, MEDEIROS (2006, p. 42): "a proliferação desses instrumentos (...) teve como uma das consequiências a criação de um sistema pouco articulado e redundante." Ainda segundo aquele autor (2006, p. 59):

Ao consolidar, mesmo que não intencionalmente, as Unidades de Conservação como tipologia dotada de maior visibilidade e expressão, e dotá-la de instrumentos mais concretos de gestão, as outras tipologias que ainda continuaram a existir mesmo após a criação do SNUC - as APPs, as RLs, as TIs e as ARIs - continuaram relegadas aos mesmos problemas históricos de gestão e, mais grave, não dispondo de instrumentos de integração e articulação com as ações previstas para as Unidades de Conservação.

Essa questão é uma vaga amostra de uma infinidade de problemas ligados à quase totalidade dessas áreas no país. Sua implementação e gestão vem esbarrando, sobremaneira, em conflitos fundiários, extração ilegal de recursos naturais, falta de recursos humanos e materiais em quantidade e qualidade necessários para sua gestão, sendo essas áreas, por tudo isso, freqüentemente taxadas como "ficções jurídicas" ou "parques de papel”. Problemas crônicos que expõem a fragilidade da efetiva salvaguarda deste patrimônio nacional. são protegidas por serem "símbolos, paisagens notáveis do País e, também, pelo entendimento de que a natureza é a base da cultura de um povo."Justificativas que remetem à questão do patrimônio, que está na raiz dos tombamentos.

63 Lei $\mathrm{n}^{\circ} 11.428$ de dezembro de 2006, que estabelece dispositivos para a proteção eutilização do Bioma Mata Atlântica, destacando (artigo $6^{\circ}$ parágrafo único) a observância: "dos princípios da função socioambiental da propriedade, da eqüidade intergeracional, da prevenção, da precaução, do usuário-pagador, da transparência das informações e atos, da gestão democrática, da celeridade procedimental, da gratuidade dos serviços administrativos prestados ao pequeno produtor rural e às populações tradicionais e do respeito ao direito de propriedade. 


\subsection{Código Florestal}

De grande rebatimento no âmbito da zona rural tratada nesta pesquisa, as questões que envolvem o Código Florestal e seus mecanismos, as Reservas Legais e as APPs, merecem ser destacados.

O Código Florestal, datado de 1934, foi o primeiro importante instrumento de proteção às formações florestais no país. No contexto de sua criação, estão a pujante modernização e crescimento das cidades e a intrusão das questões ambientais na alçada das responsabilidades governamentais, através de pressões dos então vanguardistas movimentos conservacionistas. De acordo com MEDEIROS (2006, p. 46, 50):

A consolidação das aspirações conservacionistas ficou registrada na segunda constituição republicana, de 1934. Nela, pela primeira vez, a proteção da natureza figurava como um princípio fundamental para o qual deveriam concorrer a União e os Estados. Em seu contexto (Capítulo I, artigo 10), ficou definida como responsabilidade da União "proteger belezas naturais e monumentos de valor histórico e artístico." (...) Ao tratar a questão da proteção da natureza como responsabilidade da União e dos Estados, mesmo que de maneira resumida e pouco precisa, a Constituição de 1934 outorgava à natureza um novo valor, isto é, ela passava a ser considerada patrimônio nacional admirável a ser preservado. Com isso sua proteção adquire novo sentido e status, consistindo em tarefa ou dever a ser cumprido e fiscalizado pelo poder público. (...) É neste 
cenário que os principais dispositivos legais de proteção da natureza, que levaram à criação e consolidação das primeiras áreas protegidas, são criados contemporaneamente no Brasil.

Em 1965 o Código Florestal foi reeditado ${ }^{64}$, seguindo sem grandes mudanças as propostas de seu antecessor. Ele passou a incorporar as tipologias Parque Nacional, Floresta Nacional, APP e Reserva Legal. Destas, continuam sob sua alçada as duas últimas, orientadas não apenas à proteção das formações florestais, mas também dos solos e dos recursos hídricos.

Assim, pela Lei 4771/1965 65 , que instituiu o chamado "novo" Código Florestal, ainda em vigor, as APPs são as áreas dispostas:

1) ao longo dos rios ou de qualquer curso d'água; 2) ao redor das lagoas, lagos ou reservatórios d'água; 3) nas nascentes e "olhos d'água" num raio de 50m de largura; 4) no topo dos morros, montes, montanhas e serras; 5) nas encostas ou parte destas, com declividade superior a $100 \%$ na linha de maior declive; 6) nas restingas, como fixadoras de dunas ou estabilizadoras de mangues; 7) nas bordas dos tabuleiros ou chapadas, a partir da linha de ruptura do relevo, em faixa nunca inferior a 100m em projeções horizontais; 8) em altitude superior a $1800 \mathrm{~m}$, qualquer que seja a vegetação.
64 Lei 4771/1965

65 Aqui apresentada em resumo, extraída de MEDEIROS (2006, p. 48).

Já as Reservas Legais correspondem à respectivamente: 
1) $80 \%$ da propriedade rural na Amazônia Legal; 2) $35 \%$ na propriedade rural em área de cerrado localizada na Amazônia Legal; 3) $20 \%$ na propriedade rural em área de floresta ou vegetação nativa nas demais regiões; 4) 20\% na propriedade rural em área de campos gerais em qualquer região.

Com relação à sua aplicabilidade, a rigor, o atual Código Florestal não faz distinção entre áreas urbanas e rurais, mas como seu cumprimento nas cidades é completamente negligenciado acabou recaindo apenas sobre o campo. E é a partir do campo, particularmente dos latifúndios, que ecoa a grande resistência ao cumprimento desta legislação. Propostas de alteração dos dispositivos das Reservas Legais e APPs são freqüentemente aventadas por pressão da bancada ruralista nacional. Conforme MEDEIROS (2006, p. 59), o debate sobre a revisão do Código Florestal se arrasta lentamente no Congresso Nacional devido "às disputas cada vez mais acirradas entre os diferentes grupos que atuam ou têm interesse nesta área no Brasil."

Novas reformulações do Código Florestal são previstas para um futuro próximo. 


\subsection{SNUC: Sistema Nacional de Unidades de Conservação}

No Brasil, a salvaguarda de seus bens ambientais e paisagísticos alcançou um novo patamar com a criação do Sistema Nacional de Unidades de Conservação, (SNUC) e as diversas categorias de Unidades de Conservação (UCs) por ele compreendidas.

Assim são definidas as UCs pelo Ministério do Meio Ambiente (Brasil, 2007):

As unidades de conservação (UC), um tipo especial de área protegida, são espaços territoriais (incluindo seus recursos ambientais e as águas jurisdicionais) com características naturais relevantes, legalmente instituídos pelo Poder Público, com objetivos de conservação e de limites definidos, sob regime especial de administração, às quais se aplicam garantias adequadas de proteção.

Essas diferentes categorias de manejo que compõem o SNUC, como será detalhado mais à frente, variam em seus objetivos, cada uma delas procurando dar conta das especificidades encontradas nas variadas porções do território nacional, as quais se pretende conservar. Assim, diversos são os níveis de proteção contemplados, variando desde categorias de áreas limitadas à conservação da vida selvagem e à investigação científica, até aquelas voltadas ao desenvolvimento sustentável das comunidades que delas dependem, permitindo assim o uso de seus recursos naturais. 
66 Primeiro e mais importante evento de abrangênciainternacional a discutir a conservação ambiental, a Conferência das Nações Unidas sobre o Meio Ambiente Humano foi organizada pela ONU no dia 05 de junho de 1972 (data em que se comemora a partir de então o Dia Mundial do Meio Ambiente), reunindo representantes de 113 países. Este encontro firmou-se como marco histórico na definição da política ambiental global.
Remetendo brevemente aos antecedentes do SNUC, destacam-se a criação do Código Florestal em 1934, que instituía entre outros a figura do Parque Nacional. Décadas depois, nos anos de 1970, outro avanço significativo, com a definição de muitas áreas preservadas na Amazônia através da Política Brasileira de Parques Nacionais e Reservas Equivalentes (BRITO, 2000, p. 85-87).

Esses instrumentos, no entanto, estavam muito longe de assegurar o cumprimento de seu objetivo maior, o de preservação da natureza. Ainda segundo BRITO (idem, p. 58), antes dos anos 70 os mecanismos de proteção ambiental do país eram bastante frágeis:

\begin{abstract}
Até meados da década de setenta, o Brasil não possuía uma estratégia nacional global para selecionar e planejar as unidades de conservação, fosse por meio de legislação básica ou por declaração política. As unidades de conservação, até então, justificavam-se pelas belezas cênicas que possuíam. A proteção dos ecossistemas e de espécies ameaçadas, do ponto de vista conceitual e metodológico, era ainda precária.
\end{abstract}

A criação da Secretaria Especial do Meio Ambiente (Sema) em 1973, no contexto do efervescente movimento internacional conservacionista e da Conferência de Estocolmo ${ }^{66}$, de 1972, também merece destaque. Período em que foram criadas diversas Estações Ecológicas e Áreas de Proteção Ambiental. Em 1979, influenciado pelas diretrizes propostas pela União Internacional para a Conservação da Natureza (UICN) sobre o estabelecimento de um sistema 
de unidades de conservação um ano antes, classificação esta que, segundo COSTA (2007), é a mais amplamente aceita e consolidada internacionalmente, o Instituto Brasileiro de Desenvolvimento Florestal (IBDF) propõe a I Etapa do Plano do Sistema de Unidades de Conservação para o Brasil. De acordo com BRITO (idem, p. 61):

Pode-se dizer que foi a partir dessa data que ficaram explícitas oficialmente as bases conceituais nas quais o poder público federal já vinha e continuaria se apoiando, para o estabelecimento e gestão de suas unidades de conservação.

Em 1989 é criado o Instituto Brasileiro do Meio Ambiente e dos Recursos Naturais Renováveis (IBAMA) que, entre outras atribuições, buscava unificar a política ambiental nacional. Naquele ano também foi elaborada uma proposta de Sistema Nacional de Unidades de Conservação (SNUC) voltada, conforme BRITO (idem, p. 67), a "sistematizar conceitos, objetivos e tipos dessas unidades", porém ainda orientada basicamente à conservação da biodiversidade, em detrimento dos aspectos culturais, que só passariam a receber maior atenção em futuras formulações.

Baseando-se nesta proposta, decorridos três anos e sob efeito da Rio-92 ${ }^{67}$, é encaminhado ao Congresso Nacional o projeto de lei que efetivamente cria o SNUC. Sua aprovação ocorre somente em 1999, tornando-se lei no ano $2000^{68}$.
${ }^{67}$ Conferência das Nações Unidas para o Meio Ambiente e o Desenvolvimento (CNUMAD), realizada no Rio de Janeiro em junho de 1992.

68 Lei 9985/2000, que institui o SNUC estabelecendo critérios e normas para a criação implantação e gestão das UCs brasileiras. 
De acordo com o Ministério do Meio Ambiente (Brasil, 2007) O SNUC, constituído por UCs federais, estaduais e municipais, tem como objetivos:

I - contribuir para a manutenção da diversidade biológica e dos recursos genéticos no território nacional e nas águas jurisdicionais;

II - proteger as espécies ameaçadas de extinção no âmbito regional e nacional;

III - contribuir para a preservação e a restauração da diversidade de ecossistemas naturais;

IV - promover o desenvolvimento sustentável a partir dos recursos naturais;

V - promover a utilização dos princípios e práticas de conservação da natureza no processo de desenvolvimento;

VI - proteger paisagens naturais e pouco alteradas de notável beleza cênica;

VII - proteger as características relevantes de natureza geológica, geomorfológica, espeleológica, arqueológica, paleontológica e cultural;

VIII - proteger e recuperar recursos hídricos e edáficos;

IX - recuperar ou restaurar ecossistemas degradados;

$\mathrm{X}$ - proporcionar meios e incentivos para atividades de pesquisa científica, estudos e monitoramento ambiental;

XI - valorizar econômica e socialmente a diversidade biológica;

XII - favorecer condições e promover a educação e interpretação 
ambiental, a recreação em contato com a natureza e o turismo ecológico;

XIII - proteger os recursos naturais necessários à subsistência de populações tradicionais, respeitando e valorizando seu conhecimento e sua cultura e promovendo-as social e economicamente.

O SNUC ainda divide-se em duas categorias: Unidades de Proteção Integral e Unidades de Uso Sustentável. As do primeiro grupo têm como objetivo precípuo a preservação da natureza, e são representadas pelas Estações Ecológicas, Reservas Biológicas, Parques Nacionais, Monumentos Naturais e Refúgios de Vida Silvestre. As do segundo grupo são voltadas à compatibilização entre a conservação da natureza e o uso sustentável de parte de seus recursos naturais, sendo formadas pelas Áreas de Proteção Ambiental, Áreas de Relevante Interesse Ecológico, Florestas Nacionais, Reservas Extrativistas, Reservas de Fauna, Reservas de Desenvolvimento Sustentável e as Reservas Particulares do Patrimônio Natural.

O SNUC representou avanços significativos na instituição de áreas protegidas do país, apesar dos já citados problemas de gestão dessas unidades. Entre os fatores positivos destaca-se a abordagem integradora e sistêmica entre as suas categorias de manejo, que pode ser exemplificada pela proposição de mosaicos de UCs ou pela criação de corredores ecológicos entre estas. Para MEDEIROS (2006, p. 57): 
vez parte das áreas protegidas prevista pela Legislação brasileira até então, como abriu espaço para que novas categorias fossem criadas ou incorporadas a partir de experiências originais desenvolvidas no país.

Cada vez mais, novas UCs são criadas no território nacional. Entre estas, duas se destacam pela provável maior aderência às peculiaridades do Distrito de Sarandira: APAs e RPPNs. 


\subsection{APAs: Áreas de Proteção Ambiental}

No início da década de 1980, a Secretaria Especial de Meio Ambiente (SEMA) alcançou a aprovação de uma lei ${ }^{69}$ referente à instituição de uma nova categoria de área protegida, a Área de Proteção Ambiental (APA).

Pelo atual SNUC, que passou a abrigar entre suas Unidades de Uso Sustentável as APAs $^{70}$, estas são assim definidas:

A Área de Proteção Ambiental é uma área em geral extensa, com um certo grau de ocupação humana, dotada de atributos abióticos, bióticos, estéticos ou culturais especialmente importantes para a qualidade de vida e o bem-estar das populações humanas, e tem como objetivos básicos proteger a diversidade biológica, disciplinar o processo de ocupação e assegurar a sustentabilidade do uso dos recursos naturais.

$\S 1^{\circ}$ A Área de Proteção Ambiental é constituída por terras públicas ou privadas.

$\S 2^{\circ}$ Respeitados os limites constitucionais, podem ser estabelecidas normas e restrições para a utilização de uma propriedade privada localizada em uma Área de Proteção Ambiental.

$\S 3^{\circ}$ As condições para a realização de pesquisa científica e visitação pública nas áreas sob domínio público serão estabelecidas pelo órgão gestor da unidade.

$\S 4^{\circ}$ Nas áreas sob propriedade privada, cabe ao proprietário
${ }^{69}$ Lei 6902/1981, através da qual ficava permitido ao Poder Executivo declarar certas áreas como prioritárias à conservação ambiental e, ciente dos direitos de propriedade, limitava ou proibia: a) - a implantação e o funcionamento de indústrias potencialmente poluidoras, capazes de afetar mananciais de água;

b) - a realização de obras de terraplenagem e a abertura de canais, quando essas iniciativas importarem em sensível alteração das condições ecológicas locais;

c) - o exercício de atividades capazes de provocar uma acelerada erosão das terras e/ou um acentuado assoreamento das coleções hídricas;

d) - o exercício de atividades que ameacem extinguir na área protegida as espécies raras da biota regional.

${ }^{70}$ Lei 9985/2000: Art. 15. 
71 Segundo COSTA (2007) sua origem, mais especificamente, figura na dos Parques Naturais europeus, relacionados ao modelo proposto pelo modelo da Reserva da Biosfera do programa $\mathrm{MAB}$, da Unesco, que já vinha sendo implantado em diversos países antes do Brasil. estabelecer as condições para pesquisa e visitação pelo público, observadas as exigências e restrições legais.

$\S 5^{\circ}$ A Área de Proteção Ambiental disporá de um Conselho presidido pelo órgão responsável por sua administração e constituído por representantes dos órgãos públicos, de organizações da sociedade civil e da população residente, conforme se dispuser no regulamento desta Lei.

Sua origem, conforme MORAES (2000, p.75), remete às áreas protegidas da Europa, que tiveram como orientação "a paisagem e o equilíbrio natural". No Brasil, àqueles objetivos, ainda segundo aquela autora (idem, idem), somou-se a preocupação de contornar o problema dos altos custos das desapropriações para a proteção ambiental" 71 .

É justamente neste aspecto que reside uma de suas maiores particularidades. Essas unidades prescindem da desapropriação das terras por elas contidas, podendo ser declaradas tanto em áreas públicas como em propriedades privadas. Neste sentido afirma COSTA (2007):

(...) as APAs, que prescindem de desapropriação, não propriamente resolvem a questão, que é crônica, mas dão abertura a uma forma alternativa e complementar de proteção da natureza, servindo perfeitamente para serem usadas em diversas situações de grande importância. 
Congregando uma grande variedade de ambientes, de zonas rurais a cidades, passando pelo abrigo de outras UCs mais restritivas em termos de utilização, para as quais atua como zona tampão, este instrumento, bastante flexível em suas determinações, pode ser consideradoumindutor do desenvolvimento sustentável. As atividades econômicas em seu interior são permitidas, observando-se os limites estabelecidos pelo seu órgão gestor. Para tanto, sua principal ferramenta é o Zoneamento Ambiental, um planejamento de uso do solo que pode definir áreas prioritárias para a preservação da biodiversidade, outras voltadas ao uso sustentável dos recursos naturais, áreas voltadas à expansão urbana controlada, áreas de interesse histórico-cultural, etc. 


\subsection{RPPNs: Reservas Particulares do Patrimônio Natural}

${ }^{72}$ Decreto n $^{\circ} 1.922$, de 5 de junho de 1996.

73 Artigo 21 da Lei 9985/2000.
O estabelecimento de áreas particulares protegidas no Brasil já era previsto no Código Florestal de 1934, através das então chamadas "Florestas Protetoras". Com o passar dos anos, os mecanismos que permitiam aos proprietários de terras a decretação de reservas particulares de proteção ambiental, mudaram de nome. Assim foi quando da instituição do novo Código Florestal em 1965 e, posteriormente, mediante a edição de portarias do IBAMA nas décadas de $1970 \mathrm{e}$ 1980. Outros marcos importantes foram decretos trazendo uma regulamentação mais detalhada desse tipo de iniciativa, datados dos anos 90.

Assim, no ano de 1996 foram criadas as Reservas Particulares do Patrimônio Natural (RPPNs) ${ }^{72}$, tipologia que passou a integrar o rol das Unidades de Uso Sustentável do SNUC $^{73}$, em 2000, sendo assim definida:

\footnotetext{
A Reserva Particular do Patrimônio Natural é uma área privada, gravada com perpetuidade, com o objetivo de conservar a diversidade biológica.

$\S 1^{\circ}$ O gravame de que trata este artigo constará de termo de compromisso assinado perante o órgão ambiental, que verificará a existência de interesse público, e será averbado à margem da inscrição no Registro Público de Imóveis.

$\S 2^{\circ}$ Só poderá ser permitida, na Reserva Particular do Patrimônio Natural, conforme se dispuser em regulamento:
} 
I - a pesquisa científica;

II - a visitação com objetivos turísticos, recreativos e educacionais;

\section{III - VETADO}

$\S 3^{\circ}$ Os órgãos integrantes do SNUC, sempre que possível e oportuno, prestarão orientação técnica e científica ao proprietário de Reserva Particular do Patrimônio Natural para a elaboração de um Plano de Manejo ou de Proteção e de Gestão da unidade.

Mas embora as RPPNs constem como Unidades de Uso Sustentável, acabaram sendo estabelecidas como Unidades de Proteção Integral, a partir do veto ao item III do $\S 2^{\circ}$, que facultava a exploração sustentável dessa áreas ${ }^{74}$.

Entre os benefícios assegurados por lei aos proprietários de RPPNs estão ${ }^{75}$ :

- Direito de propriedade preservado;

- Isenção do Imposto sobre a Propriedade Territorial Rural (ITR) referente à área criada como RPPN;

- Prioridade na análise dos projetos, pelo Fundo Nacional do Meio Ambiente - FNMA;

- Preferência na análise de pedidos de concessão de crédito agrícola, junto às instituições oficiais de crédito, para projetos a serem implementados em propriedades que contiverem RPPN em seus perímetros;
${ }^{74}$ Segundo PÁDUA (2007) houve muita pressão, principalmente por parte de grandes latifundiários de terras na Amazônia, para que as RPPNs fossem de uso sustentável. Estes tinham como real intuito impedir invasões e desapropriações em suas posses bem como a isenção dos impostos territoriais. Este artifício, que colocava em xeque o próprio SNUC, foi combatido pelo Ibama e organizações ambientalistas que conseguiram junto ao Presidente da República sua anulação. Por isso o remendo da lei, que causa ainda muita confusão.

${ }^{75}$ Fonte: IBAMA (2007). 
- Possibilidades de cooperação com entidades privadas e públicas na proteção, gestão e manejo da RPPN

Estas unidades, que são facilmente criadas, têm se mostrado um mecanismo efficiente no aumento do número de áreas protegidas no país, possibilitando neste processo a participação da iniciativa privada. PÁDUA (2007) informa que o número destas áreas, entre estaduais e federais, já ultrapassa 500 (somando mais de 500.000 hectares), em sua maioria muito bem manejadas, não raro apresentando planos de manejo, infra-estrutura adequada e pessoal capacitado tanto a exercer sua fiscalização quanto a atender seus visitantes. 


\subsection{A criação de RPPNs em Sarandira.}

Observemos algumas considerações quanto à possibilidade de criação de uma rede de RPPNs no distrito.

Embora não exista qualquer restrição legal às dimensões mínimas de área passíveis de conversão em RPPNs ${ }^{76}$, a instituição desta categoria de UC no distrito de Sarandira, grosso modo, partiria basicamente daqueles fazendeiros que são detentores de fragmentos florestais ou recursos hídricos de grande valor paisagístico ou ecológico, e não dos demais proprietários de terra, como sitiantes, bem como dos moradores de seus dois povoados, estes últimos, residentes em pequenos lotes de dimensões urbanas, desprovidos daqueles atributos. A descontinuidade dessas UCs seria um fator importante a se considerar.

Sendo as RPPNs uma categoria do SNUC voltada à proteção da biodiversidade, nas terras como tal declaradas a produção agropecuária não seria permitida. Há que se ter em mente que as terras da região, ainda que contendo resquícios de fauna e flora importantes, são bastante antropizadas. As pastagens para o gado ocupam cerca de $80 \%$ de sua superfície, e a atividade pecuária, ainda que mal remunerada, é o que mantém aquelas propriedades rurais. Seu abandono seria, para muitos, arriscado. Para contornar o problema, a solução mais usual para a compatibilização de ambas atividades, agropecuárias e de conservação da biota, seria a decretação da UC apenas em parte da propriedade, não em sua totalidade. Mas este artifício, comum a muitas RPPNs, dificultaria a formação de áreas preservadas contíguas, não resolvendo por completo os graves problemas do isolamento dos fragmentos florestados. Por outro lado, esta mesma característica
76 Pelo Decreto $n^{\circ} 1.922 / 96$ as RPPNs devem possuir relevante importância, pela sua biodiversidade, por seu aspecto paisagístico ou por possuir características ambientais que justifiquem sua recuperação. Atendendo a pelo menos um destes critérios, não há qualquer restrição quanto aos limites, mínimos ou máximos, de sua área. 
77 Em seu aspecto mais geral, as atividades compatíveis com as RPPNs são as de cunho científico, cultural, educacional, recreativa e de lazer. pode exemplificar a flexibilidade e autonomia trazidas pelas RPPNs às suas terras e seus proprietários - o que certamente tem influído em sua crescente popularização no país - podendo ser, por esta razão especificamente, estimulado no distrito de Sarandira.

Mas outra característica dessas unidades que é seu caráter de perpetuidade, ao mesmo tempo em que representa uma sólida estratégia para a conservação ambiental da propriedade, pode dificultar sua venda. Tanto os herdeiros dessas terras quanto seus futuros compradores terão que respeitar as determinações legais, não havendo meios de revogá-las. Esse aspecto é particularmente importante quando se avalia a região em questão, onde a compra e venda de terras é um processo de alta rotatividade.

Outro ponto importante é que a isenção do Imposto Territorial Rural (ITR), o mais conhecido incentivo oferecido aos donos de RPPNs, não parece ser suficientemente forte para impulsionar a popularização local destas UCs. Isto porque este tributo é pouco oneroso, pelo próprio tamanho dos sítios e fazendas do distrito. É provável que a isenção do ITR represente uma vantagem concreta apenas aos muitos latifúndios improdutivos espalhados pelo país, mas não àquele distrito.

Feitas essas considerações, há ainda outros empecilhos à decretação maciça de RPPNs em Sarandira que também merecem destaque. Sua criação em um futuro próximo, na dependência de enormes esforços, parece ser muito pouco provável. A atratividade de seus recursos naturais, com força suficiente para impulsionar a visitação pública e valendo-se de atividades culturais e de lazer, basicamente as únicas alternativas possíveis de geração de renda ${ }^{77}$ que justificariam o abandono total ou parcial da agropecuária, se restringiria, 
sobremaneira, àquelas terras que abrigam vastas áreas florestadas, cachoeiras ou paisagens excepcionais. Teoricamente todas essas limitações, importante destacar, podem ser completamente superadas através do emprego de estratégias bem engendradas, dotação de infra-estrutura voltada ao turismo e marketing, como aponta VEIGA (2003, p. 42), lembrando que patrimônio também se constrói:

(...) a valorização do patrimônio é um meio de criar recursos específicos com o envolvimento dos atores locais. Isso permite principalmente a construção de uma imagem de marca identitária do território, da mesma forma que uma empresa elabora cuidadosamente um símbolo que a ajude a fidelizar uma clientela, ou conquistar um novo segmento de mercado. Por isso, a valorização do patrimônio natural e histórico-cultural é muito mais um processo de construção do que uma herança.

Portanto, ainda que não seja inviável sua realização, e ainda que a própria legislação referente às RPPNs destaque a possibilidade de "cooperação com entidades privadas e públicas na proteção, gestão e manejo da RPPN”, estas ações encontrariam fortes obstáculos, por dependerem demasiadamente de iniciativas pessoais, principalmente entre os grandes fazendeiros, que são os que abrigam em suas terras a maior parte dos atributos ambientais da região. E aqueles, como já descrito anteriormente, e salvo algumas exceções, não são demasiadamente envolvidos com questões pertinentes à região, por isso, acabam criando um duplo entrave ao aproveitamento das oportunidades trazidas com a 
criação de RPPNs: falta de empreendedorismo e capacidade de articulação.

Em síntese, esta categoria de manejo, que tem concretamente como maiores trunfos a manutenção da propriedade privada da terra e sua facilidade de criação, se for empregada como estratégia única para promover a conservação ambiental da região em sintonia com seu desenvolvimento, dificilmente alcançaria êxito. Adotar um outro tipo de UC, a APA, parece ser o meio mais adequado para se atingir tais objetivos. 


\subsection{A instituição de uma APA em Sarandira.}

Diante da necessidade de superar os problemas ambientais e socioeconômicos encontrados no distrito de Sarandira, a criação de uma APA parece representar a opção mais adequada se a compararmos com as outras várias categorias de áreas protegidas disponíveis no Brasil. Para isso pesam algumas questões, com destaque para o fato de que a compatibilização da conservação da biodiversidade com o desenvolvimento econômico em regiões que apresentam uma grande heterogeneidade de ambientes é a característica mais notável desta categoria de $\mathrm{UC}^{78}$.

No distrito de Sarandira, a realidade muito diversa de seus dois núcleos urbanos e de seu entorno, bem como a própria heterogeneidade dos indivíduos atrelados a esses ambientes, desde agricultores familiares, fazendeiros forasteiros e exmoradores urbanos recém instalados, exige não apenas um tratamento específico para cada área mas, paralelamente, uma visão de conjunto, uma abordagem integradora, que se justifica por algumas razões. A interdependência desses espaços, ainda que tenha sido muito maior no passado, ainda persiste. Seu relativo isolamento geográfico, embora em muito atenuado pelas melhorias nas estradas e pela popularização dos meios de transporte motorizados, também continua. Sua identidade, ainda que o distrito e a cidade constituam um todo articulado, é reforçada por sua delimitação político-administrativa. Diante disto, tendo em vista a ineficiência das políticas de ordenamento territorial, tanto urbano quanto rural, no distrito, a APA pode vir a ser um poderoso indutor de estratégias voltadas à qualidade ambiental da região.
78 As Reservas da Biosfera, que em muitos aspectos se assemelham às APAs, e por isso poderiam se mostrar apropriadas, foram decretadas em apenas sete áreas do território brasileiro, em áreas extensas, mais comumente abrigando a quase totalidade de alguns biomas, como por exemplo as Reservas da Biosfera da Mata Atlântica e do Cerrado. 
O perímetro desta APA, optando-se pela coincidência com os próprios limites do distrito, traria maior facilidade à sua gestão, esquivando-se da interferência de diferentes municipalidades que, em um primeiro momento, poderia ser um fator de desagregação. Assim, a não vinculação a condicionantes físico-ambientais ou à abrangência do patrimônio arquitetônico remanescente do ciclo cafeeiro da região teria como objetivo a delimitação de uma zona piloto, uma agência de desenvolvimento sustentável capaz de disseminar as futuras experiências de sucesso por seu entorno, pequenos municípios e suas zonas rurais, que guardam muitas familiaridades com o distrito de Sarandira.

Objetivamente, a APA poderia ser um instrumento eficaz para ordenar a expansão de Caeté e para atender às necessidades básicas de seus habitantes através da dotação de infra-estrutura adequada, melhorias em saúde e educação, ao mesmo tempo em que a atenção às questões ecológicas seria também uma das prioridades.

Algumas medidas estratégicas poderiam ser elaboradas visando melhorias socioeconômicas para a vila de Sarandira, atenuando seu caráter de ilha. Empresas familiares e pequenas indústrias voltadas à transformação de bens primários teriam papel de destaque neste sentido.

Todas as propostas de salvaguarda do patrimônio presente no distrito de Sarandira, seus atributos naturais e histórico-culturais, ganhariam maior visibilidade. Incentivos e parcerias poderiam ser mais facilmente consolidados por seu órgão gestor, em contato com as iniciativas pública e privada. Empresas com passivos ambientais poderiam se regularizar, financiando projetos de recuperação ambiental na região. Pesquisas e transferência de tecnologias relativas à produção agropecuária poderiam ser realizadas no distrito, que se 
converteria em área piloto para tais experimentos ${ }^{79}$.

Outro ponto a se considerar é a vinculação de sua produção agropecuária hoje basicamente voltada à venda de leite in natura aos laticínios da cidade por meio de cooperativas locais - a nichos de mercado mais rentáveis, através da agregação de valor ao produto final. Laticínios instalados em seus dois povoados poderiam se somar às atuais cooperativas, gerando maior demanda por mão-de-obra local. A conversão da produção tradicional em orgânica, ou mesmo o atrelamento do produto e sua marca a uma unidade de conservação da natureza, se adequariam a critérios éticos, ecológicos e de responsabilidade social, hoje tão em voga.

Os atributos presentes na região precisariam ser tratados como trunfos que, responsavelmente explorados, ofereceriam uma alternativa concreta para a melhoria da condição de vida de seus moradores. E para tanto, uma das estratégias passaria pelo incentivo à visitação pública, seja pela via do turismo histórico-cultural, de natureza, ou ambos. Estes se valeriam de sua ligação a redes mais amplas, como a da exploração turística da Estrada Real, rota que já tem trazido benefícios a pequenas cidades por ela atravessada, e que vem recebendo cada vez mais investimentos por parte dos governos estaduais e municipais, e diversos setores empresariais.

A partir do Zoneamento Ambiental seriam definidos os potenciais e os limites de uso em cada área, proibindo ou restringindo a expansão dos povoados, o parcelamento do solo para fins urbanos, as atividades minerárias, industriais, tratamento e disposição de resíduos sólidos, entre outras determinações. Dentro deste contexto sistêmico pretendido, a promoção da interconectividade entre
${ }^{79}$ Uma parceira fundamental nestas ações seria a Embrapa Gado de Leite, uma das 40 unidades descentralizadas da Empresa Brasileira de Pesquisa Agropecuária espalhadas pelo território nacional que, não por acaso, é sediada em Juiz de Fora.

Seus maiores objetivos - que também se alinhariam aos objetivos gerais da APA em questão - são (EMBRAPA, 2007): "viabilizar soluções para o desenvolvimento sustentável do agronegócio do leite, com ênfase no segmento da produção, por meio de geração, adaptação e transferência de conhecimentos e tecnologias, em benefício da sociedade." 
${ }^{80}$ Ainda que a qualidade ambiental interesse a toda a sociedade. fragmentos florestais, internos e externos ao distrito, seria uma das ações prioritárias. No mesmo sentido, o Zoneamento Ambiental não poderia prescindir de sua articulação com os demais instrumentos de ordenamento territorial do município de Juiz de Fora e seu entorno. Este seria um grande desafio, já que as políticas territoriais e ambientais costumam ser pensadas de forma desconexa (UNESCO, 2003, p.17):

Como as configurações territoriais foram concebidas a partir de forças políticas/econômicas, com diferentes escalas espaciais e temporais, a natureza foi cada vez mais excluída e esquecida no processo de ordenamento territorial. O resultado dessa não-compatibilização dos eventos noespaço-tempo, é a criação de mosaicos de formas e políticas públicas urbanas, rurais e ambientais desconexas e conflitantes. Em síntese, um ordenamento territorial fadado ao fracasso, uma vez que a natureza não reage "aos pedaços", a partir de políticas setoriais.

Comparada às RPPNs, que são voltadas, basicamente, a interesses privados ${ }^{80}$, a criação da APA representa a oportunidade e também o desafio de distribuir de forma igualitária as responsabilidades e os benefícios trazidos com a preservação ambiental. O que coloca em jogo a capacidade de definição de objetivos comuns e de organização de todos os interessados em sua decretação, com destaque para seus moradores permanentes, os que mais seriam afetados pelas transformações no distrito. Questão esta que lança luz sobre a ineficiência de muitas UCs dessa categoria de manejo no Brasil, muitas delas, indubitavelmente, "ficções jurídicas". 
Para obter sucesso aquela comunidade precisa conhecer seu papel, seus direitos, visualizar as oportunidades disponíveis e ser participativa, atuando diretamente em seu zoneamento e sua gestão ${ }^{81}$. Como nas RPPNs, as terras declaradas APAs podem ser públicas ou privadas, eliminando o ônus gerado com as possíveis indenizações, que tanto dificultam a efetivação das UCs brasileiras.

Em síntese, uma proposta que visa um objetivo imodesto, a perseguição do desenvolvimento sustentável, pressupõe, portanto, o entendimento de um espaço único, em que campo e cidade, conservação ambiental e crescimento econômico não existem isoladamente, devendo ser pensados em suas interrelações ${ }^{82}$.

Por suas características o Zoneamento Ambiental atuaria como uma ferramenta apropriada para o tratamento sistêmico dos problemas ambientais, algo que o Plano Diretor municipal não tem sido capaz de realizar. Mas esta também tem se mostrado uma deficiência generalizada deste tipo de instrumento (UNESCO, 2003, p. 27), não uma exclusividade local:

Como os planos diretores foram concebidos para atender basicamente às necessidades de disponibilidade de terras urbanas, na sua correlação com a problemática habitacional, a maioria desses instrumentos continua com uma visão segmentada e míope do espaço. (...) O resultado é que as metodologias de planos diretores não contemplam os impactos das propostas de expansões urbanas sobre as áreas naturais e espaços agrícolas, nem a capacidade de suporte dos sistemas naturais.
${ }^{81}$ Ao lado de representantes dos órgãos públicos e de organizações da sociedade civil que devem, conjuntamente, formar o órgão responsável pela administração da APA, pela Lei 9985/2000 (Art. $15)$.

82 “(...) o espaço geográfico passa a ser visto como uma teia interconexa de relações, onde as questões urbanas, rurais, sociais, culturais, econômicas, políticas e de preservação, são tratadas com o mesmo "peso", em uma visão sistêmica." (UNESCO, 2003, p. 19) 
Por tudo isso, a APA distrital de Sarandira pode vir a tornar-se uma alternativa viável para enfrentar alguns de seus problemas mais expressivos, sem perder de vista as premissas de conservação e recuperação ambiental e paisagística da região. 


\section{CAPÍTULO}

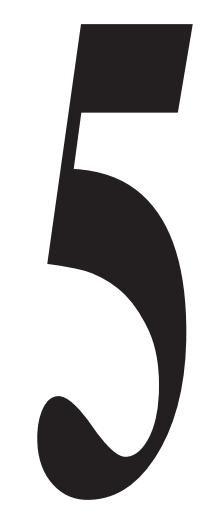




\section{5 - Considerações à espacialização da APA de Sarandira}

Partiremos da proposta de criação de uma Área de Proteção Ambiental (APA) em Sarandira, problematizando algumas questões fundamentais quanto aos objetos, objetivos e métodos relacionados à sua conservação. Quaisquer que sejam os dispositivos voltados a esse fim - seja por meio de uma APA, RPPNs ou ainda outra categoria de UC - um aspecto crucial a se ter em conta em seu zoneamento é o que proteger e como proteger, e como essas medidas afetarão o redesenho de sua paisagem.

Vimos que a região compreende bens naturais e culturais notáveis que precisam ser conservados. Mas vimos também que isso não é tudo. São igualmente necessários esforços de reconstrução e medidas de adequação e controle em alguns locais, visando alcançar um cenário futuro desejado, uma paisagem que expresse atenção no que tange a questões socioambientais e históricoculturais. Neste sentido, a discussão quanto ao Código Florestal torna-se um ponto importantíssimo que precisa ser retomado e aprofundado.

Como será apresentado nas próximas páginas, de um lado, o estrito cumprimento da legislação referente à recomposição de APPs e Reservas Legais no distrito e, de outro, a manutenção de sua qualidade paisagística podem, por vezes, caminhar em sentidos opostos. É preciso fazer com que esses esforços se somem, resultando em planos concretos e exeqüíveis que promovam em última instância melhorias na qualidade de vida de seus moradores. 


\subsection{APPs e Reservas Legais: rebatimentos na paisagem}

Porções consideráveis do distrito de Sarandira, de acordo com o Código Florestal em vigor, deveriam estar destinadas à recomposição de sua vegetação nativa ${ }^{83}$. No entanto, se essa determinação tivesse sido cumprida à risca, se todas aquelas áreas fossem florestadas, teríamos como resultado uma paisagem ou segmentos de paisagens significativamente diferentes daqueles que se verificam na atualidade. Vejamos suas implicações.

Inegavelmente, se aquelas propriedades rurais estivessem em conformidade com a legislação, melhorias consideráveis teriam sido propiciadas em seu meio ambiente, através de medidas destinadas à proteção de seus solos e de seus recursos hídricos, que também se refletiriam no enriquecimento e na proteção de sua flora e fauna e, ainda, numa escala mais ampla, em todo aquele ecossistema.

De acordo com o Código Florestal, no que se refere às APPs do distrito de Sarandira, cerca de $40 \%$ de sua superfície deveria estar coberta pela vegetação nativa, tanto ao longo de seus cursos d'água quanto dispostas em seus topos de morro e escarpas de maior declividade. Devendo ainda ser acrescidas a estas, as Reservas Legais contribuiriam com mais, no mínimo, 20\% das terras distritais, como também determina a legislação, totalizando algo em torno de $60 \%$ de áreas de floresta.

Como se sabe, o que se constata em Sarandira é bem diferente. Somados, os fragmentos florestados totalizam apenas $15 \%$ de suas terras.
83 O Código Florestal, de 1965, determina que o proprietário rural recomponha em suas terras as APPs e Reservas Legais. O proprietário deve reflorestar o total dessas áreas em até 30 anos, podendo para tal recompor anualmente talhões que correspondam a, no mínimo, 1/30 de sua área. Como já se passaram mais de 40 anos desde a promulgação dessa lei, a rigor, houve tempo suficiente para a formação dessa vegetação, o que na prática não ocorreu. 


\section{LEGENDA}

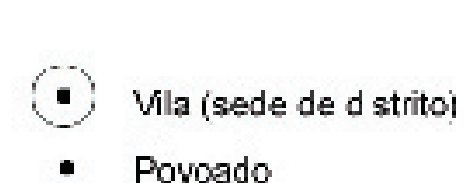

- Povoado

$\sim$ L mite de Municipio

- L L mite de distrito

— Cursos d'água

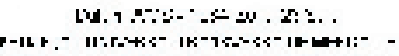

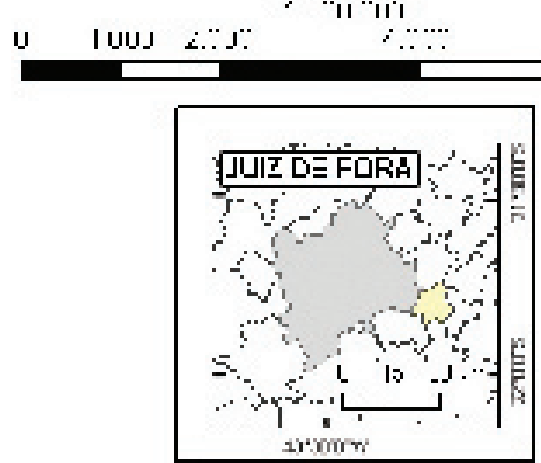

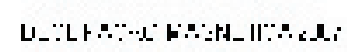

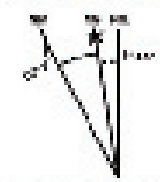

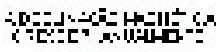
$y=$ roves:

LAd

ind

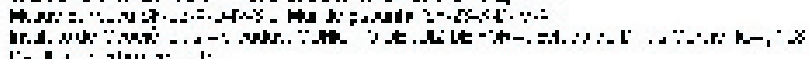

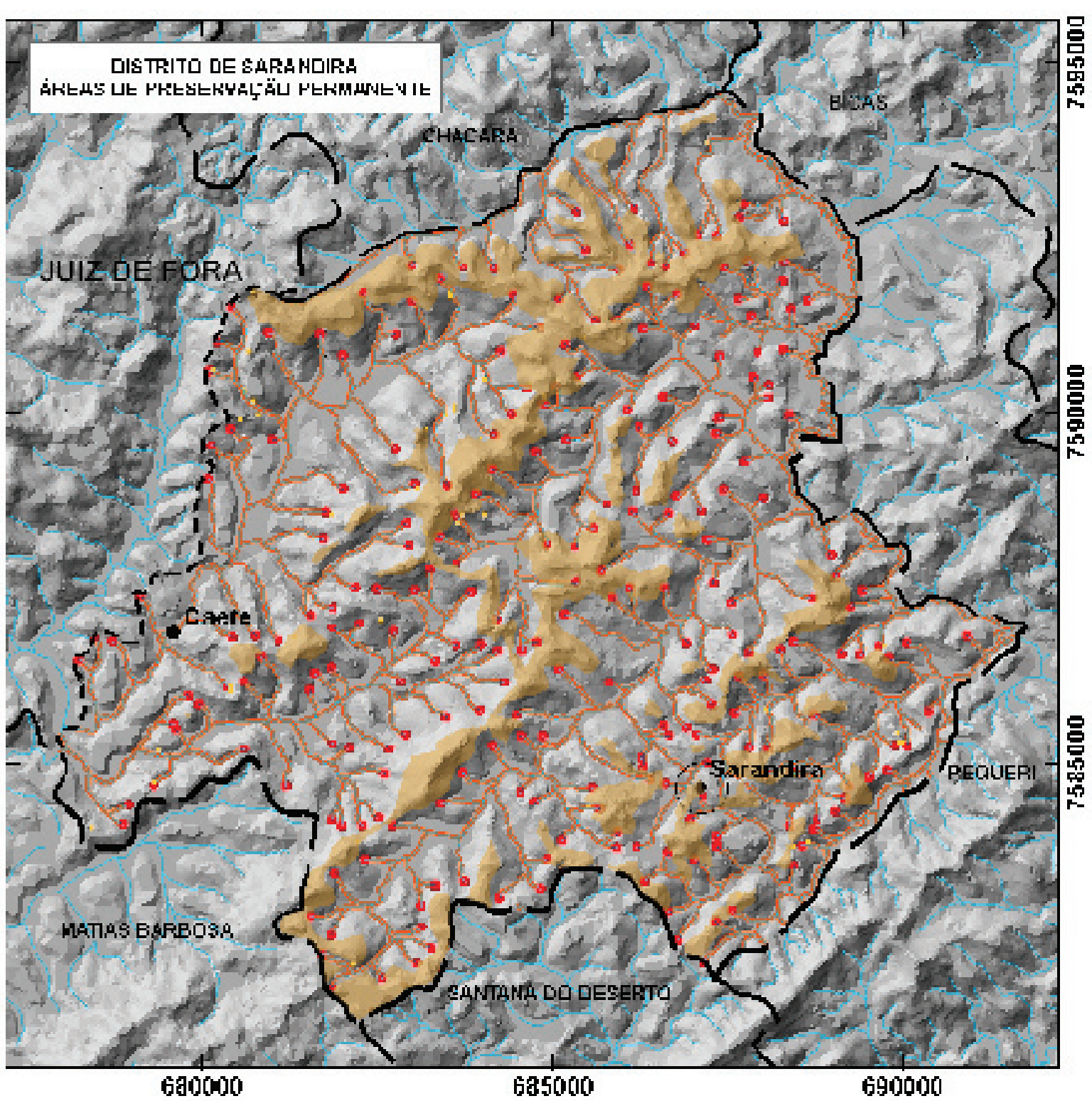




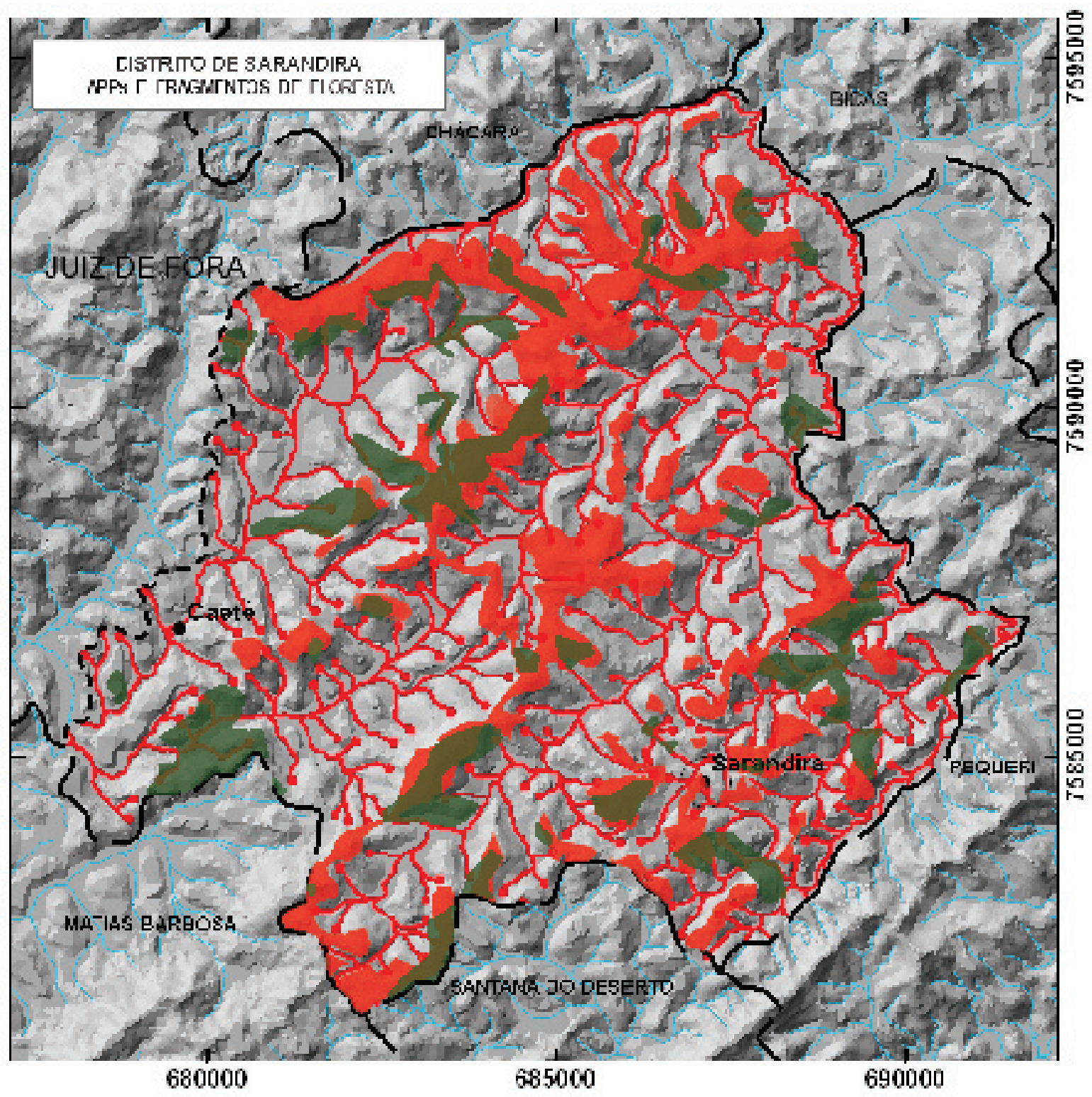

\section{LEGENDA}

(-) Vila isede de distrito)

- Povoaco

L Limite de Municipis

- -. Limile de distrito

Cursos d'àgua

APPs

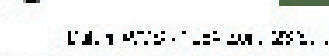

Florestas

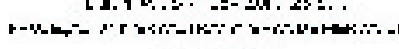
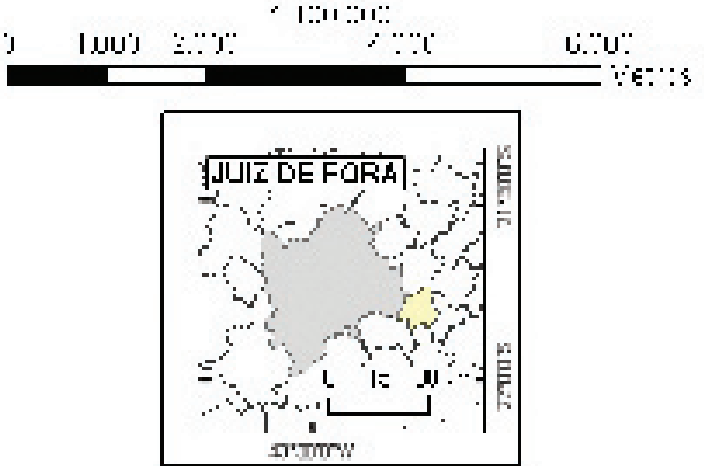

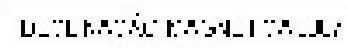

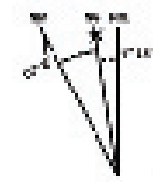

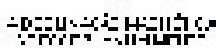

J.z:cro:are:

LAd

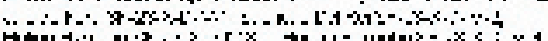

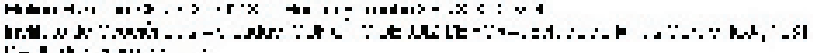


Os fatores que estão por trás desse quadro, comum à maioria das propriedades rurais no país, já foram listados anteriormente, destacando-se a falta de alternativas aos sistemas produtivos tradicionais.

Mas por que insistir nessa questão problemática, que vem sendo debatida sistematicamente ao longo de décadas por setores variados da sociedade, sem que tenha havido, na prática, avanços significativos o bastante para amenizar os descontentamentos por ela provocados? O fato é que o Código, ainda que falho, é vigente, e lança luz sobre um problema concreto e cada vez mais urgente: os impactos negativos causados em nosso meio ambiente e os caminhos para sua mitigação. Mas, principalmente, a questão está sendo aqui retomada por conta de um aspecto que tem implicação direta sobre a proposta de criação de uma UC em Sarandira: é que a legislação ambiental tende a recair de forma mais inflexível apenas sobre as áreas protegidas do país, por conta de sua maior visibilidade, enquanto que no restante do território nacional tudo parece ser permitido, na medida em que quase nada é fiscalizado.

Neste contexto, como as UCs de uso sustentável - a exemplo das APAs - estão formalmente baseadas no uso responsável de seus recursos naturais, e são criadas almejando-se a constituição de "agências de desenvolvimento sustentável" - como é costume se referir a elas - mais do que atribuir qualquer tipo de ônus decorrente de sua criação, deveriam ser desenvolvidos incentivos, facilidades e vantagens palpáveis para seus residentes e donos de terras, tendo em vista a conservação ambiental. Isso se torna mesmo imperativo em regiões como o distrito de Sarandira, fortemente antropizadas, em que as medidas de recuperação ambiental devem demandar enormes esforços, talvez até maiores do que aqueles destinados à sua simples manutenção. A recomposição de 
suas matas, voltada à proteção de áreas impactadas precisa ser energicamente perseguida, mas não às custas de maiores prejuízos à sua fraca economia. Como destacam TOURINHO \& PASSOS (2006):

\begin{abstract}
As limitações de usos da propriedade devem existir, porém consideradas as peculiaridades de cada uma delas, onde o bom senso para resolver os conflitos é importante, pois não se pode esquecer que o Estado é essencialmente agrícola e foi incentivado por muitos Governos para ser um grande produtor de alimentos como é hoje.
\end{abstract}

Assim, é fácil deduzir que estas soluções não são simples, já que se destinam a enfrentar pontos muito conflitantes, a atingir objetivos nada modestos. Demandam atenção pormenorizada, pois o meio rural não é homogênio, e em cada região se observam realidades muito distintas.

Mas esses são também problemas genéricos. A questão se torna ainda mais complexa quando novamente voltamos a atenção à proposta de criação de uma APA naquele distrito, onde a paisagem manejada pelo homem, durante séculos de profundas alterações do ambiente, tem uma relevância histórica e cultural inegável. Por conta disso, em seu zoneamento, o critério paisagístico teria um papel fundamental na conservação daquele patrimônio cultural ali presente.

Se em muitas propostas de Zoneamento Ambiental para APAs, as APPs são quase automaticamente declaradas como Zonas de Preservação da Vida Silvestre - em sintonia com o Código Florestal que classifica as APPs como destinadas quase que exclusivamente à recomposição florestal, e onde a intervenção humana 
84 A Resolução no 369, de 28 de março de 2006 dispõe sobre os casos excepcionais, de utilidade pública, interesse social ou baixo impacto ambiental, que possibilitam a intervenção ou supressão de vegetação em Área de Preservação Permanente. Resumidamente, no que tange às atividades agropecuárias, seriam apenas permitidas atividades de manejo agroflorestal sustentável em pequenas propriedades ou posses rurais familiares que não descaracterizem a cobertura vegetal nativa, ou impeça sua recuperação, e que não prejudiquem a função ambiental da área. Pelo visto, intervenções extremamente limitadas e destinadas apenas às famílias rurais de baixa renda. praticamente estaria vedada ${ }^{84}$ - no caso das antigas sedes de fazendas cafeeiras de Sarandira, para nos atermos inicialmente a esse exemplo mais óbvio, em sua esmagadora maioria assentadas sobre APPs, há que se propor outros tipos de uso do solo que não impliquem em uma completa descaracterização do que resta dessa paisagem cultural, por meio de seu simples abandono objetivando o crescimento das matas. Segundo FRANCO (2000, p.16):

Enquanto o Código se ocupa somente do aspecto florestal, ele desconhece que a maior parte do uso da terra não é mais florestal, e que as áreas de pastagem, principalmente, e de culturas agrícolas estão localizadas em margens de rio, topos de morro, encostas íngremes e outras APPs. Então, o que acontece é que o enfoque principal das leis ambientais é preservar aquilo que já não existe, e muito pouco se ocupa em buscar formas de modificar o que já existe.

Mas é também crucial que esta discussão não se limite aos entornos do conjunto arquitetônico que remete ao século XIX. A paisagem é dinâmica, é a expressão de vários tempos. Numa proposta em que critérios paisagísticos e não apenas estritamente ambientais devem nortear seu zoneamento, e tendo em vista a possibilidade de se testar e disseminar experiências de manejo sustentável dos recursos naturais, conforme compete às APAs, é preciso buscar uma adequação à legislação vigente também para as demais propriedades rurais, baseada em critérios conservacionistas, em substituição ao preservacionismo em seu sentido limitante. 
E também neste aspecto, no caso específico das APPs, o Código Florestal falha ao sugerir que as matas são o objeto de preservação e não seu instrumento, como explica FRANCO (2000, p.15) ${ }^{85}$ :

Se uma mata ciliar se destina à conservação ou à preservação das margens e, em última análise, da água, ela é claramente um simples instrumento de preservação, já que o objeto de preservação é a água. Então, essa vegetação poderia ser uma floresta produtiva, onde o agricultor plantaria e colheria árvores nativas, desde que seja obedecido um plano de manejo que não deixe sem proteção o objeto de preservação. Com essa política, o agricultor voltará a ser dono de suas terras, pois atualmente ele as divide com o Estado, por força de uma legislação que administra a maior parte da propriedade.
${ }^{85}$ As Reservas Legais, ao contrário, destinam-se à manutenção da vegetação nativa. A mata é o próprio objeto de preservação.

Assim, deveria ser considerada a proposta de uso desses ambientes, atendose primordialmente aos objetivos de sua conservação, baseando-se em critérios técnicos. Autores como GONÇALVES (1992) ressaltam nesse caso a necessidade de um alinhamento da legislação ambiental às novas tendências de conservação, em que o preservacionismo ceda lugar ao tecnicismo para a superação desses problemas. 


\subsection{Diretrizes gerais para um plano de paisagem em Sarandira}

Uma proposta de uso do solo para o distrito de Sarandira, destinada à melhoria de sua qualidade ambiental em seu sentido mais amplo, ou seja, em seus processos ecológicos, econômicos e sociais deve, igualmente, privilegiar sua paisagem como atributo a se manter e se requalificar. De fato, rigorosamente, pode-se constatar que paisagem e ambiente, então tomados como dimensões ou sentidos distintos, tendem na prática a se confundir, a atenuar seus limites, à medida em que as preocupações com o bom funcionamento do ambiente, de seus processos dinâmicos, se traduzem automaticamente - ainda que não imediatamente, e nem sempre de forma clara - em sua materialização, em sua paisagem. Tratando-os como dimensões distintas, como aqui se fez, procura-se enfatizar a necessidade de se conduzir os processos ambientais considerando também a forma como estes se rebaterão na paisagem, ou seja, a forma como possibilitarão sua leitura.

Nesta proposta é importante que seus mais notáveis bens naturais e culturais sejam ressaltados, sejam organizados de forma a possibilitar ao observador orientar-se, entender a disposição dos elementos que constituem a cena bem como organizá-los de modo a poder constatar os muitos anos de trabalho sobre aquelas terras, perceber seu valor enquanto patrimônio.

Portanto, em resumo, é importante que seus traços históricos sejam mantidos e que sua qualidade ambiental seja incrementada e também adequada à legislação vigente. Do somatório destas preocupações deve resultar sua paisagem. 
Nessa inseparabilidade dos valores ambientais e paisagísticos, as unidades de paisagem identificadas no capítulo 3 são também unidades ambientais, com processos naturais e culturais particulares. Podem, portanto, subsidiar um zoneamento que contemple todo o rol das necessidades a serem atendidas.

Na unidade vilarejo, para Caeté, e mesmo ao longo da via que permite o acesso a este povoado, é importante restringir os adensamentos, propondo medidas mínimas de área para terrenos e definindo medidas máximas para sua taxa de ocupação. Os aspectos arquitetônicos, com seu grande efeito sobre a paisagem, devem ser também observados, especialmente no que se refere ao gabarito das construções e suas coberturas, tendo como referência a arquitetura rural tradicionalmente estabelecida na região. Os futuros loteamentos nas áreas que circundam o povoado devem privilegiar a constituição de sítios e granjas, evitando-se o parcelamento em lotes de dimensões tipicamente urbanas.

Essas mesmas diretrizes são válidas para a vila de Sarandira onde, como visto, melhorias de sua infra-estrutura e de reaquecimento de sua economia serão estratégicas para fixar sua reduzida população, bem como atrair novas famílias de regiões próximas. O que resta do patrimônio arquitetônico nesses dois povoados deve ser prioritariamente conservado.

Nas unidades núcleos das propriedades rurais é urgente a necessidade de se recuperar proteger os bens arquitetônicos e culturais notadamente representados pelas antigas fazendas cafeeiras. Nestas e nas demais propriedades o desafio maior é a compatibilização da produção agropecuária com a proteção ambiental, baseada em critérios técnicos e ainda tendo como referência o Código Florestal, especialmente no que se refere às APPs de cursos d'água e nascentes. 
Como evolução daquelas práticas mais impactantes tradicionalmente empregadas uma boa opção é a adoção de sistemas agroflorestais.

Nas unidades de invernadas e unidades florestais a regeneração e a preservação das matas são prioridades. Os trechos cruciais para a manutenção dos recursos hídricos, contenção de encostas e ainda aqueles mais propícios à formação de corredores de fauna entre os fragmentos florestados existentes serão preferencialmente destinados à preservação, devendo ser neles desenvolvidas atividades de baixo impacto como as de fins científicos e de educação ambiental. As demais áreas, como aquelas fartamente representadas pela maioria das pastagens que ocupam APPs de topos de morros, podem tanto prestar-se à conversão integral em matas, quanto podem ser destinadas à silvicultura com espécies nativas ou ao silvipastoreio. Atividades de lazer devem também ser incentivadas nesses espaços.

Assim, busca-se um zoneamento que privilegie aquela paisagem não enquanto um cenário congelado, mas como manifestação do uso responsável de seus recursos naturais e de valorização de sua história. 


\section{Conclusão}

Ao longo das páginas passadas procurou-se, de início, contextualizar o potencial contido em muitas zonas rurais diante da urgente necessidade de atenuar os danos infringidos ao ambiente, associados ao usual modelo vigente de progresso. Por sua abrangência territorial e por sua representatividade na cultura nacional, o campo não deve ser tratado como um mero resquício de nosso passado e fadado ao desaparecimento. Para isso é vital que as políticas públicas superem a míope visão que associa o rural com o arcaico e, por extensão, a cidade com o moderno, e voltem sua atenção às suas características intrínsecas de modo a poder potencializar suas virtudes.

Através do estudo do distrito de Sarandira foi possível constatar o rebatimento destas mesmas questões, supostamente tão comuns a muitas outras regiões do País. Isso ficou evidente com o desorganizado avanço de parte da mancha urbana de Juiz de Fora em direção àquele distrito - em certo sentido estimulado e observado à distância pela administração municipal - que já se reflete no considerável crescimento de Caeté nos últimos anos. Por sua atratividade, representada de um lado por sua proximidade com o centro da cidade e seu acesso agora facilitado e, de outro, por suas paisagens bucólicas, a cada dia mais valorizadas, essa transformação está apenas começando a se desenrolar. Neste processo, ironicamente, muitos atributos que têm atraído novos moradores vão se perdendo à medida que eles se instalam, já que os grandes adensamentos são incompatíveis com a manutenção de sua qualidade ambiental e paisagística, como também o são as linguagens arquitetônicas tipicamente urbanas, as 
elevadas concentrações populacionais e muitas das mazelas a elas associadas.

Com a pesquisa procurou-se, também, identificar aqueles referenciais naturais e culturais mais valiosos presentes no distrito. Ao se avaliar o seu território em conjunto confirmou-se que, embora não se verifique o caráter de exceção que costuma caracterizar as áreas naturais merecedoras de políticas de proteção, há nele uma série de elementos de grande interesse para a coletividade. Entre estes, o que restou das edificações do período cafeeiro emerge como um bem importantíssimo. Também, como foi visto, diante de seu abandono, medidas emergenciais devem ser tomadas visando sua recuperação.

Já com relação ao seu patrimônio natural, outro item de valor excepcional, o passar do tempo trouxe alguns benefícios notáveis, constatados pelo significativo aumento de sua área total florestada. Este incremento, verificado inicialmente pela comparação entre imagens recentes de satélites e o mapa que retrata Juiz de Fora na década de 1930 - em que pese neste último algumas possíveis imprecisões, como a provável não representação das matas de dimensões muito pequenas - foi também confirmado tanto pelos relatos dos moradores locais mais idosos quanto pelas referências literárias sobre o pretérito ciclo cafeeiro e seus impactos àquela região. Muitos destes atuais fragmentos, por não passarem de capoeiras jovens, refletem não só uma maior consciência em relação à manutenção do equilíbrio ecológico por parte dos proprietários rurais em anos recentes mas, principalmente, simbolizam o atual estado de fraqueza da economia local - inaugurado com o fim da cafeicultura, há várias décadas, mas ainda hoje vigente - e que resultou em muitas áreas de pastos ou plantações simplesmente abandonadas. Mas essas matas - que curiosamente ainda abrigam animais ameaçados de extinção, como o macaco-barbado - por sua distribuição, 
forma e tamanho, são ainda insuficientes diante da urgente necessidade de proteção de seus solos, de seus recursos hídricos e dos demais componentes da fauna e da flora nativos, que já não podem mais ser encontrados ou estão sob risco de se extinguirem.

Com relação à evolução futura desta paisagem, a continuarem os processos hoje percebidos, pode-se fazer algumas considerações. Entre estas, tendo em vista o fato de que alguns terrenos de topografia mais desfavorável têm sido recentemente abandonados, presume-se que as áreas totais florestadas se ampliarão, ainda que levemente. Com isso, as pastagens devem passar por uma ligeira redução, embora, provavelmente, pouco perceptível diante de sua magnitude. Já nas baixadas, as áreas mais intensivamente utilizadas nas propriedades rurais, não há a expectativa de alterações relevantes, tanto em seu uso quanto em sua fisionomia.

Ainda dentro desta prospecção de cenário, a área urbanizada correspondente ao povoado de Caeté deverá ter uma expansão considerável, tanto com o adensamento de suas partes já consolidadas quanto com seu crescimento ao longo de sua via principal. Nesta, entre o povoado e a cidade de Juiz de Fora, outros loteamentos são esperados.

O futuro da vila de Sarandira, por outro lado, ainda é de difícil previsão. Mas uma das consequiências da aproximação das franjas da cidade até Caeté é que a vila de Sarandira ganhará, numa etapa posterior, maior atenção, tornando-se um destino mais acessível e conhecido por um número crescente de pessoas, o que poderá despertar interesse quanto ao estabelecimento de casas de campo e chácaras de lazer. Lembrando-se do papel estruturante da acessibilidade, podem vir a ser decisivas neste processo melhorias na estrada Caeté-Sarandira. 
Destino semelhante teriam muitas fazendas e sítios espalhados pelo distrito. A progressiva subdivisão de seu território tem sido uma tendência histórica, que não arrefeceria agora com a grande demanda por melhor qualidade de vida, ainda mais quando se coloca em perspectiva as oportunidades de negócio daí decorrentes em contraste com os baixos lucros colhidos com a pecuária local.

Diante desse quadro, dessas certezas e incertezas que cercam seu futuro, a proposta de criação de uma Área de Proteção Ambiental no distrito de Sarandira parece ser adequada, como um mecanismo supostamente capaz de dar conta de cada uma de suas maiores particularidades de forma sistêmica, já que, por princípio, aliaria preocupações ambientais e socioeconômicas. E quanto à hipótese levantada de criação de Reservas Particulares do Patrimônio Natural, mesmo que se tenha conduzido a exposição para os maiores benefícios referentes à outra categoria de UC, não significa que deveria ser desconsiderada. Pelo contrário. Para estas, a APA poderia ter um efeito aglutinador e protetor. Paralelamente, as RPPNs reforçariam os objetivos conservacionistas perseguidos com a criação da APA.

Ainda com relação a esta proposta, representam um grande desafio para a sua realização a necessidade de se adequar suas propriedades rurais às leis ambientais vigentes. Também chama-se a atenção para o fato de que a aplicação do Código Florestal carece de uma análise mais criteriosa, de uma interpretação mais aprofundada de suas disposições, sob o risco de permanecer sendo negligenciada.

Como síntese do que foi apresentado neste trabalho, alerta-se para a necessidade de se conservar os valores paisagísticos e ambientais do distrito de Sarandira, não só pelo que representam, mas pelo que ainda podem vir a representar, enquanto 
modelo para sua região. Para tal, como se viu, são necessárias medidas não apenas de proteção, mas também de recuperação em grande escala. E como isso não se realiza sem custos, os objetivos ambientais e econômicos não devem se distanciar. Assim, a decretação de uma Unidade de Conservação da Natureza local se justifica apenas se for efetivamente capaz de compatibilizar melhorias nas condições ambientais, sociais e econômicas locais, o que deve suscitar maiores estudos e uma ampla discussão entre todos os interessados. 


\section{Referências Bibliográficas}

Trabalhos citados no texto

\subsection{Livros}

AB`SÁBER, Aziz Nacib. Os domínios de natureza no Brasil: potencialidades paisagísticas. São Paulo: Ateliê, 2003.

ALMEIDA, J. A.; RIEDL, M. (Org.). Turismo rural: ecologia, lazer e desenvolvimento. Bauru: EDUSC, 2000.

ANTONIL, André João. Cultura e opulência do Brasil. Belo Horizonte: Itatiaia / EDUSP, 1982.

BESSE, Jean-Mac. Ver a terra: seis ensaios sobre a paisagem e a geografia / Jean-Marc Besse; tradução Vladimir Bartalini. - São Paulo: Perspectiva, 2006.

BONETE PERALES, R. Condicionamentos internos y externos de la PAC: eleccion, mantenimiento y abandono de la protección via precios. Madrid, Min. Agricultura, 1994. In: GRAZIANO DA SILVA, J. Políticas não-agrícolas para o novo rural brasileiro. In: ORNAs, Ocupações rurais não-agrícolas. Anais: oficina de atualização temática. Londrina: IAPAR, 2000.

BRITO, Maria Cecília Wey de. Unidades de Conservação, intenções e resultados. São Paulo: FAPESP / Anablume, 2000.

CAMPANHOLA, C.; GRAZIANO DA SILVA, J. O Agroturismo como nova fonte de renda para o pequeno agricultor brasileiro. In: ALMEIDA, J. A.; RIEDL, M. (Org.). Turismo rural: ecologia, lazer e desenvolvimento. Bauru: EDUSC, 2000.

CANDIDO, Antônio. Os Parceiros do Rio Bonito. São Paulo: Livraria duas Cidades, 1971.

CAVACO, Carminda. Turismo, comércio e desenvolvimento rural. In: ALMEIDA, J. A.; RIEDL, M. (Org.). Turismo rural: ecologia, lazer e desenvolvimento. Bauru: EDUSC, 2000. 
CHAUÍ, Marilena de Souza. Natureza, Cultura, Patrimônio Ambiental. In: LANNA, Ana Lúcia Duarte (coordenação). Meio Ambiente - Patrimônio Cultural da USP / Comissão de Patrimônio Cultural. São Paulo: EDUSP / Imprensa oficial do estado de São Paulo, 2003.

COSTA, José Pedro O. Aiuruoca: Matutu e Pedra do Papagaio. São Paulo: FAPESP / EDUSP / WWF, 1994.

COSTA MATOSO, Caetano. Diário da jornada que faz a Minas Gerais em 1749. In: Códice Costa Matoso: Coleção das notícias (...) \& vários papéis. Belo Horizonte: Fundação João Pinheiro, 1999.

DEAN, Warren. A ferro e fogo: a história e a devastação da Mata Atlântica brasileira. São Paulo: Companhia das Letras, 1996.

ELESBÃO, Ivo - O turismo como atividade não agrícola em São Martinho - SC. In: ALMEIDA, J. A.; RIEDL, M. (Org.). Turismo rural: ecologia, lazer e desenvolvimento. Bauru: EDUSC, 2000.

EMÍDIO, Teresa. Meio ambiente \& paisagem. São Paulo: Senac, 2006.

ENTRENA DURÁN, F. Cambios en la construcción social de lo rural. Madrid: Tecnos, 1998. In: FROEHLICH, José M. Turismo Rural e agricultura familiar: explorando (criticamente) o cruzamento de abordagens e estratégias para o desenvolvimento. In ALMEIDA, J. A.; RIEDL, M. (Org.) Turismo rural: ecologia, lazer e desenvolvimento. Bauru: EDUSC, 2000.

ESTEVES, Albino \& LAGE, Oscar Vidal Barbosa. Álbum do município de Juiz de Fora. Belo Horizonte: Imprensa oficial do Estado de Minas, 1915.

FROEHLICH, José M. Turismo Rural e agricultura familiar: explorando (criticamente) o cruzamento de abordagens e estratégias para o desenvolvimento. In ALMEIDA, J. A.; RIEDL, M. (Org.) Turismo rural: ecologia, lazer e desenvolvimento. Bauru: EDUSC, 2000.

GOLFARI, L. Projeto de desenvolvimento e pesquisa florestal: zoneamento ecológico do estado de Minas de Gerais para reflorestamento. Belo Horizonte, Centro de Pesquisa Florestal da Região do Cerrado, 1975. 65p.

GRAZIANO DA SILVA, José. Políticas não-agrícolas para o novo rural brasileiro. In: ORNAs, Ocupações rurais não-agrícolas. Anais: oficina de 
atualização temática. Londrina: IAPAR, 2000.

GRAZIANO da SILVA, J.; DEL GROSSI, M.E. O novo rural brasileiro. In: ORNAs, Ocupações rurais não-agrícolas: oficina de atualização temática. Londrina: IAPAR, 2000.

GUIMARÃES, Elione Silva. Múltiplos viveres de afrodescendentes na escravidão e no pós-emancipação: família, trabalho, terra e conflito (Juiz de Fora - MG, 1828-1928). São Paulo: Annablume, Juiz de Fora: Funalfa Edições, 2006.

LANNA, Ana Lúcia Duarte (coordenação). Meio Ambiente - Patrimônio Cultural da USP / Comissão de Patrimônio Cultural. São Paulo: Edusp / Imprensa oficial do estado de São Paulo / Comissão de Patrimônio Cultural, 2003.

LIMA, Eli Napoleão de. Novas Ruralidades, Novas Identidades. Onde? In: MOREIRA, Roberto José (Org.). Identidades Sociais: ruralidades no Brasil contemporâneo. Rio de Janeiro: DP\&A, 2005.

MARICATO, Hermínia. Brasil, cidades: alternativas para a crise urbana. Petrópolis, RJ: Vozes, 2001.

MARQUES, O.A.V. \& SAZIMA, I. 2004. História natural dos répteis da estação ecológica Juréia-Itatins. In Estação Juréia-Itatins: ambiente físico, flora e fauna (O.A.V. Marques \& V. Duleba, eds). Holos Editora, Ribeirão Preto, p. 257-277.

MARTINS, José de Souza. Capitalismo e tradicionalismo. São Paulo: Pioneira, 1975.

MAZUEL, Luc. Patrimônio cultural e turismo rural: o exemplo francês. In: ALMEIDA, J. A.; RIEDL, M. (Org.) Turismo rural: ecologia, lazer e desenvolvimento. Bauru: EDUSC, 2000.

MORAES, Antônio Carlos Robert. Geografia; pequena história crítica. São Paulo: Annablume, 2002.

MOREIRA, R. J. (Org.). Identidades sociais: ruralidades no Brasil contemporâneo. Rio de Janeiro: DP\&A, 2005.

OLIVEIRA, Mônica Ribeiro de. Negócios de Famílias: mercado, terra e poder na formação da cafeicultura mineira, 1780-1870. Bauru: EDUSC; Juiz de Fora, MG: FUNALFA, 2005 
PEREIRA DE QUEIROZ, Maria Isaura. Bairros Rurais Paulistas. São Paulo: Livraria duas Cidades, 1973.

PRADO Jr, Caio. História Econômica do Brasil. São Paulo: Brasiliense, 1990. In: MARICATO, Hermínia. Brasil, cidades: alternativas para a crise urbana. Petrópolis, RJ: Vozes, 2001.

PROCÓPIO FILHO, J. Aspectos da vida rural de Juiz de Fora. 1973.

RODRIGUES, Adyr Balastreri. Turismo rural no Brasil - ensaio de uma tipologia. In: ALMEIDA, J. A. ; RIEDL, M. (Org.). Turismo rural: ecologia, lazer e desenvolvimento. Bauru: EDUSC, 2000.

SAINT-HILAIRE, Auguste de. Segunda viagem do Rio de Janeiro a Minas Gerais e São Paulo. Belo Horizonte, Itatiaia, 1974.

SANTOS, Milton. Espaço e método. São Paulo: Nobel, 1985.

A natureza do espaço: técnica e tempo, razão e emoção. São Paulo: Hucitec, 1996.

SOTO, William Héctor Gómez. A produção de conhecimento sobre o “mundo rural” no Brasil; As contribuições de José de Souza Martins e José Graziano da Silva. Santa Cruz do Sul: EDUNISC, 2002.

STAICO, J. A Bacia do Rio Paraibuna em Juiz de Fora. Juiz de Fora: UFJF, 1976.

VEIGA, José Eli da. Cidades Imaginárias: o Brasil é menos urbano do que se calcula. Campinas: Autores Associados, 2003.

VELOSO, H. P.; RANGEL-FILHO, A. L. R.; LIMA, J. C. Classificação da vegetação brasileira, adaptada a um sistema universal. Rio de Janeiro: IBGE, 1991.

VILLAÇA, Flávio. Espaço intra-urbano no Brasil. São Paulo: Studio Nobel: FAPESP: Lincoln Institute, 2001.

ZUQUIM, Maria de Lourdes. Os caminhos do Rural: uma questão agrária ambiental. São Paulo: Editora Senac São Paulo, 2007. 
WALSH, Robert. Notícias do Brasil (1828 - 1829). Belo Horizonte: Itatiaia; São Paulo, EDUSP, 1985.

WILLIAMS, Raymond. O campo e a cidade na história e na literatura. São Paulo, Companhia das Letras, 1989.

\subsection{Teses e Dissertações}

BUENO, Ayrton Portilho. Patrimônio paisagístico e turismo na Ilha de Santa Catarina: a premência da paisagem no desenvolvimento sustentável da atividade turística. Tese de doutoramento apresentada à Faculdade de Arquitetura e Urbanismo da Universidade de São Paulo, 2006.

FRANCO, Fernando Silveira. Sistemas agroflorestais: uma contribuição para a conservação dos recursos naturais na Zona da Mata de Minas Gerais. Tese de doutoramento apresentada à Universidade Federal de Viçosa, 2000.

\subsection{Outros}

BRAGA, Roberto. Plano Diretor Municipal: três questões para discussão. Caderno do Departamento de Planejamento. Faculdade de Ciências e Tecnologia - UNESP - Presidente Prudente, vol 1, nº 1. Agosto de 1995, pp 15-20. Disponível em: www.rc.unesp.br/igce/planejamento/publicacoes/ TextosPDF/RBraga02.pdf. Acesso em: 05 abr. 2007.

BRASIL. Decreto ${ }^{\circ}$ 1.713, de 2 de agosto de 1937. Criação do Parque Nacional do Itatiaia. Disponível em: http://www.biodiversityreporting.org/ index.php?pageId=sub\&lang=en_US\&currentItem=article\&docId=7878\&c=Brazil\&cRef=Brazil\&year=2004\&date=September\%202003, Acesso em: 09 jun. 2007.

BRASIL. Decreto-lei no 25, de 30 de setembro de 1937 - Legislação referente à proteção do patrimônio natural. Disponível em: http://www.semarh . df.gov.br/semarh/site/cafuringa/Sec03/Sec_03_01a.htm. Acesso em: 02 jun. 2007. 
BRASIL. Lei n ${ }^{\circ} 4771$ de 15 de setembro de 1965. Institui o novo código florestal. Disponível em: http://www.planalto.gov.br/ccivil_03/Leis/L4771. htm. Acesso em: 24 out. 2007.

BRASIL. Lei n ${ }^{\circ}$ 6902, de 27 de abril de 1981. Dispõe sobre a criação de Estações Ecológicas, Áreas de Proteção Ambiental e dá outras providências. Disponível em:www.lei.adv.br/6902-81.htm. Acesso em: 14 out. 2007.

BRASIL. Lei $n^{\circ}$ 9.985, de 18 de julho de 2000. Institui o Sistema Nacional de Unidades de Conservação da Natureza - SNUC, estabelece critérios e normas para a criação, implantação e gestão das unidades de conservação. Disponível em: http://www.planalto.gov.br/ccivil/leis/L9985.htm. Acesso em: 13 out. 2007.

BRASIL. Lei nº 11.428/06, de 22 de dezembro de 2006. Lei da Mata Atlântica. Disponível em: http://www.planalto.gov.br/CCIVIL/_Ato20042006/2006/Lei/L11428.htm. Acesso em 02 set. 2007.

BRASIL. Decreto n 1.922 , de 05 de junho de 1996. Dispõe sobre o reconhecimento das Reservas Particulares do Patrimônio Natura. Disponível em : http://www.direitonet.com.br/artigos/x/29/06/2906/. Acesso em 16 set. 2007.

BRASIL - IBAMA. 1999. Roteiro Metodológico para a gestão de Área de Proteção Ambiental - APA. Disponível em: http://www.ibama.gov.br/ siucweb/guiadechefe/guia/anexos/anexo9/index.htm. Acesso em: 22 dez. 2007.

BRASIL - MMA. 2006. Ministério do Meio Ambiente. Plano Nacional de Áreas Protegidas (PNAP). Disponível em: http://www.mma.gov.br. Acesso em: 12 mai. 2006

BRASIL - MMA. 2007. Ministério do Meio Ambiente.Disponível em: http://www.mma.gov.br. Acesso em: 15 març. 2007.

COMMISSÃO GEOGRAPHICA E GEOLOGICA DE MINAS GERAES. Folha número 15. Mapa de Juiz de Fora (Palmira) Esc: 1/100.000, 1936.

COSTA, José Pedro de Oliveira. Patrimônio natural e estatuto de tombamento: reflexos sobre a estratégia de preservação. In: Revista do Patrimônio Histórico e Artístico Nacional nº 21, 1986. 
COSTA, José Pedro de Oliveira. A Reserva da Biosfera da Mata Atlântica. Disponível em: http://www.mre.gov.br/cdbrasil/itamaraty/web/port/ meioamb/arprot/tombadas/resbiosf/apresent.htm. Acesso em: 28 out. 2007.

EMBRAPA - Brasil em Relevo. Disponível em: http://www.relevobr.cnpm.embrapa.br/ Acesso em: nov. 2006.

EMBRAPA - Brasil Visto do espaço. Disponível em: http://www.cdbrasil.cnpm.embrapa.br. nov. 2006.

EMBRAPA - GADO DE LEITE. Disponível em: http://www.cnpgl.embrapa.br. Acesso em 26 dez. 2007.

GODOY, Mayr. A Lei Orgânica do Município Comentada, São Paulo, LEUD, 1990. In: BRAGA, Roberto. Caderno do Departamento de Planejamento. (Faculdade de Ciências e Tecnologia - UNESP) Presidente Prudente, vol 1, nº 1. Agosto de 1995, pp 15-20). Disponível em: www. rc.unesp.br/igce/planejamento/publicacoes/TextosPDF/RBraga02.pdf.

Acesso em: 05 abr. 2007.

GONÇALVES, W.A. Florestas: Objeto ou instrumento de preservação? In: Paisagem e Ambiente - Ensaios IV. São Paulo: FAUUSP, 1992. p. 189195

IBGE, Folha de Matias Barbosa. Esc: 1/50.000. 1993.

IBGE, Censo Demográfico 2000. Rio de Janeiro: IBGE.

IGA. Mapa do Município de Juiz de Fora. Esc: 1/100.000. 1981.

JUIZ DE FORA (MG). PREFEITURA MUNICIPAL SISTEMA DE LEGISLAÇÃO MUNICIPAL - JFLEGIS. Disponível em: http://www.jflegis. pjf.mg.gov.br. Acesso em 19 abr. 2007.

JUIZ DE FORA (MG). PREFEITURA MUNICIPAL. Plano diretor de desenvolvimento urbano de Juiz de Fora / Diagnóstico. Juiz de Fora, 1996.

JUIZ DE FORA (MG). PREFEITURA MUNICIPAL. Plano diretor de desenvolvimento urbano de Juiz de Fora. Juiz de Fora, 2004. 
LACOSTE, Yves. Para que serve a paisagem? O que é uma bela paisagem? In Boletim Paulista de Geografia, $\mathrm{n}^{\circ}$ 79. Tradução Luis Antonio Bittar Venturi. São Paulo: Associação dos Geógrafos Brasileiros (AGB), 2003. Material didático da disciplina ICA5754-1 Potencialidades e Gestão Ambiental do Instituto de Ciência Ambiental da USP, segundo semestre de 2005.

LEITE, Lesley Gasparini. Plano Diretor: obrigatório por força da Lei Orgânicas Municipal, In. Revista de Direito Público. São Paulo, 1991, ano 24, no 97. In: BRAGA, Roberto. Caderno do Departamento de Planejamento. (Faculdade de Ciências e Tecnologia - UNESP) Presidente Prudente, vol 1, nº 1. Agosto de 1995, pp 15-20). Disponível em: www.rc.unesp.br/igce/planejamento/publicacoes/TextosPDF/RBraga02.pdf.

Acesso em: 05 abr. 2007.

MARTINS, José de Souza - Cultura e educação na roça, encontros e desencontros. In REVISTA USP 64: Dossiê Brasil Rural. São Paulo: Imprensa Oficial do Estado de São Paulo, 2005.

MEDEIROS, Rodrigo. Ambiente \& Sociedade - Vol. IX nº 1. Evolução das tipologias e categorias de áreas protegidas no Brasil. Disponível em: http://www.scielo.br/pdf/asoc/v9n1/a03v9n1.pdf. Acesso em: 03 nov. 2007.

OLIVEIRA-FILHO, A. T. et al. Comparison of the woody flora and soils of six areas of montane semideciduous forest in southern Minas Gerais, Brazil. Edinburgh Journal of Botany, v. 51, p. 355-89, 1994. In: Composição florística e estrutura fitossociológica de uma floresta ripária em Itutinga, MG, e comparação com outras áreas. Revista Brasileira de Botânica, vol.23 no.3 São Paulo: Sept. 2000. Disponível em: http://www. scielo.br/scielo.php?script=sci_arttext\&pid=S0100-84042000000300002\&lng=in\&nrm=iso\&tlng=in. Acesso em: mai. 2006.

PÁDUA, Maria Tereza Jorge. Dúvidas sobre RPPNs. O Eco. Disponível em: http://arruda.rits.org.br/oeco/servlet/newstorm.ns.presentation.Navig ationServlet?publicationCode=6\&pageCode=78\&textCode=23715. Acesso em 26 nov. 2007.

PAISAGEM E AMBIENTE: Ensaios / Universidade de São Paulo, Faculdade de Arquitetura e Urbanismo. Número 16, 2002.

RIZZINI, C. T. Nota prévia sobre a divisão fitogeográfica (florístico-sociológica) do Brasil. Revista Brasileira de Geografia, v. 25, n. 1, p. 3-64, 1963.

SÃO PAULO (ESTADO). Secretaria de Estado da Cultura de São Paulo - Estudo de tombamento da Serra do Mar como Parque Florestal (Processo 
n 20868/79, folhas 1, 2 e3). Material didático da disciplina ICA5754-1 Potencialidades e Gestão Ambiental do Instituto de Ciência Ambiental da USP, segundo semestre de 2005.

SATO, J. 1995. Mata Atlântica: direito ambiental e a legislação. Hemus, Rio de Janeiro. In: BARROS, R.S.M; BISAGGIO, E.L. e BORGES, R.C. Morcegos (mammalia, chiroptera) em fragmentos florestais urbanos no município de Juiz de Fora, Minas Gerais, Sudeste do Brasil. Biota Neotrop. Jan/Abr 2006 vol. 6, no. 1. Disponível em: http://www.scielo.br/pdf/bn/v6n1/v6n1a11.pdf. Acesso em: 04 dez. 2007.

SUERTEGARAY, Dirce Maria Antunes - Espaço geográfico uno e múltiplo. Revista Electrônica de Geografía y Ciências Sociales nº 93. Disponível em: http://www.ub.es/geocrit/sn-93.htm. Acesso em: 10 jun. 2007.

TOURINHO, L. A. M.; PASSOS, E. O código Florestal na Pequena Propriedade Rural: Um Estudo de Caso em Três. Propriedades na Microbacia do Rio Miringuava; 2006. Universidade Estadual de Londrina. Artigos. Ano 4 • Edição número 5 · Dezembro de 2006. Disponível em: http://www. proex.uel.br Acesso em: jan 2008.

UFJF. Anuário Estatístico de Juiz de Fora / 2000. In: JUIZ DE FORA (MG). PREFEITURA MUNICIPAL. Plano diretor de desenvolvimento urbano de Juiz de Fora. Juiz de Fora, 2004.

UFJF. Índices Pluviométricos anuais. Estação Climatológica Principal da UFJF - ECP, 5º DISME (No 83692). In: JUIZ DE FORA (MG). PREFEITURA MUNICIPAL. Plano diretor de desenvolvimento urbano de Juiz de Fora. Juiz de Fora, 2004.

UNESCO, 2003. Subsídios ao zoneamento da APA Gama-Cabeça de Veado e Reserva da Biosfera do Cerrado: Caracterização e Conflitos Socioambientais. Edições Unesco Brasil. Disponível em: http://www.unesdoc.unesco.org/images/0013/001303/130301por.pdf. Acesso em: 29 nov. 2007.

UNESCO, 2007. Reservas da Biosfera. Disponível em: http://www.unesco.org/mab. Acesso em: 26 dez. 2007.

VALVERDE, Orlando. Estudo regional da Zona da Mata, de Minas Gerais. In: Revista Brasileira de Geografia, v. 20, n. 1, p. 3-82, 1958.

VELOSO, H.P.; GOES FILHO, L. Fitogeografia Brasileira, classificação fisionômica. ecológica da vegetação Neotropical. Salvador, IBGE, 1982. In: Câmara Municipal de Juiz de Fora. Disponível em: http://isal.camarajf.mg.gov.br/historia/aspectosfisicos.html. Acesso em: 09 nov. 2007. 
VIANA, V. M. 1990. Biologia e manejo de fragmentos naturais. Pp. 113-118. In: Anais do $6^{\circ}$ Congresso Florestal Brasileiro. Campos do Jordão. São Paulo: EDUSP, 1990.

VILLAÇA, Flávio. Entrevista ao site Vitruvius. Disponível em: http://www.vitruvius.com.br/entrevista. Acesso em: 25 abr. 2007.

VISACRO FILHO, Silvério. Universidade Empresa: Experiência original e bem-sucedida deste tipo de integração coloca Minas Gerais em posição de vanguarda na pesquisa sobre raios e seus efeitos. Disponível em: http://www.revista.fapemig.br/materia.php?id=141. Acesso em: 20 nov. 2006.

WANDERLEY, Maria de Nazaré B. O lugar dos rurais: o meio rural no Brasil moderno. Caxambu, XXI Encontro Anual da Anpocs, outubro de 1997 apud LIMA, Eli Napoleão de. Novas Ruralidades, Novas Identidades. Onde? In: MOREIRA, Roberto José (Org.). Identidades Sociais: ruralidades no Brasil contemporâneo. Rio de Janeiro: DP\&A, 2005.

\section{Bibliografia Recomendada}

Publicações consultadas, mas não mencionadas no texto.

\subsection{Livros}

ARGOLLO, André. Arquitetura do café. São Paulo: Imprensa Oficial SP ; Campinas, SP : Editora Unicamp, 2004.

BATISTA, Rita de Cássia Souza Félix. O negro: trabalho, sobrevivência e conquistas em Juiz de Fora de 1888 a 1930 . Juiz de Fora: Funalfa Edições, 2006. 
BREDARIOL, Celso \& VIEIRA, Lizst. Cidadania e Política Ambiental. Rio de Janeiro: Record, 1998.

CERASI, Maurice. La Lectura del Ambiente. Buenos Aires, Infinito, 1977.

CORRÊA, Roberto L. Espaço, um conceito chave da geografia. In: CASTRO, Iná et al. Geografia: conceitos e temas. Rio de Janeiro: Bertrand Brasil, 1995.

COSTA, L. F. C. C. (Org.) ; MOREIRA, R. J. (Org.) ; BRUNO, R. O. (Org.) . Mundo Rural e Tempo Presente. Rio de Janeiro: Mauad, 1999.

CULLEN, Gordon. A Paisagem Urbana. Edições 70, Lisboa, 1983.

DEL RIO, Vicente. Introdução ao Desenho Urbano no Processo de Planejamento. São Paulo: PINI, 1990.

DITT, Eduardo Humberto. Fragmentos florestais no Pontal do Paranapanema. São Paulo: Annablume/Ipê/IIEB, 2002.

FRANCO, Maria de Assunção Ribeiro. Desenho Ambiental: Uma introdução à arquitetura da paisagem com o paradigma ecológico. São Paulo: Annablume: Fapesp, 1997.

Planejamento Ambiental para a cidade sustentável. São Paulo: Annablume: Fapesp, 2001.

GRAZIANO DA SILVA, José. O novo rural brasileiro. Campinas: FECAMP, 2002.

. A nova dinâmica da agricultura brasileira. Campinas: FECAMP, 1997.

HAESBAERT, Rogério. O Mito da Desterritorialização. Do Fim dos Territórios à Multiterritorialidade. Rio de Janeiro: Bertrand Brasil, 2004.

KOSIK, Karel. Dialética do Concreto. Rio de Janeiro: Paz e Terra, 1976.

LECOCQ MULLER, Nice. Sítios e Sitiantes do Estado de São Paulo. Faculdade de Filosofia Ciências e Letras da USP, 1951. 
LENOBLE, Robert. História da Idéia de Natureza. Lisboa, Edições 70, 2002.

LORENZI, H. Árvores Brasileiras: Manual de Identificação e Cultivo de Plantas Arbóreas do Brasil. Vol. 1 e 2. São Paulo: Editora Nova Odessa, Instituto Plantarum de Estudos da Flora, 1998.

LYNCH, Kevin. A imagem da cidade. São Paulo: Martins Fontes, 1997.

MARTINS, Sebastião Venâncio. Recuperação de matas ciliares.Viçosa: CPT, 2001.

MARTINS, José de Souza. Reforma Agrária: o impossível diálogo. São Paulo: Edusp, 2001.

MCHARG, Ian L. Design with nature. New York: John Wiley \& Sons, 1969.

MORAES, Antônio Carlos Robert. Meio Ambiente \& Ciências Humanas. São Paulo: Hucitec, 1994.

OLIVÉ, Raphael. Guia Estrada Real para Caminhantes: Juiz de Fora - Rio de Janeiro. Belo Horizonte: Editora Estrada Real, 2000.

PIRES, Fernando Tasso Fragoso et al. Fazendas: Solares da Região Cafeeira do Brasil Imperial. Rio de Janeiro: Nova Fronteira, 1999.

ROCHA, Ana Augusta e COSTA, José Pedro de Oliveira (coordenadores). A Reserva da Biosfera da Mata Atlântica e sua Aplicação no Estado de São Paulo. São Paulo: Terra Virgem, Secretaria do Meio Ambiente do Estado de São Paulo, 1998.

SAINT-HILAIRE, Auguste de. Viagem pelas províncias do Rio de Janeiro e Minas Gerais. Belo Horizonte, Itatiaia, 1975.

SANTOS, Márcio. Estradas Reais: Introdução ao estudo dos caminhos do ouro e do diamante no Brasil. Belo Horizonte: Editora Estrada Real, 2001.

SCHELLE, Karl Gottlob. A arte de passear. São Paulo, Martins Fontes, 2001. 
SILVA, José Graziano da. O novo rural brasileiro. Campinas: FECAMP, 2002.

VEIGA, José Eli da. O que é reforma agrária. Coleção Primeiros Passos. São Paulo: Editora Brasiliense, 1981.

YÁZIGI, Eduardo. A alma do lugar: turismo, planejamento e cotidiano. São Paulo: Contexto, 2001.

\subsection{Teses e Dissertações}

BARTALINI, Vladimir. Praças do Metrô: enredo, produção, cenário, atores. Dissertação de mestrado, FAU-USP, 1988.

BENITES, Vinícius de Melo. Caracterização química e espectroscópica da matéria orgânica e suas relações com a gênese de solos da Serra do Brigadeiro, Zona da Mata Mineira. 1998. 123f. Tese (Mestrado em Agronomia) - Universidade Federal de Viçosa, Viçosa, 1998.

COSTA, José Pedro O. Aiuruoca: Matutu e Pedra do Papagaio. Tese de doutorado apresentada à FAUUSP

MORAES, Marilia Britto Rodrigues de. Área de Proteção Ambiental como instrumento de planejamento e gestão: APA Cananéia-Iguape-Peruíbe. Dissertação de mestrado apresentado à FAU-USP, 2000.

\subsection{Outros}

AlBUQUERQUE, Antonio Carlos Carneiro de. Sociedade Civil Ambientalista e as Relações Internacionais. Núcleo de Estudos e Pesquisas Ambientais - Universidade Estadual de Campinas (Nepam/Unicamp) III Encontro Nacional ANPPAS maio de 2006, Brasília, DF. Disponível em: www.anppas.org.br/encontro_anual/ encontro3/arquivos/TA220-28022006-184032.DOC . Acesso em: 20 ago. 2007.

ANAIS DO MUSEU PAULISTA. História e Cultura Material / Universidade de São Paulo, Museu Paulista. v.1 (1922) - v.35 (1987). - São Paulo: 
O Museu, 1922 - 1987; Nova série v.14 nº 1, jan. / jun. 2006.

BORGES, Roberto Cabral. et al. Diagnóstico da fauna silvestre apreendida e recolhida pela Polícia Militar de Meio Ambiente de Juiz de Fora, MG (1998 e 1999). Revista Brasileira de Zoociências, 23-33, julho 2006.

CÂMARA, Ibsen de Gusmão. Plano de ação para a Mata Atlântica. São Paulo: Fundação SOS Mata Atlântica, 1992.

CAMPOS, Gonzaga de. Mapa Florestal. Serviço Geologico e Mineralogico do Brasil. Rio de Janeiro, 1912 Edição Fac-Similar - Secretaria de Estado do Meio Ambiente. São Paulo, 1987.

CASTRO, Paulo Sant`Anna \& LOPES, José Dermeval Saraiva. Recuperação e conservação de nascentes. Viçosa: VÍDEO CPT, 2001.

CENCIG, Mario Oscar. Cadernos da Reserva da Biosfera da Mata Atlântica - 24. Construção do Sistema de Gestão da Reserva da Biosfera da Mata Atlântica.

INSTITUTO CIDADE - Sarandira: memórias de um lugar. CD-ROM. Funalfa Edições. 2006.

LAMPARELLI, Celso Monteiro. Metodologia de pesquisa aplicada à Arquitetura e ao Urbanismo. In: cadernos de pesquisa do LAP / revista de estudos sobre urbanismo, arquitetura e preservação. São Paulo: FAUUSP, set./out.1996.

RANKIN-DE-MERONA, J. M. ; ACKERLY, D. D. Estudos populacionais de árvores em florestas fragmentadas e as implicações para conservação in situ das mesmas na floresta tropical da Amazônia central. Revista IPEF, n. 35, p. 47-59, 1987.

REVISTA USP 64. Dossiê Brasil Rural. São Paulo: Imprensa Oficial do Estado de São Paulo, 2005.

RIBON, R. ; LAMAS, Ivana ; GOMES, Henrique Belfort. Avifauna da Zona da Mata de Minas Gerais -I: municípios de Gioaná e Rio Novo, com alguns registros para Coronel Pacheco e Juiz de Fora. Revista Árvore, Viçosa - MG, v.28, 2004. Disponível em: http://www.scielo.br/pdf/rarv/ v28n2/20994.pdf. Acesso em: 04 dez. 2007.

SANDEVILLE JUNIOR, Euler. Paisagens e métodos. Algumas contribuições para a elaboração de roteiros de estudo da paisagem intra-urbana. 
Paisagens em Debate: revista eletrônica da área de paisagem e Ambiente, FAU USP. Disponível em: http://www.ambiente.arq.br. Acesso em: 28 set. 2006.

SÃo PAUlO (ESTADO). Propostas de Zoneamento Ambiental. Áreas de Proteção Ambiental do Estado de São Paulo, SMA. São Paulo: Série Documento, 1992.

SÃo PAULO (ESTADO). Secretaria do Meio Ambiente. APAs do estado de São Paulo. Coordenadoria de Planejamento Ambiental Estratégico e Educação Ambiental. CD. Maio / 2004. 